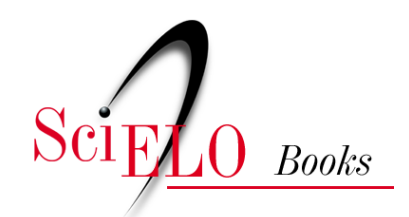

\title{
Educação e sua diversidade
}

\author{
Arlete Ramos dos Santos \\ Julia Maria da Silva Oliveira \\ Lívia Andrade Coelho \\ (org.)
}

SANTOS, A. R., OLIVEIRA, J. M. S., and COELHO, L. A., orgs. Educação e sua diversidade [online]. Ilhéus, BA: EDITUS, 2017, 322 p. Movimentos sociais e educação series, vol. 3. ISBN: 97885-7455-489-1. Available from: doi: 10.7476/9788574554891. Also available in ePUB from: http://books.scielo.org/id/8t823/epub/santos-9788574554891.epub.

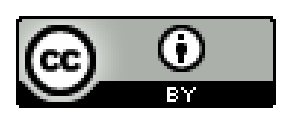

All the contents of this work, except where otherwise noted, is licensed under a Creative Commons Attribution $\underline{4.0 \text { International license. }}$

Todo o conteúdo deste trabalho, exceto quando houver ressalva, é publicado sob a licença Creative Commons Atribição 4.0. 
EDUCACAO e sua diversidade 


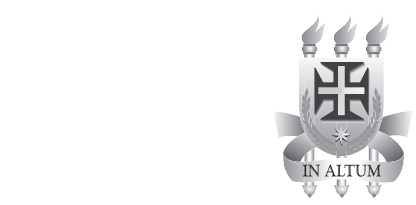

\section{Universidade Estadual de Santa Cruz}

\begin{tabular}{|c|}
\hline $\begin{array}{c}\text { GOVERNO DO ESTADO DA BAHIA } \\
\text { RUI COSTA - GOVERNADOR }\end{array}$ \\
\hline $\begin{array}{l}\text { SECRETARIA DE EDUCAÇÁO } \\
\text { WALTER PiNHEIRO - SECRETÁRIO }\end{array}$ \\
\hline $\begin{array}{c}\text { UNIVERSIDADE ESTADUAL DE SANTA CRUZ } \\
\text { Adélia Maria Carvalho de Melo Pinheiro - Reitor } \\
\text { Evandro Sena Freire - Vice-Reitor }\end{array}$ \\
\hline $\begin{array}{c}\text { DIRETORA DA EDITUS } \\
\text { Rita Virginia Alves Santos Argollo }\end{array}$ \\
\hline Conselho Editorial: \\
\hline $\begin{array}{c}\text { Rita Virginia Alves Santos Argollo - Presidente } \\
\text { Evandro Sena Freire }\end{array}$ \\
\hline Luciana Sedano de Souza \\
\hline Eduardo Lopes Pires \\
\hline Lessí Inês Farias Pinheiro \\
\hline Rita Jaqueline Nogueira Chiapetti \\
\hline Jorge Henrique de Oliveira Sales \\
\hline Guilhardes de Jesus Júnior \\
\hline Alexandra Marselha Siqueira Pitolli \\
\hline Josefa Sonia Pereira da Fonseca \\
\hline Ricardo Matos Santana \\
\hline Maria Luiza Silva Santos \\
\hline Lurdes Bertol Rocha \\
\hline
\end{tabular}




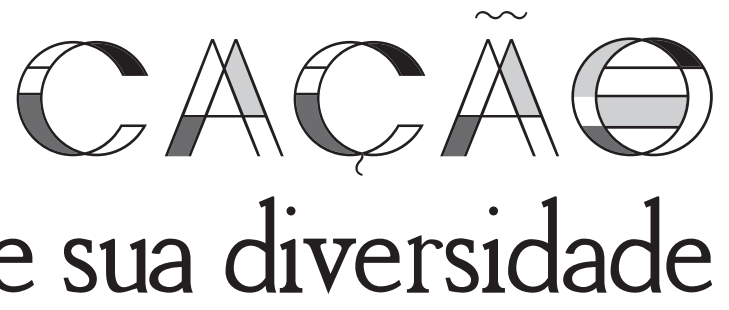

Organizadoras:

Arlete Ramos dos Santos Julia Maria da Silva Oliveira Livia Andrade Coelho

Apoio:

\section{fapesb}

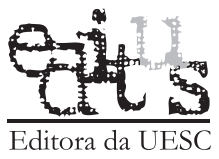


C2017 by Arlete Ramos dos Santos

Julia Maria da Silva Oliveira

Lívia Andrade Coelho

Direitos desta edição reservados à

EDITUS - EDITORA DA UESC

A reprodução náo autorizada desta publicaçáo, por qualquer meio, seja total ou parcial, constitui violaçấo da Lei no 9.610/98.

Depósito legal na Biblioteca Nacional,

conforme Lei no 10.994 , de 14 de dezembro de 2004.

PROJETO GRÁFICO, DIAGRAMAÇÃO E CAPA

A5 editora

REVISÁO

Ana Paula de Amorim

Roberto Santos de Carvalho

Dados Internacionais de Catalogação na Publicação (CIP)

E21 Educação e sua diversidade / Arlete Ramos dos Santos, Julia Maria da Silva Oliveira, Lívia Andrade Coelho (orgs.) - Ilhéus, BA: Editus, 2017.

322 p.: il. - (Movimentos sociais e educação)

Obra publicada com o apoio da Fundação de Amparo à Pesquisa do Estado da Bahia - Fapesb.

Inclui referências.

ISBN: 978-85-7455-437-2

1. Educação multicultural. 2. Educação - Estudo e ensino. 3. Educação - Aspectos sociais. I. Santos, Arlete Ramos dos. II. Oliveira, Julia Maria da Silva. III. Coelho, Lívia Andrade. IV. Título. V. Série.

EDITUS - EDITORA DA UESC

Universidade Estadual de Santa Cruz

Rodovia Jorge Amado, km 16 - 45662-90o - Ilhéus, Bahia, Brasil

Tel.: (73) 3680-5028

www.uesc.br/editora

editus@uesc.br

EDITORA FILIADA À

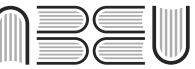

Associação Brasileira

das Editoras Universitárias 


\section{SUMÁRIO}

Apresentação

\section{EIXO 1 \\ EDUCAÇÃO DE JOVENS E ADULTOS}

A prática pedagógica na educação de jovens e adultos: reflexôes a partir de uma experiência pautada na educação popular Paula Cristina S. de Oliveira, Carmem Lúcia Eiterer

"Aqui na universidade não tem esse tipo de aluno não": representações sociais do/a estudante da EJA

Neilton Castro da Cruz, Carmem Lúcia Eiterer.

A luta social ensina: o direito à educação na vida de mulheres e homens sisaleiros

Edite Maria da Silva de Faria 55

\section{EIXO 2 \\ OS JOVENS E O DIREITO À CIDADE}

As "juventudes" vítimas de homicídios: a clivagem etária, raça/cor e sexo na composição das mortes em Pernambuco e na Bahia, em determinado recorte temporal

Rogéria Martins, Paulo Fraga, Elisabeth Murilho

Varas da infância e juventude: uma análise das competências concorrentes e a masculinização judiciária na judicialização dos conflitos na Bahia e em Minas Gerais

Rogéria Martins.

O limpador de para-brisa e a criação do seu direito à cidade

Patricia Jerônimo Sobrinho

Idemburgo Pereira Frazão, Jurema Rosa Lopes 


\section{EIXO 3 \\ DESENVOLVIMENTO REGIONAL, AGROECOLOGIA \\ E SUSTENTABILIDADE}

Via campesina x organismos multilaterais: a luta pela soberania alimentar

Igor Tairone Ramos dos Santos, Arlete Ramos dos Santos....

\section{EIXO 4 EDUCAÇÃO EM ESPAÇOS NÃO ESCOLARES}

A educação nas prisôes como técnica de controle do carcerário: algumas consideraçóes

Fábio Mansano de Mello, Ana Elizabeth Santos Alves.

Formar/açóes para uma identidade de educador social em

espaços não escolares

Arthur Vianna Ferreira.

\section{EIXO 5 \\ A EDUCAÇÃO NAS RELAÇÓES ÉTNICO-RACIAIS}

A cibercultura no combate ao racismo e a discriminação afroreligiosa Luzineide Miranda Borges

O acesso e a permanência de estudantes dos meios populares no ensino superior: a permanência dos negros no curso de Direito da Universidade Estadual do Sudoeste da Bahia (UESB)

Julia Borba Caetité Algarra, Benedito Eugênio 187

\section{EIXO 6 POVOS INDÍGENAS E QUILOMBOLAS: TERRITORIEDADE E EDUCAÇÃO}

A práxis pedagógica dos professores Tupinambás de Olivença, Ilhéus-BA Marcinéia Vieira de Almeida Santos, Emília Peixoto Vieira, Flávia Cristina de Mello 
Relaçóes étnico-raciais: a invisibilidade da criança quilombola na produção acadêmica brasileira

Wesley Santos de Matos, Thiana do Eirado Sena, Benedito Eugênio........223

\section{EIXO 7 \\ MOVIMENTOS SOCIAIS, ASSOCIATIVISMO \\ E SINDICALISMO DOCENTE}

Contributos da educação do campo para formação de sujeitos autônomos: um estudo no assentamento Luis Inácio Lula da Silva Altemar Felberg, Geovani de Jesus Silva....

\section{EIXO 8 \\ MOVIMENTOS SOCIAIS, EDUCAÇÃO E PEDAGOGIAS ALTERNATIVAS NA AMÉRICA LATINA - SUJEITOS E EXPERIÊNCIAS}

Movimentos sociais, educação e diálogo de saberes na América Latina Lia Pinheiro Barbosa.

Políticas públicas educativas: actores, tiempos y contextos Paulina Elena Villasmil Socorro

Joias do Asé - um estudo na perspectiva da etnomatemática José Carlos Dias Ferreira, Rachel de Oliveira, Marcos Rogério Neves. 


\section{APRESENTAÇÃO}

O trabalho docente no contexto da educação exige conhecimento do real, no qual estão inseridas as determinaçóes políticas, culturais, econômicas, sociais, que perpassam o processo educativo, para que a educaçáo aconteça enquanto totalidade, e não de forma fragmentada, sendo a realidade dos sujeitos o ponto de partida e o ponto de chegada. Nesse sentido, destacamos que são várias as identidades que compreendem a diversidade educacional no campo ou na cidade, compostas de sujeitos que aprendem cotidianamente, seja em espaços escolares ou em espaços não escolares, mas que também são compreendidos como educativos, a exemplo das ONG, movimentos sociais, presídios, dentre outros.

Essa diversidade de saberes que o campo educacional exige cada vez mais dos educadores traz para a comunidade acadêmica a responsabilidade de desenvolver estudos e pesquisas que contemplem os fenômenos vividos pelos vários sujeitos que compóem esses processos educativos na atualidade. Nesse sentido, espera-se que os educadores estejam inseridos numa prática educativa que desperte o interesse em buscar a transformação da escola por meio de uma pedagogia emancipatória.

Visando trazer para o debate textos cujas reflexóes se voltam para as análises dos diversos marcos identitários que fortalecem a educação é que surge o livro aqui apresentado, composto por artigos que foram publicados nos Anais do I Congresso Internacional e III Congresso Nacional Movimentos Sociais e Educação realizados na Universidade Estadual de Santa Cruz - UESC, no ano de 2016. O livro está dividido em 8 eixos, a saber:

Eixo 1 - Educação de Jovens e Adultos - este primeiro eixo foi composto por três artigos que se articulam em torno da prática pedagógica na Educação de Jovens e Adultos - EJA, os quais resultaram de pesquisas de mestrado e doutorado. O primeiro texto é fruto de um estudo de caso realizado numa escola pública de Belo Horizonte, que buscou refletir acerca da prática educativa em uma turma de alfabetização da Educação de Jovens e Adultos - EJA. Com base na pesquisa qualitativa, as autoras buscaram respostas para as seguintes questóes: Quais os possíveis fatores referentes à prática educativa poderiam contribuir para que alfabetizandos e alfabetizandas da EJA permaneçam nos estudos?

O segundo texto traz uma investigação que teve como objetivo central identificar egressos/as da EJA no ensino superior público, no estado 
da Bahia, a fim de analisar as condiçóes que concorreram para a entrada e permanência desses sujeitos na vida universitária e teve como campo empírico dois dos 24 Campi da Universidade do Estado da Bahia - UNEB. O terceiro e último texto analisa como se produz o direito à educação no Assentamento Nova Palmares, localizado no município de Conceição do Coité, pertencente ao Território do Sisal da Bahia. A pesquisa procura traçar o perfil dos sujeitos, conhecer suas histórias e trajetórias de vida que, desde crianças, os interrogam e questionam a educação sobre os significados políticos da miséria, da fome, da luta pela terra, pela identidade, pela sua cultura, pela vida e dignidade.

Eixo 2 - Os jovens e o direito à cidade - neste eixo encontramos textos que analisam resultados de pesquisas que versam sobre o papel do espaço público e das manifestaçóes culturais na construção da cidadania dos diferentes coletivos na cidade, bem como a relação entre a educação e a construção das identidades juvenis. O primeiro texto traz um debate acerca da questão da violência, desenvolvido em diferentes pesquisas, apresentando os riscos e vulnerabilidades a que os jovens estáo expostos, notadamente, no que concerne a vitimização por homicídios e por tentativas de homicídios. Além disso, traz reflexóes sobre os diferentes tipos de jovens, denominados pelos autores de "as juventudes". Nesse sentido, observa a temática sobre diversos olhares, que são: suas diferenças, suas similitudes e as desigualdades que se colocam a cada indivíduo ou grupo devido a sua condiçáo de raça, classe ou gênero. $O$ segundo artigo traça o perfil da cultura judiciária em contextos regionais e registra os impactos da aglutinação de várias especialidades jurídicas e a sub-representação feminina na estrutura judiciária que cerca as varas da infância e juventude da realidade brasileira, particularmente da Bahia e de Minas Gerais, com destaque para as comarcas da Zona da Mata mineira.

No terceiro texto, o foco recai sobre os sujeitos que limpam o para-brisa dos carros nos semáforos e nas esquinas do Rio de Janeiro em troca de uma colaboração à vontade do motorista, vitimizados por uma sociedade marcada por processos excludentes, mas que cria o seu próprio direito à cidade.

Eixo 3 - Desenvolvimento regional, agroecologia e sustentabilidade - este eixo é composto por apenas um texto, no qual os autores fazem um estudo sobre o surgimento da Via Campesina e sua relação com a reforma agrária. A metodologia utilizada consta de revisáo de literatura, bem como da realização de pesquisa em relatórios oficiais de organizaçóes internacionais 
como a FAO. Observam-se no texto destaques sobre a história da neoliberalização agrícola, soberania alimentar e segurança alimentar. A partir das reflexóes realizadas, os autores concluíram que a Via Campesina tem se empenhado em diversas lutas ao redor do mundo, com o objetivo de dar mais voz aos camponeses que foram sufocados pelas políticas neoliberais. Além disso, suas açóes têm contribuído para a criaçáo de uma consciência da sociedade civil para outras questóes como a superação da exploração irracional de recursos naturais, da utilização maciça de fertilizantes químicos e de seres vivos transgênicos.

Eixo 4-Educação em espaços não escolares - composto por dois textos, o eixo tem como elemento central a educação fora da instituição escolar. O primeiro texto tem por escopo refletir sobre a funcionalidade da escola no interior das casas correcionais, tendo como pano de fundo a teoria de Michel Foucault acerca da funcionalidade das prisóes em tornar o corpo dos sentenciados politicamente dócil e economicamente útil. Os autores descrevem, em linhas gerais, o cotidiano escolar nas referidas instituiçóes com o fito de apontar suas dificuldades e potencialidades, e sua possível utilidade aos homens privados de liberdade. $\mathrm{O}$ trabalho é finalizado com algumas reflexóes acerca da funcionalidade da escolarização no presídio, bem como sua atividade disciplinadora no interior dessa instituição.

O segundo texto que compóe o eixo demonstra a constituição da figura do educador social no contexto educacional brasileiro desde a organizaçáo de suas práticas educativas para atender as demandas sociais contemporâneas até o entendimento da sociedade brasileira a respeito de sua categoria profissional, seus direitos e suas limitaçóes. Desta forma, o trabalho apresentado busca ressaltar aos formadores de professores e aos seus alunos a importância de compreender a construção deste educador não escolar no cenário educacional brasileiro, fortalecendo os seus processos formativos nas escolas de formação de professores no ensino médio ou superior e valorizando a sua identidade profissional como educador que está em constante reorganização a partir dos serviços prestados à comunidade.

Eixo 5-A educação nas relaçóes étnico-raciais - este eixo discute temáticas acerca dos movimentos sociais que militam a favor dos grupos étnicos "minoritários", observando como estes estáo se posicionando frente ao racismo, a discriminação e a perspectiva didático-pedagógica de educação antirracista. Além disso, debate sobre as políticas afirmativas para populaçôes étnicas e políticas afirmativas específicas em educação, currículo e política curriculares. O eixo contém dois textos, sendo que o primeiro traz 
o resultado de um trabalho desenvolvido pelo Coletivo através da expressão: "A coisa está ficando preta", localizado no sul da Bahia. Trata-se de uma regiáo de pouca ou quase nenhuma visibilidade da cultura afro-brasileira, marcada historicamente pelo silêncio e apagamento da contribuição cultural e histórica dos afro-brasileiros. Segundo a autora, o artigo é resultado da etnografia virtual desenvolvida a partir da análise das publicaçóes realizadas pelo Coletivo durante o ano de 2014 e 2015, em sua página no Facebook.

$\mathrm{O}$ último artigo desse eixo analisa o percurso de escolarizaçáo de estudantes negros dos meios populares no ensino superior. $\mathrm{O}$ trabalho insere-se no Projeto Acesso e a Permanência de Estudantes dos Meios Populares no Ensino Superior. Os dados foram construídos por meio de entrevistas com estudantes negros do curso de Direito (um dos mais antigos e o segundo mais concorrido da Universidade Estadual do Sudoeste da Bahia - UESB). Os estudos realizados apresentam a compreensão dos autores sobre a importância de se (re)pensar sobre a temática em estudo, buscando entender como se dá o processo de educação de estudantes negros até a chegada ao ensino superior, bem como a construção de suas trajetórias escolares.

Eixo 6-Povos indígenas e quilombolas: territoriedade e educação - as reflexóes aqui empreendidas destacam os elementos identitários sobre os povos indígenas e quilombolas, bem como as políticas educacionais que estão inseridas no bojo da luta, observando a cultura, os valores e os saberes desses povos. Com um texto de cada um dos sujeitos estudados, o primeiro artigo discute o resultado de uma pesquisa em andamento sobre a prática pedagógica em uma escola indígena no município de Ilhéus-BA. Os resultados parciais demonstram que os princípios são em parte efetivados na atuação pedagógica Tupinambá, mas ainda acontece de forma tímida e individualizada.

Já o segundo artigo do eixo traz o resultado de uma investigação sobre a criança quilombola na produção acadêmica nacional. Para a análise do material exposto, os autores pesquisaram produçóes acadêmicas que abordam ou se aproximam das categorias: criança quilombola e educaçáo quilombola, nos anais das reuniôes nacionais da Associação Nacional de Pós-Graduação e Pesquisa em Educação - ANPED, no portal Scielo e nos anais do Simpósio Luso - Brasileiro de Estudos da Criança: desafios éticos e metodológicos. Os resultados demonstraram a ausência da temática em foco nesta produção. Por isso, os autores elegeram uma terceira categoria de análise, a invisibilidade, para discutir essa lacuna nas produçôes científicas acerca da temática e do público em questão. 
Eixo 7 - Movimentos sociais, associativismo e sindicalismo docente a discussão em destaque nesse eixo privilegia os movimentos sociais do campo e o direito à educação. Nele encontraremos apenas um texto, o qual traz um estudo realizado em um assentamento do Movimento Sem Terra - MST no sul da Bahia, que buscou compreender de que modo os indicadores de desenvolvimento refletem o grau de autonomia de seus moradores. Os autores concluíram que para potencializar a autonomia, a educação exerce um papel fundamental, no universo e população estudada, efetuando-se na práxis da vida cotidiana, no exercício da cidadania e na participação social, consolidando-se como prática de liberdade.

Eixo 8-Movimentos sociais, educação e pedagogias alternativas na América Latina: sujeitos e experiências - as discussôes aqui propostas têm por objetivo debater experiências de pedagogias alternativas que emergem da práxis educativo-pedagógica dos movimentos sociais contemporâneos na América Latina. O intuito é conhecer alguns elementos teórico-epistêmicos que articulam ditas experiências e sua incidência na proposição de uma prática pedagógica alternativa, bem como na ressignificação do lugar de inscrição do educativo e do pedagógico na conformação de um sujeito educativo. Por outro lado, os autores discutem acerca do que definem como: "pedagogia alternativa" e "sujeito educativo-pedagógico" no processo de construção do conhecimento no campo da Educação e da Pedagogia.

O eixo é composto por três textos, nos quais essas questóes são bem pontuadas, e a discussão inicial, de acordo com a autora, assume a América Latina como ponto de partida, para evocar a trajetória da Educação Popular no continente e seu papel político em momentos cruciais da história recente de nossa região marcados por processos de profundo enrijecimento do cenário político, a propósito do que representaram as ditaduras militares para o Cone Sul. O texto seguinte faz uma discussão ampla sobre a política educacional na América Latina, formulada de acordo com os princípios neoliberais e o impacto que estas políticas têm dado para a consolidação de sistemas educativos seletivos e excludentes. A autora traz, ainda, uma extensa análise sobre o trabalho docente na Venezuela.

$\mathrm{O}$ último texto do eixo traz o recorte de uma pesquisa realizada na comunidade Casa do Boneco - Itacaré-BA, que teve por objetivo responder quais são os diferentes significados das Joias do Asé - na perspectiva da Etnomatemática. Ancorados no Programa de Pesquisa em Etnomatemática do professor Ubiratan D'Ambrosio e nos instrumentos metodológicos da Etnogeometria de Paulus Gerdes, os autores descreveram o 
artefato, identificando elementos de um pensamento geométrico, que os possibilitaram a registrar formas planas (circulares, faixas retangulares e triangulares) e espaciais (curvas em hélice, trançadas e o helicoide), bem como malhas e movimentos na confecção dos colares. Por fim, respondendo à questão de pesquisa e evidenciando a existência de um saber fazer matemático nas práticas daquela comunidade, os autores destacaram elementos de sobrevivência e transcendência nas atividades ancestrais deste povo.

O presente livro vem somar-se à contribuição de pesquisadores(as) que colaboraram no referido congresso e representa esforços dirigidos à luta contra os preconceitos e a discriminação, que atingem grande parte da populaçáo brasileira. Estes(as) pesquisadores(as) com conhecimento da realidade das comunidades indígenas e quilombolas, das relaçóes de gêneros, dos homossexuais, sejam do campo ou da cidade, uniram suas vozes e anseios, expressando na forma de conhecimento científico nos artigos publicados, ou nas lutas cotidianas, as fragilidades e potencialidades da educação como possibilidade de transformação das relaçôes na sociedade hodierna. Acreditamos que os caminhos não devem ser separados nem solitários, mas a especificidade exige abordagens diversas, o importante é náo perder o rumo do diálogo e da troca de experiência.

As Organizadoras 


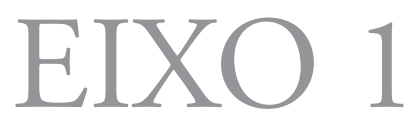

Educação de jovens e adultos 


\title{
A PRÁTICA PEDAGÓGICA NA EDUCAÇÃO DE JOVENS E ADULTOS: REFLEXÓES A PARTIR DE UMA EXPERIÊNCIA PAUTADA NA EDUCAÇÁO POPULAR
}

\author{
Paula Cristina Silva de Oliveira ${ }^{1}$ \\ Carmem Lúcia Eiterer ${ }^{2}$
}

\section{Introdução}

Este artigo é fruto da dissertação de mestrado desenvolvida na linha de pesquisa Educação, Cultura, Movimentos Sociais e Ações Coletivas do Programa de Pós-Graduação em Educação: Conhecimento e Inclusão Social da Universidade Federal de Minas Gerais. Nosso objetivo consistiu em refletir acerca da prática educativa em uma turma de alfabetização da Educação de Jovens e Adultos - EJA. Quais os possíveis fatores referentes à prática educativa poderiam contribuir para que alfabetizandos e alfabetizandas da EJA permaneçam nos estudos?

Tendo como princípio os estudos sobre pesquisa qualitativa, Bogdan e Biklen (1994), realizamos o trabalho de observaçáo e, posteriormente, entrevistas. A investigação foi realizada em uma turma que pertencia ao Projeto de EJA na cidade de Belo Horizonte, (em Minas Gerais, Brasil), que se destacava por respeitar as especificidades de tempo e espaço dos educandos nesta modalidade de ensino.

Desta forma, este artigo está organizado em três partes. Na primeira parte denominada "O dia a dia na sala de aula da EJA", explicitamos as relaçóes entre o referencial teórico e as práticas alfabetizadoras observadas. A seguir, dando sequência ao diálogo, apresentamos a entrevista realizada junto à educadora. Por último, as principais conclusôes a partir deste trabalho.

1 Universidade Federal dos Vales do Jequitinhonha e Mucuri.

E-mail: <paula.ufvjm@gmail.com>.

2 Universidade Federal de Minas Gerais. E-mail: <eiterer@oi.com.br>. 


\section{O dia a dia na sala de aula da EJA}

Como dissemos, a pesquisa de natureza qualitativa pautou-se na observação em sala de aula. Acerca da metodologia científica, Vianna (2007) ressalta que a observaçáo possibilita coletar dados sobre um comportamento não verbal, viabilizando a realização de estudos com maior profundidade acerca do conjunto de indivíduos. Salientando os limites, assim como as estratégias que visam a dar maior credibilidade e confiabilidade a este trabalho, em primeiro lugar aponta que há de se levar em consideração a determinaçáo do grau de influência que a presença do observador pode causar, modificando o contexto e a situação a ser investigada.

Nesse sentido, destacamos que permanecemos por três meses realizando observaçóes numa turma de alfabetização. Verificamos que, em se tratando da temática da permanência nos estudos de alunos/as da EJA, não há como ignorar o lado subjetivo do/a educando/a, seja em relação as suas expectativas e motivaçóes, seja nas relaçóes que o/a educando/a estabelece com os/as colegas ou com o/a educador/a. Há, ainda, os aspectos de caráter mais objetivo, relacionados à prática educativa da professora. Portanto, focalizaremos esses dois vieses na descrição e análise da observaçáo realizada.

No período observado, pudemos notar a presença de vínculos de cooperaçáo e solidariedade entre os/as educandos/as e entre a educadora e os/as educandos/as. Consideramos que essas são marcas de uma relação entre os sujeitos que permitem a acolhida na diversidade. Apresentaremos a seguir situaçóes que ilustram os aspectos presentes nas pesquisas citadas.

Num primeiro episódio que recortamos para exemplificar esta solidariedade por parte da turma, ocorrido na primeira aula observada, um aluno chegou mais tarde, e a professora iria corrigir a atividade passada mais cedo, porém antes ela perguntou aos educandos/as se poderia fazê-lo. Outro aluno afirmou que náo, pois o colega havia acabado de chegar. Notamos que havia no ambiente uma compreensão compartilhada acerca das razóes por trás dos atrasos.

Noutra aula, a filha de um educando, uma criança de três anos, chegou à sala de aula junto com sua avó, que é aluna da turma mais ao final do horário de término da aula. A criança e sua avó foram recebidas com as boas-vindas da educadora e dos outros educandos/as e a criança permaneceu, junto ao pai, na sala. Este acontecimento demonstra a compreensão e solidariedade por parte da turma e da educadora das circunstâncias de vida desses sujeitos. 
No terceiro episódio, as educadoras da escola prepararam uma celebração para comemorar a Páscoa. No dia seguinte à comemoração, alguns estudantes declararam para nós que não gostaram. Em uma conversa informal, a aluna Ondina afirmou que "a aula anda muito devagar" e que "ontem não teve aula". Quando perguntamos o motivo dessas afirmaçôes, ela explicou que no dia anterior havia ocorrido essa celebração da Páscoa, citando, inclusive, um jogo de bingo que aconteceu. Entretanto, nesse mesmo dia, no início da aula, outro aluno, o Sr. Frederico, trouxe um jogo de bingo de presente para a professora, pois no dia anterior, para finalizar a celebração, eles haviam improvisado cartelas e feito o jogo com palavras. Revela-se, desse modo, que a atividade pode ter ganhado um caráter significativo para ele. Destacamos, assim, essa relação de cooperaçáo, por parte do aluno, para com a educadora.

No primeiro mês de observação, um grupo de 13 educandos frequentava as aulas. Entretanto, do mês de abril em diante alguns alunos/as, até então "desconhecidos/as", "começaram a comparecer". No dia 13 de abril, a chegada da aluna Mariana chamou nossa atenção. Desde o mês anterior, estávamos acompanhando a turma e não a conhecíamos, não havia registro de presença da educanda nesse período. Ela chegou à sala de aula e foi recepcionada com muita alegria pela professora. A aluna declarou que não esperava que a educadora a aceitasse de volta na escola. Mariana relatou que não estava frequentando a aula, porque estava trabalhando até mais tarde. Chegava a casa e tinha de preparar o jantar, de modo que ficava muito tarde para ir à escola. A situação vivenciada por Mariana ilustra a constatação de Alves (2006) ao verificar que, ao ingressarem num curso de EJA, as mulheres se deparam com o desafio de frequentarem as aulas regularmente, conciliando o tempo entre o "trabalho fora de casa, as tarefas domésticas e os cuidados com seu grupo familiar" (ALVES, 2006, p. 125). O acolhimento da educadora demonstra mais uma vez respeito às necessidades e ao tempo dos educandos. Entendendo-os como adultos que faltam à escola não por evasão ou desinteresse, mas premidos por necessidades concretas do dia a dia.

A partir deste episódio, e de outros momentos acompanhados, notamos que há um movimento por parte da turma e da educadora de solidariedade, reconhecimento das dificuldades reais em relação à frequência desses estudantes, que vão ao encontro do que está registrado no Projeto Político Pedagógico da Instituição. Muitos educandos/as dessa turma se ausentam sim, durante o ano letivo, devido a situaçóes vivenciadas no mundo 
adulto ligadas ao mundo do trabalho, ao cuidado da família, às urgências da vida cotidiana, conforme salienta Da Cruz (2011). Entretanto, voltam e sáo acolhidos, incentivados a permanecer pela educadora, como no caso de Mariana e, também, Rosane (uma educanda que estava grávida).

Reafirmamos, portanto, o aspecto relacional, que caracterizamos como possível fator interno ao ato educativo, de cunho subjetivo. As palavras de Freire (2006) refletem a relação dialógica à qual nos referimos:

Desta maneira, o educador já não é o que apenas educa, mas o que, enquanto educa, é educado, em diálogo com o educando que, ao ser educado, também educa. Ambos, assim, se tornam sujeitos do processo em que crescem juntos e em que os "argumentos da autoridade" já não valem. Em que, para ser-se, funcionalmente, autoridade, se necessita de estar sendo com as liberdades e não contra elas (FREIRE, 2006, p. 79).

Encontramos este aspecto relacional destacado também nas pesquisas de Maranhão (1998), que cita a reconstituição da identidade de sujeitos no processo de alfabetização; Parenti (2000), que trata dos laços de solidariedade entre os sujeitos envolvidos na prática educativa; Chamorro (2002), que aborda a relação de amizade entre os colegas; Correia, Souza e Bicalho (2003), acerca das relaçóes que se estabelecem entre os sujeitos educandos e educador; Campos (2003), que versa sobre a formação significativa para o educando; Souza (2005), que considera as relaçóes de afetividade; Mileto (2009), que analisa as redes de sociabilidade e os vínculos de solidariedade e cooperação estabelecidos; Cunha (2009), que avalia a relaçáo com o outro e com o conhecimento na escola e Bastos (2011), que faz referência à socialização na escola.

Com relação à prática educativa, algumas atividades comuns nas aulas da professora Rosimeire demonstravam preocupação com a contextualização constante do trabalho: relembrar junto aos educandos/as o que foi estudado no dia anterior e retomar conteúdos já vistos quando estes apareciam novamente. No primeiro dia de aula observada, por exemplo, a educadora Rosimeire fez a leitura do Termo de Consentimento Livre e Esclarecido - TCLE desta pesquisa para os/as alunos/as, mas antes explicou a eles que aquele era um tipo de texto diferente dos outros que a turma já havia trabalhado, como receita e bilhetes, retomando as características destes. Vemos nessa atitude uma demonstração de preocupação com o desenvolvimento do letramento dos alunos. 
No decorrer da observação, a educadora demonstrava atenção e paciência, especialmente com os alunos que tinham mais dificuldade, como Idalina, que se encontrava numa fase inicial do processo de alfabetização. Rosimeire procurava passar de carteira em carteira, observando o desempenho dos alunos/as e fazendo intervençôes individualizadas.

Dificuldades relacionadas à prática pedagógica também foram expostas por Rosimeire. A educadora afirmou haver, naquele contexto, escassez de materiais específicos para a EJA. Os livros distribuídos pelo Programa Nacional do Livro Didático para a Alfabetização de Jovens e Adultos PNLA não estavam disponíveis para serem usados no início do ano letivo, em fevereiro. Apenas no dia 3 de maio, os exemplares chegaram às mãos da educadora e ela pôde entregá-los aos educandos.

Segundo Rosimeire, os recursos didático-pedagógicos eram poucos, mas ela improvisava e os criava com os recursos disponíveis. Rosimeire dizia trabalhar com folders e panfletos distribuídos em supermercados, pelo posto de saúde etc. No decorrer do período de observação, a nosso ver, a professora se mostrou empenhada em buscar alternativas. Em uma das aulas observadas, reaproveitou a parte de trás de um cartaz de propaganda para registrar e exibir a letra de uma música a ser trabalhada em sala de aula.

A prática de bingo de palavras também era comum no final de suas aulas. O bingo de palavras consistia na entrega de meia folha de papel, tamanho A4, em que os alunos deviam riscar dois traços na horizontal e dois na vertical, formando uma tabela com nove quadrados. A professora deixava registradas no quadro as palavras trabalhadas naquele dia de aula. Dentre as palavras dessa lista, os educandos deviam escolher e escrever uma palavra em cada quadrado. Rosimeire sorteava aleatoriamente as palavras. Ganhava quem completasse toda a tabela primeiro. Cabe ressaltar que nessa atividade eram exploradas, predominantemente, habilidades referentes à decifração, ou seja, à identificação de palavras.

Rosimeire se preocupava em trazer atividades diferenciadas para D. Idalina, que estava em fase inicial de alfabetização. No dia 14 de abril, a professora entregou um caderno sem pauta à aluna, pois ela estava se preocupando muito com as pautas, desmanchando a escrita inúmeras vezes para refazê-la de modo "correto". Idalina estava aprendendo a escrita do seu primeiro nome, em letra caixa-alta. Em outra ocasião, Rosimeire levou uma atividade diferenciada, que consistia em oferecer à aluna algumas imagens (entre elas a de uma bola e a de uma boneca) para que a educanda relacionasse o nome às imagens, enquanto os demais alunos faziam outra 
atividade voltada à leitura e à cópia de um pequeno texto. Ou seja, além de diagnosticar as diferentes etapas em que cada um se encontrava, a professora demonstrava o cuidado na produção de atividades adequadas a elas.

Algumas dificuldades, acarretadas pelo viés administrativo, foram descritas pela educadora em conversas informais. A primeira dificuldade apontada advinha do trabalho em duas salas diferentes ao mesmo tempo. Em um dos dias de observação, a educadora foi até à turma de certificação corrigir a atividade deixada anteriormente e relatou que surgiu uma discussáo importante naquela sala que teve de ser interrompida, porque ela tinha de retornar à turma de alfabetizaçáo. A segunda dificuldade foi exposta à pesquisadora, e também aos alunos, um dia antes da única paralisação a que as educadoras aderiram durante a observaçáo que empreendemos na escola. A justificativa dada aos alunos em razão de paralisar as atividades escolares por um dia foi o excesso de trabalho das docentes. Havia apenas duas professoras para planejar e lecionar em três turmas e elas assim como os demais educadores de turmas externas do Projeto EJA/BH respondiam também por parte do registro de secretaria, atualizando diários e realizando matrículas.

Para melhor apreensão das situaçóes observadas durante as aulas, optamos por destacá-las, abarcando duas vertentes. Serão listadas as situaçôes relacionadas à aquisição/domínio e ao uso social do código escrito, em Língua Portuguesa e Matemática. Neste sentido, cabe destacar que

a capacidade de compreender, utilizar e refletir sobre a informação escrita é vista como um contínuo que abrange desde o conhecimento rudimentar de elementos da linguagem escrita até operaçóes cognitivas complexas que envolvem a integração de informaçóes textuais e dessas com os conhecimentos e visão de mundo aportados pelo leitor (RIBEIRO; FONSECA, 2010, p. 148).

Em algumas ocasióes, a professora Rosimeire "mesclava" atividades de Língua Portuguesa com atividades de Matemática. Assim, a perspectiva dos dois domínios do alfabetismo3, citados por Ribeiro e Fonseca (2010),

3 Neste artigo, as autoras associam o termo alfabetismo "à capacidade de compreender, utilizar e refletir sobre informaçóes contidas em materiais escritos de uso corrente - impressos, manuscritos ou eletrônicos -, para alcançar objetivos, ampliar conhecimentos e participar da sociedade" (RIBEIRO; FONSECA, 2010, p. 148). 
podem nos ajudar na compreensão das atividades propostas:

Para fins de estudos específicos e de produção de indicaçóes para ações pedagógicas, é possível distinguir, nesse amplo universo a que se denomina alfabetismo, pelo menos dois domínios: as capacidades de processamento de informaçôes principalmente verbais - que compóem o domínio aqui denominado letramento - e as capacidades de processamento de informações quantitativas, que envolvem noções e operaçóes matemáticas, associadas ao domínio denominado numeramento (RIBEIRO; FONSECA, 2010, p. 149).

Estamos inseridos em uma cultura grafocêntrica, mas nossa sociedade também é marcada pela preeminência do recurso ao quantitativo,

[...] para a descrição e controle dos fenômenos, de modo que as práticas matemáticas valorizadas socialmente apoiam-se nas tecnologias e/ou nos princípios da cultura escrita, que, por sua vez, se deixa permear pelos códigos e critérios da quantificação (RIBEIRO; FONSECA, 2010, p. 149).

Em suma, a partir dos dados que emergem da observação, notamos que, de um lado, a educadora e os/as educandos/as articulam aspectos de cunho subjetivo, como o estabelecimento de laços de solidariedade e companheirismo. No que tange à prática pedagógica, verificamos que há a busca, por parte da educadora, da explicitação das intençóes educativas, a atenção à diversidade, às características e às especificidades dos/as estudantes.

De outro lado, vemos características também de uma prática educativa de um ensino de cunho mais tradicional, mais centrado na professora, conforme lista Mizukami (1986). Com intervençóes da educadora, seleção de ideias organizadas logicamente e cópias de modelos verificados durante a observação.

\section{Sobre a educadora Rosimeire}

Rosimeire é natural de Melo Viana, pequena cidade próximo a Raul Soares, Minas Gerais, Brasil, tem 46 anos, autodeclara-se branca, é divorciada e tem duas filhas adultas, sendo que uma está concluindo o ensino 
superior, e a outra concluiu o ensino médio. Seu pai estudou até a antiga quarta série do ensino fundamental, sua mãe até a segunda. Sua formação inicial de nível médio é em magistério e graduou-se em Geografia/História em uma instituição da rede privada, sob a forma presencial, na cidade de Formiga/MG4. Cursou duas especializaçóes, em Educaçáo Inclusiva e em Psicopedagogia. A entrevista, de acordo com a preferência da educadora, aconteceu numa pequena sala na escola onde, atualmente, ela ocupa o cargo de vice-diretora.

A professora possui uma longa trajetória profissional, anterior ao seu ingresso no Projeto EJA/BH, como se poderá conferir a seguir, ligada a práticas de alfabetizaçáo e ao trabalho com alunos com dificuldade de aprendizagem. Iniciou o magistério alfabetizando crianças na rede estadual de ensino. Depois tomou posse na carreira docente na rede municipal de Belo Horizonte. Ela declarou ter afinidade com a proposta da Escola Plural5. Trabalhou com "turmas projeto" no ensino fundamental até decidir participar do Projeto EJA/BH:

Educadora: Formei no magistério... na época era magistério, e, assim... no ano que eu formei eu já comecei num projeto do Estado que era pra atender os alunos de seis anos [...] me chamaram pra Prefeitura e, este ano, em março, completo 20 anos de Prefeitura. Antes da Escola Plural, porque assim que eu entrei veio a Escola Plural, então já tinha aquelas ideias, né? Então, eu sofria muito de a gente levar esses alunos até o final do ano, na primeira série, era primeira série há 20 anos, então, a gente levava os meninos até o final do ano, naquele processo de alfabetização. Quando chegava no final do ano, você via que, mais dois ou três meses, eles iam embora, deslanchavam e iam passar pra série seguinte, o segundo ano. Quando veio o

4 O perfil da educadora coincide com o perfil apresentado por Gatti e Barreto (2009), em pesquisa nacional; a docência pode significar mobilidade social, superando os pais em escolarização.

5 "A Escola Plural não é apenas uma proposta pedagógica, nem se confunde com uma simples mudança de metodologias. Trata-se, antes de tudo, de um projeto político que se diferencia de outras propostas consideradas modernas. Principalmente daquelas que procuram diminuir os custos da educaçáo, na medida em que tem como finalidade a formação do aluno inserido no coletivo das transformaçôes culturais e sociais." Disponível em: <http://www. pbh.gov.br/smed/cape/outras/public/plural.htm>. Acesso em: 13 out. 2011. 
projeto da Escola Plural, pelo projeto pela Prefeitura de Belo Horizonte, eu me sentia extremamente satisfeita, porque os meninos teriam mais da escola do que aqueles três meses pela frente. E o trabalho da gente é um trabalho diferente, do que a gente precisava fazer. Respeitou-se o tempo do aluno. Daí pra cá, eu só, eu só peguei as salas... as chamadas Projetos da Prefeitura, porque a sala... assim, as salas projetos... e os professores não queriam pegar. 'Ah, a Rosi pega! A Rosi pega!' Aí eu pegava a turma e ficava um ano, dois anos com a turma [...] (Transcrição da fala da professora).

Há alguns indícios na fala da educadora que nos fazem crer que esta tenha um perfil diferenciado no coletivo da escola onde atuava. Vejamos:

Pesquisadora: $\mathrm{O}$ que é essa sala projeto?

Educadora: A sala projeto é onde os meninos que tinham mais dificuldades, de cada turma [...] Então, assim, por exemplo, a primeira série: tirava-se os meninos da primeira série que ficavam com nota baixa e colocava nessa turma. Chamava projeto. Hoje, não faz mais isso. [...] tinha gente na escola que falava a turma Bomba, panela de pressão, porque ficava os meninos que tinham dificuldade, dificuldade constante de aprendizagem, com uma defasagem muito grande de conteúdo e, também, os mais levados. Mas era sorteio e eu só pegava a Turma Projeto.

A seguir a professora relata seu ingresso na EJA/BH e sua relação com esses novos educandos, seu desejo de experimentar novas dimensóes do trabalho docente:

[...] E... e... este ano eu completo 20 anos de Prefeitura, tem mais 6 de Estado, entáo vou pra 27 anos de profissáo, e no Projeto EJA/BH eu fui convidada várias vezes pra participar e relutava. Queria trabalhar, mas queria continuar com a turma que tava na escola. E, por 3 anos, eu me neguei ao EJA/BH pra continuar com a turma. Um dia eu fui lá fazer a entrevista, eu falei: "não, agora eu vou". Larguei a turma, em fevereiro, e peguei o EJA BH. E... e.... nesse período que eu fiquei na Escola Municipal trabalhando no Projeto EJA/BH foi muito interessante, porque... Você vai chegando ao final de carreira, você já fez tudo dentro de uma escola. Então, a professora dentro 
da sala de aula, as pessoas que eles são, os alunos que eles são, com aquela ânsia de aprender e você vai pra... né? Contribuir e eles querem aprender, isso também chama atenção. Eles tão lá pra aprender. E... você é capaz também, com aquela... com aquele... ali dentro daquela sala, você é capaz de mudar várias vidas. Isso é muito importante pra gente, principalmente pra gente que está aqui, tâo acostumada com o ensino fundamental. O Projeto EJA/BH é novidade mesmo... é... pra todos que estão, né?... de professor... Você se sente tão valorizado pelos alunos, e os alunos se sentem valorizados, porque... né? Você tem paciência pra ensinar... e cada aluno é tão diferente, cada aluno tem um desejo, ânsia... todos diferente. Isso é muito bom, a gente se sentir valorizado como professor. E lá você realmente você sente que você é um professor, que você tá ali pra ajudar, pra contribuir [...].

Rosimeire é admitida no Projeto EJA/BH, projeto que esteve em vigor durante algum tempo em Belo Horizonte, por meio da seleção feita na Secretaria Municipal de Educação da Prefeitura de Belo Horizonte SMED/PBH:

A Prefeitura estava com esse projeto há mais ou menos dois ou três anos. Quando eu cheguei com esse projeto, foi seleção, né? Que eles falam Equipe Pedagógica do Projeto EJA/BH, pra fazer a seleçáo e enviar professor pros locais onde tinha turma, que era $\mathrm{BH}$ inteira. Tipo: shoppings, igrejas evangélicas, centros comunitários, né? E algumas turmas eram turmas dentro da escola, que funcionava dentro da escola que era o ensino regular, que tinha, né? Já estava aí dentro dos últimos estudos, no ensino regular noturno, e foi transformado em EJA. E... é... passava por uma seleção na SMED e a gente era encaminhada pra esses locais e começava o trabalho da formação na SMED. E tinha que estudar, porque... a gente náo tinha claro o que que a gente ia encontrar, o que que a gente ia priorizar pra ensinar [...].

Rosimeire nos narra um dia de trabalho no Projeto, atentando para aspectos relacionados à especificidade desses sujeitos, jovens, adultos e idosos, destacando a importância que assume o tempo na sala de aula de EJA:

Pesquisadora: Você poderia descrever um dia de trabalho na EJA? $\mathrm{Na}$ EJA/BH? Qual que era a rotina... 
Educadora: Completamente diferente da escola regular, né? Primeiro porque a gente não tem um horário fixo previsto pra entrar. A gente tem o horário do professor chegar. Hoje, é 6:30 $\mathrm{h}$, mas o aluno náo tem hora pra chegar. $\mathrm{O}$ aluno chega 6:30 h, 6:40 h, 7 h... e ele também não tem aquele tempo fixo pra ele ficar na sala de aula. Ele chega, ele trabalha, e ele chega a hora que ele dá conta de chegar e fica o tempo que ele der conta também... na... na... sala de aula. E, como a sala, a sala de aula tem, desde alfabetização até a última etapa lá do Projeto EJA/BH. Dentro do projeto a gente tem afiliaçáo às etapas. E... como a sala tem vários alunos de vários níveis, a gente conta, também, com a ajuda dos colegas, um ajudando o outro. $E$ os assuntos, às vezes, também acontecem na própria aula, né? Eu planejo uma aula e não dou conta de terminar aquela aula, porque o assunto vai rendendo... e de um assunto vai passando pro outro, e tem que ter um pouquinho dessa amarração. Eu tenho um projeto que eu planejo pra aula, que às vezes foge e vai pro assunto de interesse deles mesmos. E aquele tempo náo existe, tem o tempo pra cada aluno. Tem que ter as etapas e... respeitando o tempo de cada um, o limite de cada um, a vontade de cada um.

Durante a entrevista, fica evidente, em várias ocasiôes, a atenção da educadora ao direito dos estudantes à educação, anteriormente negado na infância, às condiçóes de tempo do educando/a que tem família e trabalha, a consideração dos conhecimentos prévios desses educandos/as, além da importância do trabalho pedagógico aliado às vivências dos estudantes:

O Projeto EJA/BH vem pra atender as pessoas que... que... gostariam, né? Na época que precisavam estar na escola regular de aprendizado, saíram, saíram da escola por n motivos. Porque tinham que trabalhar, porque tinham que cuidar dos irmãos em casa, a mãe morreu, o pai morreu e ele tinha que trabalhar... porque não teve acesso à escola. Então, é um resgate mesmo, uma dívida com este aluno. Hoje, ele vai pra escola, vai estudar, né? É um direito que ele tem que foi negado a ele, no tempo normal, quando ele era criança, e que agora ele pode resgatar dentro desse Projeto EJA/BH. E que ele é atendido é, no horário, né? Que é um horário em que ele pode encontrar a turma, né? Ele pode aproveitar lá a Matemática de uma turma ou ele pode estar na frente no Português, 
ou ele pode aproveitar uma outra turma. É... o conhecimento dele é valorizado a partir do que ele sabe. $O$ saber dele é que vai direcionar o trabalho feito por nós, professores.

Acima encontramos no discurso da docente marcas de uma compreensão sociocultural do aluno da EJA. A professora continua demonstrando compreender as contingências que se interpóem no cotidiano da prática educativa com adultos e a importância de açóes comprometidas com a expansão do repertório desse aluno:

[...] $\mathbf{O}$ aluno tem liberdade de chegar e sair. E o engraçado, quando eles têm essa liberdade de chegar e sair, os alunos raramente eles vão embora mais cedo, pelo contrário, eles querem ficar, né?, além do horário. E se você deixar eles vão ficando além do horário mesmo. Então, eles procuram chegar no horário e procuram não sair fora do horário, apesar do portáo estar aberto. E eles estão sempre abertos, né?, a fazer uma atividade diferenciada. Um passeio, uma excursáo, um trabalho extraclasse, um trabalho do bairro. Ele tem uma receptividade maior pra você fazer com eles uma excursão, e a surpresa da gente que... que eles moram, né?, há muito tempo em $\mathrm{BH}$, eles não conheciam a Lagoa da Pampulha. Então, o dia que nós fomos à Lagoa da Pampulha eu falei: 'Gente, eu preciso proporcionar mais isso pros alunos'. Os nossos alunos, eles não conheciam a Lagoa da Pampulha. Eles não conheciam o Museu... da Lagoa. Aí, eu... a gente... o planejamento da gente tomou outro olhar, né? "Vamos planejar aqui como que a gente vai fazer pra gente fazer com que esses alunos conheçam Belo Horizonte, onde eles moram?” E... e... e... o mais engraçado, quando você começa a pensar na Lagoa, é que você pensa no bairro.

Sua prática se dirige também a pensar o lugar que esses sujeitos ocupam na cidade e sua relação com esse espaço. Permite a reflexão sobre as complexas redes que constituem a trama do tecido social:

O dia que nós fizemos a excursão pelo bairro, que eles passaram na beirada do córrego que eles passavam todos os dias pra ir trabalhar, eles passavam ali, mas eles não conseguiam olhar para o córrego, de tanto que ele estava poluído, o tanto que eles estavam, né?, assim, porque eles estavam poluindo aquele 
córrego. Então, a partir do momento que nós fizemos a excursáo pelo bairro, eles começaram a ver o tanto que o córrego estava poluído e quais as açóes, né? Que eles podiam fazer pra tornar aquele ambiente melhor pra eles mesmos. Eles ficaram assustados com a poluição dele. E apontavam, né? 'Fulano de tal veio aqui e jogou isso! $\mathrm{O}$ carroceiro veio aqui de dia e jogou isso!' Eles apontaram os problemas e quem, né?, levaram os problemas. E, também, as difíceis soluçôes. Porque para os carroceiros não jogarem mais material lá, o lixo, o entulho, eles tinham que ter um outro trabalho, porque aquele trabalho, aquele tipo ali... de jogar o lixo ali... é o trabalho que sustentava a eles e as famílias deles. Então, a partir de um passeio pelo bairro, de uma passeata pelo bairro, eles viram os problemas, né? Tentaram achar soluções, mas ainda pensaram no outro, que estava ganhando o pão de cada dia fazendo aquilo ali com a natureza. Foi, assim, fantástico esse passeio pelo bairro, porque foi um lugar que eles passavam todos os dias, né? Olhavam e não viam.

Em relação ao trabalho pedagógico desenvolvido, a professora dá ênfase à etapa de planejamento, que inclui momentos individuais e coletivos:

Pesquisadora: Como que se organiza então o trabalho pedagógico, as reuniōes de formação? Como que elas acontecem? Que temas que são tratados nessas reuniōes de formação?

Educadora: O Projeto Pedagógico ele tem duas etapas: ele tem a etapa da escola, dos professores, né? De dois em dois meses, eles se reúnem pra fazer o planejamento para a turma, tem local que tem uma turma, tem local que tem mais de uma turma, então, quando tem mais de uma turma, o planejamento é feito pelos professores, todos no horário, antes dos alunos chegarem. E tem outro, também, trabalho pedagógico que é voltado para os coordenadores que têm também, o estudo, né? A leitura de textos sobre EJA. E também o trabalho pedagógico é organizado pelo próprio aluno. A gente usa os interesses do aluno, de acordo com as especificidades de cada etapa.

Atentando para a diversidade manifesta nos níveis de aprendizagem dos/as educandos/as, a docente fala do papel do erro no aprendizado e da avaliação processual: 
Pesquisadora: E a avaliação?

Educadora: A avaliação é um tema muito difícil, assim, pra gente, até hoje. Porque a gente não tem uma medida pra avaliar, né? Nas turmas trabalhadas, a gente avalia no dia a dia. $\mathrm{E}$, às vezes, o aluno nem está pronto pra isso, pra você estar fazendo uma avaliação. Mas eles cobram nossa avaliação, né? "Ah, você tem tanto." Aí, a gente sente necessidade de fazer, mas não pra preparar para passar pro ano seguinte. A gente faz essa avaliação mais pra ele ver o tanto que ele está melhorando, não pra gente ter uma nota e com essa nota colocar numa fase seguinte. É mais processual, ao longo do ano, você ver assim, "Acertou? Seu erro. Você errou aqui. E você tem que acertar, você tem direito de corrigir. Você está aqui para isso." Então, a gente tem sempre essa preocupação de falar isso pro aluno, de falar pra ele. Porque ele tem medo de errar, mas ele tem que tentar.

Tratando especificamente sobre a alfabetização nessa modalidade educativa, a educadora distingue o cuidado com a diversidade de saberes no trecho que segue:

Pesquisadora: Que tipo de atividade de alfabetização você costumava propor para turma?

Educadora: Era muito direcionado por eles mesmo, né? Porque a turma tinha aluno que estavam iniciando o processo de alfabetizaçáo, no meio do processo de alfabetização, e alunos que já vinham, já sabiam interpretar. Então, pra não ficar tão diferenciado, às vezes uma atividade, eu diferenciava só a forma, né? De dar essa atividade. Alunos que já sabiam, assim, a procurar a letra, né? Palavras. Alunos que já liam e interpretavam. Outro que já conseguia transcrever um texto, ele ia transcrever. E como a turma era muito... uma turma muito diferenciada, a gente tem que contar com a ajuda dos colegas. É um ajudando o outro. Enquanto você ensinava, você aprende muito mais.

No trecho a seguir, no qual Rosimeire relata um depoimento de uma aluna, aparece a compreensão da extensão de sua ação educativa para além da sala de aula:

Tanto que eu tive uma aluna, ela chama Geneci, primeira aluna que eu trabalhei lá do Projeto, ela falava assim: 'Professora, 
hoje eu não estou como o dia que eu entrei aqui, hoje eu sei muito mais e consegui me posicionar perante até o meu patrão. Hoje, eu sei falar com alguém se eu não gostei, sabe? Eu não levo pra frente se eu náo gostar. E eu vou professora, passar por todas as etapas, vou pro segundo grau e vou pra faculdade. E o tempo perdido pra mim não interessa, o que interessa é de agora pra frente'.

Vemos que, de acordo com o estudo de Costa e Oliveira (2011), o aprendiz precisa de dois passaportes para inserir-se e permanecer nesse mundo que privilegia a cultura escrita. São eles, o domínio da tecnologia de escrita, obtido pelo processo de alfabetização e o domínio de competências de uso dessa tecnologia, adquirido por meio do processo de letramento. Sobre a prática pedagógica da educadora, podemos afirmar, por meio da observação e da entrevista, que a professora Rosimeire trabalhava na perspectiva mencionada por essas autoras: privilegia atividades que contribuem para que o/a educando/a desenvolva habilidades relacionadas ao sistema alfabético e ortográfico, assim como proporciona momentos em que os/as estudantes possam fazer o uso da leitura e da escrita em diferentes situaçóes e contextos.

Em consonância com o trabalho de Albuquerque, Morais e Ferreira (2010) ao se referirem sobre a importância de trabalhar com o Sistema de Escrita Alfabético - SEA na EJA, Leal e Morais (2010) reafirmam que para planejar boas situaçóes didáticas é importante saber de modo organizado e explícito como se organiza o objeto de ensino - o SEA - e os modos como os educandos se apropriam desse saber. Neste sentido, Leal e Morais (2010) apresentam uma classificação que abrange atividades de alfabetização e sugerem que em sala de aula sejam promovidas situaçóes em que os diferentes conhecimentos possam emergir e ser foco de atenção. Notamos atividades propostas pela educadora que contemplam a categorização proposta pelos autores:

Atividades que buscam familiarização com as letras;

Atividades que objetivam a construção de palavras estáveis;

Atividades de reflexão fonológica;

Atividades de composição e decomposição de palavras escritas;

Atividades de comparação de palavras escritas;

Atividades de escrita de palavras através do preenchimento de lacunas; 
Atividades de permuta, inserçâo ou retirada de letras e sílabas para formação de novas palavras;

Atividades de ordenação de letras e sílabas;

Atividades de leitura de palavras;

Atividades de escrita de palavras (LEAL; MORAIS, 2010, p. 131).

Além disso, a educadora demonstrou, no decorrer da entrevista, estar atenta às demandas específicas do público da EJA, tais como as citadas por Simóes e Eiterer (2006): organização de currículo apropriado, produção de material didático adequado às necessidades educacionais desse público e elaboração de estratégias de ensino diferenciadas, conforme a etapa de desenvolvimento do educando. Esses indícios parecem concorrer, portanto, para delinear um conjunto de fatores que chamamos internos à prática pedagógica que pretendíamos localizar.

\section{Consideraçóes finais}

Como vimos em linhas anteriores, em relação à prática pedagógica em uma turma de alfabetizaçáo de EJA, notamos a presença de vínculos de cooperação e solidariedade, entre os próprios educandos/as e entre eles/ as e a educadora. $\mathrm{O}$ aprendizado da língua escrita, além de trazer marcas de um ensino mais tradicional e, ao mesmo tempo, com atividades que enfocam o sistema de escrita alfabético e ortográfico, conforme sugerem Leal e Morais (2010), aproximava-se do desafio diário citado por Simóes e Eiterer (2006).

Acrescentando elementos à análise da prática da educadora, de acordo com Simóes e Eiterer (2006), o/a educador/a de EJA tem um desafio cotidiano que abarca, de um lado, concepçóes interacionistas de ensino-aprendizagem que ele traz e, de outro, as concepçóes tradicionais que o/a aluno/a busca, além das dificuldades que envolvem a construção de novos conhecimentos: "de um lado as aquisiçóes do conhecimento científico que o educador traz e, de outro, o conhecimento construído a partir das vivências que o educando traz" (SIMÓES; EITERER, 2006, p. 172).

A educadora, assim como está registrado no Projeto Político Pedagógico da escola, parece estar atenta ao último aspecto citado pelas autoras, que busca levar em consideração as vivências dos educandos. 
É realizado um trabalho de mediação, por parte da educadora, conciliando expectativas com práticas que são mais adequadas aos estudantes da turma. Neste sentido, Barreto e Barreto (2005) afirmam que a disparidade entre a visáo que o aluno da EJA tem do que seja a escola e uma educação que efetivamente sirva a esse aluno pode gerar conflitos, ocasionando, inclusive, casos de desistência do curso. Portanto, de acordo com os autores, os educadores da EJA, assim como a educadora de nossa investigação, têm obtido mais sucesso quando apresentam a seus alunos/as a escola que eles imaginavam encontrar:

Qual o problema de as carteiras estarem dispostas em forma tradicional nos primeiros dias? [...]

Que mal existe em que o aluno tente copiar o que o professor escreve? Principalmente quando é possível ligar o copiado ao seu significado ou criar situaçóes onde o objeto da cópia tem um sentido especial para quem o realiza: seu próprio nome, nome dos seus filhos...

[...] Compete ao educador desafiar o aluno para outras atividades além daquelas que ele espera da escola (BARRETO; BARRETO, 2005, p. 68).

Percebemos na fala da educadora nuances relacionadas à especificidade desta modalidade de ensino, conforme Arroyo (2005):

Temos de reconhecer que muitas experiências de EJA acumularam uma herança riquíssima na compreensão dessa pluralidade de processos, tempos e espaços formadores. Aprenderam metodologias que dialogam com esses outros tempos. Incorporaram nos currículos dimensóes humanas, saberes e conhecimentos que forçaram a estreiteza e rigidez das grades escolares curriculares.

Tudo isso foi possível porque essas propostas ousadas estavam fora das grades, sem o fantasma da verificação de aproveitamento dos estudos, da sequenciação curricular seriada, do cumprimento de cargas horárias por disciplina, área etc. As lógicas foram outras (ARROYO, 2005, p. 228).

Identificamos, portanto, por parte da docente, uma ação pedagógica mediada pela conciliação de certas expectativas que, normalmente, os educandos da EJA já trazem consigo, com um viés mais tradicional, e, ao 
mesmo tempo, aliada a uma prática emancipatória ligada à valorização das vivências dos estudantes. Para este processo, aparenta ser importante, como afirmou a educadora, o modo pelo qual é organizada a dinâmica de formação de professores, a permitir momentos individuais e coletivos em que a docente podia compartilhar com seus pares a diversidade dos níveis de aprendizagem de seus alunos e alunas, além de aspectos relacionados às especificidades deste público. Dessa forma, as concepçóes de alfabetização e letramento na Educaçáo de Jovens e Adultos da educadora, a nosso ver, estavam em consonância com o que estava expresso na Proposta Pedagógica da escola, retratando a preocupação com a aquisiçáo do código escrito em meio a situaçóes presentes de uso no cotidiano dos estudantes. O direito dos estudantes à educação negado na infância, o respeito às condiçôes de tempo do educando/a que tem família e trabalha, a consideração dos conhecimentos prévios desses educandos/as, além da importância do trabalho pedagógico aliado às vivências dos estudantes são elementos importantes que vimos serem considerados nesta prática educativa em EJA.

\section{Referências}

ALBUQUERQUE, E.; MORAIS, A.; FERREIRA, A. A relação entre alfabetização e letramento na Educação de Jovens e Adultos: questóes conceituais e seus reflexos nas práticas de ensino e nos livros didáticos. In: LEAL, T.; ALBUQUERQUE, E.; MORAIS, A. (Orgs.). Alfabetizar letrando na EJA: fundamentos teóricos e propostas didáticas. Belo Horizonte: Autêntica, 2010.

ALVES, F. Mulheres trabalhadoras, sim. Aluna por que náo? Estudo sobre gênero, trabalho e educação na Bahia. Dissertação (Mestrado em Educação) Faculdade de Educação, Universidade Católica de Brasília, Brasília, 2006.

ARROYO, M. Educaçáo de Jovens e Adultos: um campo de direitos e de responsabilidade pública. In: GIOVANETT, M., GOMES, N. E SOARES, L. (Orgs.). Diálogos na Educaçáo de Jovens e Adultos. Belo Horizonte: Autêntica, 2005.

BARRETO, V.; BARRETO J. C. Um sonho que não serve ao sonhador. In: VOVIO, C.; IRELAND, T.(Orgs.). Construção coletiva: contribuiçóes à educação de jovens e adultos. Brasília: UNESCO, MEC, RAAAB, 2005.

BASTOS, L. Traçando metas, vencendo desafios: experiências escolares de mulheres egressas da EJA. Dissertação (Mestrado em Educação) - Faculdade de 
Educação, Universidade Federal de Minas Gerais, Belo Horizonte, 2011.

BOGDAN, R.; BIKLEN, S. Investigaçáo Qualitativa em Educaçáo: uma introdução à teoria e aos métodos. Porto: Porto, 1994.

CAMPOS, E. A Infrequência dos alunos adultos trabalhadores, em processo de alfabetizaçáo, na Universidade Federal de Minas Gerais. Dissertação (Mestrado em Educação) - Faculdade de Educação, Universidade Federal de Minas Gerais, Belo Horizonte, 2003.

CORREIA, L.; SOUZA, M.; BICALHO, M. Os significados que jovens e adultos atribuem à experiência escolar. In: REUNIÃO ANUAL DA ANPED, 26, 2003, Caxambu. Anais..., Caxambu, 2003.

COSTA, C.; OLIVEIRA, P. Alfabetização, letramento e Educação de Jovens e Adultos. In: SOARES, LEÔNCIO (Org.). Educação de Jovens e Adultos: o que revelam as pesquisas. Belo Horizonte: Autêntica, 2011, p. 115-148.

CUNHA, L. Uma interpretaçáo filosófico-antropológica das experiências escolares de jovens e adultos na EJA. Dissertação (Mestrado em Educação) Faculdade de Educação, Universidade Federal de Minas Gerais, Belo Horizonte, 2009.

CHAMORRO, C. Alegria na escola noturna: um sonho possível. Dissertação (Mestrado em Educação) - Programa de Pós-Graduação em Educação, Universidade do Vale do Rio dos Sinos, São Leopoldo, 2002.

DA CRUZ, N. Trajetórias ininterruptas de estudantes da EJA no ensino fundamental: casos pouco prováveis. Dissertação (Mestrado em Educação) Faculdade de Educação, Universidade Federal de Minas Gerais, Belo Horizonte, 2011.

FREIRE, P. Pedagogia do Oprimido. 45. ed. São Paulo: Paz e Terra, 2006.

GATTI, B.; BARRETO, E. Professores do Brasil: impasses e desafios. Brasília: UNESCO, 2009.

GIOVANETTI, M. A formação de educadores de EJA: o legado da Educação Popular. In: SOARES, L.; GIOVANETTI, M.; GOMES, N. (Orgs.). Diálogos na educaçáo de jovens e adultos. Belo Horizonte: Autêntica, 2005.

LEAL, T.; MORAIS, A. O ensino dos princípios do sistema alfabético e de suas convençóes. In: LEAL, T.; ALBUQUERQUE, E.; MORAIS, A. Alfabetizar na EJA: fundamentos teóricos e propostas didáticas. Belo Horizonte: Autêntica, 2010. 
MARANHÃO, H. Analfabeto: Ser e não ser. In: REUNIÃO ANUAL DA

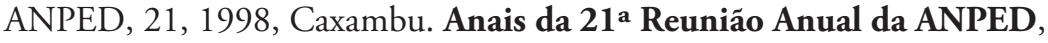
Caxambu, 1998.

MILETO, L. "No mesmo barco, um ajuda o outro a náo desistir": estratégias e trajetórias de permanência na Educação de Jovens e Adultos. Dissertação (Mestrado em Educação) - Faculdade de Educaçáo, Universidade Federal Fluminense, Niterói, 2009.

MIZUKAMI, M. Ensino: as abordagens do processo. São Paulo: EPU, 1986.

PARENTI, M. Trabalhadores da Construção civil e a experiência escolar: significados construídos. In: REUNIÂO ANUAL DA ANPED, 23, 2000, Caxambu. Anais..., Caxambu, 2000.

RIBEIRO, V.; FONSECA, M. Matriz de referência para medição do alfabetismo de jovens e adultos nos domínios do letramento e do numeramento. In:

SOARES, L. et al. (Orgs). Convergências e tensóes no campo da formaçáo e do trabalho docente. Belo Horizonte: Autêntica, 2010.

SIMÓES, A.; EITERER, C. A didática na EJA: contribuiçóes da epistemologia de Gastón Bachelard. In: SOARES, L.; GIOVANETTI, M.; GOMES, N.

Diálogos na educaçáo de jovens e adultos. 2. ed. Belo Horizonte: Autêntica, 2006.

SOARES, L.; VIEIRA, M. Trajetórias de formaçãa: contribuiçôes da educação popular à configuração das práticas de Educação de Jovens e Adultos. In: SOARES, L.; SILVA, I. (Orgs.). Sujeitos da educaçáo e processos de sociabilidade: os sentidos da experiência. Belo Horizonte: Autêntica, 2009.

SOUZA, M. Construindo significados: a alfabetização de jovens e adultos para trabalhadores. In: REUNIÃO ANUAL DA ANPED, 28, 2005, Caxambu. Anais..., Caxambu, 2005.

VIANNA, H. Pesquisa em Educação: a observação. Brasília: Plano, 2007. 


\title{
"AQUI NA UNIVERSIDADE NÁO TEM ESSE TIPO DE ALUNO NÂO”: REPRESENTAÇÓES SOCIAIS DO/A ESTUDANTE DA EJA
}

\author{
Neilton Castro da Cruz ${ }^{1}$ \\ Carmem Lúcia Eiterer ${ }^{2}$
}

\section{Consideraçóes iniciais}

Este trabalho é parte das reflexóes que o exercício da pesquisa de doutorado, ainda em desenvolvimento junto ao Programa de Pós-Graduação da Faculdade de Educação, da Universidade Federal de Minas Gerais - FaE/UFMG, nos propiciou. A citada investigação tem como objetivo central identificar egressos/as da EJA no ensino superior público no estado da Bahia, a fim de analisar as condiçôes que concorreram para a inserção e, sobretudo, permanência desses sujeitos na vida universitária.

A pesquisa tomou como campo empírico dois dos 24 campi da Universidade do Estado da Bahia - UNEB. A escolha pela citada instituição, tendo em vista a existência, ainda, de outras três IES $^{3}$, pode ser justificada pelo fato de ter sido a $\mathrm{UNEB}^{4}$ a primeira das instituiçóes

1 Professor da Rede Municipal de Educação de Porto Seguro.

E-mail: <neiltoncastro@yahoo.com.br>.

2 Professora adjunta da Faculdade de Educação da UFMG e pesquisadora do NEJA. E-mail: <eiterercarmem@gmail.com>.

3 Universidade do Sudoeste da Bahia - UESB, da Universidade Estadual de Santa Cruz UESC e da Universidade Estadual de Feira de Santana - UEFS pode ser justificada pelo fato de ter sido a UNEB.

4 "No Brasil, as Açốes Afirmativas alcançaram maior visibilidade recentemente com a instituiçáo do sistema de cotas nas universidades públicas, notadamente após a Universidade do Estado da Bahia - UNEB, em julho de 2002, ter aprovado, no Conselho Universitário - CONSU, a histórica Resolução de reservar 40\% das vagas, no processo seletivo, aos estudantes negros que estudaram em escolas públicas. A decisão da UNEB repercutiu intensamente nas comunidades acadêmicas em todo o Brasil e abriu caminho para uma agressiva disputa política e filosófica quanto à pertinência de tais políticas fora dos muros das universidades, inclusive dentro do Congresso Nacional” (SILVA, 2010, p. 50). 
públicas do estado da Bahia e também do Brasil a implantar Políticas de Açôes Afirmativas.

São oito pessoas os sujeitos que compóem o quadro de colaboradores/as, sendo cinco do sexo feminino e três do masculino. Todas matriculadas em quatro diferentes cursos de licenciatura no modelo presencial, a saber: História, Letras, Matemática e Pedagogia.

A identificação dos sujeitos ocorreu a partir do contato direto com a universidade, no qual se constatou a presença de 22 pessoas de potencial interesse. Diante do que nos apresentou o campo empírico, fizemos a opção metodológica por entrevistar dois/duas estudantes de cada curso.

A proposta de pesquisa ora mencionada, no nosso entendimento, assentou-se no entrecruzamento do debate sobre políticas públicas de natureza afirmativa e a temática que aborda a longevidade e/ou o sucesso escolar. Os estudos que têm buscado compreender as trajetórias longevas, nesse caso, o acesso de pessoas de camadas populares ao ensino superior, afirmam que tal fenômeno dependeria, sobremaneira, do capital cultural possuído pelos indivíduos (NOGUEIRA; NOGUEIRA, 2004)5. Carece ressaltar que, tomando como base as buscas realizadas no Banco de Teses da Coordenação de Aperfeiçoamento de Pessoal de Nível Superior (CAPES) e da Biblioteca Digital Brasileira de Teses e Dissertaçóes (BDTD), é possível afirmar que a problemática denominada "trajetórias longevas e/ou de sucesso escolar" entre egressos/as da EJA se apresenta como lacuna no campo de investigaçáo, já que nenhum trabalho foi identificado.6

Estamos certos de que os dados que sustentam essa reflexão não dão base para generalizaçóes, contudo, consideramos que o exercício ao qual nos propomos realizar nesse ensaio pode nos ajudar a compreender certas posiçóes quanto aos sujeitos que compóem a Educação de Jovens e Adultos. Nesse sentido, este artigo é, na realidade, uma tentativa de refletir sobre a forma como o/a egresso/a da EJA é visto, por colega de trabalho, do curso de pós-graduação (mestrado e doutorado), por professores/as

5 Vale destacar que não conseguimos encontrar, entre as pesquisas que investigaram a temática da longevidade e/ou sucesso escolar, estudos que tenham tomado o/a egresso/a da EJA como sujeito empírico.

6 As buscas foram realizadas utilizando palavras-chave: "A inserçâo de Egresso da EJA no Ensino Superior"; "Egresso da EJA na Universidade"; "Egresso da Educação de Jovens e Adultos no Ensino Superior"; "Trajetória Longevas de Egresso da EJA". 
e alunos/as da universidade onde realizamos a coleta de dados, quando se cogita a possibilidade desse sujeito vir a se tornar estudante de curso universitário em uma universidade pública, no estado da Bahia. Nessa medida, o exercício reflexivo ao qual nos propomos a realizar tem como objetivo central compreender e esclarecer as razóes que podem justificar a posição de suspeição, por parte de algumas pessoas com as quais conversamos, quanto a possibilidade de estudantes com experiência na EJA estarem matriculados/as em cursos da Universidade do Estado da Bahia - UNEB. Em muitas situaçóes ficou evidente que falar do nosso interesse de pesquisa promovia, com certa recorrência, comentários do tipo: "você acha que vai encontrar egressos/as da EJA no ensino superior público?" Ou ainda: "Aqui não tem esse tipo de aluno não!"

É válido ressaltar que o esforço aqui investido é, na realidade, uma tentativa de problematizar as suspeitas que estão em torno do debate sobre a inserção do/a egresso/a da EJA na universidade, sobretudo a pública.

\section{Representaçóes Sociais}

Com o objetivo de fundamentar a discussão ora proposta nos apropriamos do conceito de Representaçóes Sociais ${ }^{7}$, de autoria de Moscovici. O referido autor construiu sua base teórica a partir do conceito de representaçáo coletiva, proposto por Durkheim. Argumenta que este se referia a uma classe muito genérica de fenômenos psíquicos e sociais, englobando entre eles os referentes à ciência, aos mitos e à ideologia, sem a preocupação de explicar os processos que dariam origem a essa pluralidade de modos de organização do pensamento. Além disso, de acordo com o autor, a concepção de representação coletiva era bastante estática, o que correspondia à permanência de fenômenos incoerentes aos estudos das

\footnotetext{
A Teoria das Representaçóes Sociais surge na França, em 1961, com a publicação do livro intitulado A psicanálise: sua imagem e seu público, obra do psicólogo romeno naturalizado francês, Serge Moscovici. O escritor foi o primeiro a introduzir o conceito de representação na psicologia social contemporânea. Sua teoria se apresenta como uma forma sociológica de Psicologia Social. Contudo, o próprio autor destaca que o conceito de Representação Social ou Coletivo teria nascido na Sociologia e na Antropologia, por meio de Durkheim e de Lévi-Bruhl (MOSCOVICI, 2007).
} 
sociedades contemporâneas, que se caracterizam pela multiplicidade de sistemas políticos, religiosos, filosóficos e artísticos e pela rapidez na circulação das representaçôes (GUARESCHI; JOVCHELOVITCH, 2007; FARR, 2007).

Para Alves-Mazzotti (1994, p. 62):

A noção de representação social proposta por Moscovici corresponde à busca desta especificidade, através da elaboração de um conceito verdadeiramente psicossocial, na medida em que procura dialetizar as relaçóes entre indivíduo e sociedade, afastando-se igualmente da visão sociologizante de Durkheim e da perspectiva psicologizante da Psicologia Social da época.

Moscovici insiste em dizer: "É óbvio que o conceito de representaçôes sociais chegou até nós vindo de Durkheim. Mas nós temos uma visão diferente dele - ou, de qualquer modo, a psicologia social deve considerá-lo de um ângulo diferente - de como o faz a sociologia" (MOSCOVICI, 2003, p. 45). O problema específico dessa área, continua o autor, é o estudo de como e porque as pessoas partilham o conhecimento e, dessa maneira, constituem sua realidade comum. Assim, afirma ele, as Representaçóes Sociais possuem natureza "convencional" e "prescritiva".

É convencional no sentido de que elas

[...] convencionalizam os objetos, pessoas ou acontecimentos que encontram. Elas lhes dão uma forma definitiva, os localizam em uma determinada categoria e gradualmente os colocam como modelo de um determinado tipo, distinto e partilhado por um determinado grupo (MOSCOVICI, 2003, p. 34).

Para o autor,

[...] impressionisticamente, cada um de nós está obviamente cercado tanto individualmente como coletivamente, por palavras, ideias e imagens que penetram nossos olhos, nossos ouvidos e nossa mente, quer queiramos quer não (MOSCOVICI, 2003, p. 33).

É prescritiva, no sentido de que elas se impóem sobre nós com uma força irresistível. De acordo com Moscovici (2003, p. 36), a tal força é, na 
realidade, a "combinação de uma estrutura que está presente antes mesmo que nós comecemos a pensar e de uma tradição que decreta o que deve ser pensado". Para o autor, qualquer criança que nasça hoje em qualquer país ocidental estará submetida a uma estrutura da psicanálise. Tal fato ocorreria por meio dos gestos da mãe ou de seu médico, das histórias em quadrinhos, dos textos escolares, da relaçáo com os colegas de aula etc. Sem falar dos jornais, dos discursos políticos que terá de ouvir e dos filmes que assistirá.

As representações sociais são histórias na sua essência e influenciam o desenvolvimento do indivíduo desde a primeira infância, desde o dia em que a mãe, com todas as suas imagens e conceitos começa a ficar preocupada com seu bebê (MOSCOVICI, 2003, p. 108).

Nesse sentido, afirma o autor:

Nenhuma mente está livre dos efeitos de condicionamentos anteriores que lhes são impostos por suas representaçóes, linguagem ou cultura. Nós pensamos através de uma linguagem; nós organizamos nossos pensamentos, de acordo com um sistema que está condicionado, tanto por nossas representaçôes, como por nossa cultura. Nós vemos apenas o que as condiçóes subjacentes nos permitem ver e nós permanecemos inconscientes dessas convençóes (MOSCOVICI, 2003, p. 35).

A Representação Social, além de ser estudada como campo estruturado, também pode ser focalizada como núcleo estruturante, o qual é abordado como campo semântico, ou seja, como um conjunto de significados isolados por meio de diferentes métodos de associaçóes de palavras. Trata-se de identificar as estruturas elementares que constituem o cerne do sistema da representação em torno das quais ele se organiza, qual seja: um sistema constituído pelos seus elementos centrais e periféricos.

De acordo com Abric (2000), toda representação social está organizada em torno de um núcleo central e um sistema periférico. $\mathrm{O}$ núcleo central está relacionado à memória coletiva, dando significação, consistência e permanência à representação, sendo, portanto, estável e resistente a mudanças. Esse núcleo é composto pelos elementos estáveis ou mais permanentes da representação social, sendo estes de natureza normativa e 
funcional. Quanto ao sistema periférico, este é responsável pela atualização e contextualização da representação.

Para Moscovici (2003), a psicologia social aborda as representaçóes sociais no âmbito do seu campo, do seu objeto de estudo, a relação indivíduo-sociedade, e de um interesse pela cognição, embora não situado no paradigma clássico da psicologia. Ela reflete sobre como os indivíduos, os grupos, os sujeitos sociais, constroem seu conhecimento a partir da sua inscrição social, cultural etc., por um lado, e por outro, como a sociedade se dá a conhecer e constrói esse conhecimento com os indivíduos.

As representaçôes sociais são entidades quase tangíveis. Elas circulam, se entrecruzam e se cristalizam continuamente, através duma palavra, dum gesto ou duma reunião, em nosso mundo cotidiano. Elas impregnam a maioria de nossas relaçôes estabelecidas, os objetos que nós produzimos ou consumimos ou as comunicações que nós estabelecemos. Nós sabemos que elas correspondem, dum lado, à substância simbólica que entra na sua elaboração e, por outro lado, a prática específica que produz essa substância, do mesmo modo como a ciência ou o mito correspondem a uma prática científica ou mítica (MOSCOVICI, 2003, p. 35).

Wagner (2000) salienta que a representação social é sempre uma unidade do que as pessoas pensam e do modo como fazem, sendo, então, mais do que uma imagem estática de um objeto na mente das pessoas. Ela compreende, também, seu comportamento e a prática interativa de um grupo.

Cada cultura possui um meio muito particular de representaçáo social, de modo que ela tem sua própria forma ou instrumento para transformar suas representaçôes em realidade. Nós particularizamos indiscriminadamente as classes sociais, os sentimentos, os poderes, além de personificar a cultura. Moscovici (2003) adverte que as representaçóes sempre possuem duas faces, que são interdependentes, como as faces de uma folha de papel: a face icônica e a face simbólica. Para o autor, a representaçáo é igual à imagem/significação; em outras palavras, a representação iguala toda imagem a uma ideia e toda ideia a uma imagem e, sob certos aspectos, ela é específica de nossa sociedade.

O sucesso de uma representação é que garante a ela o poder de controlar a realidade de hoje através da de ontem, e da possível continuidade que ela possa ter. 
Se é verdade que nós classificamos e julgamos as pessoas e coisas comparando-os a um protótipo, então nós, inevitavelmente, estamos inclinados a perceber e a selecionar aquelas características que são mais representativas desse protótipo (MOSCOVICI, 2003, p. 64).

Em nossa sociedade, está claro que a cor da pele, o gênero e a origem social mobilizam representaçóes sociais sobre o sujeito, em especial para os/as que têm assumido a ideia de que tais questóes definem o papel e, sobretudo, o lugar de cada um/a na sociedade. "Uma representação é construída de um conjunto de informaçóes, de crenças, de opinióes e de atitudes a propósito de um objeto social" (ABRIC, 2000, p. 30).

É importante destacarmos que, para Moscovici (2003), o ser humano é um ser pensante, que formula questóes e busca respostas, ao mesmo tempo em que compartilha realidades por ele representadas. Nessa medi$\mathrm{da}$, o autor enfatiza "[...] que pessoas e grupos, longe de serem receptores passivos, pensam por si mesmos, produzem e comunicam incessantemente suas próprias e específicas representaçôes que eles mesmos colocam" (MOSCOVICI, 2003, p. 45). O autor argumenta que não é possível escapar das representaçóes sociais, mas, enquanto sujeitos ativos e críticos, no decurso do tempo, as representaçóes podem ganhar novos contornos e ser modificadas, a partir das açóes desenvolvidas socialmente. Dito de outra forma, pessoas e grupos criam representaçôes no decurso da comunicação e da cooperação.

Representaçôes, obviamente, não são criadas por um indivíduo isoladamente. Uma vez criadas, contudo, elas adquirem uma vida própria, circulam, se encontram, se atraem e se repelem e dão oportunidade ao nascimento de outras representaçóes, enquanto velhas representaçóes morrem (MOSCOVICI, 2003, p. 41).

\section{Representaçóes Sociais do/a estudante da EJA}

Nosso objetivo nessa parte do texto é apontar elementos que podem nos ajudar a compreender as razóes que estão por trás da imagem construída em torno do/a estudante que frequenta e/ou frequentou a Educação de Jovens e Adultos. 
Cogitamos, a partir do que nos aponta Moscovici (2003), que, possivelmente, a forma como a sociedade enxerga e localiza o estudante da EJA esteja atrelada ao fato de que nos últimos anos o acesso à escola tenha ampliado, mas poucas mudanças ocorreram quanto ao problema relacionado à qualidade. Porém, ainda cabe ser compreendido o porquê do analfabetismo não ter "tido a mesma atenção de outras modalidades de ensino. A taxa de analfabetismo no Brasil está praticamente estagnada" (GADOTTI, 2013, p. 13).

Outro fator que nos ajuda na compreensão da questáo diz respeito ao fato de a Educação de Jovens e Adultos, historicamente, ter sido vinculada ao processo de alfabetização, por razóes óbvias: o analfabetismo continua sendo um problema grave que o Brasil não conseguiu superar. "O analfabetismo é uma ofensa ao direito de cidadania: é como negar o direito humano à comida, à liberdade, o direito a não ser torturado" (GADOTTI, 2013, p. 13). Podemos acrescentar ainda o caso de a EJA ter sido, ao longo do tempo, espaço propício à descontinuidade do processo de escolarizaçáo. Para Di Pierro (2005, p. 1120):

A identidade dos sujeitos não foi construída com base em características psicológicas, cognitivas, de gênero, de faixa etária ou outras, mas em torno de representaçóes sociais enraizadas, por um lado, no estigma que recai sobre os analfabetos em sociedades letradas, e por outro, em uma relativa homogeneidade sociocultural dos educandos, conferida pela condição de camponeses ou imigrantes rurais e trabalhadores com pouca qualificação.

"A preocupaçáo com o analfabetismo no Brasil tem sido tema de discussão desde a Colônia e o Império. Mas é no início do século XX, principalmente após 1940, que passa a ser visto como um problema nacional" (FÁVERO, 2009, p. 9). O debate em torno da garantia de educação às pessoas adultas, desde o início, tinha clara a concepçáo de que a condição de analfabeto/a, de uma parte significativa da populaçáo, impedia o acesso a outros direitos, como, por exemplo, o político, já que nesse momento histórico o/a analfabeto/a náo tinha direito a votar. "Por isso, a luta pelo direito à educação não está separada pela luta dos demais direitos", argumenta Gadotti (2013, p. 26). Fávero (2009) também assinala que, apesar do foco ser a alfabetização, principalmente pelo expressivo contingente de pessoas analfabetas acima dos 15 anos, havia ainda o entendimento de que a oferta deveria atender outros níveis da escolarizaçáo. 
A educação de adultos, desde os primórdios foi vista como uma ação ampliada, não restrita à alfabetização, mesmo que a ação da Campanha de Educação de Adolescentes e Adultos - CEAA tenha a ela se restringido.

[...] Mesmo partindo de um conceito extremamente limitado de analfabeto trabalhando com um conceito restrito de analfabetismo/alfabetização, as campanhas significaram um movimento positivo de Estado e da sociedade brasileira, no atendimento às necessidades educacionais da população adolescente, jovem e adulta mais pobre (FÁVERO, 2009, p. 12).

$\mathrm{Na}$ atualidade, o percentual de brasileiros/as analfabetos/as maiores de 15 anos ultrapassa os $8 \%$, que são, portanto, quase 15 milhóes de pessoas analfabetas. Essa realidade conserva a alfabetização como referência da EJA, como um dos processos a ela previstos, enquanto modalidade da Educaçáo Básica. Para Gadotti (2013, p. 21), "precisamos tornar a alfabetização de adultos parte integrante do sistema educativo e superar a atual falta de profissionalização da área".

Se hoje algumas pessoas com as quais conversamos demonstraram desconfiança sobre a probabilidade do egresso/a da EJA entrar na universidade, isso não é uma característica apenas dos tempos atuais. Fávero (2009) garante que desde a década de 1940 o referido grupo já era visto por esse viés, o da suspeiçáo de suas capacidades, como a intelectual, por exemplo. Nesse período histórico, "a leitura de artigos e relatórios da época revela um conceito preconceituoso do analfabeto, principalmente das áreas rurais: incompetente, marginal, culturalmente inferior" (p. 10).

A suspeição já mencionada, segundo Galvão e Di Pierro (2013), na agenda política, à educação de pessoas jovens e adultas foi reservado lugar secundário. Um exemplo que pode ser citado diz respeito ao fato de a alfabetização não ter sido colocada, historicamente, como direito, mas como "caridade". Ainda segundo as autoras: "[...] o analfabeto é visto como uma criança que precisa da ajuda de alguém para tirá-lo das trevas. Ou alguém que precisa de carta de alforria, porque o analfabetismo é visto como uma espécie de escravidáo" (p. 52).

Ainda segundo as autoras, esse tipo de representação, com suas diversas variaçóes, é recorrente na mídia, no discurso político, e ao mesmo tempo em que nutre o preconceito, promove a baixa autoestima dos/as não alfabetizados/as que, mesmo vivendo dignamente, acabam por incorporar o discurso da inferioridade a eles e a elas atribuído (GALVÁO; DI PIERRO, 2013). 
Nas relações sociais há um lugar guardado para os/as que não tiveram oportunidades de vivenciar a escolarização por um período mais esticado. Essa localização em muito contribui para que ocorra a discriminação dos/ as jovens, dos/as adultos/as e, principalmente, dos/as idosos/as. Quanto ao problema do analfabetismo, Fávero (2009) garante que, depois de mais de 50 anos de experiência, as "campanhas e movimentos de massa não resolveram e não resolveráo o problema do analfabetismo da população jovem e adulta” (FÁVERO, 2009, p. 19).

Ireland (2009) argumenta que a EJA é vista por muitos como uma forma de alfabetizar quem náo teve oportunidade de estudar na infância ou aqueles que, por algum motivo, tiveram de abandonar a escola, o que, em sua opinião, seria um equívoco. Para o autor, a alfabetizaçáo é uma parte fundamental, mas não é a única.

Assim como a alfabetização, as altas taxas de interrupção da trajetória escolar de estudantes da EJA têm sido também elemento de debate e pesquisa. Em geral, esse fenômeno tem ocorrido com mais força ainda nos primeiros anos da experiência.

A interrupção dos estudos possui natureza diversa, como, por exemplo, a necessidade de trabalhar e/ou de procurar emprego. Os dados da Pesquisa Nacional por Amostra de Domicílio (PNAD), publicados em maio de 2009, reafirmam tal dificuldade. Segundo o relatório, entre os/ as estudantes que efetuaram matrículas em 2007 ou em anos anteriores, apenas 4,3\% dos jovens e adultos conseguiram concluir o primeiro segmento do fundamental ( $1^{\mathrm{a}}$ a $4^{\mathrm{a}}$ série), $15,1 \%$, o segundo segmento (de $5^{\mathrm{a}}$ a $8^{\mathrm{a}}$ série), e $37,9 \%$, o ensino médio (do $1^{\mathrm{o}}$ ao $3^{\circ}$ ano), sem interrupção. Segundo a mesma pesquisa, os principais motivos para a não conclusão foram:

O horário das aulas não era compatível com o horário de trabalho ou de procurar trabalho $(27,9 \%)$; o horário das aulas não era compatível com o horário dos afazeres domésticos $(13,6 \%)$; tinha dificuldade de acompanhar o curso $(13,6 \%)$; não havia curso próximo à residência $(5,5 \%)$; não havia curso próximo ao local de trabalho $(1,1 \%)$; não teve interesse em fazer o curso $(15,6 \%)$; não conseguiu vaga $(0,7 \%)$; e outro motivo (22,0\%) (PNAD, 2009).

Diante do quadro acima destacado, entendemos que as citadas questôes reificam na memória coletiva a ideia de que, ao nos referirmos à EJA, 
enquanto modalidade educativa, quase que de forma automática venha à mente que nesse processo estaria um grupo de pessoas que não teve acesso à escola na idade socialmente "considerada ideal". Ou então, em sujeitos que, mesmo tendo tido a oportunidade de frequentar a escola, não conseguiram dar continuidade à experiência. Dito de outra forma, ao nos remetermos a esse grupo social, conclui-se que se trata de pessoas submetidas ao processo inicial da escolarização, com raras possibilidades de ultrapassar o ensino fundamental.

Acreditamos que Minayo (2007, p. 108) nos ajuda a esclarecer a questão acima apontada, ao afirmar que

as Representações Sociais se manifestam em palavras, sentimentos e condutas e se institucionalizam, portanto, podem e devem ser analisadas a partir da compreensão das estruturas e dos componentes sociais. Sua mediação privilegiada, porém, é a linguagem, tomada como forma de conhecimento e de interação social. Mesmo sabendo que ela traduz um pensamento fragmentário e se limita a certos aspectos da experiência existencial, frequentemente contraditória, possui graus diversos de claridade e nitidez em relação à realidade.

Concordando com a tese de que as representações são construídas no decurso do tempo e, nesse sentido, que a imagem dos sujeitos da EJA advém de um processo histórico, cogitamos ainda que o distanciamento do Estado, no que tange às suas responsabilidades (a esse respeito podemos citar a ausência de prédios escolares em quantidade adequada, a qualificação necessária dos/as profissionais que atuam nas escolas), pode ter contribuído fortemente para a construção/manutenção dessa imagem, já que é "necessário reconhecer que o mesmo direito assegurado por lei ainda vem sendo negado a tantos brasileiros e brasileiras, representando a negação do direito à cidadania" (FERNANDES, 2012, p. 37).

Haddad (2007) argumenta que tais situações, de alguma forma, têm sido responsáveis por não propiciar aos/às educandos/as um sentimento prospectivo da educação. De acordo com o autor, é preciso que se instaure um processo de atendimento que possa garantir a continuidade dos estudos.

A dificuldade histórica do/a educando/a da EJA em dar continuidade ao seu processo de escolarização, pelos mais variados motivos, como já sublinhamos anteriormente, tende a alimentar a ideia de que pessoas do referido grupo social teriam limitadas condiçôes de tornarem-se estudantes 
universitários/as. Em nosso entendimento, essa é uma questão que tem estado presente inclusive no discurso das escolas que ofertam a educação básica.

De fato, ainda não é muito comum termos a presença de egresso/a da Educaçáo de Jovens e Adultos no interior da universidade. Pudemos confirmar a suspeição em torno dessa questão quando indagamos a uma turma do curso de Letras, da Universidade do Estado da Bahia, Campus XVIII, sobre a possível presença de estudantes na instituição, com experiência na EJA, durante a educação básica. De imediato tivemos a seguinte resposta: "Acho difícil você encontrar esse tipo de aluno aqui. A UNEB não é lugar deles não, aqui só têm jovens” (Nota de Campo, julho/2014).

A forma como a aluna se referiu ao estudante da EJA denota que, em seu imaginário, que não é só individual, mas também coletivo, os/as estudantes da EJA seriam pessoas mais velhas que, por essa razão, tenderiam a ser facilmente identificáveis. Nesse caso, vale ressaltar, tal realidade não condiz mais com a que encontramos nas escolas. Há mais de duas décadas a presença de jovens na EJA tem sido ampliada anualmente, o que tem promovido outro fenômeno: a juvenilização da EJA (BRUNEL, 2004). De acordo com a referida autora, a presença dos jovens em número cada vez mais elevado modificou o cotidiano escolar e as relaçóes estabelecidas entre os sujeitos que ocupam o espaço da escola.

$\mathrm{O}$ fato de as escolas da EJA terem sofrido mudanças em diversos aspectos, de forma especial no público que a frequenta, não modificou, ainda, a imagem produzida historicamente acerca dessa modalidade da educaçáo básica e, por conseguinte, sobre as pessoas que a frequentam.

A ideia de que o público da EJA seja composto por estudantes caracteristicamente identificáveis, parece não ser uma visão apenas da estudante universitária aqui referenciada, mas também de uma das professoras da universidade, com a qual conversamos. Ao ser indagada sobre a possível existência de estudantes na universidade, com experiência em EJA, ela respondeu:

Aqui, pelo menos nessa turma, não tem esse tipo de aluno não. Seriam facilmente identificados. Eles falam pouco, como se tivessem vergonha da exposição, e têm dificuldades de escrever. Já ministrei muito curso de formação para professores "do EJA" e sei como sấo esses alunos (Nota de Campo, julho/2014).

A resposta da professora nos possibilitou, tomando o conceito de representação social como ponto de reflexão, fazer as seguintes conjecturas: 
seu suposto conhecimento sobre o perfil de estudante da EJA e, nesse caso, sua confiança em caracterizá-lo é, na realidade, a verbalização da representação historicamente construída em torno desse grupo social, a qual, no imaginário coletivo e também individual, construiu uma imagem que afirma possuir esse/a estudante um perfil de pessoas subservientes e inseguras. Por essas e por outras razóes, se mostrariam estudantes calados/as, pouco envolvidos/as com as atividades realizadas no contexto da sala aula e com consideráveis dificuldades de aprender. Essa forma de enxergar os sujeitos da EJA, seja pelos profissionais da educação e/ou, de modo geral, pela sociedade, tem sido, de alguma forma, apontada por alguns pesquisadores $/ \mathrm{as}^{8}$ que têm estudado a temática nos últimos anos. Entretanto, como a pesquisa que aqui apresentamos irá mostrar, não podemos reduzir apenas a essa imagem o público em questão.

Um fato interessante é que, embora esteja contaminada pela ideia de que a EJA continua sendo composta por um público característico, como o que majoritariamente encontrava-se presente nas salas de aula até meados dos anos de 90, a resposta da professora, curiosamente, entra em contradição com o que o campus universitário nos mostrou, tendo em vista o fato de termos identificado ali 11 estudantes egressos/as da referida modalidade, dos quais oito encontram-se matriculados/as em dois dos quatro cursos de licenciatura em que a docente trabalha.

Contudo, é compreensível a forma como a professora e também a estudante responderam a nossa indagação. Primeiro, porque a presença de egressos/as da EJA no ensino superior ainda não é algo amplamente comum de se constatar. Segundo, o perfil de quem está chegando ao ensino superior tem se mostrado distinto daquele que continua permeando nosso imaginário. Em geral, trata-se de pessoas jovens e/ou jovens-adultas que tiveram acesso à escola ainda na infância e que, por razóes diversas, se viram obrigadas a interromper suas trajetórias escolares durante o fundamental II e/ou no ensino médio.

Sobre a questáo acima apontada, vale destacar que dados censitários têm demonstrado que o público que nos últimos anos tem frequentado a etapa final do ensino fundamental e, também, o ensino médio não possui o mesmo perfil daquele presente no dos anos iniciais do ensino

8 Vale (2013); Friedrich et al (2010); entre outros/as. 
fundamental. Noutros termos, o Censo Escolar 2013 mostra que os alunos que frequentam os anos iniciais do ensino fundamental da EJA têm perfil etário superior aos que frequentam os anos finais e o ensino médio dessa modalidade. Tal fato, então, sugere que os anos iniciais náo estão produzindo demanda para os anos finais do ensino fundamental de EJA. Do mesmo modo, considerando as idades dos alunos nos anos finais do ensino fundamental e no ensino médio de EJA, há evidências de que essa modalidade está recebendo estudantes provenientes do ensino regular, por iniciativa do/a aluno/a ou da escola (INEP, 2014).

Os elementos históricos e teóricos corroboram as perspectivas apresentadas em torno dos sujeitos que compóem a EJA. Dito de outra forma, mesmo diante da constataçáo de que a entrada na universidade nos dias atuais tem sido alargada, pensar na possibilidade de uma pessoa com experiência em EJA acessar a um curso universitário em instituiçóes públicas é considerado mais improvável do que deveria ser.

A assertiva acima enunciada ganha força no momento em que nos deparamos com o fato de que, embora os/as egressos/as da EJA estivessem presentes na universidade, discursos negavam a ideia de se ter entre os/as estudantes universitários/as pessoas oriundas do referido segmento. No mesmo espaço em que uma moça disse, ao responder a mesma pergunta mencionada anteriormente, que "a UNEB não é lugar deles não, aqui só têm jovens", uma estudante do IV semestre, do curso de Letras Vernáculas, ao ouvir, levantou-se e disse com bastante entusiasmo: "Opa, eu estou aqui! Fui aluna, sim, da Educação de Jovens e Adultos e estou aqui como você" (Nota de Campo, julho de 2014). Em outra turma, onde estudam duas egressas, $V$ semestre do curso de História, ao terminarmos de expor a razão da nossa presença na sala, uma das estudantes se levantou e proferiu com muita segurança: "Eu fui aluna da EJA com muito orgulho, fiz os anos finais do ensino fundamental e o médio. Aqui também é meu lugar" (Nota de Campo, setembro de 2014).

Com todo o cuidado que o fenômeno exige, nos pareceu bastante evidente que há uma representação social construída no imaginário da sociedade e, consequentemente, na escola, bem como na universidade sobre os sujeitos que frequentam escolas de EJA. Afinal,

a representação que temos de algo não está relacionada à nossa maneira de pensar e, contrariamente, porque nossa maneira de pensar e o que pensamos depende de tais representaçóes, 
isto é, no fato de que nós temos dada representação. Eu quero dizer que elas são impostas sobre nós, transmitidas, e são o produto de uma sequência completa de elaboraçóes e mudanças que ocorrem no decurso do tempo e sáo o resultado de sucessivas geraçôes. Todos os sistemas de classificaçãa, todas as imagens e todas as descriçóes que circulam dentro de uma sociedade, mesmo as decisôes científicas, implicam um elo de prévios sistemas e imagens, uma estratificação na memória coletiva e uma reprodução na linguagem que, invariavelmente, reflete um conhecimento anterior e que quebra as amarras da informação presente (MOSCOVICI, 2003, p. 37).

Podemos ousar a dizer que a imagem que ficou dos sujeitos da EJA é a de um tempo distante do que vivemos nos dias atuais, semelhante àquela descrita por Arroyo (2008, p. 29): "[...] desde que a EJA é EJA, os jovens e adultos são os mesmos: pobres, desempregados, vivem da economia informal, negros, vivem nos limites da sobrevivência”. Todavia, embora tenhamos consciência de que a situação da grande maioria dos/as estudantes da EJA ainda se encontra permeada pelas adversidades, sabemos que as políticas implementadas nos últimos tempos trouxeram para o universo da escola uma realidade diferente daquela de 25 anos atrás. Como exemplo, podemos citar a nossa pesquisa sobre a inserção de egressos/as da EJA no ensino superior, em universidade pública.

Acreditamos que a inserção de pessoas com experiências em EJA no ensino superior construirá, no decurso do tempo, uma imagem diferente da que ainda temos hoje. É notório que o acesso à última parte da escolarização básica tem ocorrido. E ainda, com o fim dessa etapa, a procura da experiência educativa em outros níveis tem se ampliado, fator que tem propiciado, em alguns casos, o acesso ao ensino superior. Como afirma Gadotti (2013, p. 22), o direito do/a jovem, do/a adulto/a e/ou do/a idoso/a à educação não se esgota no acesso, permanência e conclusão da educação básica: esse direito "pressupôe as condiçôes para continuar os estudos em outros níveis".

Temos que identificar e destacar que, para além do problema do analfabetismo que envolve quase 15 milhóes de brasileiros/as, há também um contingente de pessoas que buscam o acesso ao ensino superior, e entre essas existe a presença de sujeitos que têm em seus currículos escolares a experiência na EJA. Desse modo, podem ser citados os trabalhos de Bernardim (2013), Da Cruz (2011) e Mileto (2009), os quais 
apontam que os/as estudantes da EJA não buscam a escolarização apenas para concluir a educação básica. Há, entre a busca pela conclusão da escolarizaçáo básica, interesse subjacente de "cursar o Ensino Superior" (DA CRUZ, 2011, p. 99).

\section{Consideraçóes finais}

O exercício nos possibilita afirmar que a condição de suspeição com a qual o sujeito que vive/viveu experiência na EJA convive, da parte da sociedade, possui relaçáo direta com a forma com que a modalidade de educação voltada a esse público foi tratada. A EJA, enquanto modalidade educativa, historicamente, esteve à margem do sistema de educação pública no Brasil, se comparada a outras da educação básica.

Nessa medida, a forma como a sociedade enxerga o público da EJA possui intrínseca relação com a forma com que a referida modalidade vem sendo tratada enquanto Política Pública: com descaso e abandono. Muitas escolas ainda continuam sendo espaços inapropriados para se desenvolver o ensino e a aprendizagem. Essas perversas condiçóes, certamente, ajudam a alicerçar e, sobretudo, a preservar a imagem, historicamente, construída sobre o sujeito da EJA.

\section{Referências}

ABRIC, Jean-Claude. A abordagem estrutural das representaçóes sociais. In: MOREIRA, Antônia Silva Paredes; OLIVEIRA, Denize Cristina de. (Org.). Estudos interdisciplinares de representaçáo social. Goiânia: AB, 2000.

ALVES-MAZZOTTI, Alda Judith. Representações sociais: aspectos teóricos e aplicaçōes à Educação. Em Aberto, Brasília, ano 14, n. 61, p. 60-78, jan./mar., 1994.

ARROYO, Miguel González. A educação de Jovens e Adultos em tempos de exclusão. In: AUTOR. Construção coletiva: Contribuiçôes à Educação de Jovens e Adultos. Brasília: UNESCO; MEC; RAAAB, 2008.

BERNARDIM, Márcio Luiz. Educação e trabalho na perspectiva de egressos do Ensino Médio e estudantes universitários. Nuances: estudos sobre Educação, Presidente Prudente, SP, v. 24, n. 1, p. 200-217, jan./abr., 2013. 
BRUNEL, Carmem. Jovens cada vez mais jovens na educaçáo de jovens e adultos. Porto Alegre: Mediação, 2004.

DA CRUZ, Neilton Castro. Casos pouco prováveis: trajetórias ininterruptas de estudantes da EJA no ensino fundamental. 2011.118 f. Dissertação (Mestrado em Educação) - Faculdade de Educação, Universidade Federal de Minas Gerais, Belo Horizonte/MG, 2011.

DI PIERRO, M. C. Notas sobre a redefinição da identidade e das políticas de EJA no Brasil. Educação e Sociedade, Campinas, vol. 26, n. 92, p. 1115-1139, out., 2005. (Especial)

FAAR, Robert M.Representaçóes Sociais: a teoria e sua história. In: GUARESCHI, Pedrinho; JOVCHELOVITCH, Sandra (Org.). Textos em representaçôes Sociais. 9. Ed. Petrópolis: Vozes, 2007, p. 17-25.

FÁVERO, Osmar. Liçôes da história: os avanços de 60 anos e a relação com as políticas de negação de direitos que alimentam as condiçôes do analfabetismo no Brasil. In: PAIVA, Jane \& OLIVEIRA, Inês B. de. (Orgs.). Educaçáo de Jovens e Adultos. Petrópolis, RJ: DP et Alii, 2009.

FERNANDES, Andrea da Paixão. Memórias e representaçóes sociais de jovens e adultos: lembranças ressignificadas da escola da infância e expectativas no retorno à escola. 2012. 374 f. Tese (Doutorado em Educação) - Faculdade de Educação, Universidade Estadual de Campinas, Campinas, SP, 2012.

GALVÃO, Ana Maria de Oliveira; DI PIERRO, Maria Clara. Preconceito contra o analfabeto. 2. ed. São Paulo: Cortez Editora, 2013.

GADOTTI, Moacir. Educação de Adultos como Direito Humano. EJA EM DEBATE, Florianópolis, n. 2. p. 12-29, jul. 2013.

GUARESCHI, Pedrinho; JOVCHELOVITCH, Sandra. Introdução. In: GUARESCHI, Pedrinho; JOVCHELOVITCH, Sandra (Org.) Textos em Representaçóes Sociais. 9. ed. Petrópolis: Vozes, 2007.

HADDAD, Sérgio. Por uma nova cultura na Educaçáo de Jovens e Adultos: um balanço de experiências de poder local. Editora Global e Ação Educativa. Outubro de 2007.

Instituto Nacional de Estudos e Pesquisas Educacionais Anísio Teixeira - INEP: Censo Escolar da Educação Básica 2013: resumo. Brasília: INEP, 2014.

Instituto Brasileiro de Geografia e Estatística - IBGE. Pesquisa nacional por amostra de domicílios: aspectos complementares da Educação de Jovens e Adultos 
e Educação Profissional Pnad 2007. (PNAD, 2009)Disponível em: <http://www. ibge.gov.br/home/>. Acesso em: 10 jun. 2010.

IRELAND, Timothy. Objetivos maiores que a alfabetização: EJA - Educação de Jovens e Adultos. Revista Nova Escola, São Paulo, jun./jul. 2009. Disponível em: <http://acervo.novaescola.org.br/politicas-publicas/modalidades/eja-tem-agoraobjetivos-maiores-alfabetizacao-476424.shtml>. Acesso em: 05 out. 2014.

MILETO, Luís Fernando Monteiro. "No mesmo barco, um ajuda o outro a não desistir" - Estratégias e trajetórias de permanência na Educação de Jovens e Adultos. 2009. 216 f. Dissertação (Mestrado em Educação) - Faculdade de Educação, Universidade Federal Fluminense, Niterói, 2009.

MINAYO, Maria Cecília de Souza. O conceito de Representações Sociais dentro da Sociologia Clássica. In: GUARESCHI, Pedrinho \& JOVCHELOVITCH, Sandra (Orgs). Textos em Representaçóes Sociais. 9. ed. Petrópolis, RJ: Vozes, 2007.

MOSCOVICI, Serge. Representaçóes sociais: investigação em psicologia social. Tradução Pedrinho A. Guareschi. Petrópolis-RJ: Vozes, 2003.

NOGUEIRA, Maria Alice; NOGUEIRA, Cláudio M. Martins. Bourdieu e a Educação. Belo Horizonte: Autêntica, 2004.

SILVA, Valdélio Santos. Políticas de açóes afirmativas na UNEB: Memórias de um acontecimento histórico. Mujümbo, v. 1, n. 1, jul., 2010.

WAGNER, Wolfgang. Sócio-gênese e características das representaçôes sociais. In: MOREIRA, Antonia Silva Paredes; OLIVEIRA, Denize Cristina de. (Org.). Estudos interdisciplinares de representação social. Goiânia-GO: AB, 2000. 


\title{
A LUTA SOCIAL ENSINA: O DIREITO À EDUCAÇÃO NA VIDA DE MULHERES E HOMENS SISALEIROS
}

\author{
Edite Maria da Silva de Faria ${ }^{1}$
}

Os sonhos são os projetos pelos quais a gente luta.

(FREIRE, 2001)

\section{Introduçáo}

A escrita, muitas vezes, é uma peleja realizada numa solidão quase absoluta. A minha escrita brota do trabalho solidário e coletivo, do encontro de pessoas, ideias, saberes, fazeres e sonhos. Povoada de vozes, trajetórias, desejos, entusiasmos, expectativas e possibilidades. Histórias de homens e mulheres e de imagens cotidianas da vida. Histórias impregnadas de privaçôes, lutas, agruras, persistências e de resistência.

Parto do princípio de que homens e mulheres são sujeitos historicamente datados e socialmente situados, autores de sua própria existência e essa autoria é o fundamento básico do processo social. $\mathrm{O}$ ato de narrar sua própria história, mais do que contar história sobre si e compartilhar experiências, é um ato de conhecimento. Revela modos de pensamento e reflete formas de organizar, criar e recriar, cotidianamente, o mundo.

Mulheres e homens sertanejos sisaleiros que estão vinculados diretamente às lutas sociais e que são marcados direta ou indiretamente pelo motor do sisal, pais e máes de família, na faixa etária de 27 a 52 anos, herdeiros de um legado de negação de direitos básicos, mas também de muita luta, resistência e esperança.

1 Doutora em Educação e Contemporaneidade pela Universidade do Estado da Bahia (UNEB). Professora adjunta do Departamento de Educação - Campus XIV e Professora Permanente do Mestrado Profissional de Educação de Jovens e Adultos (MPEJA) da UNEB, pesquisadora do Grupo de Estudos e Pesquisas em Política e Avaliação Educacional (GEPALE) da Faculdade de Educação da Universidade Estadual de Campinas (FE/UNICAMP) e do Grupo de Pes- quisa Educação do Campo e Contemporaneidade do Programa de Pós-Graduação em Edu- cação e Contemporaneidade (PPGEduC) da UNEB. Membro da Coordenaçáo Colegiada do Fórum Regional de EJA do Território do Sisal da Bahia.E-mail: <editedefaria@gmail.com>. 
Como se produz o direito à educação na vida de mulheres e homens de Nova Palmares, no município de Conceição do Coité, pertencente ao Território do Sisal da Bahia, e como vivem o cotidiano e os processos de aprendizagem no assentamento? Quem são, o que pensam, fazem, desejam e demandam estes sujeitos? A escola e os outros espaços de aprendizagem têm respondido de que maneira às suas demandas? Qual a importância da educação na vida deles? E que educação está disponibilizada para eles?

A educação de jovens, adultos e idosos, numa perspectiva transformadora e forjada no movimento concreto da luta dos trabalhadores, pode fazer sua parte, esboçando conexóes entre as várias lutas com as quais os diversos movimentos e sujeitos (seus processos são feitos por eles e com eles e não para eles) estão engajados, na direção da superação e transformação da sociedade que se organiza, tendo por base as desigualdades sociais e o não direito.

Marcados direta ou indiretamente pelo motor do sisal no corpo e na existência, as mulheres e os homens deste estudo mostram sua importância e singularidades em busca de igualdade e conquistas através das trajetórias de idas e voltas, avanços e recuos, de caídas e recaídas. Geralmente, de escolhas sem horizontes definidos, mas também de luta, resistência e muita fibra.

\section{Ser Sisaleiro: herdeiros de um legado de privaçóes e resistências}

E o sertão é um vale fértil. É um pomar vastíssimo, sem dono [...]

(Euclides da Cunha, 1901)

A Bahia tem um cenário de paisagens heterogêneas. Seu vasto território abriga muitos tipos de ecossistemas. No semiárido, na região do Sertão, a vegetação predominante é a caatinga. Em Os sertôes, grande clássico da literatura nacional de Euclides da Cunha, esse cenário sertanejo está descrito extraordinariamente.

Apesar das dificuldades e pelejas, os sertanejos mantêm uma relação singular com o lugar onde vivem. O Sertão é marcado pela força, pelo espírito de luta e de resistência de mulheres e homens, estes na saga da vida continuamente labutam historicamente contra a seca e a exploração.

O Território do Sisal possui no meio do Sertão semiárido uma singularidade que rompe com as tentativas de uniformizaçáo. Nas suas paisagens 
desabrocham sisal, mandacarus, caroás, facheiros, macambiras e gravatás. Além disso, são pontilhadas por lajedos, carrascais e tabuleiros. O sertanejo desta regiấo vive do trabalho e também da alegria através das expressóes culturais locais, tais como: vaquejadas, festas (juninas, padroeiros e colheita) e reisados.

Muitas vezes, sem o incentivo e financiamento de políticas públicas que valorizem efetivamente as manifestaçôes artísticas de caráter popular, muitos artistas anônimos fortalecem a cultura sisaleira compondo, cantando, escrevendo, pintando, dançando, esculpindo, encenando, trançando artesanato com as fibras do sisal.

Eles contribuem significativamente para o sentimento de pertencimento e o fortalecimento da identidade cultural do povo do Território do Sisal. Outros elementos váo se reunindo no espaço e no tempo para a constituição da cultura do povo sisaleiro, conferindo-lhe características singulares dentro da diversidade baiana.

A história e os costumes da população contribuem para a identidade de "ser sisaleiro", pois ressaltam: são "mulheres e homens de fibra", herdeiros de um legado de privaçóes, mas também de lutas e resistências, concebidas como a capacidade de colocar-se frente às dificuldades e desafios do cotidiano com uma atitude de esperança, crença e perseverança. O contrário da resistência seria a entrega a um destino imutável e dado previamente.

Outra característica da resistência é a criatividade para desenvolver táticas e estratégias, indo desde a sobrevivência até complexas formas de organização e de lutas no campo político, social, econômico, religioso e cultural. Tática, aqui concebida a partir do conceito que Michel de Certeau utiliza para designar a "ação calculada que é determinada pela ausência de um próprio; tática é movimento, dentro do campo de visão do inimigo e no espaço por ele controlado, que opera golpe por golpe, lance por lance, aproveitando as ocasióes" (CERTEAU, 1996, p. 100-101). Em suma, a tática é a arte do fraco.

As táticas apresentam continuidades e permanências, sem cessar, o fraco tira partido de forças que lhe são estranhas para poder sobreviver diante das lutas e desigualdades ocultas, muitas vezes, sob a ordem estabelecida. Ser mulher e homem sisaleiros torna-os sujeitos históricos os quais com seus saberes, fazeres e com solidariedade contribuem para o desenvolvimento do Território do Sisal que não é diferente de outras regiôes do Nordeste brasileiro: herdou a cultura do latifúndio, do assistencialismo, 
do paternalismo, e uma forte visão místico-religiosa de mundo, reforçada pelo coronelismo que construiu a base política para sua consolidação.

No contexto do Território do Sisal, a organização dos movimentos sociais e a articulação de açôes visando à implantação de um processo de desenvolvimento sustentável são legados de muitas lutas e resistências, inclusive contra as desigualdades do acesso à terra.

$\mathrm{O}$ uso da terra é a expressão das diferentes atividades econômicas que ocorrem no Território do Sisal. A agricultura familiar é a base da sua economia. O desenvolvimento do rebanho caprino e ovino, o extrativismo pela produçáo de carvão, pelo aproveitamento das rochas e outras atividades similares contribuem significativamente para a sobrevivência dos sisaleiros. A possibilidade de consórcio e de diversificação da produção da agricultura familiar do Território do Sisal e as atividades voltadas para a subsistência garantem renda e segurança alimentar para os agricultores familiares e para a população em geral.

A cadeia produtiva do sisal sofre com vários fatores para além da prolongada seca que se abate sobre a regiáo, especialmente, as arcaicas relaçóes trabalhistas predominantes no setor ainda incompatíveis com a legislação vigente e potencializam as desigualdades sociais.

Uma nova conjuntura, política e institucionalmente descentralizada aliada à participação social delineiam os novos rumos frente às realidades geográficas que se intercruzam a fim de estabelecer uma nova dinâmica socioespacial para o Território do Sisal, em que a autonomia de participação torna-se o elo central para a consolidação de um novo cenário democrático a caminho da cidadania.

\section{Identidade dos sujeitos sisaleiros: mulheres e homens de fibra}

Desde 2003, quando assumi o cargo de professora universitária no Departamento de Educação - Campus XIV, de Conceição do Coité, meu foco sempre foi trabalhar com mulheres e homens sisaleiros. Conhecer suas histórias, trajetórias de vida que, desde crianças, as interrogam e interrogam a educação sobre os significados políticos da miséria, da fome, da luta pela terra, pela identidade e pela sua cultura, pela vida e dignidade aumentou meu desejo e comprometimento como pesquisadora.

O extraordinário espírito de luta e esperança dos seguidores de Zumbi dos Palmares e de Antônio Conselheiro que sobreviviam em condiçóes 
precárias, as mais adversas, seja devido à pobreza e sobretudo devido às truculências do coronelismo e ao descaso do governo, desvela e coloca em evidência o sofrimento e desencanto que, infelizmente, chega aos dias atuais, pois a miséria, a injustiça, as desigualdades continuam a condenar mulheres e homens brasileiros, especificamente os sertanejos sisaleiros, apesar de muitas lutas e resistências.

Percebo que a luta por terra não é algo para ser analisado isoladamente, questôes referentes à educação, trabalho, segurança, moradia, saúde estão interligadas e precisam de análise mais profunda. As idas e vindas aos diferentes espaços de sociabilidades contribuíram para aprofundar e ampliar o olhar, pois a partir da convivência e da aproximação com os sujeitos sisaleiros surgiram o desejo e a necessidade de identificar quais estratégias e táticas eram utilizadas no cotidiano para lutar contra a opressão e a submissão; como se organizavam e, especialmente, qual concepção de educação se materializava, especialmente no Assentamento Nova Palmares, no município de Conceição do Coité.

Mulheres e homens que possuem percursos de idas e voltas, avanços e recuos, de caídas e recaídas; geralmente, de escolhas sem horizontes definidos, mas também de luta, resistência e persistência. Suas memórias e cotidiano ensinam saberes, fazeres e modo de ser e estar no mundo, de maneira singular.

Nova Palmares é uma homenagem ao Quilombo dos Palmares², cenário de uma das mais significativas histórias de resistência à escravidão ocorrida no mundo. Segundo relatos dos moradores e a partir da análise de documentos ${ }^{3}, 189$ famílias que não possuíam terras e que lutavam pela sobrevivência, vindas de cinco municípios da Região Sisaleira da Bahia (Conceição do Coité, Ichu, Retirolândia, São Domingos, Santa Luz e Valente), depositaram na reforma agrária a esperança de abrir caminhos para a conquista da terra. Configurou-se um processo de luta e resistência que

2 O maior, mais duradouro e mais organizado refúgio de escravos das Américas. Nele, reinou Zumbi dos Palmares, o herói negro assassinado em 20 de novembro de 1695, data em que se comemora o Dia Nacional da Consciência Negra.

3 Além do Plano de Desenvolvimento Sustentável do Projeto de Assentamento Nova Palmares também foram consultados o relatório de Vistoria e Parecer Técnico (1999), o Estatuto da Associação dos Pequenos Produtores Assentados do Projeto Nova Palmares (APPAPNP) e o Regimento Interno do Assentamento. 
aconteceu por meio da ocupação da Fazenda Berimbau, propriedade de Theócrito Calixto da Cunha, ex-prefeito da cidade.

A ocupaçáo foi planejada por dois anos e na madrugada do dia 12 de janeiro de 1998, as famílias já reunidas no povoado de Lagoa Grande, local próximo à fazenda, ocuparam a propriedade. A maioria dos líderes era filiada ao Sindicato dos Trabalhadores Rurais (STR), do município de Retirolândia e o apoio dado aos assentados foi fundamental nesse processo.

Reuniōes foram realizadas e a ocupação ocorreu sem conflito, contudo os acampados adotaram apelidos para náo serem identificados com os seus verdadeiros nomes, uma estratégia usada para se proteger de possíveis represálias e perseguiçóes. Havia sempre um grupo de acampados na entrada da ocupação, fazendo a vigilância e a segurança dos demais.

As dificuldades inicialmente enfrentadas foram superadas com açóes e atitudes de solidariedade e coletividade. O período da ocupação foi marcado pela escassez de chuva e muita seca. Assim, os trabalhadores que cortavam sisal náo tinham nenhuma atividade na cadeia produtiva.

A produçáo econômica do assentamento está baseada no cultivo de sisal, e tem a criação de caprinos como principal atividade, além do cultivo de milho, feijão, mandioca, hortaliças e criação de galinhas. Neste contexto materializa-se o sistema de produção do sisal que, através da organização e uso de estratégias, assegura sobrevivência dos assentados dentro de Nova Palmares.

Toda a produçáo destina-se à subsistência da família, a maior parte é para o autoconsumo, uma menor é enviada ao mercado, e com os recursos recebidos na venda dos produtos, adquirem outros bens. Há uma iniciativa no assentamento de comercializaçáo coletiva de uma parcela da produção. Existe ainda no assentamento o projeto de instalação de uma batedeira comunitária.

Os moradores de Nova Palmares buscam, pela união, resistir às dificuldades. O meio ambiente, visto como o espaço onde ocorrem as relaçóes e as práticas sociais da população, não fica, assim, restrito às questóes de ordem física, mas configura-se como o resultado e produto das açóes de mulheres e homens mediadas pelo trabalho, construindo os espaços do viver. Um dos princípios fundantes do assentamento é a organização materializada através dos grupos de jovens, mulheres, produçáo e incentivo à cultura.

Nova Palmares é um assentamento diferenciado não somente por evitar a migraçáo de jovens e adultos, mas por mostrar a capacidade 
política do povo sertanejo sisaleiro, e especialmente das mulheres e homens sisaleiros. A realidade do assentamento não é diferente de tantos outros assentamentos em nosso país. Um desafio diário é conseguir manter os jovens no campo com expectativa de qualidade de vida. Os assentados buscam com seus próprios esforços construir suas trajetórias que valorizem a vida e a cultura local.

A capacidade de organização e da produção coletiva faz a diferença entre outros assentamentos do Território do Sisal. A produçáo coletiva descortina possibilidades de superar e romper com o modelo antigo, legado do coronelismo e da opressão. Nova Palmares torna-se um referencial de possibilidades do trabalho coletivo que pode mudar a correlaçáo de forças no campo, pela organização, pela competência e solidariedade.

O cotidiano de Nova Palmares é um lugar de possibilidades, onde os problemas concretos dos assentados ganham sentido. É ali que se exerce a atividade criadora, onde sujeitos coletivos se constroem, e (re)constroem, pela ação, o lugar onde vivem. O cotidiano vivo e vivido de Nova Palmares é um espaço de possibilidades.

Alguns assentados se consideram mais engajados do que outros no processo de organização e gestão do assentamento, comprometendo-se, assumindo a coordenação dos trabalhos e de comissóes, e também da direção e outras atividades no assentamento. Demonstram ter maior compreensão do que é assentamento e o que representa para eles. Portanto, assumem tudo sozinhos, sendo vistos pelos outros como únicos responsáveis.

Compreender o que motivava estas pessoas a continuar na luta social, reivindicando, conquistando, ou seja, participando deste processo com disponibilidade e compromisso, mesmo com outros assentados desmobilizados e acomodados depois do acesso à terra e que ainda não conseguem conceber o assentamento como um espaço coletivo e de luta permanente, suscitou questóes relevantes: Por que uns não participam? O que impede e o que dificulta esta participaçáo? O que move uns a participar e outros não? Como estão participando?

A vontade de participar contribui significativamente para manter o espírito de luta que acompanha a maioria dos assentados de Nova Palmares, em seu cotidiano consolidam os avanços e conquistas cujas marcas já são significativas dentro do assentamento.

Em Nova Palmares, existe a preocupação de formar lideranças. Os assentados investem na formação educacional, política e social dos jovens. Uma preocupaçáo constante é incluir a juventude nas diferentes 
atividades educacionais, culturais, políticas e sociais locais. Um desafio constante é criar alternativas para os jovens permanecerem no Assentamento, visto que alguns deles foram embora para a sede do município, outros para Salvador, Minas Gerais, São Paulo e Mato Grosso. A educação torna-se essencial neste processo, especialmente quando está alicerçada na concepção popular transformadora.

Nesta perspectiva, o subjetivo adquire o seu lugar: o seu aqui e agora, contrariando e contestando as abordagens totalizadoras que engessam e reduzem a vida social em categorias abstratas, ignorando seus fazeres, saberes, desejos, medos, sonhos, enfim, a complexidade da experiência humana.

A garantia de oportunidades educacionais aos que não ingressaram na escola ou dela foram excluídos precocemente significa muito mais que lhes dar a oportunidade de ocupar outro espaço no mercado de trabalho. A questão econômica, os problemas no âmbito familiar e a exclusão no âmbito escolar marcaram extraordinariamente as trajetórias de vida e escolar das mulheres e homens do assentamento.

A visão economicista e a tecnicista de gestores, muitas vezes, provocam o cerramento das portas das escolas do campo, contrariando a luta daqueles que materializam a educação popular do campo. Isto porque o fechamento de cada escola contribui para a negação do direito à formação humana no campo, não apenas dos adultos e idosos, mas também da infância e da juventude.

Assim, o campo sofre por não vivenciar uma educação específica, para atender a suas reais necessidades e demandas, de modo que sua população possa experienciar de fato a cidadania participativa.

Nos municípios do Território do Sisal, a realidade não difere dos demais municípios baianos no que diz respeito aos desafios de atender às demandas da população, com maior gravidade para as mulheres e os homens do campo, especialmente pelo caráter descontextualizado, homogeneizante, fragmentado e descontínuo do processo de ensino, aprendizagem e, principalmente, das políticas educacionais para os sisaleiros.

A inegável precarização histórica da educação oferecida aos sujeitos sisaleiros, especificamente aos jovens, adultos e idosos, muitas vezes deslocada da sua realidade, baseia-se numa matriz urbanocêntrica de sociedade, homem e mundo. Daí surge a necessidade de uma intensa mobilização dos movimentos sociais populares do campo para afirmar o direito à educaçáo e à vida com dignidade para os camponeses, especialmente no planejamento, implementação e avaliação destas políticas. 
Historicamente, muitas crianças e jovens sisaleiros não tiveram a oportunidade de acesso à educação escolar e hoje são adultos e idosos herdeiros de um legado de privaçóes e desigualdades. Entretanto, demonstram através das trajetórias de vida, da organização, militância e mobilização as estratégias de luta e resistência.

As mulheres e os homens sofreram com a homogeneização da política educacional e fundiária que não os considerava como sujeitos, nem contribuíam com suas necessidades, tampouco para o desenvolvimento local. Muitos sisaleiros tiveram seus direitos à terra, ao trabalho, à segurança, à saúde e à educação negados.

Diferentes movimentos sociais atuam efetivamente na busca de garantia dos direitos da população sisaleira. Eles se configuram como espaços fundamentais de participação e intervenção social. A história dos municípios do Território do Sisal é marcada por forte participação de movimentos sociais, populares, sindicais e organizaçóes sociais, como as Comunidades Eclesiais de Base (CEB), a Associação de Desenvolvimento Solidário e Sustentável da Região Sisaleira (APAEB), o Sindicato dos Trabalhadores Rurais (STR), a Fundação de Apoio aos/as Trabalhadores/ as Rurais, Agricultores/as Familiares da Região do Sisal e Semiárido da Bahia (FATRES), o Movimento de Organização Comunitária (MOC) e tantos outros que fazem parte do legado de lutas, resistências e conquistas dos sisaleiros.

Rememorar a história das lutas e conquistas dos movimentos sociais populares do campo ao longo da história brasileira e especificamente sisaleira é um desafio. Trata-se de um percurso que nem sempre possui registros os quais, muitas vezes, quando existem, estão dispersos e fragmentados. Esta, também, uma característica da própria trajetória da maioria dos camponeses que ao longo da história foram explorados, subordinados politicamente, privados de direitos políticos, sociais, educacionais, culturais e econômicos.

Muitas vezes, a memória social destes sujeitos históricos foi intencionalmente obscurecida, fragmentada e especialmente invisibilizada. Geralmente, a imagem que herdamos e aprendemos dessas mulheres e homens do campo está vinculada à versão historicamente construída pelos "vencedores do processo histórico".

Desde o Período Colonial, os sujeitos do campo permanecem na condição de subalternidade, mantidos vivos sob a condição de morte civil, segundo Boaventura Sousa Santos (1999). Mulheres e homens 
vivem num processo perverso de privação de direitos, sendo considerados, segundo Bauman (2007), refugos humanos. Antônio Dias Nascimento (2009, p. 196) afirma:

Talvez, pelo fato de que os registros mais destacados da história do Brasil tenham sido escritos até hoje, a partir do alpendre da casa grande ou das sacadas dos sobrados, a história da opressão não tenha sido tão realçada, nos sistemas escolares voltados para os setores populares, assim como seus efeitos sobre as subjetividades dos oprimidos.

Mesmo a história sendo construída pelos "vencedores", os mecanismos políticos, sociais e econômicos que negaram direitos aos camponeses deram origem, também, a testemunhos sobre resistência, revolta, organização e luta em busca de igualdade e conquistas.

Tendo como referência a caminhada histórica da Educação Popular (EP) no Brasil, perpassando também pela América Latina, percebemos que para superar as lacunas do poder público em relação à negação de direitos básicos, os movimentos sociais populares envolvidos com as populaçóes da cidade e especialmente do campo têm forjado processos emancipatórios em diferentes espaços de luta e aprendizagem para os camponeses.

A diversidade sempre foi uma característica do movimento de EP no Brasil. No Território do Sisal, especificamente no campo da educação, surgem novos conceitos e novas formas de se organizar e agir, assim como novos movimentos sociais, neste novo modo de ser e se fazer movimento social. A luta social ensina, não apenas a escola.

Este cotidiano onde se desenrolam suas lutas recria o espaço tão carente de infraestrutura, apropriando-se dele pelas redes de solidariedade e novas vinculaçóes estabelecidas com outras pessoas e com a história da localidade, e onde tecem outros saberes, buscando organizar um movimento para a conquista de direitos negados, tais como: o direito à terra, à educaçáo, à saúde, à segurança, ao saneamento básico, enfim, a uma melhor qualidade de vida.

O território cotidiano destes sujeitos é um espaço no qual venho trilhando os itinerários e percursos de minha trajetória profissional e humana. $\mathrm{O}$ cotidiano me desafia no que se refere à prática da pesquisa, pois mais que buscar novos enfoques metodológicos necessários e requeridos para explicar a relação educação $\mathrm{x}$ sociedade na contemporaneidade, subsidia-me a tecer 
novas configuraçóes teórico-metodológicas que apontem para outras possibilidades interpretativas do(s) saber(es), fazer(es) e memória(s) das mulheres e homens sisaleiros.

O cotidiano é aquilo que nos é dado cada dia (ou que nos cabe em partilha), nos pressiona dia após dia, nos oprime, pois existe uma opressão do presente. Todo dia, pela manhá, aquilo que assumimos, ao despertar, é o peso da vida, a dificuldade de viver, ou de viver nesta ou noutra condiçãa, com esta fadiga, com este desejo. O cotidiano é aquilo que nos prende intimamente, a partir do interior. É uma história a meio-caminho de nós mesmos, quase em retirada, às vezes velada. Não se deve esquecer este "mundo memória", segundo a expressão de Péguy. É um mundo que amamos profundamente, memória olfativa, memória dos lugares da infância, memória do corpo, dos gestos da infância, dos prazeres [...] (CERTEAU; GIARD; MAYOL, 1996, p. 37).

O cotidiano é o espaço onde as pessoas vivenciam as mudanças que acontecem no mundo, recriando na vida diária as estratégias de resistências e/ou adaptação a essas mudanças. Também é espaço onde a expressividade oral, corporal, as tramas políticas, as representaçôes religiosas, as estratégias de sobrevivência física e cultural aparecem driblando, muitas vezes, o silêncio imposto pelas diferentes formas de exclusão.

O cotidiano de mulheres e homens desvela e desvenda as trajetórias de vida em que sempre pelejaram em prol da coletividade e da justiça, mesmo sendo herdeiros de um legado de privaçóes e discriminaçôes.

\section{Desafios da Educaçáo de Jovens e Adultos do Campo: laços e embaraços}

Pensar a educação na relação com a sociedade e o desenvolvimento sustentável é pensar a partir da ideia de que o local, o território, pode ser reinventado através das suas potencialidades. Uma das formas de trazer à tona essas potencialidades está na revitalização da importância do coletivo como estratégia de participação popular de gestão das políticas. Assim, cada proposta de desenvolvimento possui sua visão de homem, de sociedade, de mundo desejado. 
As políticas públicas, particularmente as direcionadas para o campo da educação de jovens, adultos e idosos ainda náo contemplam de fato e verdadeiramente o sujeito do campo como protagonista do processo de desenvolvimento, como condição para a participação na construçáo de sociedades mais justas, solidárias, pacíficas, sustentáveis e que a diversidade de fato se constitua a riqueza que nos identifica como brasileiros.

O campo brasileiro é composto de diversas e singulares realidades sociais, econômicas, culturais e geográficas. Assim, os projetos e propostas educativas asseguram uma concepção/conotaçáo variável e possuem intencionalidades específicas que, muitas vezes, não dialogam e tampouco atendem as demandas dos camponeses.

Neste contexto, não atendem de forma significativa e abrangente às reais necessidades e desejos dos trabalhadores do campo, não privilegiam as múltiplas realidades vividas por esses sujeitos, seus saberes socialmente e historicamente construídos e impõem uma concepção/conotação estigmatizada sobre sujeitos do campo.

Por outro lado, a concepção de educação centrada no processo de humanização e conscientização contribui com os sujeitos do campo na medida em que fortalece a luta para viver e produzir no campo. Desvela a realidade perversa, subsidia os sujeitos para resistirem e continuarem na peleja contra a negação de direitos.

Um dos desafios contemporâneos da educação para jovens, adultos e idosos do campo é enfatizar os processos de formação humana, tendo como ponto de partida os parâmetros de um ser humano concreto e historicamente situado e contribuir para que se perceba, se organize e se reconheça como sujeito coletivo e cidadão de direito. Em síntese, como mulheres e homens de possibilidades.

A busca contínua pelo protagonismo dos movimentos sociais e populares vem conquistando um conjunto de açôes no âmbito das políticas públicas para atender os sujeitos do campo, especialmente no contexto sisaleiro. Entretanto, a ausência do poder público, mitigada, faz com que a responsabilidade e a culpa por essa indiferença recaiam sobre os próprios camponeses.

Tenta-se esconder a hegemonia das classes dominantes sobre o Estado, atribuindo-se às desigualdades sociais um caráter de inferioridade natural e não de característica endógena ao desenvolvimento do capitalismo no Brasil, no contexto baiano e sisaleiro. Isto é evidenciado pelo fato de serem as políticas educacionais filantrópicas e assistencialistas, além de descontínuas, pulverizadas e populistas. 
A educação de jovens, adultos e idosos, concebida a partir dos anseios e demandas dos seus sujeitos, pode ser vista e reconhecida como uma política pública de direito social, configurando-se e contrapondo-se à educação que está a serviço do mercado.

Ao se pautar em uma concepção de campo e de desenvolvimento que não exclui as lutas, as resistências sociais, reconhece as possibilidades de criação de novos territórios de vida e que não comunga com a educação excludente e perversa pautada pelo mercado, no desenvolvimento capitalista fomentando a realidade desumana das precárias condiçóes do campo, consubstancia outro tipo de política pública de direito social.

A educação como processo contínuo e constante de conscientização e humanização reconhece os camponeses não apenas por suas carências, mas por serem participantes de um processo de luta e transformação das relaçóes sociais com o campo. Deste modo, caminha de forma a romper com a estigmatização, com o preconceito e a discriminação historicamente construídos. Supera, assim, a visão preconceituosa de sujeitos da falta e os reconhece como sujeitos de direitos e possibilidades.

O que se observa são os excluídos da escola também sendo excluídos de outros direitos essenciais. Seus saberes são sempre desconsiderados e desvalorizados. Logo, a diferença é tratada como ignorância e atraso, portanto, não é considerada legítima. E, além de excluídos do âmbito escolar, são também privados das decisóes e da participação político-social. Apesar de se sentirem "excluídos no interior" da própria sala de aula, não abandonam a escola, como fizeram outros colegas. Segundo Bourdieu e Champagne (1998b, p. 224):

Obrigados pelas sanções negativas da Escola a renunciar às aspiraçóes escolares e sociais que a própria Escola lhes havia inspirado, e, em suma, forçados a diminuir suas pretensóes levam adiante, sem convicção, uma escolaridade que sabem não ter futuro.

A trajetória escolar regular e convencional sem atrasos, reprovaçóes sucessivas e interrupçóes nos estudos constitui-se, na maioria das vezes, em uma realidade apenas para os sujeitos oriundos dos meios sociais favorecidos, portanto, para os sujeitos dos setores populares e, especialmente do campo, não é possível. Para eles, essa trajetória é marcada por desafios, lutas e limitaçóes. 
Neste contexto, é imperioso identificar de que maneira e com que intensidade as condiçóes de existência afetam, por um lado, o destino escolar nas suas várias dimensões, entre elas, a duração da escolaridade, tipo de ensino, os resultados escolares obtidos, enfim a própria vivência da experiência escolar; por outro, as estratégias que cada sujeito utiliza para acessar e permanecer no processo de escolarização.

A educação de jovens, adultos e idosos no contexto brasileiro, baiano e sisaleiro ainda não conseguiu alicerçar-se em políticas de Estado, vive-se entre laços e embaraços, em síntese existe um fosso entre o dito e o feito. Historicamente, sua estrutura e funcionamento foram marcados e legitimados por políticas de governo, quase sempre sem avaliação dos seus impactos no contexto onde foram implantadas, sem tomar como ponto de partida a identidade dos sujeitos.

\section{Consideraçóes finais}

A educação no meio rural foi sempre tratada pelo poder público com políticas compensatórias. Historicamente não houve, no sistema de educação rural, a formulação de diretrizes (políticas/pedagógicas) para atender seu funcionamento, tampouco um financiamento que possibilitasse a institucionalização e manutenção de uma educação em todos os níveis, com qualidade e dignidade.

A educação, por si só, não promove a transformação social, mas sem ela esta transformação não é possível, como ensinou Freire. Não há como pensar o desenvolvimento do campo sem a educação dos camponeses. Os sujeitos do campo têm vida, saberes, fazeres, formas de ser e estar no mundo. A educação é condição sine qua non para uma política econômica justa e ecologicamente sustentável para o campo.

A implementação de políticas públicas voltadas para o desenvolvimento do campo, para a qualidade de vida da populaçáo, tem na educação um instrumento fundamental para o processo. Porém, não para a educação que está posta, mas para outra concepção de educaçáo, capaz de atender a heterogeneidade, diversidade, singularidade, complexidade e especificidades do campo.

A luta não para. A constância triunfa sobre a opressão e o esquecimento. A semente plantada através dos primeiros movimentos de luta da história brasileira ainda está viva, embora não esteja tấo visível e pujante. 
A mesma necessidade está na fisionomia do operário, do homem do campo e daqueles que lutam por igualdade, justiça e direitos. Enquanto existir fome, miséria e desigualdades, a luta popular será contínua e constante.

O direito à educação está relacionado com os demais direitos sociais e humanos. Como direito público subjetivo de todos à educação transforma-se num instrumento importantíssimo para afirmar a cidadania, autonomia e a democracia. A história da educação de jovens, adultos e idosos se mistura com o lugar social historicamente reservado aos camponeses, trabalhadores, pobres, negros, subempregados e privados de direitos básicos.

O direito à educação pública, obrigatória e gratuita é recorrente no discurso dos diversos segmentos que compóem a sociedade brasileira no contexto contemporâneo. A sociedade abrange jeitos de ser, viver, perceber, conhecer e pensar que se enfrentam.

Neste contexto, a educação popular de jovens, adultos e idosos do campo, na medida em que afirma a igualdade de todos como sujeitos de direitos quebra a lógica de uns são mais valiosos do que outros. E reforça a necessidade da luta contínua contra as injustiças e o da indignação diante da barbárie.

O legado da Educação Popular permite a construção de práticas pedagógicas emancipatórias na educação de jovens, adultos e idosos no Território do Sisal, fundamental para assegurar a interlocução e parceria nos diversos espaços educativos, principalmente na educação pública para sujeitos que vivem nos municípios sisaleiros.

A luta social pelo direito à educaçáo na vida de mulheres e homens sertanejos sisaleiros certamente contribuirá como força motriz da esperança para todos aqueles que lutam por um mundo melhor.

\section{Referências}

BAUMAN, Zygmund. Tempos líquidos. Rio de Janeiro: J. Zahar, 2007.

BOURDIEU, Pierre. A escola conservadora: as desigualdades frente à escola e a cultura. In: . Escritos de educaçáo. 8. ed. Petrópolis, RJ: Vozes, 1998.

; CHAMPAGNE, Patrick. Os excluídos do interior. In: Escritos de educação. 8. ed. Petrópolis, RJ: Vozes, 1998.

CERTEAU, Michel de. A invençáo do cotidiano: 1: de fazer. Tradução Ephraim Ferreira Alves. 2. ed. Petrópolis, RJ: Vozes, 1996. 
; GIARD, Luce; MAYOL, Pierre. A invenção do cotidiano: 2: morar, cozinhar. Tradução Ephraim F. Alves e Lúcia Endlich Orth. Petrópolis, RJ: Vozes, 1996.

FARIA, Edite Maria da Silva de. A luta social ensina: o direito à educação na vida de mulheres e homens sisaleiros - Assentamento Nova Palmares - Conceição do Coité. 2014. 209 f. Tese (Doutorado) - Departamento de Educação, Universidade do Estado da Bahia, Salvador, 2014.

FARIA, Edite Maria da Silva de. Panorama das Políticas e Propostas de Educaçáo de Pessoas Jovens e Adultas no Brasil: fronteira entre o instituído e o instituinte. In: A Educação de Jovens e Adultos: Questôes Atuais. Curitiba: CRV, 2013, v. 1, p. 103-121.

. O percurso formativo dos professores/pesquisadores da EJA na contemporaneidade. Práxis Educacional. Vitória da Conquista, v. 5, p. 151-164, jul./dez., 2009.

. Educaçáo de Jovens e Adultos do Campo: da estigmatização ao protagonismo. In: Educação do Campo e Contemporaneidade. Salvador: EDUFBA, 2012, v. 1, p. 239-251.

Pluralidade dos sujeitos da EJA: ponto de partida para políticas públicas de Estado? In: Educação, Multiculturalismo e Diversidade. Salvador: EDUFBA, 2010, v.1, p. 213-228.

FREIRE, Paulo. Conscientização: teoria e prática da libertação: uma introdução ao pensamento de Paulo Freire. 4. ed. São Paulo: Cortez \& Moraes, 1980.

. Direitos humanos e educação libertadora. (Conferência de junho de 1988). In: FREIRE, Ana Maria (Org.). Pedagogia dos sonhos possíveis. São Paulo: Ed. da UNESP, 2001.

. Educação: o sonho possível. In: BRANDÃO, Carlos Rodrigues et al. O educador: vida e morte: escritos sobre uma espécie em perigo. 5. ed. Rio de Janeiro: Graal, 1982.

1967.

. Educaçáo como prática da liberdade. Rio de Janeiro: Paz e Terra,

Paulo Freire: da 'pedagogia do oprimido' à 'ecopedagogia'. São Paulo: Ed. Instituto Paulo Freire, 1999 (Cadernos Pensamento Paulo Freire).

Pedagogia da autonomia: saberes necessários à prática educativa. Rio de Janeiro: Paz e Terra, 1998. 
FREIRE, Paulo. Pedagogia da esperança: um reencontro com a pedagogia do oprimido. 4. ed. Rio de Janeiro: Paz e Terra, 1997. cidadão).

Pedagogia da terra. São Paulo: Fundação Petrópolis, 2000. (Brasil

. Pedagogia da tolerância. São Paulo: Ed. UNESP, 2004.

. Pedagogia do oprimido. Rio de Janeiro: Paz e Terra, 1974.

NASCIMENTO, Antônio Dias. Construindo trincheiras em território minado: a educação no movimento sindical dos trabalhadores rurais sob o fogo cerrado da linha dura e do governo da distensão: o caso da Bahia nos idos dos anos de 1972 a 1990. Revista da FAEEBA: educação e contemporaneidade, Salvador, v. 19, n. 34, jul./dez. 2010.

. Os sujeitos da educação do campo e processo civilizatório: subsídios para reflexão. In: DIAS, Adelaide Alves; MACHADO, Charliton José dos Santos; NUNES, Maria Lúcia da Silva (Org.). Educaçáo, direitos humanos e inclusão social: currículo, formaçấo docente e diversidades socioculturais. João Pessoa: Editora Universitária da UFPB, 2009.

SANTOS, Boaventura de Sousa. Construção multicultural da igualdade e da diferença. In: CONGRESSO BRASILEIRO DE SOCIOLOGIA NO INSTITUTO DE FILOSOFIA E CIÊNCIAS SOCIAIS, 7., 1995, Rio de Janeiro. Anais... Rio de Janeiro, 1995.

Produçáo capitalista: os caminhos da produção não capitalista. Rio de Janeiro: Civilização Brasileira, 2002.

. Reinventar a democracia: entre o pré-contratualismo e o póscontratualismo. In: HELLER, Agnes et al. As crises dos paradigmas em ciências sociais e os desafios para o século XXI. Rio de Janeiro. Contraponto, 1999. 


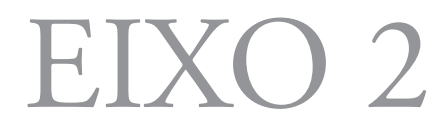

- $\square$

Os jovens e o direito à cidade 


\title{
AS "JUVENTUDES" VÍTIMAS DE HOMICÍDIOS: \\ A CLIVAGEM ETÁRIA, RAÇA/COR E SEXO NA \\ COMPOSIÇÁO DAS MORTES EM PERNAMBUCO \\ E NA BAHIA EM DETERMINADO \\ RECORTE TEMPORAL
}

\author{
Rogéria Martins ${ }^{1}$ \\ Paulo Fraga ${ }^{2}$ \\ Elisabeth Murilho ${ }^{3}$
}

\section{Introduçáo}

Este artigo é fruto de reflexão coletiva de um grupo de pesquisa em consolidação, representado por professores de duas universidades federais mineiras: Universidade Federal de Juiz de Fora e Universidade Federal de Viçosa, os quais vêm otimizando os recursos de pesquisa e atuando em parceria na promoção do debate em torno do tema Juventude. Esse movimento é, sobretudo, um reconhecimento que as opçôes no trabalho coletivo enriquecem a capacidade de atuação e análise, sobretudo, considerando a possibilidade de diálogo interinstitucional que permite maior alcance na reflexão de questóes e na produção de conhecimento. Esse caminho busca sustentar nossas convicçóes investigativas mais profundas, em meio as mais diferentes adversidades que se colocam, principalmente, pelas dificuldades inerentes à produção de trabalhos isolados, sem maiores articulações.

O debate que ora se coloca busca aliar a questáo da violência, desenvolvida em diferentes pesquisas, apresentando os riscos e vulnerabilidades a

1 Socióloga, doutora em Políticas Públicas, professora do Departamento de Ciências Sociais da Universidade Federal de Viçosa - UFV. E-mail: < rogerialma@yahoo.com.br>.

2 Sociólogo, doutor em Sociologia, professor do Departamento de Ciências Sociais da Universidade Federal de Juiz de Fora - UFJF, Diretor do Centro de Pesquisa da UFJF. E-mail: <pcp_fraga@yahoo.com.br>.

3 Antropóloga, doutora em Ciências Sociais, professora do Instituto de Artes e Design da Universidade Federal de Juiz de Fora - UFJF. E-mail: <murilho@gmail.com>. 
que os jovens estão expostos, notadamente, no que concerne a vitimização por homicídios e por tentativas de homicídios. Entretanto, além desse grave problema, busca-se, igualmente, refletir sobre "as juventudes", ou seja, os tipos de jovens, suas diferenças, suas similitudes e as desigualdades que se colocam a cada indivíduo ou grupo devido a sua condição de raça, classe ou gênero.

A literatura já nos aponta essa acepção, de negação de uma perspectiva universalista para a categoria juventude, contudo, os dados aqui apresentados ratificam essa assertiva na literatura e ainda nos revela dados concretos sobre a discussão conceitual do tema. O debate que o artigo se reporta é revelar o efeito nefasto dessas experiências marcadas pelas institucionalidades da existência social desse grupo. O crime de homicídio vem como pano de fundo nesse debate e a questão da discussão conceitual da juventude como foco principal, na medida em que apresenta como determinadas experiências marcam uma trajetória, absolutamente diferenciada a partir dos recursos disponíveis aos quais esses jovens acessam a sociedade. Nesse sentido, desassociam-se da representação aludida aos jovens, enquanto um grupo que se caracteriza pela capacidade de compor uma força social renovadora na sociedade.

\section{Discussão do tema}

A discussão sobre juventude ganha contornos de relevância, considerando o seu componente demográfico, em todo o mundo e seu impacto na formação da sociedade, levando em conta a natureza dessa experiência social. Por outro lado, essa experiência revela um contexto bastante complexo para esse grupo social, uma vez que se torna alvo de eventos violentos fatais, como os crimes de homicídios. Esse evento apontado para a categoria juventude, na sociedade brasileira, nos coloca um grande conflito conceitual, na medida em que permite questionar que experiência é essa? Se em termos conceituais a categoria é universal, temos um problema de ordem prática, pois nem todos os componentes desse grupo social são alvos em potenciais de homicídios. Nesse sentido, a produção de conhecimento do tema exige reflexóes mais elucidativas, do ponto de vista conceitual e teórico, uma vez que se trata de um universo ainda movediço, que exige maior clareza na definição da categoria juventude.

Segundo Mauger (1994, p. 6), o trabalho 
aparentemente inocente, técnico, de constituição e de apresentação de uma bibliografia, de recenseamento de unidades de pesquisa, de pesquisadores e de trabalhos em curso, coloca um primeiro problema clássico: o da delimitação do domínio dos objetos.

Este é um dado que por si só já evoca um problema de ordem metodológica, como afirma Sposito (1997), porque se ponderam duas reflexốes: a exigência de uma definição, ainda que provisória, para delimitar os critérios de seleção do objeto e, de outra parte, para estabelecer essa definiçấo incorre-se nos diferentes usos da categoria juventude, ou seja, segundo Mauger (1994), o impasse está justamente na forma mínima do critério estabelecido para formalização conceitual dessa categoria.

Estudar a juventude é sempre se deparar com uma necessidade de delimitaçóes: falamos de uma faixa etária específica, de um período da vida ou de uma condiçáo social? Como bem formulou Bourdieu (1986), a "juventude é apenas uma palavra", pois juventude e velhice seriam apenas construçôes sociais, e essas denominaçôes se aplicariam a faixas etárias estendidas ou encurtadas segundo os interesses em jogo, dependendo da sociedade e do contexto histórico. A juventude seria então uma "invenção" dos mais velhos para deixar os mais jovens distantes da participação integral na sociedade, principalmente do poder. Assim, esse critério varia segundo o período histórico, a distinção sexual, as classes sociais e a sociedade, pois era importante para determinar a idade para os casamentos e a entrada no mundo do trabalho.

Desde a segunda metade do século XX, no entanto, a juventude tornou-se fase da vida mais valorizada, tendendo a se estender para muito além de seu limite biológico. Isto porque, após séculos de desvalorização do jovem, ao qual eram atribuídas características negativas (intempestivo, apaixonado, desmedido, excessivo), a "revoluçáo juvenil" dos anos 60 promoveu uma inversáo, transformando a juventude num valor social e cultural. Ela é, assim como os outros grupos sociais, "o encontro das construçóes e representaçóes sociais com as condiçóes de vida, as experiências e as identidades nas quais os indivíduos se reconhecem e agem", segundo Dubet (1994, p. 1), ou seja, assim como a classe operária ou os estudantes, a juventude é uma categoria construída e vivida socialmente e, assim como as demais, é também transitória. A composição de sua trajetória marca, em efeitos bem delimitados, a expectativa que se atribui aos componentes desse 
grupo - enquanto a representação de um modo de ser, suas perspectivas institucionais são marcadas, em geral, por um pragmatismo obtuso na sociedade, conforme se pode observar em Augusto (2005, p. 20):

A mesma sociedade pode produzir tipos de jovens bastante diversos, pois, originados de diferentes extraçóes sociais, inserindo-se em posiçôes distintas e apropriando-se de hábitos e valores específicos de acordo com essa inserção, as "maneiras de ser" que lhes são impostas - ou que têm possibilidade de constituir - não são as mesmas para todos. Na distribuição diferencial que forçosamente ocorre, uns são mais privilegiados do que outros. Desse modo, fica claro que a juventude não é una, e que a diferenciação social e a diversidade econômica têm peso importante na configuração das distintas "maneiras de ser" impostas aos jovens.

Foracchi (1972) considera que, não sendo possível uma delimitação etária, a juventude representa histórica e socialmente uma categoria elaborada pelas tensóes próprias à crise do sistema. $\mathrm{Na}$ concepção da autora, a categoria representa um modo de realização da pessoa, um projeto de perspectivas institucionais, uma nova configuração de existência social. A autora também caracteriza a juventude considerando a sua existência social enquanto fonte de potencial força social renovadora. Nesse sentido, mais uma vez temos que relativizar essa acepção, na medida em que se considera que a percepçáo da sociedade sobre essa perspectiva positiva para os jovens não é uníssona. Para determinados jovens, na sociedade, a sua caracterização vem envolvida de uma percepçáo estigmatizada, negativa, logo destituída desse potencial renovador. Pelo contrário, as expectativas que se voltam para uma determinada juventude revelam-se fadadas ao fracasso e à morte, destituída de qualquer força social. Bom, isso nos permite questionar de que juventudes, então, falamos? Que juventudes são essas que se compóem por trajetórias diferenciadas: enquanto uma é composta por expectativas positivas, constituída por uma força social renovadora, conforme sinaliza Foracchi (1972) e outra composta por expectativas negativas, aludidas por um processo de perda substancial de sua própria existência. Entender a especificidade de ser jovem e compreender a desigualdade dessas trajetórias e, dessa forma, compreender os horizontes que as políticas públicas podem e devem atuar, porque revela elementos potenciais de desigualdade. Os dados da pesquisa sobre homicídios em Pernambuco e na Bahia são apenas um exemplo desse contexto desigual, o qual se aplica a trajetória de determinadas juventudes. 
As transformaçóes operadas na contemporaneidade têm imposto desafios para compreender essa categoria, uma vez que são reconhecidas as diferentes inserçóes dos jovens na sociedade, no que tange às dimensóes históricas, sociais e culturais. Ser jovem implica identificar, então, uma suposta faixa etária, o contexto social em que vive e suas idiossincrasias. Se, conceitualmente, os limites estáo colocados pelas implicaçôes que a categoria estabelece nos contextos sociais; por outro lado, a sua conformação pelas instituições sociais é realizada à revelia dessa indisposição conceitual, sob o crivo direto das representaçóes que os operadores aplicam ao sentido da juventude. Por isso, muitos autores (QVORTRUP, 2000; GROPPO, 2000; ALANEN, 2001; MAYALL, 2002) consideram o termo geração uma categoria estrutural importante na análise dos processos de estratificação social e nos dispositivos das construçóes das relaçóes sociais (SARMENTO, 2005). É sempre muito bom lembrar essa dimensão reveladora na sociedade em que pese às formas de pensar para esse grupo social. Segundo Novaes (2006), jovens com idades iguais vivem juventudes desiguais, porque possuem experiência social diferente em seus contextos históricos, sociais e culturais. Portanto, a uniformização conceitual da categoria alude-se a uma distensão do real. Velho (2006) nessa mesma tentativa de explicar o conceito, também reconhece a dificuldade de qualificar juventude, dentro de uma perspectiva universal.

Isso reforça a ideia de que a compreensão da contemporaneidade deve estar atenta às concepçóes que grupos sociais são categorizados, o grupo social concreto (MANNHEIM, 1968) para reconhecer suas experiências e sociabilidades específicas, para não incorrer em camuflagens ideológicas das estratificações sociais. Segundo Foracchi (1972), as trajetórias possíveis desse grupo são estabelecidas socialmente, onde cada sociedade impóe um modo de ser dessa juventude, logo, revela sua existência social a partir de sua própria imagem. Essa imagem se revela potencializadora ou não, acometida pelos recursos e potencialidades que se atribui a constituição desse grupo, de sua institucionalidade fruto da disposição que a sociedade lhe atribui. Estamos falando aqui das alternativas, das oportunidades nessas trajetórias sociais que são oferecidas de forma, absolutamente, desigual na sociedade brasileira. As clivagens de raça/cor, sexo e faixa etária são variáveis que revelam essa desigualdade.

Reconhecemos que tais clivagens demandam desigualdades nas formas como os jovens são identificados e vivem sua juventude. Essas clivagens ocorrem em qualquer espaço geográfico, pois estáo presentes em 
muitos países, logo não é prerrogativa nacional. Contudo, no caso específico do Brasil, a forma como ocorrem os homicídios contra jovens de bairros periféricos de grandes e médias cidades possui a sua especificidade, sobretudo, em parte pelo desvelo atribuído a essas mortes. Não iremos discutir essas diferenças regionais ou internacionais, pois foge dos objetivos deste texto, mas reafirmamos que as formas como determinadas sociedades lidam com a questão são preponderantes significativos a partir de suas taxas de homicídios acometidas a determinados jovens.

Ainda que Mannheim, enquanto autor importante nesse debate, defenda a corrente geracional que evoca a composiçáo de elementos constituintes de uma mesma fase de vida e, dessa forma, com elementos etários definidos na perspectiva de uma cultura juvenil; Bourdieu (1986) também apresenta uma interpretaçáo, denominada de classista, uma vez que a juventude é tomada como um grupo necessariamente diversificado, em razão de suas pertenças de classe. Foracchi (1972) contribui de forma prestigiosa com sua interpretação da categoria, ao identificar não só esse componente classista, como marca um campo de atuação dotado de institucionalidades, bem como a representação de uma existência social a qual sua trajetória estará marcada pelos recursos disponíveis que o Estado vai permitir que esse grupo acesse. A questão que se apresenta é o modo como, recorrentemente, esses atores são revestidos em seus papéis sociais, desenvolvendo práticas diferenciadas de uma determinada classe etária, em cada contexto social particular. Esse construto envolve implicaçóes mútuas na categoria juventude.

\section{Metodologia das pesquisas}

A reflexão que se seguirá deu-se em determinado período, mas o que se pretende neste trabalho é justamente fazer uma análise do evento em um tempo específico, independente de ser recente ou mais longínquo. A ideia é refletir sobre a incidência do homicídio, levando em consideração suas características.

$\mathrm{Na}$ direção dos estudos que buscam compreender o fenômeno a partir de suas perspectivas ecológicas, o presente artigo analisa o incremento dos homicídios no estado da Bahia e em Pernambuco, Brasil, a partir da aferição do incremento das taxas de homicídios em todos os municípios que compóem esses respectivos estados nordestinos. Os resultados a serem 
apresentados são parte integrante das pesquisas: Homicídios nos Municipios Baianos de 1991-2002: uma análise descritiva e Homicídios em Pernambuco (1990-2003): uma análise descritiva de Eventos Violentos, ambas coordenadas pelo prof. Paulo Fraga e financiadas pelo CNPq. O estudo original compreendia os anos de 1991 a 2002, bem como 1990-2003. No entanto, nessa comunicação, o recorte temporal foi realizado para os anos compreendidos entre 1996 e 2007. Optou-se por atualizar os dados com informaçóes de anos mais recentes, o que proporciona um retrato mais atual do fenômeno e porque tal procedimento permite trabalhar apenas com a Revisão X da Classificação Internacional de Doenças (CID).

A frequência de homicídios foi trabalhada para a população total, por grupo de sexo, por faixas etárias e por raça/cor, conforme categoria estabelecida pelo Banco de Dados do Sistema de Informaçáo de Mortalidade do DATASUS. A organização das frequências de óbitos foi realizada por local, segundo sua distribuição de ocorrência e não de residência, pela importância que a primeira categoria tem para a política de segurança pública.

Os estudos de corte ecológicos se caracterizam pelo emprego de indicadores de exposição agregados, com definição da unidade de análise. Como observa Hennekens (1987), nos estudos de problemas de saúde, entre os quais os homicídios, a abordagem ecológica constituiu-se um primeiro e importante passo, no sentido de informar os agravos de saúde, as relações que se estabelecem entre a variável e fatores outros de exposição que podem ser avaliados para o levantamento de hipóteses causais e sua distribuição espacial. Esta questão tem sido levantada por pesquisadores que vêm se dedicando à temática. Cano (2000), ao realizar pesquisa sobre indicadores de criminalidade no Rio de Janeiro, observou que os dados das polícias apresentam inúmeros problemas, tais como: falta de padronização entre as categorias em anos diferenciados; informaçóes duplicadas por departamentos distintos de polícias; inexistência de dados sobre características das vítimas, dos agressores e dos atos delituosos; ausência de padrão nos procedimentos de coleta de informaçóes e nas categorias utilizadas entre unidades diferentes, e um número bastante alto de subnotificação. Cardia et al. (2003) também atentaram para o fato de que no decorrer dos procedimentos investigativos e judiciais pode ocorrer a categorização diferente do mesmo evento.

Outro problema que dificulta a utilização de informaçôes policiais para monitorar atividades criminais ou violência no Brasil, é que os dados policiais publicados fornecem informaçóes apenas sobre o número 
de eventos criminais, mesmo quando envolvem mais de uma vítima ou agressor. Desta forma, um homicídio múltiplo, tal como uma chacina, é considerado como um caso apenas, independente do número de vítimas (CARDIA et al., 2003).

De outro modo, apesar de o Sistema de Informação de Mortalidade - SIM apresentar problemas como um número significativo de dados indeterminados ou não identificados para algumas categorias, há um processo de homogeneizaçáo dos dados que vem sendo empregado pelo Ministério da Saúde às secretarias municipais e estaduais de saúde que têm facilitado estudos epidemiológicos e sociais com estes dados. Nesse sentido, nos últimos anos, vários ajustes têm sido feitos visando à diminuição de subnotificaçóes e indeterminaçóes.

Ainda que os dados apresentados não sejam absolutamente atuais ${ }^{4}$, eles revelam um quadro sintomático para a categoria juventude e vêm ser objeto de análise neste trabalho, tendo em vista o enriquecimento das afirmaçóes elaboradas por estudiosos do tema.

\section{Dados da pesquisa}

A Organização Mundial de Saúde estima que, aproximadamente, 1,6 milhóes de pessoas morrem a cada ano, em decorrência da violência. Esta se encontra entre as principais causas de óbito na faixa etária de 15 a 44 anos no Brasil e, na maioria dos países, corresponde a $14 \%$ dos óbitos no sexo masculino, e a $7 \%$ dos óbitos no sexo feminino.

Em alguns trabalhos, algumas causas têm sido citadas: a possível associação das altas taxas de homicídios com o processo de urbanização, desigualdades socioeconômicas, pobreza, tráfico de drogas, enfretamentos raciais e étnicos, mudanças na estrutura familiar, conflitos armados, autos de resistências e violência policial entre outros fatores (SOUZA, 1994). No entanto, devemos ter muito cuidado com as afirmaçóes que atrelam o aumento dos homicídios a fatores como a pobreza. Existe uma larga discussão na literatura sociológica brasileira e mundial, que critica esses tipos de abordagens.

4 Para efeito deste artigo, o presente trabalho é fruto de reflexão sobre um dos temas do Encontro dos Pesquisadores e Pesquisadoras de Políticas de Juventude - Participatório em Rede, baseado em pesquisas já realizadas. 
No Brasil, o índice de homicídios perpetrados por agentes policiais é considerado, também, muito alto para os padrôes internacionais e tem sido alvo de preocupação de estudiosos (CANO, 2000), por ter participação nos homicídios em geral e pela dificuldade de se mensurar sua real dimensão, pois ficam subsumidos nas estatísticas deste tipo de evento pela forma como são registrados. A abordagem da violência como um problema do campo da saúde pública visa analisar sua classificação e distribuição geográfica e, concomitantemente, identificar os seus determinantes sociais, sobretudo compreender porque tantos jovens morrem no Brasil. O limite da utilizaçáo das fontes relativas ao setor saúde é por apresentar, apenas, os dados da vítima, tipo de ferimento e de instrumento utilizado, não contendo informaçóes sobre o agressor. Nesse sentido, a pesquisa não nos permite estabelecer associaçóes e explicações conclusivas, mas revela quem são essas vítimas; quais as suas características. Desse modo, ela aponta a necessidade de açôes institucionais, através de políticas públicas, para promover ajustes contundentes para proteger e garantir os direitos dessas vítimas. Ainda que esse contexto mereça maior investimento do Estado para com esses grupos sociais.

A literatura avança, mostrando que o estudo sobre os homicídios por arma de fogo no Brasil (TOURINHO, 2004), na maioria dos estados brasileiros, é o principal instrumento utilizado nos homicídios. Esta causa está diretamente ligada a determinados fatores como o aumento da criminalidade e pela facilidade de acesso às armas pela população. Tourinho (2004) alerta, ainda, que a violência por armas de fogo é resultante da complexa e dinâmica interação de múltiplos fatores que incluem determinantes de âmbito individual, relacional, comunitários, político e social. Isso recrudesce ainda mais o estado de ser dessas vítimas que, antes mesmo de serem acometidas pelo crime de homicídio, estão imersas num contexto de extrema violência.

Nesse sentido, as políticas multisetoriais e integradas necessitam estar centradas na diversidade de causas que influenciam o aumento das taxas de homicídios e que passam pela adoção de medidas estruturais para a redução das desigualdades; diminuição da impunidade e reforma dos sistemas policial, judiciário, penitenciário, visando à reduçáo do sentimento de insegurança da população e que é responsável pela demanda de mecanismo privados de segurança, que funcionam, muitas vezes, à revelia da lei, reproduzindo a violência que anunciam evitar e combater (TOURINHO, 2004). 


\section{Em Pernambuco}

Se analisarmos a frequência dos homicídios por arma de fogo no período, levando em consideração os anos extremos da série, é possível observar que a participaçáo percentual dos homens no total dos eventos aumentou de 93,55\%, em 1996, para 94,82\%, em 2007, em Pernambuco. O ano de 2001, entretanto, tal como ocorreu para os homicídios, em geral, é o ano em que houve a maior participação percentual masculina no total dos homicídios por arma de fogo. Beato Filho e Marinho (2007), em seu estudo, observam que a taxa de homicídios envolvendo armas de fogo no Brasil é maior entre os homens, jovens, do que em qualquer outro grupo. No caso específico do estado de Pernambuco, a participação percentual de homens no total de homicídios é significativa e expressa a tendência do fenômeno se concentrar nesse grupo de gênero.

A variável raça/cor é utilizada, também, como importante indicador do caráter de seletividade dos eventos de homicídios. Somente a partir de 1996, a variável raça-cor é incluída no SIM. Nesse ano, a subnotificação é altíssima, quase $100 \%$, por isso, não foi incluída na análise. É a partir de 2001 que os dados apresentam um número menor de cor ignorada da vítima do homicídio. É importante observar que a cor parda é aquela onde há maior número de vítimas, excetuando a categoria ignorada em todos os anos da série, sendo que em 2007, ela representa $91 \%$ das vítimas de homicídios no estado de Pernambuco. Sabe-se que a categoria parda é extremamente ambígua, pois, em sua maioria, está incluída uma parte significativa da população afrodescendente.

Em relaçáo aos grupos etários mais vulneráveis aos eventos de homicídios, não é novidade que os jovens são o grupo mais exposto. Como revela o estudo de Tourinho (2004), que compreende os anos de 1980 a 2002, neste período, 110.320 crianças e adolescentes, de 0 a 19 anos, foram vitimadas fatalmente por agressão. Em Pernambuco, a faixa etária mais vitimada no período foi aquela que compreende as idades de 20 a 29 anos, quando em todo o período, foram vitimadas 21.092 pessoas; seguida da faixa etária de 30 a 39 anos, com 11.129 vítimas e de 10 a 19 anos, onde 8.966 pessoas morreram. Se levarmos em conta os anos extremos da série, observa-se que houve um crescimento maior na faixa etária de 10 a 19 anos, em relação às outras duas. Enquanto esta faixa cresceu 94\%, a faixa de 20 a 29 cresceu $71 \%$ e a de 30 a 39 incrementou, nas extremidades do período, $34,45 \%$. 
No ano de 1996, o estado de Pernambuco registrou 3.022 mortes por homicídios. As cidades com mais de 20.000 habitantes foram as que apresentaram as maiores taxas destacadas. Floresta se destaca como a cidade que apresenta a maior taxa e a mesorregião na qual a cidade está inserida, a do São Francisco, é aquela que possui o maior número de municípios entre aquelas que apresentam as maiores taxas, totalizando três cidades. As mesorregióes do Sertão, Região Metropolitana e Agreste vêm em seguida, com dois municípios cada. Em relação às microrregiôes, a de Petrolina se destaca com dois municípios. As taxas são muito altas, todos os dez municípios apresentam taxas acima de 50/100.000, índices que se apresentavam entre os mais altos do país no período.

\section{Na Bahia}

Como observa Soares Filho (2011), há diferenças notáveis de risco de morrer pelo evento do homicídio entre brancos e negros no Brasil, mesmo quando está sob controle a taxa de escolaridade do indivíduo. A expectativa de vida de homens e mulheres negras é menor se comparada com pessoas brancas dos sexos masculino e feminino. Na capital baiana, cidade com uma alta presença de população negra em sua composição, os indivíduos desse grupo racial morrem em idades menores e perdem 12,2 vezes mais anos potenciais de vida, em razão dos homicídios do que os brancos.

$\mathrm{Na}$ Bahia, somente a partir dos anos de 2005, as informaçóes sobre homicídios segundo raça/cor passaram a ser mais confiáveis, com menor subnotificação. O grupo de pessoas consideradas preto/pardo representou, entre 2003 e 2005 , cerca de $85 \%$ do total dos homicídios. Agregados na categoria negro, eles representam o grupo mais vulnerável ao evento de homicídios.

O abreviamento da vida na juventude está na faixa etária com a maior frequência de homicídios e é aquela que compreende as idades entre 20 e 29 anos. Na série histórica de 1998 a 2007, os adolescentes entre 15 e 19 anos aparecem como a terceira faixa etária em número de homicídios. No entanto, se levarmos em consideração as taxas de homicídios, a faixa de 15 a 19 aparece em segundo lugar, abaixo, apenas, da faixa entre 20 e 29 anos.

No ano de 2007, para a faixa etária de 15 a 19 anos, algumas cidades baianas apresentaram índices significativamente altos. Das dez cidades com mais de 20.000 habitantes, três estavam localizadas na microrregião de Salvador e duas na microrregião de Ilhéus-Itabuna. 
Se observarmos a evolução das taxas de homicídios entre os anos de 2000 a 2007, para a populaçáo de 15 a 19 anos, podemos perceber que houve um aumento significativo de municípios que tiveram índices acima de 50/100.000, entre os anos extremos da série histórica. Outra característica importante na evolução do incremento das taxas para a faixa etária é o fato de no ano 2000 existirem 363 municípios no estado que tinham taxa zero para a referida população. No ano de 2007, embora ainda a maioria dos municípios continuasse apresentando taxa zero de homicídios, o número cai para 333, e a maior taxa que em 2000 era de 146/100.000 passou, em 2007, para 232/100.000.

As taxas gerais de mortalidade para a população, em geral, aumentaram significativamente ao longo do período estudado, a faixa etária entre 15 e 19 anos foi uma das mais atingidas pelo evento.

As características da alta das taxas de homicídios que se concentram em alguns municípios baianos e que aumentaram nos últimos anos, principalmente em cidades da Regiáo Metropolitana de Salvador e em cidades de porte médio interioranas, mas com grande concentração urbana, como Itabuna, destacam a questão do risco e da vulnerabilidade que os jovens da periferia, geralmente negros, estão submetidos. Os dados mostram, também, que a maioria dos eventos foi praticada nas áreas periféricas das cidades.

A esse respeito Ruotti, Massa e Peres (2011) chamam a atenção para a urgência de uma abordagem do fenômeno da violência que supere àquela centrada no risco, que permita compreender o estigma que recai sobre determinados jovens, e os efeitos específicos que isso pode produzir e que podem levá-los a desfechos violentos. O que as autoras enfatizam é a necessidade das análises de vulnerabilidade de considerar tanto os perigos ou eventos hostis que podem afetar uma determinada população, principalmente, os jovens das periferias urbanas, quanto à fragilidade desses em enfrentar os eventos violentos. Esse procedimento, segundo as autoras, pode auxiliar na compreensão de processos culturais e sociais envolvidos nas situaçóes de violência, bem como entender as formas como os jovens lidam e enfrentam, assim como o sentido que eles as atribuem.

Nesse sentido, complementam as autoras, um dos desafios dos estudos é entender os significados da exposição de jovens à situação de risco que os aproximam da possibilidade de terem suas vidas ceifadas precocemente, como consequência dos processos de socializaçáo que os empurram para atividades ilegais. O risco e a vulnerabilidade devem ser analisados em um processo mais amplo como consequência de trajetórias de vidas moldadas na relação com situaçóes estruturais (FRAGA, 2003). 


\section{Consideraçóes finais}

Embora o estudo não tenha se aprofundado nas causalidades do aumento dos homicídios, as formas como são cometidos esses crimes, com armas de fogo, em sua maioria, em cidades onde a maioria das vítimas reside em bairros da periferia das áreas urbanas, apontam para a necessidade de compreender os eventos como similares aos que há mais tempo em outras regióes metropolitanas, como Rio de Janeiro e São Paulo. Se nestas cidades tem havido uma diminuição, ainda que haja recorrência do evento, em cidades baianas, como aquelas localizadas na Região Metropolitana de Salvador, os eventos aumentaram. Por outro lado, Pernambuco se destaca no país como o estado com a maior taxa de homicídios. Em relação aos grupos etários mais vulneráveis aos eventos de homicídios, não é novidade que os jovens são o grupo mais exposto. Se levarmos em conta os anos extremos da série, nesse estado, observa-se que houve um crescimento maior na faixa etária de 10 a 19 anos, em relação às outras duas. Enquanto essa faixa cresceu $94 \%$, a faixa de 20 a 29 cresceu $71 \%$ e a de 30 a 39 incrementou, nas extremidades do período, 34,45\%. Se juntarmos os dois grupos que compóem a faixa etária reconhecida como jovem, de 15 a 29 anos, temos um percentual ainda maior. Esse é um dado significativo para a situação dos jovens no Brasil. O enfrentamento requer políticas públicas eficientes e focadas na população juvenil, a mais vulnerável, conforme os dados revelam.

Isso posto, para efeito do trabalho que ora se apresenta, considera-se que o efeito classista da categoria juventude é estruturador para compreender os processos de estratificação social, nos quais podem revelar os efeitos de classe, gênero e raça em que esses grupos estão imbricados. Nas sociedades dinâmicas, como a contemporânea, o efeito da transitoriedade das geraçóes está inscrito nas possibilidades dos processos de mudanças sociais, contudo o efeito seletivo dos eventos de homicídios revela que parte da juventude brasileira está sendo assassinada de forma acentuada e esses jovens, em suas trajetórias individuais, perdem a possibilidade de adquirir força social.

É em Bourdieu (1986) que o trabalho aqui exposto encontra maior amparo, enquanto interlocutor da corrente conceitual classista. Bourdieu (1986) revela maior legitimidade conceitual às análises empíricas deste estudo, pois procura considerar os contextos diferenciados das condiçóes econômicas, as diferentes parcelas de poder e os interesses em 
jogo; conferindo a categoria juventude universos sociais que não parecem homogeneizar esses grupos etários. Por outro lado, é em Foracchi (1972) que se tem a oportunidade de interpretar esses dados sobre homicídios de jovens, na sua maioria de sexo masculino, negros marcados por uma existência social, aludidos dentro de componentes institucionais próprios, que ganham contornos mais extensos para compreender o fenômeno da desigualdade composta nessa existência.

Esta discussão ganha contornos mais práticos, neste trabalho, na análise conjuntural que a aplicaçáo do conceito juventude se coloca, na medida em que busca compreender como os efeitos da clivagem etária, raça/ cor e sexo como a inscrição à desigualdade para a categoria juventude se projeta e se estende, paulatinamente, na sociedade brasileira.

Segundo Foracchi (1972), a juventude revela como a categoria é inscrita pelas tensôes próprias na crise do sistema. Se considerarmos a questão dos homicídios como uma vertente dessa configuraçáo conflituosa da sociedade, temos aqui uma representação bastante complexa da composição dos jovens na sociedade brasileira. Se para a autora, a juventude representa uma nova configuração de existência social; o quadro de violência inscrito para a categoria revela uma nefasta configuração da existência social dos jovens brasileiros - figuras potencializadas pela vitimização da prática de homicídios.

\section{Referências}

ALANEN, L. Explorations in gerational analysis. In: ALANEN, L; MAYALL, B (Org). Conceptualizing child-adult relations. London: Routldge, 2001.

AUGUSTO, M. H. O. Retomada de um legado intelectual: Marialice Foracchi e a sociologia da juventude. Tempo Social, v. 17, n. 2, novembro de 2005.

BEATO, F. C. C; MARINHO, F. C. Padrōes regionais de homicídios no Brasil. In: CRUZ, da Marcus Vinicius Gonçalves; BATITUCCI, Eduardo Cerqueira.

Homicídios no Brasil. Rio de Janeiro: Editora FGV, 2007.

BOURDIEU, P. De quoi parle-t-on- quand on parle du 'problème de la jeunesse?' In: PROUST, François (Org.). Les jeunes et les autres: contributions dês sciences de l'homme à la question des jeunes. Vaucresson: CRIV, 1986. 
CANO, I. Registros Criminais da Polícia no Rio de Janeiro: problemas de confiabilidade e validade. Fórum de Debates: Criminalidade, Violência e Segurança Pública no Brasil: uma discussáo sobre as bases de dados e questóes metodológicas. Rio de Janeiro: IPEA, 2000.

CARDIA, N. et al. Homicídio e violação dos Direitos Humanos em São Paulo. Estudos Avançados. São Paulo, n. 17, v. 47, p. 43-73, 2003.

DUBET, F. Sociologia da Experiência. Lisboa: Instituto Piaget, 1994.

FRAGA, P. C. P. Homicídios nos Municípios Baianos de 1991-2002: uma análise descritiva. Relatório de pesquisa, 2009.

Da Favela ao Sertão: Juventude, Narcotráfico e Institucionalidade In: FRAGA, P.C.P.; IULIANELLI, J.A. Jovens em tempo real. Rio de Janeiro: DP\&A, 2003.

Homicídios em Pernambuco (1990-2003): Uma Análise descritiva de Eventos Violentos. Relatório de Pesquisa, 2009.

FORACCHI, M. A juventude na sociedade moderna. São Paulo: Livraria Pioneira, 1972.

GROPPO, A. L. Juventude: ensaios sobre sociologia e história das juventudes modernas. Rio de Janeiro: DIFEL, 2000.

HENNEKENS, C.H. et al. Epidemiology in Medicine. Boston: Little, Bowon \& Co, 1987.

MANNHEIM, K. O problema da juventude na sociedade moderna. In:

BRITTO, S. Sociologia da Juventude I: da Europa de Marx à América Latina de hoje. Rio de Janeiro: Zahar Editores. 1968.

MAUGER, G. Les jeunes en France: état dês recherches. Paris: La documentation française, 1994.

MAYALL, B. Towards a sociology for childhood: thinking from children's lives. Buckingham: Open University, 2002.

NOVAES, R. Os jovens de hoje: contextos, diferenças e trajetórias. In: ALMEIDA, M. I. M. de; EUGENIO, F. (Orgs.). Culturas jovens: novos mapas do afeto. Rio de Janeiro: Jorge Zahar Ed., 2006. 
QVORTRUP, J. Generations an important category in sociological research. In: Congresso Internacional dos Mundos Sociais e Culturais da Infância, Braga, 2000, Actas... Braga; Universidade do Minho, Instituto de Estdos da Infância, v.2, 2000 .

RUOTTI, C; MASSA, V.; PERES, M. F. T. Vulnerabilidade e violência: uma nova concepção de risco para o estudo dos homicídios de jovens. Interface (Botucatu). 2011, vol. 15, n. 37, 2011.

SARMENTO, M. J. Gerações e alteridade: interrogaçóes a partir da sociologia da infância. Revista Educaçáo e Sociedade. Campinas, v. 26, n. 91, p. 361-378, mai./ago., 2005.

SOARES FILHO, A. M. Vitimização por homicídios segundo características de raça no Brasil. Rev. Saúde Pública [online]. 2011, vol.45, n. 4, p. 745-455. Epub, 01-Jul-2011.

SOUZA, E. R. Homicídios no Brasil: o grande vilão da saúde pública na década de 80. Cadernos de Saúde Pública, v. 10, n.1, p. 45-60, 1994.

SPOSITO, M. P. Estudos sobre Juventude e Escolarização. In: Juventude e contemporaneidade. Revista Brasileira de Educação, São Paulo, n. 5/6, p. 37 52, mai.-ago./set.-dez.1997. (Edição Especial)

TORINHO, M. F. Mortalidade por armas de fogo no Brasil: 1991 a 2000. Brasília: Ministério da Saúde, 2004.

VELHO, G. Epílogo - juventudes, projetos e trajetórias na sociedade contemporânea. In: ALMEIDA, M. I. M. de; EUGENIO, F. (Orgs.). Culturas jovens: novos mapas do afeto. Rio de Janeiro: Jorge Zahar Ed., 2006. 


\title{
VARAS DA INFÂNCIA E JUVENTUDE: UMA ANÁLISE DAS COMPETÊNCIAS CONCORRENTES E A MASCULINIZAÇÃO JUDICIÁRIA NA JUDICIALIZAÇÁO DOS CONFLITOS NA BAHIA E EM MINAS GERAIS ${ }^{1}$
}

\author{
Rogéria Martins ${ }^{2}$
}

\section{Introduçáo}

A discussão sobre infância e juventude ganha contornos de relevância, considerando o seu componente demográfico, em todo o mundo, e seu impacto na formaçáo da sociedade, levando em conta a natureza dessa experiência social. Por outro lado, essa experiência revela um contexto bastante complexo para esse grupo social, uma vez que os conflitos envolvendo crianças e adolescentes têm adquirido contornos controversos no âmbito dos tribunais ${ }^{3}$, em razão da característica de uma cultura judiciária que impacta diretamente a prestação jurisdicional.

O drama social no que tange as delinquências e sofrimentos juvenis, por si só coloca esse corpo profissional numa maior exposiçáo, na medida em que a sociedade se coloca, parte dela, de forma controversa no processamento da garantia desses direitos. Esse elemento por si coloca os magistrados no centro

1 O presente texto foi produzido a partir das reflexóes de duas pesquisas coordenadas pela autora, destacam-se: A justiça da juventude: estudo da sentencing na sociobiografia de magistrados da Zona da Mata mineira, financiada pela FAPEMIG - biênio 2014/1016 e As microlitigiosidades da atividade adjudicante nos crimes de estupro: um estudo da sentencing de um tribunal do interior da Bahia, fruto da tese de doutoramento da autora, defendida em 2011.

2 Socióloga, doutora em Políticas Públicas, professora adjunta III, do Departamento de Ciências Sociais da Universidade Federal de Viçosa/MG. E-mail: <rogerialma@yahoo.com.br>.

3 Registra-se que o termo tribunais adotado aqui aos órgãos jurisdicionais de primeira instância da justiça estadual (juízo das varas e/ou comarcas, no âmbito da Primeira Instância). A categoria está mais atrelada aos órgáos jurisdicionais, em geral, como representação do âmbito jurídico das instituiçôes sociais de responsabilização. Alude-se à categoria sinônima, com a mesma concepção os "sistemas jurídicos". 
do campo analítico, uma vez que seus comportamentos, suas decisóes e as motivaçôes manifestas dessas cumprem revelar variáveis das condicionantes jurídicas; e o conjunto de elementos que configuram o perfil das estruturas das varas, no âmbito da justiça estadual. Nesse sentido, a finalidade principal, neste trabalho, foi traçar o perfil dessa cultura judiciária nesses contextos regionais, assim como registrar os impactos da aglutinação de várias especialidades jurídicas e a sub-representação feminina na estrutura judiciária que cerca as varas da infância e juventude da realidade brasileira - aqui explorando particularmente a BA e MG, mais precisamente comarcas da Zona da Mata mineira.

Para uma investigação dessa natureza, o corte metodológico sofreu algumas limitaçóes de escala local/regional, para configurar maior disposição ao investimento empírico que a pesquisa desempenhou. A cobertura da cultura jurídica do universo de varas especializadas, no estado de Minas Gerais, foi significativamente ampla, de modo que se optou por uma região específica do Estado, para essas especialidades ${ }^{4}$. E o resgate da pesquisa $A s$ microlitigiosidades da atividade adjudicante nos crimes de estupro: um estudo da sentencing de um tribunal do interior da Bahia ${ }^{5}$, concluída em 2011, foi favorecida em razão das semelhanças a que foram observadas e, dessa forma, recuperadas aqui, para ampliar nosso campo de percepção sobre os tribunais do interior. Dados secundários foram, também, recuperados para uma análise quantitativa, considerando o relatório recente do Justiça em Número/2016 - ano base 2015; bem como uma revisão bibliográfica temática, que ajudou na análise final deste trabalho. Thomson e Zingraff (1981) sinalizam para a importância de se contextualizar, para afirmar que os resultados se garantem no contexto específico que o objeto está sendo investigado.

4 Relatório de pesquisa: A justiça da juventude: estudo da sentencing na sociobiografia de magistrados da Zona da Mata mineira, financiada pela FAPEMIG - biênio 2014/1016.

5 A referida pesquisa encontra-se publicada na íntegra com algumas alteraçôes na publicação: MARTINS, Rogéria. Estupro de crianças e adolescentes e a desigualdade dos tribunais: uma análise de processos judiciais. Saarbrückken, Editora Novas Ediçôes Acadêmicas, 2013. 


\section{Estatuto da Criança e do Adolescente - ECA}

Com a entrada em vigor da Lei. n. 8.069/1990 com o Estatuto da Criança e do Adolescente - ECA, uma mudança de paradigma se colocou no tratamento de crianças e dos adolescentes nos tribunais. O legislador enxergou a necessidade de despender especial atenção a esse grupo, prezando sempre pela observância do princípio do melhor interesse da criança e do adolescente.

Isso posto, a administração dos conflitos nessa ordem social revela também um processo de democratização da administração da justiça, quando mostra maior disposição para um envolvimento e participação desses profissionais com o contexto social que reclama direitos específicos. Esse investimento pode ser caracterizado pela simplificação dos atos processuais, incentivo de conciliação das partes, e, sobretudo, com o marco jurídico de proteção integral a determinados grupos sociais: crianças e adolescentes. Essa característica de investidura de atribuição de responsabilidade por algum fato a esse grupo reage a dinâmicas complexas dentro e fora do "mundo jurídico" e, por isso, merece atenção especial neste trabalho.

A parte teórica central da pesquisa se concentra no estudo da sentencing. Sobretudo, na busca pelos determinantes da decisão, os fatores que podem influenciar o processo de decisão judicial. Esta teoria, segundo Vanhamme e Beyens (2007), se caracteriza por um vasto campo de pesquisas empíricas sociocriminológicas, focado nas disparidades das penas, a partir da tomada de decisão do julgamento penal. Esses trabalhos vêm sendo desenvolvidos em diferentes países, na Europa (França, Holanda e Inglaterra) e na América do Norte (EUA e Canadá). Sua maior contribuição teórica está na desmistificação da ideia da imparcialidade na tomada de decisão dos magistrados e na observância da desigualdade no direito criminal. $\mathrm{O}$ estudo da abordagem sociológica da sentencing tem mobilizado pesquisadores e fomentado debate internacional, na orientação de uma análise holística na contextualização da tomada de decisão do judiciário na aplicação de sentenças, uma vez que dimensiona o contexto social do processo decisório manifestado por esses atores. A sociologia jurídica inscrita nessa abordagem inventaria, segundo Vianna et al. (1997), as tendências existentes entre o perfil da magistratura e a democratização da prática adjudicante e do próprio Poder Judiciário, relacionando com os elementos da cultura jurídica. Nesse sentido, estudos que viabilizam o universo característico da formação de um corpo profissional estabelecem 
um marco valorativo sedimentado que incide numa explicação conceitual e metodológica na função social dos tribunais.

Contudo, neste trabalho não se fechou a análise no conceito de ator, restringindo o foco nos magistrados, pois se considerou na observação empírica, outros elementos importantes da investigação. Segundo Vanhamme e Beyens (2007), é importante reconhecer como os juízes contemporâneos estáo inseridos em um contexto que eles dialogam e interagem com vários inputs externos (opinião pública, caracterização de vítimas e agressores, reflexividade do próprio sistema penal etc) e, nesse sentido, podem sofrer impactos em suas trajetórias e suas institucionalidades. $\mathrm{O}$ investimento maior é compreender a própria dinâmica dos aspectos penais da vara da infância e juventude, no tocante a sua acepção de uma organização reflexiva, que constrói realidades próprias, na medida em que configuram determinados sentidos as suas açôes sociais. $\mathrm{O}$ ator social aqui caracterizado pela figura do magistrado não é o único sistema a produzir sentido, mas ele representa institucionalidade que oferece informaçóes sobre a prática penal, ou como Raupp (2015) sinaliza - revela potencialidades para descobrir como o Direito Penal se constrói e opera.

Nesse enredo, as varas de infância e juventude buscam protagonizar a excepcionalidade da disposição das sançóes, sem as penalidades, tendo em vista que seu caráter inimputável as pessoas com menos de 18 anos de idade. $\mathrm{O}$ ato infracional que regula o princípio jurídico do ECA, a Lei que regula essas varas, assume um estado de equiparaçáo à conduta descrita como crime ou contravençáo penal, mas não dinamiza os seus efeitos penais sobre a regra legal, considerando que seus dispositivos têm características distintas na aplicação das sançóes. $\mathrm{O}$ ato infracional só tem existência, tal como o crime, diante do nexo de causalidade entre a conduta e o resultado danoso.

Entretanto, é importante sinalizar que não há consenso na doutrina sobre a natureza jurídica da medida socioeducativa, conforme revela Liberati:

De um lado, há os que sustentam que a medida socioeducativa é despida do caráter sancionatório, e, por assim dizer, punitivo. De outro, os que afirmam que as medidas socioeducativas comportam aspectos de natureza coercitiva, vez que são punitivas aos infratores, e aspectos educativos no sentido da proteção integral e oportunizar o acesso à formação e informação, sendo que, em cada medida, esses elementos apresentam graduação, de acordo com a gravidade do delito cometido e/ou sua reiteraçáo (LIBERATI, 2006, p. 141). 
Essa condição configura elementos mais subjetivos na aplicação das sançóes, pois o ECA apesar de dimensionar os aspectos penais na responsabilização do dano, estabelece o critério de individualização das medidas socioeducativas nos parâmetros de fixação e execução da sanção infracional, que difere do critério trifásico ${ }^{6}$ adotado pelo Código Penal. Essa configuração amplia a discricionariedade dos juízes, considerando que não há uma legislação específica que oriente e estabeleça diretrizes que regulem com maior rigor a execução das medidas socioeducativas, sobretudo na aplicação de medidas de privação de liberdade. Os elementos que consubstanciam essas aplicações e execuções determinadas nas sentenças são dispositivos gerais de princípios, que destacam a excepcionalidade da capacidade da criança e do adolescente na execução da medida socioeducativa; as circunstâncias e a gravidade da infração. Os princípios, também, configuram orientaçóes globais, generalizadas na doutrina, retratadas por três princípios básicos: princípio da excepcionalidade, descrito acima; no princípio da brevidade e no princípio do respeito à condição peculiar de pessoa em desenvolvimento.

O princípio da excepcionalidade incide diretamente na fase de imposição pelo Poder Judiciário da medida mais adequada ao caso concreto, levando em conta as circunstâncias e a gravidade do ato praticado, e as condiçóes de cumprimento da medida por parte do adolescente, como prescreve o art. $112, \$ 1^{\circ}$. [...] A brevidade impóe a menor duração possível para privação da liberdade, de modo que sua vigência se dê estritamente no limite da necessidade. Por fim, o respeito à condiçấo peculiar de pessoa em desenvolvimento relaciona-se à necessária individualização da medida em atenção às características pessoais do jovem e, como já mencionado, a sua capacidade de cumprir a determinação judicial, de tal forma que o cumprimento da internação atenda às exigências de acompanhamento personalizado (SPOSATO, 2006, p. 128).

${ }_{6}$ É um método para realizar o cálculo da pena, dividido em três fases: primeiro o juiz busca sempre menor pena de um crime, caracterizada como pena-base; na segunda fase, analisam-se as circunstâncias agravantes e, por fim, a análise das causas de aumento e diminuição das penas. 
Nas práticas adjudicantes, essas configuraçóes revelam disposiçōes fluídas, considerando a acepção da natureza jurídica da medida socioeducativa. Ainda como Liberati (2006) demonstra:

O sistema de resposta estatal à prática de ato infracional, adotado pela Lei n. 8.069/1990, considera, primordialmente, a pessoa que o praticou, não estabelecendo vínculo desta ou daquela medida ao tipo penal praticado. Tal critério será de livre escolha do julgador, que fixará a medida socioeducativa mais adequada à socialização do infrator (LIBERATI, 2006, p. 143, grifo da autora).

É bom lembrar, contudo, que a constituição de um novo modelo de relação entre justiça e criança e adolescente só foi possível ser estabelecido a partir da implantaçáo do Estatuto da Criança e do Adolescente - ECA. Este nasce no bojo de um processo de transiçáo política para democratizaçâo do país, logo após a criação da nova Constituição Federal de 1988, instrumentalizado pelos movimentos sociais, que reivindicavam o declínio do Código de Menores/1979 e exigiam uma proteção especial para o universo infantojuvenil. Esse ordenamento conclamou diferentes instituiçôes sociais à proteçâo desse grupo social: família, Estado e sociedade civil, bem como previu a formalização de políticas para garantia dos direitos impetrados pelo Estatuto. É bom lembrar, contudo, que a tradição brasileira de atenção às crianças e aos adolescentes estabeleceu-se, historicamente, por açóes vinculadas às práticas de controle social, e não focalizando diretamente a promoçáo de seus direitos. As iniciativas nesta área, no Brasil, foram marcadas, por um lado, pela lógica de prevenção e de combate ao crime através da educação pelo trabalho e, por outro lado, por empreendimentos de cunho caritativo, voltados às crianças e adolescentes desvalidos. É importante demarcar essa percepção da infância pelos estatutos legais, pois revelam a caracterização de um tipo específico de atenção a esse grupo por parte dos tribunais, durante um contexto histórico, bem como suas mudanças (ARANTES, 1990). O ECA definiu uma compreensão da criança e do adolescente como pessoa em condição de desenvolvimento e sujeito de direitos fundamentais, mas os tribunais carregam tradiçóes conservadoras ainda com resquícios inventariados pelo Código de Menores, bem como ainda é elemento de percepção controversa de parte da sociedade. 
O ECA/1990, por seu caráter holístico, não tem o perfil acusatório do ordenamento penal, característico dos códigos penais, contudo, regula práticas delituosas contra crianças e adolescentes. Os quase trinta atos proibitivos estão previstos em treze artigos (do Art. 245 ao Art. 258). Além de outras providências, estabelece regulaçóes, no que tange à política de atendimento, criando arranjos institucionais de resoluçáo de conflitos e órgãos permanentes e autônomos, não jurisdicionais, voltados à fiscalização do cumprimento dos direitos da criança e do adolescente, como são os Conselhos Tutelares. Essas instâncias formais de resolução de conflitos representam grande parte dos conflitos, envolvendo crianças e adolescentes e funcionam como instâncias seletivas dos litígios que chegam aos tribunais. Em razão máxima da integraçáo do sistema de garantia de direitos composto por instituiçóes alocadas na sociedade civil e do Estado, variados agentes ${ }^{7}$ institucionais caracterizam a rede de proteção, com função de responsabilização, elaboração de políticas e fiscalização, e no âmbito da prevençáo e assistência.

A reflexão nesse sentido deve levar alguns aspectos teóricos em consideração. A ideia assentada numa proteção integral de crianças e adolescentes no ECA náo deixa de ser também uma forma de se projetar uma unidade nacional com relaçáo a esse grupo social, escamoteando as diferenças políticas, econômicas, sociais e culturais que balizam os interesses dessa proteção. A compreensão de uma referência modernizadora que compóe mecanismos políticos e efeitos de discurso se revela pelos dispositivos na acepção de Foucault (1979, p. 244), ou seja:

[...] um conjunto decididamente heterogêneo que engloba discursos, instituiçôes, organizaçôes arquitetônicas, decisôes regulamentares, leis, medidas administrativas, enunciados científicos, proposiçôes filosóficas, morais, filantrópicas.

\footnotetext{
Essas instituiçôes são consideradas apenas como porta de entrada das ocorrências, não compóem o fluxo jurídico. Elas não são uniformes na cobertura nacional, em razão da autonomia político-administrativa dos estados e municípios na instalação desses serviços, mas funcionam como mediadores nos casos de maus-tratos infantojuvenis. Além da estrutura representativa do Estado, que se configura na sua dimensão jurídica, tem sua ação fiscalizadora fragilizada por essa perspectiva, na medida em que ainda não consegue integrar efetivamente as forças políticas no processo de gestão das políticas públicas na garantia dos direitos de crianças e adolescentes (MARTINS, 2007).
} 
Esses dispositivos revelam as práticas discursivas que estão estabelecidas como instituiçóes a partir dos efeitos que elas produzem, caracterizando relaçóes de poder, produção de saberes, jogos de palavras compostos de nuances implicadoras no processo de dominação. Essa unidade substancializadora é extremamente complexa do ponto de vista de sua constituição integral no sistema cultural. Os ajustes e adaptaçóes são procedimentos comuns apropriados pelos tribunais (no caso particular dessa análise) que divergem dessa ilustração política doadora de direitos. Nosso legado autoritário e conservador da cultura política nacional se estabeleceu sobre a amálgama da inovação e da tradição. Logo, essas transformações progressistas não são simples e rápidas, e, por vezes, resistem em se estabelecer. Portanto, os enquadramentos dessas normatizaçóes nos Códigos Penais, inclusive no dito Direito Penal Infantojuvenil, têm seus limites formais-materiais e, sobretudo, políticos.

Um outro ponto importante neste trabalho busca atender a apresentação de um panorama do perfil dos magistrados da justiça da juventude, revelando as características de gênero que buscarão os graus de feminização e masculinização (MOREL; PESSANHA, 2007) desses magistrados, no que tange as percepçóes deles sobre uma suposta heterogeneidade ideológica na composição da administração da justiça.

\section{As Varas da Infância e Juventude}

Os resultados apresentados revelam o perfil das Varas da Infância e Juventude da Bahia e de Minas Gerais. Os mesmos aduzem a uma compreensáo dos processos instaurados na caracterização do perfil dos magistrados, na questão do gênero, particularmente.

É interessante ressaltar que a composição desses magistrados se refere à justiça estadual de primeiro grau, nos estados de Minas Gerais e da Bahia, para as Varas da Infância e Juventude. Vale frisar que, mesmo no interior dessa vara, há uma diferenciação com relação à matéria dos julgamentos. Ela pode se situar na seção cívil, caracterizando processos de conhecimento; como também na seção infracional, conferindo processos de apuraçáo de atos infracionais.

No Brasil, o Poder Judiciário está estruturado com 15.773 unidades judiciárias de primeiro grau, sendo 14.175 varas estaduais, do trabalho e federais, 1.598 juizados especiais, 3.039 zonas eleitorais, 13 auditorias 
militares estaduais e 19 auditorias, segundo dados do Conselho Nacional de Justiça, apresentados pelo 12 relatório Justiça em Números $-2016^{8}$.

Para efeito desse texto, vale salientar também que a estrutura da justiça estadual de primeiro grau é caracterizada por 2.710 comarcas para atender os 5.570 municípios brasileiros. Isso revela que nem todos os municípios têm a cobertura de uma comarca judiciária. No Brasil, apenas $49 \%$ dos municípios são sede de comarca. Isso implica revelar que as comarcas, normalmente, têm competências diversas, aglutinando especialidades. Isso não é uma prerrogativa dos estados de $\mathrm{MG}$ e da $\mathrm{BA}$, mas uma característica do poder judiciário brasileiro. Inclusive que regula disposiçôes para instalação de varas, de qualquer especialidade, curiosamente no âmbito de outro Poder. A criação das varas ocorre a partir da aprovação de um projeto de lei, no âmbito do Poder Legislativo, nas Assembleias Legislativas nos Estados, cabendo ao Judiciário instalá-las.

A justiça estadual no Brasil possui 5,4 magistrados por 100.000 habitantes. Contudo, tem uma demanda processual bem excessiva se comparada a outros países. Esse quantitativo parece revelar um paradoxo na justiça brasileira, porque revela como esses magistrados são considerados um dos mais produtivos ${ }^{9}$, mas possui uma justiça morosa e assoberbada. Comparado aos países europeus não revela uma justiça rápida e ágil nos trâmites processuais. Segundo dados do Conselho Nacional de Justiça/2016, países como Portugal, Itália e Espanha têm demandas muito inferiores às demandas no Brasil. No Brasil, são cerca de 1.616 sentenças por ano, em detrimento de 959/ano na Itália; 689/ano sentenças na Espanha e 397/ano em Portugal. Por sua vez, a comparação está aliada ao número de magistrados por 100.000 habitantes. O Brasil seria 5,4 magistrados/100.000 habitantes, 19 magistrados/100.000 em Portugal; 10,7 magistrados/100.000 na Espanha e 10,2 magistrados/100.000 na Itália.

Este quadro revela o quanto é complexa a situação do Poder Judiciário no Brasil. Observa-se uma demanda bastante significativa de reclames processuais, em detrimento da oferta de recursos humanos. Essa dispo-

8 Justiça em Números é um relatório realizado pelo Conselho Nacional de Justiça e Ministério da Justiça, com dados exclusivos dos Tribunais que integram o Sistema de Estatística do Poder Judiciário - SIESPJ, conforme o Art. $4^{\circ}$ da Resoluçáo CNJ 76/2009. Os dados que foram utilizados para esta pesquisa tratam do ano base 2015.

9 Em termos de resolução dos conflitos. 
sição do judiciário nacional tem inferências analíticas diversas, como: o contexto excessivo de açóes repetitivas com serviços públicos diretos concedidos pelo Governo e que poderia ser resolvido no âmbito das agências reguladoras e administração pública; demandas por execuçóes fiscais por processos de cobrança de dívida da administração do Governo; eficiência produtiva não quer dizer uma justiça distributiva, necessariamente. A impressão que se tem é que a mobilização que o $\mathrm{CNJ}$ tem realizado perante os tribunais tem causado um efeito deformador, uma vez que muitos casos são arquivados sob a pressáo para a resolução dos conflitos ainda na fase inicial das ações judiciais.

\section{Minas Gerais e Bahia - perfil da cultura judiciária}

O Tribunal de Justiça do estado de Minas Gerais - TJMG está classificado como o primeiro Estado brasileiro em termos de número de comarcas. São 296 instaladas e mais 17 não instaladas, mas já com aprovação nas Assembleias. Isso elevaria a um número de 313 comarcas.

Segundo dados do CNJ, o TJMG está classificado ${ }^{10}$ como um tribunal de grande porte, essa classificação reúne os tribunais de São Paulo, Minas Gerais, Rio de Janeiro, Rio Grande do Sul e Paraná. São Paulo é considerado o Tribunal de Justiça de maior porte, em razão do número de varas e juizados - o quantitativo de 1.929, em detrimento dos 852 varas e juizados de Minas Gerais. Contudo, em termos de número de comarcas, MG supera SP com 296 comarcas, em detrimento de 273 comarcas paulistas.

A Bahia, no tocante a 417 municípios, apesar de ter um número expressivo de comarcas, diante dos estados classificados de grande porte, é considerado um tribunal de médio porte, explicado pela metodologia

${ }^{10}$ O CNJ, através do Justiça em Número/2016 - ano base 2015, realizou um relatório a partir de uma classificação baseada em três agrupamentos: grande, médio e menor porte. Considerando a diversidade entre as realidades brasileiras, e consequentemente dos tribunais de justiça brasileiro para produção de análises equânimes e proporcionais, foi desenvolvida uma metodologia a partir de comparaçóes cujos dados postulassem familiaridade entre si, com as variáveis: despesa total, processos que tramitaram no período, número de magistrados, número de servidores e trabalhadores auxiliares. 
que regulou o estudo. Foram identificadas 236 comarcas e 904 varas e juizados. Isso daria cerca de $54 \%$ de cobertura de unidades judiciárias. O estado de Minas Gerais com seus 853 municípios tem um percentual de $34,7 \%$ de cobertura de unidades judiciárias de primeiro grau, em seus municípios. Numa visão mais ingênua, poderia parecer que a Bahia estaria com maior oferta de uma prestação jurisdicional, contudo, quando se observa outros dados, como despesa total, processos que tramitaram no período, número de magistrados, número de servidores e trabalhadores auxiliares, segundo a Justiça em Número/2016, a Bahia é classificada como um tribunal de médio porte.

No Brasil, esse percentual sobe para $64,4 \%$ de cobertura, mas isso não quer dizer que a distribuição seja equitativa no território brasileiro.

A referência do quantitativo populacional é importante para a administração judiciária no que tange a definição de competências exclusivas. Segundo o IBGE, atualmente, 298 municípios brasileiros possuem mais de 100.000 habitantes. A distribuição se estabelece em razão da demanda populacional e, dessa forma, a distribuição não é equilibrada. Diante desses dados se observa que no Brasil, não há critérios claros e formais para a implementação de varas exclusivas de infância e juventude. A única referência normativa é apresentada na Resolução n. 113, do Conselho Nacional dos Direitos da Criança e do Adolescente - CONANDA, que estabelece que:

[...] o Poder Judiciário, o Ministério Público, as Defensorias Públicas e a Segurança Pública deverão ser instados no sentido da exclusividade, especialização e regionalização dos seus órgãos e de suas açôes, garantindo a criação, implementação e fortalecimento de:

I Varas da Infância e da Juventude, específicas, em todas as comarcas que correspondam a municípios de grande e médio porte $^{11}$ ou outra proporcionalidade por número de habitantes, dotando-as de infraestruturas e prevendo para elas regime de plantáo;

${ }^{11}$ De acordo com o IBGE, municípios de médio porte são aqueles entre 50.001 a 100.000 habitantes e de grande porte aqueles com população entre 100.001 a 900.000 habitantes. 
II Equipes Interprofissionais, vinculadas a essas Varas e mantidas com recursos do Poder Judiciário, nos termos do Estatuto citado.

Essa é uma regra esquecida que reclama uma obrigatoriedade de estabelecimento jurisdicional entre varas especializadas e população. Segundo os dados do Relatório da ABMP/2008, os estados com maior densidade populacional em que se observam as maiores complexidades de problemas, por incrível que pareça, apresentam os piores critérios populacionais para a criação das varas especializadas dessa matéria.

Contudo, essa cobertura não se caracteriza, ainda, como uma regra absoluta e exata, a partir de um dos critérios regentes, como o município possuir uma população com mais de 100.000 habitantes.

No estado de Minas Gerais, por exemplo, muitos municípios possuem o critério de 100.000 habitantes para criação das varas, assim mesmo, não estão cobertos com varas especializadas. Segundo o IBGE/2010, são trinta e dois municípios com população superior a 100.000 habitantes e apenas quatro ${ }^{12}$ com competência exclusiva para julgamento de matéria da infância e juventude. Um percentual em torno de $12,5 \%$ se considerarmos as possibilidades de competência exclusiva.

Em termos comparativos, a Bahia se destaca com um percentual de $56,5 \%$ em termos de cobertura de unidades judiciárias de primeiro grau em seus 417 municípios. A oferta da cobertura de varas de competência exclusiva na matéria de infância e juventude também foi identificada uma superação em comparaçáo com MG, uma vez que o percentual foi de $76,5 \%{ }^{13}$. Segundo a lista do IBGE/2010, foram identificados $15 \mathrm{mu}$ nicípios com população superior a 100.000 habitantes, e somente três municípios não foram contemplados com varas de competência exclusiva.

No caso de nosso foco de estudo, em MG, na Zona da Mata mineira é um exemplo dessa situação. Ubá com 11.012 habitantes não possui vara de competência exclusiva para a infância e juventude; bem como $\mathrm{Mu}$ riaé, com 107.263 habitantes, sem contar o restante dos trinta municípios descobertos por esse princípio populacional. Vale registrar que ambas as

12 Juiz de Fora, Contagem, Uberaba e Uberlândia. Lista retirada direto do site do TJMG, atualizada em 16/11/2016. Aqui náo se contabilizou o efetivo da capital, uma vez que não foi citado no referido documento.

13 Não foram contabilizadas aqui também as varas da capital. 
comarcas se caracterizam por varas aglutinadas, com competências diversificadas concorrentes.

Segundo dados do CNJ somente $12 \%$ de varas da infância e juventude, na justiça estadual no Brasil, são de competência exclusiva dessa matéria, ou seja, de um universo de 1.303 varas de infância e juventude, apenas 159 são de competência exclusiva.

Contudo, essas comparaçóes entre Bahia e Minas Gerais sofrem relativizaçóes quando observadas, por exemplo, a composição da oferta de equipes técnicas que assessoram o magistrado no julgamento da matéria. Minas Gerais tem uma diversificação de profissionais interdisciplinares maior que na Bahia, em suas comarcas.

\section{A masculinização da magistratura regional}

Segundo os dados da pesquisa realizada pelo Conselho Nacional de Justiça - CNJ/2013, a magistratura brasileira é composta majoritariamente por homens, onde cerca de $64 \%$ dos magistrados são do sexo masculino. Eles chegam a representar $82 \%$ dos ministros dos tribunais superiores. Os dados da pesquisa nas comarcas da Zona da Mata, em MG e na BA seguiram essa tendência nacional, com baixa representaçáo feminina.

Essa tendência não é um fator uníssono em todos os ramos do Judiciário, como revelaram Morel e Pessanha (2007). Os dados comparativos entre o perfil dos magistrados da Justiça do Trabalho e demais ramos revelam o fenômeno da feminizaçáo desse ramo do judiciário para o universo Brasil. O que náo foi correspondido no tocante a essa região de MG para as varas da Infância e Juventude nem na Bahia. Vale registrar que na Bahia esse dado é representativo em termos de proporção numérica. Considerando que os percentuais entre homens e mulheres na Bahia são muito próximos.

Em todo o estado de MG, com suas 296 comarcas em 2016, conferida e atualizada em 16/11/2016 há um percentual de 30\% de magistradas. Essa composição, também, foi observada nas magistraturas da Zona da Mata mineira, para as Varas de Infância e Juventude, com o percentual de $28,6 \%$ de magistradas.

Curiosamente, para compreender essa situação na realidade mineira, foram buscados dados mais anteriores, para procurar entender a representação desse percentual. Na mesma fonte, com dados de 2012, foi analisada 
também essa cobertura de gênero na magistratura, ao que, curiosamente, o percentual foi levemente superior ao ano de 2016. Isso revela que não houve uma progressão significativa, pelo contrário, houve um decréscimo, considerando que o percentual de 2012 foi de 32\% de magistradas.

$\mathrm{Na}$ Bahia, no universo de 17 varas de competência exclusiva de material da infância e juventude foram identificadas oito magistradas, em comparaçáo com nove magistrados, o que em termos substanciais podemos considerar um equilíbrio.

Melo et al. (2005) declaram que:

À pouca representatividade de mulheres em espaços de poder e decisão chamados de fenômeno de masculinização do comando e feminilização da subalternidade. Esse fenômeno demonstra que, mesmo frente aos espaços conquistados pelas mulheres na sociedade, o poder de mando permanece fiel a lógica da cultura patriarcal. No judiciário, poder que espelha essa cultura, a participaçáo de mulheres e homens também acontecem de forma desigual.

Entretanto, o mesmo autor considera que o crescimento de mulheres na magistratura vem crescendo progressivamente da década de 1980 a 2010. No mesmo estudo, ele apresenta uma projeção da participação das mulheres na magistratura até 2020 e reitera essa configuração de distribuiçóes relativas à demografia do Poder no Brasil.

Bonelli (2013), também, reforça essa identificação da sub-representação do feminino nas carreiras da magistratura no Brasil. A autora chama a atenção para diferentes formas de desigualdade de gênero no mundo jurídico, como a questão da compatibilização das frequentes mudanças de cidades que favorecem a obtenção de promoçáo profissional e a responsabilidade com a unidade familiar - cônjuge e filhos; uma maior autonomia em relação a intervençóes externas e a consolidação dos elementos que definem o modelo de profissionalismo na carreira judiciária antes do ingresso da mulher, que teria produzido um "fechamento generificado" etc.

Um dado interessante que a autora apresenta diz respeito, inclusive, às avaliaçóes consideradas positivas, como as caracterizadas pela representação simbólica de magistradas serem "mais compreensivas e mais diligentes”. Bonelli (2013) destaca de o risco dessas representaçóes capitalizar o que é diferente e essencializar na condição feminina aquilo que deve ser superado para tal condição, ou melhor, ser admitido em ambas condiçóes. 
Essa talvez seja uma das formas, dentre outras, camufladas de observar as desigualdades de gênero na magistratura.

\section{Os impactos das competências jurisdicionais concorrentes e a masculinizaçáo da justiça}

A apresentação desses dados revela algumas pistas já manifestas na literatura, como o comprometimento da qualidade da prestação jurisdicional para os fenômenos de competências concorrenciais e a masculinização da magistratura.

No tocante à questão das competências concorrentes, é notório o quanto a disposição das varas da infância e juventude em todo o Brasil se mostra com essa característica, ou seja, as varas de matéria da infância e juventude se apresentam de forma significativa na forma aglutinada com outras especialidades, e em alguns locais, de forma mais gritante aliadas a varas criminais.

Essa situação tem implicações severas, considerando as possibilidades razoáveis de contaminação do padrão de pensamento do magistrado; bem como de todo corpo operacional que o sustenta, na sua maioria com a inobservância de uma equipe técnica interdisciplinar. Conforme sinaliza a sentencing com Vanhamme e Beyens (2007), fatores externos podem influenciar o processo de decisáo judicial, como a reflexividade do próprio sistema penal, que imprime institucionalidades nas práticas jurídicas, de modo a impactar as trajetórias de desempenho do magistrado.

A determinação dessa reflexividade do sistema penal constrói realidades próprias, diante do emaranhado de práticas existentes no tocante aos juízos aglutinados, determinando outros sentidos às açôes sociais desenvolvidas nesses ofícios jurídicos. Um exemplo dessa operação com atribuiçôes de sentidos severos no âmbito da vara da infância e juventude diz respeito aos conflitos ligados ao universo escolar, judicializando os conflitos existentes nesses espaços, capitalizando toda a operação comunicativa existente nesse ambiente para um arcabouço jurídico penal, ainda que se esteja falando em infraçóes penais. Essa configuração opera nas potencialidades subsumida do Direito Penal, impresso nos artigos das penalidades do ECA, que pode colocar esses grupos sociais - crianças e adolescentes de frente para um universo já austero, de forma bastante precoce, muitas das vezes, de forma desnecessária. 
Considerando, sobretudo, o universo de distorçôes que envolvem a administração dos tribunais com relação a uma oferta da prestação jurisdicional de forma virtuosa no ponto de vista operacional, com apoio e assessoramento dos magistrados, com equipe técnica interdisciplinar e sua distribuição especial frente às demandas, já se observa o quilate de problematizaçôes que açóes dessa natureza podem promover. Também se sabe o quanto a vulnerabilidade de crianças e de adolescentes ameaça a doutrina da proteção integral, considerando os fatores multidimensionais que envolvem julgamentos desse mote e, por isso, exigem uma qualificação primordial da composição das normativas que a regulam; mas, muito mais que isso, exige-se uma aproximaçáo com essa realidade e essa especificidade, com absoluta perícia e foco das atençóes nesse conjunto de disposiçóes que envolvem diferentes trajetórias e conflitos sociais desse grupo social.

A realidade social não é harmoniosa, linear e progressiva. Ela é articulada e conformada, significativamente por diferentes dialéticas e, dessa forma, a vontade coletiva de um corpo de magistrados reverbera a produção de um sentido de ordem. Um sentido de ordem voltado para práticas normativas-legalista, como é comum em tribunais de variadas especialidades tende a operar com significaçóes arbitrárias do contexto social. Porque como atua numa percepção mais genérica, fora de foco, com vocábulos de motivos pretensamente científicos, revelam ações jurídicas não factíveis, plasmando-se em discursos reificantes, a-históricos e com pretensóes universalistas. Libera-se de uma apresentaçáo jurídica a partir de institutos que realmente incidam em resoluçóes de conflitos, com raízes nos contextos sociais, valorizando uma abordagem sistemática e, no limite priorizando o princípio da autoridade, com vocábulos de motivos, muitas vezes de tom moralizador.

Em contextos de extrema desigualdade social como o Brasil, o risco dessa ordem toma grandeza, pois não é possível que os tribunais se orientem a tratar cada problema de forma isolada, sob o risco de dispersáo e fragmentação das funçóes regulatórias do Estado. Contudo, as necessidades de ordem prática que operam esses litígios têm cobrado dos magistrados, principalmente das varas da infância e juventude, novos graus de especialização funcional e técnica em sua formação profissional e, inclusive, extrajurídicos como sinaliza Faria (1989).

No rastro dessa reflexão, a dinâmica que revela o quanto o quadro profissional das carreiras jurídicas aduz a essa dinâmica unilateral, corporativa também reage a um processo de homogeneizaçáo de toda 
natureza, seja de corte de gênero e de raça/cor ou qualquer outra especificação. A heterogeneidade da ordem social da corporação deve favorecer pluralidades de orientaçóes, marcadamente para estabelecer um rompimento com uma tradição normativa.

Segundo Bonelli (2010), a diferença sexual e de gênero não determina identidade profissional, mas sim a experiência, a vivência da magistratura no ambiente jurídico especializado. Não são sexualidade e gênero que determinam essas vivências. Contudo, nenhuma experiência pode ser absoluta, plena sem a cobertura plural de representaçóes das condiçóes do feminino ou do masculino, sobretudo em contextos tão complexos como conflitos dessa natureza. A heterogeneidade de representaçóes compóe o substrato que legitima as açóes no plano do planejamento e implementação das açôes sociais manifestas nesses juízos. É sabido que a heterogeneidade ideológica dos magistrados não resulta de uma forma automática, da existência de uma heterogeneidade social. Mas ela alimenta produção de sentidos e reverbera institucionalidades próprias que condicionam a magistratura no processo de construção de vocábulos de motivos na sua exposição. Foi resgatando Vanhamme e Beyens (2007) que destacam a importância de reconhecer como os juízes contemporâneos estáo inseridos em um contexto que eles dialogam e interagem com vários inputs externos (opinião pública, caracterizaçấo de vítimas e agressores, reflexividade do próprio sistema penal etc) e, nesse sentido, podem sofrer impactos em suas trajetórias e suas institucionalidades.

A questão da masculinização da magistratura também toca na questão da democratização do próprio tribunal, onde o mundo jurídico ainda se revela com ares corporativos na conjectura de gênero, revelando um descompasso entre uma igualdade jurídica e desigualdade social. Vianna et al. (1997) destacaram as tendências existentes entre o perfil da magistratura e a democratização da prática adjudicante e do próprio Poder Judiciário, relacionando com os elementos da cultura jurídica.

No cômputo final do trabalho, o que se destaca são implicaçóes dessa natureza como o fenômeno da masculinização da magistratura e a composição de varas da infância e juventude concorrentes com outras especialidades que favorecem a potencialização, a discricionariedade dos magistrados dessa matéria, uma vez que não há uma legislação específica que regule a orientação da aplicação das medidas socioeducativas. As diretrizes mais genéricas expressas no ECA não são suficientes para dispor um controle na discricionariedade dos magistrados e condicionam as açóes 
desse juízo a disposição da qualidade formativa desse magistrado. Logo, a complexidade que circunda o universo de conflitos que envolvem crianças e adolescentes no Brasil exige mais... muito mais, sobretudo em contexto de franco avanço do fenômeno da judicializaçáo de conflitos.

\section{Referências}

ARANTES, E. M. M; MOTTA, M. E. S. A Criança e Seus Direitos: Estatuto da Criança e do Adolescente e Código de Menores em Debate. Rio de Janeiro, PUC/ RJ - FUNABEM, 1990.

BARBALHO, Rennê Martins. A feminizaçáo das carreiras jurídicas e seus reflexos no profissionalismo. Tese (Doutorado) - Programa de Pós-Graduação em Sociologia, UFSCar, São Carlos, 2008.

BONELLI, Maria da Gloria. Profissionalismo, gênero e diferença nas carreiras jurídicas. São Paulo: Editora EDUFscar, 2013.

. Profissionalismo e diferenças de gênero na magistratura paulista. Revista Civitas: Porto Alegre, v. 10, n. 2, p. 270-292 /mai./ago., 2010.

BRASIL. Lei no 8.069, de 13 de julho de 1990.

Associação Brasileira de Magistrados, Promotores de Justiça e Defensores Públicos da Infância e da Juventude - ABMP. O sistema de justiça da infância e juventude nos 18 anos do estatuto da Criança e do Adolescente - desafios da especializaçáa. 2008. Disponível em: <http://www.ufrgs.br/napead/repositorio/ objetos/estacaopsi/anexos/Desafios_Sistema_Justica.pdf> Acesso em: 4 dez. 2016.

. Justiça em números 2016: ano-base 2015/Conselho Nacional de Justiça - Brasília: CNJ, 2016.

EMYGDIO, Romeu Ferreira. Uma análise da ocupaçáo de Juízes por gênero, raça e cor no Brasil e por Unidade da Federaçáo. Trabalho apresentado no XVIII Encontro Nacional de Estudos Populacionais, ABEP, realizado em Águas de Lindóia/SP - Brasil, de 19 a 23 de novembro de 2012.

FARIA, José Eduardo. Direito e Justiça: a função social do judiciário. São Paulo: Editora Ática, 1989.

FOUCAULT, Michel. Microfísica do poder. Rio de Janeiro: Graal, 1979. 
HIRATA, Helena; KERGOAT, Danièle. A divisão sexual do trabalho revisitada. In: Maruani, Margareth; Hirata, Helena (Orgs.). As novas fronteiras da desigualdade: homens e mulheres no mercado de trabalho. São Paulo: Senac, 2003.

IBGE Disponível em: <http://censo2010.ibge.gov.br> Acesso em: 1 dez. 2016.

MARTINS. Rogéria. Abuso sexual e a escola: o público e o privado na "gestão democrática" das políticas públicas. Dissertação (Mestrado). Salvador: Universidade Federal da Bahia, 2007.

Estupro de crianças e adolescentes e a desigualdade dos tribunais uma análise de processos judiciais. Saarbrückken, Editora Novas Ediçóes Acadêmicas, 2013.

LIBERATI, Wilson Donizeti. Processo Penal Juvenil: a garantia da legalidade na execução de medida socioeducativa. São Paulo: Malheiros, 2006.

MELO, Mônica et al. A participação da mulher na magistratura brasileira. 2005. Disponível em: < http://www.spm.gov.br/assuntos/poder-eparticipacaopolitica/referencias/genero-e-poder-judiciario/a_participacao_da_ mulher_na.pdf >. Acesso em: 1 dez. 2016.

MOREL, Regina Lúcia; PESSANHA, Elina G. da Fonte. A justiça do trabalho. Revista Tempo Social, v. 19, n. 2, p. 87-109, 2007.

RAUPP, Mariana. As pesquisas sobre o sentencing: disparidade, punição e vocabularies de motivos. Revista de Estudos Empirícos em Direito, v. 2, n. 2, p. 174-191, jan., 2015.

SPOSATO, Karyna Batista. O Direito Penal Juvenil. São Paulo: Revista dos Tribunais, 2006.

THOMSON, R. J. E ZINGRAFF, M. T. Detecting sentencing disparity: some problems and evidence. American Jounarl of Sociology, v. 86, n. 4, p. 869-880, 1981.

VANHAMME, F. e BEYENS, K. La recherche em sentencing: um survol contextualisé. Deviance et Societé, 31: 199 - 228, 2007.

VIANNA et al. Corpo e alma da magistratura brasileira. 3. ed. Rio de Janeiro: Revan, 1997. 


\title{
O LIMPADOR DE PARA-BRISA E A CRIAÇÃO DO SEU DIREITO À CIDADE
}

\author{
Patrícia Jerônimo Sobrinho ${ }^{1}$ \\ Idemburgo Pereira Frazão ${ }^{2}$ \\ Jurema Rosa Lopes ${ }^{3}$
}

\section{Introdução}

Basta simplesmente transitar pela cidade do Rio de Janeiro para deparar-se com pessoas coletando resíduos, vendendo doces nas esquinas ou mendigando em espaços públicos, dentre outras questóes. Esses antigos e novos ofícios, geralmente, relacionados com os menos favorecidos convidam à reflexão sobre os entraves de uma sociedade desigual que coloca à vista de todos, na rua, um trabalho inserido às margens da informalidade.

Em um contexto em que os "bicos" se apresentam como uma única prática de subsistência possível, este artigo se detém em um segmento específico de trabalho, considerado tipicamente estigmatizado e que está inserido em ambientes sociais dominados pelo espaço urbano contemporâneo. Trata-se de sujeitos que oferecem seus serviços nas esquinas da cidade do Rio de Janeiro, em troca de uma colaboração à vontade do motorista.

As consideraçôes feitas aqui são frutos da observação desse grupo pelas esquinas e semáforos do Rio de Janeiro. Nesses espaços, percebe-se que há uma mistura entre a necessidade, a informalidade do trabalho, a

1 Doutoranda do Programa de Pós-Graduação em Humanidades, Culturas e Artes/Universidade do Grande Rio (Unigranrio), Duque de Caxias - Rio de Janeiro, Brasil; docente do Centro Universitário Augusto Motta (UNISUAM), Rio de Janeiro, Brasil; professora da Secretaria de Estado de Educação do Rio de Janeiro, Brasil. E-mail: <professoremacao@gmail.com>.

2 Docente do Programa de Pós-Graduação em Humanidades, Culturas e Artes da Universidade do Grande Rio (Unigranrio), Duque de Caxias, Rio de Janeiro, Brasil. E-mail: <idfrazao@uol.com.br>.

3 Docente do Programa de Pós-Graduação em Humanidades, Culturas e Artes e do Programa de Pós-Graduação em Ensino das Ciências da Universidade do Grande Rio (Unigranrio), Duque de Caxias, Rio de Janeiro, Brasil.E-mail: <jlopes@unigranrio.edu.br>. 
criatividade, que compóem este fenômeno, cuja determinação subjaz uma problemática de exclusão e discriminação social.

Estudar a atividade desse grupo permite entender a constituição de uma prática de trabalho organizada por uma "população excluída" frente à situação socioeconômica atual. Através dela, seus integrantes se encarregam de fazer uma efetiva ocupação de semáforos e esquinas, ou seja, tomam controle dos espaços públicos como uma forma de "ganhar a vida". Uma população que ocupa as ruas da cidade - subsistindo graças a sua mobilidade - e que sempre está "à margem” da sociedade, mas que cria o seu próprio direito à cidade.

Este artigo está organizado do seguinte modo: na primeira seção destacam-se alguns apontamentos sobre globalização; na segunda discorre-se sobre os usos do espaço público, da esquina e do semáforo como locais de trabalho; na terceira seção descreve-se a atividade dos limpadores de para-brisas; na quarta efetuam-se alguns comentários sobre o limpador de para-brisa e a criação do seu direito à cidade. Por último, tecem-se algumas consideraçóes finais.

\section{A Globalizaçáo e o "Lixo Humano"}

A globalização remete a um novo tempo, a uma situação social, econômica, política e cultural que se inscreve na história da sociedade atual. Há, dessa forma, uma relação entre contemporaneidade e globalizaçáo, ambas seguidas de mudanças quanto aos avanços tecnológicos, às formas de organizaçáo da produção e da comercializaçáo e à aceleração do processo de internacionalização do capital.

Didaticamente, dois períodos marcam as sociedades globais: após a Segunda Guerra Mundial (1939-1945), época em que a industrialização se espalhou pelo mundo; depois da Guerra Fria (1946-1989), momento marcado pelo desenvolvimento do capitalismo pelo mundo, pela queda do muro de Berlim e pela separação do bloco soviético (SEVERIANO; ESTRAMIANA, 2006).

De forma ampla, a globalização pode ser entendida como a integraçáo progressiva das economias e das sociedades, apresentando uma dimensão social e econômica que se refere ao impacto que este processo tem na vida dos indivíduos, assim como em suas famílias. Isso inclui as preocupaçóes e os problemas associados ao emprego, as condiçóes de trabalho, 
além de questóes relativas à seguridade, à cultura e à identidade, à inclusão e à exclusão social.

Com a globalização, há um predomínio do nomadismo, da individualização, da cultura instantânea, da mentalidade em curto prazo. Bauman (2001) denomina a sociedade contemporânea de Modernidade Líquida, pois, assim como os líquidos, a sociedade não mantém a sua forma com facilidade. Instituições, códigos, regras, estilos de vida, crenças se movem constantemente, antes mesmo de se solidificarem em costumes, hábitos e verdades.

Para o autor, nessa sociedade movida pela globalização os sujeitos não possuem raízes, suas qualidades são móveis, descartáveis e substituíveis, uma vez que tentam se adaptar a uma realidade flexível em um mundo cada vez mais individualizado. São sujeitos localizados em um ambiente social fluido e atravessado por novas formas de controle social.

Porém, há algumas "sombras" que acompanham o processo de globalização, como as populaçóes supérfluas, os excedentes, os lixos, os refugos humanos. Bauman (2005, p. 13) destaca que "a globalização se tornou a terceira - e atualmente a mais prolífica e menos controlada 'linha de produçáo' de refugo humano ou de pessoas refugadas". Os refugos são seres humanos que não se encaixam nos novos modelos de Modernidade Líquida, sendo, portanto, considerados "lixos humanos".

Na Modernidade Líquida há uma diminuição da força de trabalho, "há uma necessidade de menos (e cada vez menos) pessoas para manter o movimento, acelerar e atingir o topo" (BAUMAN, 2005, p. 24). Em outras palavras, o mercado não necessita mais de um grande número de pessoas para a sua força de trabalho. Um dos efeitos desse processo é a geração de "resíduos humanos".

Bauman (2005) explica que o progresso tem deixado à margem vítimas colaterais, pessoas consideradas supérfluas, excluídas, descartáveis, verdadeiros "resíduos humanos", já que não são necessários do ponto de vista produtivo. São os desempregados. Sem dinheiro, eles não podem ser considerados consumidores. Ou seja, como não são participantes do processo de circulação de mercadorias, os "excedentes" simplesmente sobram, porque são invalidados pelo sistema econômico e social vigente. Eles são separados do resto da sociedade.

Ser um desempregado pode levar ao "status" de "consumidor falido", incompleto ou frustrado, algo socialmente inaceitável. Para quem foi excluído como "refugos humanos" não existem caminhos (BAUMAN, 
2005) que o permita ascender à condição social de membros de pleno direito. Nesse contexto, insere-se o limpador de para-brisa, um sujeito excedente que passa a sobreviver a partir de uma economia informal, oferecendo seus serviços em esquinas e semáforos das ruas.

\section{0 espaço público, a esquina e o semáforo}

Um dos usos de um espaço público, como as ruas da cidade do Rio de Janeiro, tem a ver com a mobilidade social permanente. Ao tratar sobre espaço público aqui, remete-se ao local, geralmente, aberto, náo privado (é administrado pelo Estado), utilizado pela coletividade. Ele abrange "ruas, becos, largos, praças, jardins e espaços afins que conformam a estrutura urbana não privada” (ALMEIDA, 2006, p. 3).

Nesse sentido, o espaço público é o lugar destinado ao uso público, isto é, acessível a todos, para todos, e que com suas condiçóes legais são considerados propriedade pública. Portanto, é o lugar onde se desenvolve a vida urbana, de relação e de identificação, de manifestaçóes políticas, culturais e de expressão comunitária.

O espaço público é um lugar de passagem do sujeito que o usa para algum fim cotidiano e pessoal, habitando-o transitoriamente em horários e momentos estabelecidos conforme os seus próprios motivos. Porém, existe outro uso do mesmo espaço público: quando o indivíduo elege a rua como o seu local de trabalho. Aqueles cujos meios de inserção social e de trabalho se encontram desamparados, fora de qualquer instância que regule seu ingresso ou outros parâmetros formais de pertencimento.

O trabalho realizado nos espaços públicos, em particular o trabalho do limpador de para-brisa, está ligado a um tipo de apropriaçáo urbana. Lefebvre (2001) ressalta que a sociedade tem o direito de dispor de um espaço público onde possa expressar e intervir segundo suas necessidades, tanto coletivas como individuais. Nas palavras do próprio autor, "o direito à cidade não pode ser concebido como um simples direito de visita ou de retorno às cidades tradicionais. Só pode ser formulado como direito à vida urbana, transformada, renovada" (LEFEBVRE, 2001, p. 117).

Os limpadores de para-brisa tiveram de desenvolver estratégias para intervir na rua, que se mostra como um espaço possível de ocupação e de apropriaçáo sem que isso implique um custo econômico, um 
questionamento da sua identidade dentro de certa burocracia, salvo em alguns casos, como quando a polícia ou guardas municipais interferem no espaço público.

O semáforo como uma referência do espaço público é um instrumento que controla o tráfego de veículos e pedestres. No entanto, circunstancialmente, também tem servido como um lugar de comércio e de cenário artístico para aqueles que querem se apresentar. É um espaço que dá abrigo a quem deseja ocupá-lo para esses fins, trabalhando no ritmo de uma intermitência sistemática.

Atualmente, o semáforo se configura com certa ambiguidade ante a sociedade, já que o condutor prevê encontrar naquele espaço não apenas a luz vermelha ou verde que indica uma norma a seguir, mas também se deparar com o vendedor de doce, o limpador de para-brisa, o jogador de malabares bolas e tacos, o artista, que são estigmatizados socialmente.

Não se pode perder de vista que este fenômeno revela uma problemática de exclusão social em relação às condiçóes de trabalho e dos direitos humanos. Do ponto de vista da lei, "a exclusão é um ato de autossuspensão. Isso significa que a lei limita sua preocupação com o marginalizado/ excluído para mantê-lo fora do domínio do governado pela norma que ela mesma circunscreveu" (BAUMAN, 2005, p. 43).

No semáforo, juntam-se indivíduos que vieram de outras regióes da cidade e do país em busca de melhores condiçóes de vida, mas que não conseguem trabalho; indivíduos oriundos de lugares desfavorecidos econômico e socialmente; desempregados que vislumbram uma forma de renda no semáforo. A impossibilidade de o governo gerar políticas públicas eficientes voltadas para o emprego e a incapacidade de incluir as minorias nos "padróes" de dignidade humana favorecem a concentração dessa população em determinados espaços, reconfigurando-os simbolicamente.

Esses lugares simbólicos seriam o que Lefebvre (1991) chama de "espaços vividos", isto é, "são os espaços diretamente vividos pelos usuários e habitantes do espaço" (LEFEBVRE, 1991, p. 39). Neles, há uma maior subjetividade dos indivíduos, uma vez que afloram os sentimentos vivenciados pela experiência espacial, determinando, nesse caso, uma nova espacialidade ou reafirmando práticas socioespaciais realizadas por eles.

Assim, o semáforo, espaço destinado a regular o trânsito, traz novas significaçôes. As práticas desenvolvidas nesses espaços possuem normas e regras. Por exemplo, diferentemente de uma praça - onde as intervençóes são mais duradouras - nas ruas, no semáforo, a intervenção é pautada 
pelas luzes. Cada luz vermelha representa uma nova possibilidade de o sujeito repetir sua ação frente aos motoristas.

Os sujeitos que oferecem seus serviços nas esquinas e nos semáforos do Rio de Janeiro, com exceçôes de alguns casos, estáo condicionados pelas oportunidades básicas que lhes foram negadas e que continuam a ser negadas.

\section{A atividade do limpador de para-brisa}

O fenômeno em torno dos limpadores de para-brisa vem ganhando maior notoriedade, porque as ruas do Rio de Janeiro têm sido "inundadas" por esses grupos que, na maioria das vezes, estáo em busca de algum dinheiro. É um grupo heterogêneo, composto por pessoas com realidades distintas, mas que possui em comum o não pertencimento à sociedade dita "formal".

Existem alguns fatores que podem levar o indivíduo a se tornar um limpador de para-brisa: a perda de um emprego; o "rompimento" de algum laço familiar; sujeitos que chegaram à cidade e, ainda, não conseguiram um emprego etc. Assim, devido a algum acontecimento que tenha afetado suas vidas, esses indivíduos vão aos poucos perdendo a perspectiva de uma vida melhor, passando a utilizar o espaço público, a rua, como sobrevivência.

Observando os limpadores de para-brisa, surgem alguns aspectos a destacar, como por exemplo, muitas vezes trabalham em grupo de duas ou três pessoas. Existem, no interior de cada grupo, estratégias diferenciadas. Alguns tentam oferecer o serviço a vários motoristas a cada mudança de luz do semáforo; outros preferem convencer um ou dois a cada mudança de sinal fechado.

Era um ramo exclusivo dos homens, porém pode-se já notar a inserção de mulheres. São homens, crianças, jovens, que realizam o serviço de limpeza de para-brisa, em troca de uma colaboração voluntária do motorista. Esse grupo não tem um local fixo, já que ele vai em busca dos possíveis interessados.

As tarefas envolvidas no trabalho são relativamente fáceis de aprender e não necessitam de mais itens do que um balde, um pano, um rodo e, em alguns casos, um pouco de detergente. Às vezes, algumas dessas ferramentas são adaptadas de outros objetos, como por exemplo, uso de lata de 
tinta como balde; vidros de desodorante ou garrafas como recipientes para armazenar os detergentes; a própria camisa como pano para secar o rodo.

Assim que o sinal fecha, os limpadores de para-brisa se dirigem até o automóvel. Há certos códigos entre eles que devem ser respeitados. Por exemplo, se um integrante se aproxima de um carro, outro náo pode intervir. Diante do carro, molham o para-brisa (ação que é realizada, às vezes, sem a permissão do motorista, o que gera graus de violência verbal, tanto por parte do motorista quanto do limpador de para-brisa) com uma mistura de água e detergente e, em seguida, passam o rodo, fazendo movimentos circulares para retirar o excesso de água. Ao finalizarem a limpeza, estendem a mão, pedem uma contribuição, utilizando frases como: "dá uma ajudinha aí pra o irmão comprar uma comida”.

Entretanto, o contato com o motorista é tão efêmero que, na maioria das vezes, ambos se mantêm no anonimato. É como se o espaço da esquina, do semáforo, fosse um "não lugar" (AUGÉ, 1994). Segundo este autor, "[...] se um lugar pode se definir como identitário, relacional e histórico, um espaço que não pode se definir nem como identitário, nem como relacional, nem como histórico definirá um não lugar" (AUGÉ, 1994, p. 73). O "não lugar" corresponde a lugares de passagem, de consumo, de trânsito, de circulação (autoestradas, lojas de conveniência, supermercados, shopping, postos de gasolina etc.).

É importante entender o contexto dentro do qual Augé (1994) utiliza o termo "lugar". Para ele, o "lugar" é um espaço fortemente simbolizado, ou seja, é um lugar em que se pode ler, em parte ou em sua totalidade, a identidade dos que o ocupam. É sinônimo de identidade, porque está cheio de afetos, tradiçóes, como uma história. Então, o que Augé quer dizer é que há lugares sem identidade (os "não lugares") por parte dos seus usuários e que estes são sinais da pós-modernidade. Tais lugares permitem apenas uma troca de olhar entre pessoas condenadas a não se encontrarem novamente.

Porém, ao contrário do que é defendido por Augé (1994), os limpadores de para-brisa podem criar raízes ao longo do tempo. Na medida em que a permanência nesses espaços seja maior para alguns e a ocupação desses locais gire em torno de uma atividade específica, manifestando-se algumas características de pertencimento através da atividade realizada.

O trabalho do limpador de para-brisa guarda uma dupla condição: por um lado, pode ser pensada como prestação de serviço, a limpeza do para-brisa do carro; por outro lado, também pode ser vista como uma 
invasão de privacidade - neste caso, dos limpadores aos motoristas - que para recusar a receber o serviço, o motorista deve fazê-lo de forma enfática e rápida para impedir o início da limpeza.

Há de se ressaltar ainda que, no imaginário social, associam o limpador de para-brisa à delinquência, ao vício e à droga, e, assim, são evitados pelos motoristas que temem ser assaltados, fechando as janelas do carro para não estabelecerem nenhuma relação com eles. Esse grupo é táo vitimizado que alguns integrantes começam a vender produtos ou aprender malabares para escapar da estigmatização de ser um limpador de para-brisa.

\section{O limpador de para-brisa e a criaçáo do seu direito à cidade}

Os limpadores de para-brisa formam parte de uma categoria de trabalhadores que sempre existiu, apesar das iniciativas frequentes para reprimi-los. Porém, observa-se que o número deles tem aumentado, o que pode ser explicado tanto devido ao êxodo generalizado de trabalhadores pouco qualificados para as cidades, quanto em função da falta de oportunidade de empregos nos grandes centros urbanos.

Essas pessoas são tratadas, muitas vezes, como criminosas e tidas como um obstáculo ao desenvolvimento das cidades. "São consideradas, sobretudo um problema financeiro. Precisam ser 'providas' - ou seja, alimentadas, calçadas e abrigadas" (BAUMAN, 2005, p. 20-21). Elas já não podem ser integradas funcionalmente ao sistema moderno de vida, ainda que em algum momento do processo sejam necessárias para a própria sobrevivência do sistema.

Bauman (2005) salienta que, anteriormente, esses "resíduos humanos" eram desviados e reabsorvidos por outros lugares que ainda não tinham atingido o processo de globalização. No entanto, nas condiçóes atuais da globalização, de extensão da modernidade para todas as áreas do planeta, os espaços não globalizados também estão "lotados" de "resíduos supérfluos".

A eliminação ou, pelo menos, a "invisibilização" - de resíduos indesejados tornou-se um dos principais problemas das sociedades contemporâneas. "Eles são removidos da maneira mais radical e efetiva: tornando-os invisíveis, por não olhá-los [sic], e inimagináveis" (BAUMAN, 2005, p. 38 ), por não se pensarem neles. Somente chamam a atenção quando são rompidas as defesas elementares da rotina, colocando a sociedade em perigo. 
Os limpadores de para-brisas fazem parte desta população invisível, sistematicamente excluída dos benefícios da vida moderna, deserdada da modernidade, um "lixo humano", como assinala Bauman (2005). Alguns os veem como delinquentes ou bandidos, que como tal representam ameaças à sociedade; outros os encaram como vítimas de um sistema econômico e social excludente. Pode-se dizer que a economia os expulsou da sociedade, não gerando condiçóes para a sua incorporação.

Assim, em função das transformaçóes socioeconômicas, sujeitos que não conseguem se "enquadrar", seguir as regras de determinada sociedade, acabam sendo desprovidos dos direitos básicos de sobrevivência. Os limpadores de para-brisa não cabem na cidade; são "privados" de usufruir dos benefícios oferecidos pela cidade: "educação, saúde, trabalho, moradia, lazer, segurança, previdência social” (BRASIL, 1988), ou seja, do direito à cidade. Dessa forma, eles produzem pelas próprias mãos o seu direito à cidade, de modo ilegal.

Segundo Lefebvre (2001), uma forma superior de direitos é o direito à cidade, uma vez que contém nele outros direitos como "direito à liberdade, à individualização na socialização, ao habitat e ao habitar. O direito à obra (à atividade participante) e o direito à apropriaçáo (bem distinto do direito à propriedade)" (LEFEBVRE, 2001, p. 134). É um direito que implica a motivação de uma cidadania para construir a cidade de modo coletivo, como parte de um projeto comum. Direto de apropriar-se do espaço urbano, ou seja, o direito de viver, de participar e de tomar decisóes em relação à produção do espaço urbano.

Tal espaço permite a invenção de mecanismos com os quais o indivíduo pode se expressar e, por conseguinte, criar dinâmicas coletivas destinadas a repensar a cena pública. Como ressalta Lefebvre (2001), “[...] o direito à cidade náo pode ser concebido como um simples direito de visita ou de retorno às cidades tradicionais. Só pode ser formulado como direito à vida urbana, transformada, renovada”.

Relacionando as ideias de Lefebvre (2001) com o trabalho do limpador de para-brisa pode-se dizer que essa população não é um "lixo humano". Ao contrário, ela criou, e cria, pelas próprias máos o seu direito à cidade, enquanto prática social e espacial, transformando-a para que ela se mantenha viva. Tal ocupaçáo informal não só está ligada à ideia que tem o indivíduo urbano de dispor de uma cidade acolhedora e amável. Tem a ver também com um espaço onde ele se torna um sujeito ativo.

Os limpadores de para-brisa transformam as esquinas, os semáforos, conferindo a esses espaços novos significados, ou melhor, "lugares 
praticados”, como salienta Certeau (1994, p. 202). Lugares em que há "um cruzamento de móveis [...] animado pelo conjunto de movimentos que aí se desdobram.” Portanto, praticar lugares é habitá-los, organizá-los e modificá-los. Por isso, são construídos e estão em constante evolução. E é a criatividade a marca que caracteriza os espaços vividos.

Cada cidade é um espaço simbólico em construção que é transformado pelos indivíduos que a habitam, que transitam e vivem nela. Cada maneira de construí-la, é também uma forma de habitá-la. Habitar um espaço não é simplesmente permanecer nele, mas modificá-lo. O limpador de para-brisa intervém na transformação do "não lugar" (da esquina, do semáforo) em espaço de trabalho e, portanto, dá um significado que antes náo existia por meio da representação do espaço, de sua reformulaçáo.

Já que os limpadores de para-brisa não conseguem fazer parte da cidade de maneira legal, eles criam estratégias informais para terem direito à cidade. $\mathrm{O}$ serviço que exercem os reposicionam no centro da cidade, sendo uma alavanca de reconstrução desse espaço. Em outras palavras, esses trabalhadores usam a infraestrutura urbana existente e desenvolvem práticas em busca de soluçóes, para os problemas sociais vigentes.

\section{Consideraçóes finais}

A presença dos limpadores de para-brisa nas cidades, nos grandes centros urbanos, não deve ser explicada apenas como uma estratégia informal de emprego, mas também como resposta a um processo de crescimento acelerado das cidades. Sujeitos migraram para a cidade e a maioria deles acabou vitimizada em cidades sem oportunidades. Assim, ao referir-se ao limpador de para-brisa no Rio de Janeiro, significa evocar as causas e as consequências da globalização sobre as cidades.

O desamparo a que esses trabalhadores se veem imersos atravessa a sua vida cotidiana. Eles foram privados do acesso aos serviços sociais básicos: educação, saúde, trabalho, moradia etc. São perseguidos e estigmatizados por vários setores sociais. Como são excluídos da cidade, produzem pelas próprias máos o seu direito à cidade, transformando-a e renovando-a, buscando soluçóes para os efeitos negativos da globalização, como a exclusão de indivíduos do mercado formal de trabalho.

"Ser pobre não é sinônimo de ser um criminoso". A maioria dos limpadores de para-brisa são sujeitos desprovidos de bens materiais, vivendo em 
uma situação de dificuldade econômica e social. Portanto, ser um limpador de para-brisa não significa ser um criminoso. Esta é uma clara tentativa de criminalizar a pobreza por aqueles que não têm interesse ou preocupação com a situação dos menos favorecidos.

Não basta que os limpadores de para-brisa sejam incluídos em programas do Governo, que muitas vezes não oferecem garantias em termos de ingresso ao mercado de trabalho para continuar o seu sustento. $\mathrm{O}$ que deveria existir é uma reforma urbana integral, a fim de assegurar condiçóes dignas de vida para sujeitos que moram na cidade e em outras localidades mais afastadas do centro urbano; maneiras de incorporá-los ao setor produtivo e de fazê-los ter direito à cidade, de serem usuários dos serviços sociais existentes. Enquanto isso não acontecer, tais indivíduos continuarão sendo perseguidos e tratados como marginais, delinquentes, "resíduos humanos".

\section{Referências}

ALMEIDA, Maria Cecília Fernandes de. Espaços Públicos em Joáo Pessoa (1889-1940): Formas, Usos e Nomes. Sáo Paulo, 2006. Dissertação (Mestrado em Arquitetura e Urbanismo) - Escola de Engenharia de São Carlos, Universidade de São Paulo. Disponível em: <http://www.teses.usp.br/teses/ disponiveis/18/18142/tde-29012007-114542/pt-br.php>. Acesso em: 10 jun. 2016.

AUGÉ, Marc. Náo lugares: introdução a uma antropologia da supermodernidade. Campinas: Papirus, 1994.

BAUMAN, Zygmunt. Vidas Desperdiçadas. Tradução de Carlos Alberto. Rio de Janeiro: Jorge Zahar Editor, 2005.

Modernidade Líquida. Rio de Janeiro: Jorge Zahar, 2001.

BRASIL. Constituição (1998). Constituição da República Federativa do Brasil: promulgada em 5 de outubro de 1998: atualizada até a Emenda Constitucional ${ }^{\circ}$ 20, de 15-12-1998.

CERTEAU, Michel de. A invenção do cotidiano: artes de fazer. Petrópolis: Vozes, 1994.

LEFEBVRE, Henri. O direito à cidade. São Paulo: Centauro, 2001. 
The Production of Space. Tradução de Donald Nicholson-Smith. Oxford: Blackwell Publishing, 1991.

SEVERIANO, Maria de Fátima; ESTRAMIANA, José Luiz. Consumo, Narcisismo e Identidades Contemporâneas. Rio de Janeiro: Editora UERJ, 2006. 


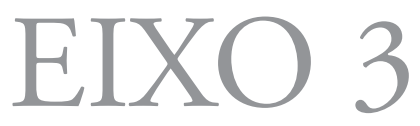

Desenvolvimento regional, agroecologia e sustentabilidade 


\title{
VIA CAMPESINA X ORGANISMOS \\ MULTILATERAIS: A LUTA PELA \\ SOBERANIA ALIMENTAR ${ }^{1}$
}

\author{
Igor Tairone Ramos dos Santos ${ }^{2}$ \\ Arlete Ramos dos Santos ${ }^{3}$
}

\section{Introduçáo}

De acordo com Marx (2005), o trabalho é a condição de existência do homem, cujo principal fator para manutenção desta trata-se da mediação homem e natureza a partir das relaçóes de produção. No momento em que o homem passou a dominar os meios de produçáo como propriedade privada, inclusive a terra, surgiram as desigualdades sociais, e a maneira como essa relação é perpassada pelo tempo foi decisiva para formaçáo da estrutura capitalista. No que se refere à propriedade privada da terra, com base nos estudos de Marx (2002), pode-se concluir que a mesma não possui valor, não é capital, já que não é produto do trabalho humano. Porém, a apropriação privada desse bem natural nas máos de poucos produtores faz com que estes detenham o controle sobre a sua utilização, transformando-a numa mercadoria.

A apropriação privada desse meio de produção por parte das grandes empresas capitalistas durante os incentivos neoliberais da Organização

1 Trata-se de um recorte da pesquisa "Análises Feministas da Agenda de Desenvolvimento pós-2015: a Atuação das Mulheres em Movimentos Agrários no Brasil, em desenvolvimento no Grupo de Estudos sobre Igualdade de Gênero", com a orientação da professora Xaman Koraii, da Universidade Federal da Paraíba - UFPB.

2 Graduando do curso de Relaçóes Internacionais da UFPB, bolsista voluntário no Programa Institucional de Voluntariado em Iniciação Científica-PIVIC e membro da Liga de Estudos de Direito Internacional Oswaldo Aranha.

3 Doutora em Educação (FAE/UFMG), professora adjunta do Programa de Pós-Graduação - Mestrado em Formação de Professores para a Educação Básica (DCIE/UESC). Coordenadora do Centro de Estudos e Pesquisas em Educação e Ciências Humanas CEPECH; Coordenadora do Grupo de Estudos Movimentos Sociais, Diversidade Cultural e Educação (UESC). E-mail: <arlerp@hotmail.com>. 
Mundial de Comércio - OMC e da Organização das Nações Unidas para Agricultura e Alimentação - FAO teve como consequência a expulsão dos camponeses ${ }^{4}$ das terras utilizadas para a agricultura de subsistência, e da correlação de forças entre trabalhadores e capitalistas, no campo, surgiram vários movimentos sociais agrários, dentre eles, a Via Campesina, com objetivo de lutar pelo direito à terra. O termo 'movimentos sociais' foi criado por Von Stein, em 1840, a partir de uma leitura da emergência do mundo urbano-industrial, e tem sido usado sob várias denominaçóes no Brasil. Quer seja para designar qualquer ação coletiva de forma ampla, ou mesmo para designar estritamente mobilizaçóes reivindicativas da sociedade civil (SANTOS, 2013).

A Via Campesina é uma rede de movimentos agrários com articulação mundial, que surgiu em 1992, no mês de abril, com o objetivo de empoderar ${ }^{5}$ camponeses e mulheres no combate à entrada maciça da neoliberalização na agricultura. Luta também contra a influência da OMC na condução das políticas agrícolas dos Estados, pois as medidas que tal organização toma, como abertura econômica massiva, isenção tributária sobre o acesso à terra e aos negócios para exclusão de barreiras econômicas, tendem a favorecer as grandes multinacionais a expandir sua produçáo de maneira que prejudica a vida dos pequenos agricultores, em prol de um sistema que tende à desigualdade. Sua fundação foi decidida no II Congresso da UNAG - Unión Nacional de Agricultores y Granaderos, de Nicarágua, realizado em 1992. Congresso este que segundo Ribeiro (apud Vieira, 2011, p. 188), "Houve a intenção de criar um 'projeto coletivo no qual pudessem desenvolver alternativas ao neoliberalismo". No fim do congresso supracitado, foi criado um documento chamado Declaração de Manágua que estabeleceu as diretrizes que antecederam a fundação oficial da Via Campesina, em Mons, na Bélgica (DESMARAIS, 2007).

4 "A palavra camponês não designa apenas o seu nome, mas também o seu lugar social, não apenas no espaço geográfico, no campo, em contraposição à povoação ou à cidade, mas também na estrutura da sociedade; por isso, não é apenas um novo nome, mas pretende ser também a designação de um destino histórico” (MARTINS, 1999, p. 22-23).

5 Oferecer a "capacidade de os indivíduos e grupos poderem decidir sobre as questôes que lhes dizem respeito, escolher, enfim entre cursos de ação alternativos em múltiplas esferas política, econômica, cultural, psicológica, entre outras" (HOROCHOVSKI, 2006, p. 2). 
Uma das políticas responsáveis pela desigualdade social, no Brasil, foi a Revolução Verde ${ }^{6}$, sobre a qual discutiremos mais à frente, que se destacou como fator primordial na emergência das políticas neoliberais e que despertou a açáo de movimentos agrários, porque boa parte da produção agrícola dos países voltou-se para o abastecimento externo, prejudicando a economia interna e aumentando a desigualdade social. Como tal problema tomou proporçôes internacionais, fez-se necessário a interferência da FAO na tentativa da busca de Segurança Alimentar, sendo este também um conceito que será discutido durante o desenvolvimento do presente artigo, mas, inicialmente, salientamos que este se tornou um conceito em notoriedade, principalmente, no período pós-guerras, já que a fome estava dominando uma parcela considerável de países. Entretanto, as políticas organizadas pelas subdivisóes da Organização das Naçôes Unidas - ONU, como a FAO e a OMC, não conseguiram por si só resolver o problema da fome e da extrema desigualdade social (CAMARGO, 2013). Devido a este contexto, surgiram, nos anos 80, movimentos sociais $^{7}$ de luta contra a concentração de terras, tendo como pauta também a segurança e a soberania alimentar, já que as políticas impostas pelas grandes organizaçóes estavam capitalizando a agricultura, à medida que as grandes multinacionais do agronegócio se apropriaram da terra para reproduzirem em larga escala.

A Via Campesina tem sido, desde entáo, o movimento social que tem recebido mais destaque pela sua capacidade de representação da voz camponesa pelo mundo (FAO, 2013), de forma que tem obtido reconhecimento inclusive das grandes organizaçóes, principalmente, a FAO e, juntamente com esta, vem traçando alternativas através de protestos, manifestaçóes e acordos, para lutar pela soberania alimentar dos países e pelo direito de produçáo e visibilidade do pequeno agricultor.

6 As lutas relacionadas ao campo no Brasil contemporâneo têm como contribuiçóes teóricas autores como Grzybowsky (1991), Medeiros (1989), Martins (1999), Fernandes (1996), Stédile (2005), Ribeiro (2010), dentre outros.

7 MPA - Movimento dos Pequenos Agricultores, La Via Campesina, Associação de Comunidades da Diáspora Africana por Direito à Alimentação - Rede Kodya, entre outros. 


\section{Mudanças no cenário agrário-econômico}

Antes e depois que as grandes guerras ocorreram, muitos países ainda eram colônias e tinham suas economias baseadas na agricultura. Então, quando o conflito se encerrou, criou-se uma nova demanda por alimentos, e os governos dos Estados mais fragilizados pelas debilidades na agricultura iniciaram um processo de apropriaçáo das terras por grandes corporaçóes com o intuito de aumentar a produção. Este processo, chamado de Revolução Verde, surgiu com o objetivo de solucionar a crise alimentícia que havia tomado conta do mundo neste período, entre os anos de 1970 e 1980, que além da apropriação da terra, como já citado, criou novos mecanismos científicos de manipulação genética, para aumento da produção, bem como a liberalização do comércio nos países, principalmente, aqueles que haviam deixado de ser colônias e tinham a agricultura como principal fonte de renda (NIEMEYER, 2007).

Existe um processo implícito, segundo Desmarais (2013), de confiança excessiva na ciência, a respeito da produção de conhecimento na agropecuária, ciência esta que está basicamente a serviço das grandes empresas e do agronegócio ${ }^{8}$ como um todo, que faz com que os camponeses comecem a perder influência na produção do campo, já que o conhecimento científico a respeito da produção levaria a uma maior quantidade de alimentos e produtos finais produzidos. Sobre este processo, Vieira (2011) versa sobre a concentraçáo de capital e terras nas mãos de multinacionais, ocasionada pela neoliberalização da agricultura, afirmando que

esta concentração não seria apenas na produçáo, mas também na distribuição dos produtos, acabando por homogeneizar até mesmo o consumo de alimentos no mundo. O processo se estenderia para a concentração de terras e seu resultado seria a expulsão de trabalhadores do campo ou o empobrecimento e total dependência dos pequenos agricultores em relaçáo às grandes empresas capitalistas (VIEIRA, 2011, p. 43).

8 De acordo com Oliveira (2010), agronegócio é a "soma total de todas as operaçôes envolvendo a produção e distribuição de suprimentos agrícolas; as operaçôes de produção dentro da fazenda; o armazenamento, processamento e distribuiçáo de produtos agrícolas e dos itens produzidos a partir deles" (p. 15). 
O que auxiliou este processo foi a criação de Organizações Internacionais, dentre elas a OMC, que tinha o objetivo de assegurar os direitos de propriedade intelectual, já que algumas empresas estavam produzindo sementes e animais geneticamente modificados. A Organização Mundial da Propriedade Intelectual-OMPI nasceu da já existente BIRPI - Bureaux Internacionaux Reunis pour la Protection de la Proprieté Intelectulell e teve um aumento em seu alcance por conta de sua ação vinculatória nos Estados sob a forma dos TRIPS - Agreement on Trade-Related Aspects of Intellectual Property Rights. Para os países fazerem parte da OMC, esses são obrigados a assinar esse tratado, sendo assim, há uma nova propagação desse método de liberalização, além de uma grande centralização deste conhecimento nas mãos de poucas empresas, contribuindo na manutenção das relaçôes desiguais de renda e na concentraçáo fundiária, bem como, a desigualdade do acesso ao capital produzido da agricultura (SOUZA, 2005).

Segundo Desmarais (2007), os acordos de livre comércio regionais, bilaterais, como os da OMC se tornaram poderosas ferramentas na modificação do cenário econômico-agrário, já que promovem a concentração de terras nas mãos de poucas empresas, em detrimento dos pequenos camponeses. A agricultura familiar ${ }^{9}$ perde gradativamente, então, espaço para as grandes produçóes em escala, das transnacionais, estas, utilizando-se em parte de novos métodos de aumento da produçáo, principalmente, da manipulação genética de animais e plantas.

Os acordos de livre comércio, propostos pela OMC, ao invés de promover a diminuiçáo da pobreza e o acesso a um mercado de modo justo para o camponês o insere em um mercado hipercompetitivo em escala mundial, através da exclusão de fronteiras econômicas e diminuição de tarifas e impostos para as empresas, no qual, tal camponês, não tem condição de competir justamente. Todavia, esse mesmo mercado impulsiona as próprias empresas a se fundirem e se tornarem cada vez maiores, eliminando a própria competição no sistema econômico mundial (DESMARAIS, 2013).

\footnotetext{
9 A agricultura familiar caracteriza-se pela relação entre terra, trabalho e família, e apresenta uma série de especificidades e diferenciação regional/local que assegura sua inserção e reprodução na sociedade contemporânea. [...] Caracteriza-se pelo controle da família sobre os meios de produção e ao mesmo tempo é a principal responsável pela efetivação do trabalho (LAMARCHE, 1993).
} 


\section{A Segurança Alimentar e o Direito Internacional}

De acordo com Maluf, Menezes e Marques (2012), o conceito de Segurança Alimentar surgiu no contexto pós-guerras, onde era perceptível que os países poderiam dominar a produção alimentar um do outro. Sendo assim, através dessa dominaçáo havia implicitamente uma insegurança do país dominado no que diz respeito à sua alimentação, já que, muitas vezes, esse náo tinha capacidade de produzir a quantidade de alimentos para sua população. Isto ainda poderia funcionar, também, como projeção de poder de uma naçáo mais desenvolvida sobre a outra que sofria com dependência do fornecimento alimentar externo.

Segundo a FAO (2009),

a segurança alimentar e nutricional consiste na realização do direito de todos ao acesso regular e permanente a alimentos de qualidade, em quantidade suficiente, sem comprometer o acesso a outras necessidades essenciais, tendo como base práticas alimentares promotoras de saúde, que respeitem a diversidade cultural e que sejam social, econômica e ambientalmente sustentáveis (LOSAN, Art. 3º).

Na I Conferência de Segurança Alimentar, organizada pela $\mathrm{FAO}^{10}$, em 1974, começou a haver uma mudança neste entendimento, pelo fato de que os países estavam atravessando sérios problemas de abastecimento, em grande parte por conta das guerras ocorridas; e ao tentar solucionar esse problema surgiu a ideia por parte do sistema capitalista, representado pela FAO, com a implementação da Revoluçáo Verde, que procurou, através da utilização maciça de insumos e fertilizantes, além da neoliberalização da agricultura, solucionar o problema da fome, já que o objetivo seria aumentar a produçáo. No entanto, os resultados esperados não foram obtidos, já que a segurança alimentar não chegou à parcela da população mundial como o esperado e prometido, além de ter contribuído para o aumento da desigualdade social.

${ }^{10}$ A Organização das Naçóes Unidas para a Alimentação e a Agricultura (FAO) é uma organizaçáo intergovernamental que conta com 194 Estados Membros, dois membros associados e uma organização membro, a União Europeia. A sede da FAO fica em Roma, Itália. 
De acordo com a FAO, conseguir alcançar a segurança alimentar deve ser um objetivo que norteie as políticas públicas dos países, bem como as suas estratégias de desenvolvimento. O Estado deve, então, respeitar as duas esferas do desenvolvimento que se tratam do direito à alimentação e nutrição adequada, e do direito a estar livre da fome e da má nutrição. Percebe-se que tal direito é de grande importância, visto que é reconhecido desde a Declaração Internacional dos Direitos Humanos, de 1948, ao Pacto Internacional dos Direitos Econômicos, Sociais e Culturais (PIDESC), de 1966, onde os Estados reconhecem, dentre estas, outras questóes relativas aos direitos humanos, mas, principalmente, o direito à alimentação (FAO, 2013).

A FAO aprovou, em 2004, as diretrizes voluntárias do direito à alimentação, as quais tiveram o objetivo de auxiliar os países no alcance das metas relativas à erradicação da fome, principalmente, porque esse direito está inserido no contexto estatal, juridicamente, através de pactos e tratados. Um desses pactos, o Pacto de Sunt Servanda, segundo a Revista Âmbito Jurídico, versa que "os contratos uma vez celebrados livremente, incorporam-se ao ordenamento jurídico, passando a vigorar como se fossem verdadeiras normas jurídicas" (BRASIL, 1990, p. 1). Sendo assim, seus descumprimentos podem acarretar sançóes no plano internacional.

A vinculação de direitos humanos nas Constituiçóes dos países que participam dos acordos internacionais se torna um passo fundamental para o alcance de seus objetivos, e pela metodologia da FAO (2009), esta vinculação pode acontecer de três maneiras:

Reconhecimento explícito ou directo, como um direito humano em si mesmo, ou como parte de um direito humano mais lato; Reconhecimento implícito através da interpretação de outros direitos humanos e Reconhecimento como um princípio ou directriz constitucional (FAO, 2009, p. 1).

Como exemplo de interpretação, o direito à alimentação pode ser apresentado como um direito à vida em si, já que versa sobre a alimentação, ato necessário à vida, no entanto, a Constituição Brasileira é a única que apresenta lei específica para o campo da Segurança Alimentar e Nutricional:

Art. 20: A alimentação adequada é um direito humano fundamental do ser humano, inerente à dignidade da pessoa humana e indispensável à realização dos direitos consagrados 
na Constituição Federal, devendo o poder público adoptar [sic] as políticas e acções [sic] que se façam necessárias para promover e garantir a segurança alimentar e nutricional da população (BRASIL, 1998).

\section{Impulsionar a luta: a Via Campesina e a Segurança Alimentar}

De acordo com Vieira (2011, p. 5), a Via Campesina “[...] se desafia a formular propostas em relação aos seguintes temas: reforma agrária, biodiversidade e recursos genéticos, soberania alimentar, direitos humanos, agricultura camponesa sustentável, migração e trabalhadores rurais, questão de gênero". Por isso, trata-se de um movimento contra-hegemônico que após o avanço maciço da globalização tem procurado lutar para solucionar problemas que definem negativamente a estrutura social.

A Via Campesina surgiu num contexto histórico onde estava havendo um constante aumento dos processos de mercantilizaçáo, bem como o crescimento do comércio transnacional, e este acontecia sob a forma da exploração de commodities fez com que vários camponeses sofressem os impactos negativos desse processo. Dentre tais consequências podem ser expostas: o êxodo rural, constante desapropriação de terras dos camponeses para grandes multinacionais. Os camponeses que não perderam suas terras não tinham condiçóes de competir com a produção das multinacionais, ocasionando grandes dificuldades econômicas que foram o grande impulso para a formação da Via Campesina (VIEIRA apud RIBEIRO, 2011).

De acordo com Vieira (2011, p. 1), a Via Campesina é formada da seguinte maneira:

A Conferência Internacional (CI) é o órgão principal da Via
Campesina, pois nessa delibera-se as políticas do Movimento,
reunindo-se a cada 4 anos em lugares diferentes a fim de atin-
gir todas as regiôes. O Comitê Coordenador Internacional
(CCI) é escolhido a cada CI, sendo as 8 regiôes representadas
por um coordenador e uma coordenadora de distintos movi-
mento, com intuito de dividir as responsabilidades [...] Os Es-
critórios Regionais (ER) possibilitam as relaçôes e as articula-
çôes em cada região, denominado de 'trabalho central' da Via
Campesina (VIA CAMPESINA, 2006). Por fim, a Secretaria 
Operativa Internacional (SOI) é responsável pela comunicação e pelo cumprimento das resoluções políticas.

Quando se analisa a estrutura orgânica da Via Campesina, percebe-se que esta se organiza de maneira horizontal a fim de promover a participação de todos os militantes no referido Movimento, bem como fugir de um modelo burocrático ${ }^{11}$ que possa tornar difícil a participação mais ativa de todos os camponeses que a constitui. As lutas da Via Campesina se baseiam em "[...] acampamentos, bloqueios, caminhadas, celebraçóes religiosas, cercos a construçôes, concentrações públicas, interdiçóes, jejuns, marchas, romarias, vigílias, ocupaçôes de agências bancárias e de prédios privados e públicos" (VIEIRA, 2011, p. 78), sempre com o objetivo de lutar pela posse da terra e contra os efeitos nocivos do agronegócio. Este Movimento também é conhecido por buscar, além de uma reforma agrária em nível mundial, bem como uma inserção de gênero e o empoderamento feminino na luta da terra, e direitos iguais na cadeia produtiva, sendo de grande importância na consecução da igualdade de gênero, em todas as esferas sociais (DESMARAIS, 2013).

\section{A Soberania Alimentar e a Via Campesina}

O conceito de 'Soberania Alimentar' surgiu na década de 1980, depois que as políticas de neoliberalização da agricultura prejudicaram a vida do pequeno camponês e geraram altos problemas de fome, visto que a agricultura familiar não estava conseguindo superar as dificuldades impostas pela entrada do neoliberalismo na agricultura, expondo os camponeses as altas taxas de competitividade com sua produção, no mercado capitalista. Sendo assim, a FAO, as organizaçóes internacionais dos trabalhadores, como a Via campesina, assim como outras nacionais que não estão presente nesse estudo, vêm tentando superar este problema através da mobilizaçáo pautada em bandeiras que se concretizam no que pode ser compreendido como os conceitos de Segurança Alimentar e Soberania Alimentar.

11 Para um melhor entendimento da organização horizontal nos movimentos sociais do campo brasileiro, ver Santos (2013). 
Soberania Alimentar, de acordo com a Via Campesina, se trata do "direito de cada naçáo de manter e desenvolver sua própria capacidade de produzir alimentos básicos, respeitando a diversidade cultural e produtiva" (VIEIRA, 2011, p. 7). Ao se desenvolver esse conceito ainda consegue-se depreender, de acordo com Maluf; Menezes e Marques (2007), que este conceito se trata de

produzir os alimentos necessários à população em todas as regiōes do mundo, de modo a reduzir a dependência ligada à ajuda alimentar; controlar, conservar e utilizar seus recursos genéticos e seus conhecimentos próprios; garantir a disponibilidade e o acesso de todos a uma alimentaçâo sadia, diversificada e que respeite a diversidade das culturas e hábitos alimentares; tomar decisões de modo autônomo concernentes a suas políticas agroalimentares (p. 20).

No entanto, ainda segundo Vieira (2011), o que é compreendido por Segurança Alimentar para a FAO se configura de maneira incompleta, porque esta aborda que o país deve produzir o necessário para sua subsistência e a subsistência das famílias camponesas, ao passo que a Via Campesina ainda procura a descentralização da agricultura no alcance da segurança alimentar, ou seja, defende não só a produção de alimentos, mas também o controle e a escala da produção, de forma que se saiba como tais alimentos são produzidos (DESMARAIS, 2013).

O que se compreende como Soberania Alimentar se torna algo necessário, porque na tentativa de buscar a segurança alimentar para os Estados, em algumas ocasióes, pode ser mais barato procurar ajuda alimentar de outros possivelmente mais abastados, o que acaba por prejudicar a vida dos camponeses e das pequenas famílias produtoras, visto que sua produção será desvalorizada e dificultada por falta de estímulos e subsídios de seu país.

\section{A relação entre a Via Campesina e a FAO}

A FAO, segundo Camargo (2013), é uma das Organizaçóes Internacionais inserida no sistema da ONU que trabalha principalmente com as questôes relativas à agricultura e à alimentação no mundo e responde também pela produção de alimento nos países. Essa Organização foi criada com 
o objetivo de tentar mitigar os efeitos nocivos da guerra sobre a produção de alimentos nos países, especialmente no que tange à Europa, visto que este continente ficou destruído após a II Guerra Mundial (CAMARGO, 2013). A FAO nasceu em 1945, no Québec, Canadá, e tem sede fixa em Roma, na Itália. A referida Organização precisou adaptar sua estrutura para as mudanças que ocorreram ao passar dos anos, como em 1944, quando era composta por 42 membros, mas, em 2013, já contava com 194 representaçóes.

Em meados dos anos 80, quando começaram as discussôes e o desenvolvimento das sementes geneticamente modificadas com o objetivo de aumentar a produçáo surgiu um grande problema no que se refere ao registro das patentes pelas empresas, e para isso foram criados os acordos de propriedade intelectual, citados anteriormente, os quais cediam uma série de direitos a empresas como Monsanto, Dow e Bayer (DESMARAIS, 2013). Nesse contexto, a FAO entrou na discussão com o objetivo de assegurar os direitos às grandes multinacionais, além de coordenar as políticas que norteariam a produção e o modo como esta se realizaria.

Por conta disso, movimentos sociais como a National Farmers Union -NFU, Union Paysanne, Border farm Workers Project tentaram chamar a atenção da FAO para que fosse levado em consideração, também, o direito dos agricultores, já que estes estavam sendo prejudicados por encontrar dificuldades de se inserir no mercado, devido à competitividade, já que a agricultura passou a ser neoliberalizada e boa parte da produçáo estava nas mãos de grandes multinacionais. Para tentar assegurar o direito dos agricultores, a Via Campesina criou a Campanha de Sementes, para que fossem respeitados os direitos dos agricultores, e que náo fosse promovido o uso racional das sementes geneticamente modificadas, além de procurar o respeito e direito de produção agrícola para as famílias (DESMARAIS, 2013).

Diante do exposto, observamos que a Via Campesina procura lutar pela soberania alimentar e para que seja valorizada a diversidade da produção no campo, no intuito de que se alcance uma segurança alimentar sem dependência entre os países, evitando que o fornecimento de comida sirva apenas aos propósitos da via de projeção de poder do sistema capitalista. Para isso, na realização da sua campanha de sementes pôde-se observar a mobilização para que os recursos fitogenéticos fossem acessíveis para a população camponesa, o que já seria um contraponto em relação à $F A O$, já que esta procura se preocupar com o direito das grandes empresas de produzirem seu conhecimento sobre sementes e, também, procura manter as políticas neoliberais da globalização, com vistas ao aumento da produção (DESMARAIS, 2013). 
Na I Conferência Mundial de Alimentação, organizada pela FAO, a Via Campesina foi alvo de preconceito, visto que as grandes autoridades presentes nas negociaçóes náo conseguiam enxergar o modelo descentralizado deste movimento social, formado basicamente por outras organizaçôes nacionais de camponeses, sendo uma representatividade da voz efetiva dessas.

O que fez com que o conceito de Soberania Alimentar ganhasse força foi singularmente o fato de que a soberania é um princípio regulador do Direito Internacional, e o documento sobre o direito de produzir redigido pela Via Campesina, na I Conferência Mundial de Alimentação tinha como um dos focos de sua agenda apresentar um código de conduta sobre o direito à alimentação. Esse documento, além deste direito, versava também sobre o controle do que era produzido, com restriçóes a importaçóes maciças que viessem a atrapalhar a produção agrária e o comércio agrário, no que diz respeito às pequenas famílias, e buscava tentar alcançar a consecução da Segurança Alimentar.

Em virtude dos resultados positivos, visto que a Via Campesina havia conseguido representar os camponeses com uma articulação internacional, a FAO a credenciou para representar a voz camponesa nas reunióes que sucederiam. Dessa maneira, os conceitos de Segurança e Soberania Alimentar fizeram parte de diferentes contextos das discussóes ocorridas, tanto que, posteriormente, ocorreu a reforma do Comitê de Segurança Alimentar para discutir a importância de um controle sobre os avanços da Segurança Alimentar pelo mundo. A Via Campesina, desde entáo, vem se tornando um mecanismo da sociedade civil e consegue ter representatividade nas cúpulas da FAO. Tal Movimento ainda tem conseguido modificar as agendas da referida Organizaçáo, tendo em vista que tem levado a segurança e a soberania alimentar gradativamente para a agenda das conferências organizadas pela Organização supracitada, fazendo com que os camponeses ganhem mais visibilidade (CAMARGO, 2013).

A Via Campesina, em 21 de março de 2014, organizou uma carta com 120 organizaçóes para o Dia Mundial das Florestas da ONU, com o objetivo de demandar da FAO uma mudança em suas definiçóes de floresta, sobretudo, com relação às comunidades que dependem desta, com vistas a regular a ocupação e exploração dos recursos naturais. No mesmo ano, a Via Campesina participou no mês de outubro, nos dias 18 e 19, de um Simpósio Internacional de Agroecologia, sediado em Roma, com o objetivo de dar mais notoriedade aos métodos de produçáo camponeses (DESMARAIS, 2013). 
A proposição agroecológica ${ }^{12}$ surgiu (e ainda se apresenta) como aspiração geral a outra forma de desenvolvimento. De acordo com Almeida (1998, p. 5):

A agroecologia tem se apoiado no uso potencial da diversidade social e dos sistemas agrícolas, especialmente daqueles que os agentes reconhecem como estando o mais próximo dos "modelos" camponês e indígena. [...] São as açôes sociopolíticas que podem contribuir para uma maior estabilidade e sustentabilidade dos agroecossistemas.

Em 2013, foi firmado um acordo entre a Via Campesina e a FAO para cooperação entre as duas organizaçóes com o objetivo de traçar metas comuns para melhor distribuição de terras, agricultura sustentável e segurança alimentar. Tornou-se importante a assinatura desse tratado, uma vez que a FAO reconheceu o papel da Via Campesina como representante da sociedade civil, principalmente, porque houve o reconhecimento de que este é o maior Movimento de pequenos agricultores do mundo (FAO, 2013).

\section{A OMC e a Via Campesina}

Enquanto a Via Campesina se configura como um movimento que procura diminuir a influência da OMC sobre a agricultura, ou até mesmo sua extinção nos assuntos agropecuários, a OMC é a principal organização responsável pela regulamentação de políticas com o objetivo de disseminar as práticas neoliberais, tanto para a economia dos Estados nas cidades quanto no campo, visto que suas políticas terão impactos fortes sobre a vida das famílias de camponeses (DESMARAIS, 2013).

A OMC surgiu em $1^{\circ}$ de janeiro de 1995 e, desde então, uma das lutas da Via Campesina é deixar que as políticas relativas à agricultura se configurem como competência da ONU e não mais da OMC. Isto porque, a OMC é um órgão de negociação formado por Estados, é muito fechada à sociedade civil, deste modo, a Via Campesina a enxerga como antidemocrática. Outro fator é que grande parte das políticas e agendas da organização supracitada é destinada a discussóes de medidas em benefício

12 Ver Almeida (1998); Altieri 1998), dentre outros autores. 
do agronegócio, como sementes transgênicas, diminuição ou extinção de taxas e impostos, medidas essas com o objetivo de integrar a agricultura no mercado internacional, facilitando a formação de monopólio empresarial da produção agropecuária (NIEMEYER, 2007).

Um dos pontos que merecem atenção a respeito da relação entre a Via Campesina e a OMC é que ao contrário da impressão que possa parecer, a Via Campesina não é contra a comercialização na agricultura. $\mathrm{O}$ que se observa é que este Movimento se contrapóe às medidas da OMC que deixam os camponeses sem possibilidade de vender seus produtos porque a economia local foi dominada pela produção em larga escala de transnacionais. Dessa forma, salientamos que a Via Campesina é comprometida com uma visão de mercado agrícola direcionado aos direitos humanos, ao contrário da OMC, que tem suas abordagens guiadas para o mercado, baseando-se, sobretudo, no lucro e no sucesso do sistema neoliberal.

Em junho de 2015, a Via Campesina uniu todos os seus representantes em um protesto contra as negociaçóes do Acordo Transpacífico, devido ao fato de que na regiáo da Ásia existe uma quantidade muito grande de pequenos camponeses e, de acordo com a Via Campesina, as medidas neoliberais elaboradas por este tipo de negociação têm forte impacto negativo sobre a produção agrícola:

Furthermore, the TPP is not simply an agreement about trade. Its provisions infringe upon the national sovereignty of the countries concerned, subjecting their citizens to rules that are dictated by the transnational corporations and leading to a deterioration in living conditions for the great majority - especially for family farmers, workers, and small business owners. By strengthening the intellectual property rights of pharmaceutical companies, the agreement will deprive poor people of prescription drugs [...]13 (VIA CAMPESINA, 2015).

13 "Além disso, o TPP não é simplesmente um acordo sobre o comércio. As suas disposiçóes infringem a soberania nacional dos países em causa, sujeitando os seus cidadãos com as regras que são ditadas pelas corporaçóes transnacionais e que conduzem a uma deterioração das condiçóes de vida para a grande maioria - especialmente para os agricultores familiares, trabalhadores e pequenos empresários. Ao reforçar os direitos de propriedade intelectual das empresas farmacêuticas, o acordo vai privar os pobres de medicamentos [...].” (Tradução nossa). 
Os acordos e as conduçóes políticas da OMC, como podem ser observados, prejudicam a soberania alimentar, principalmente sobre os países mais pobres, que têm como maioria as famílias camponesas. Através disso, pode-se perceber que ao buscar defender os interesses dos trabalhadores, a Via Campesina tenta ir de encontro à OMC e suas decisóes com relação à agricultura e à produção local.

\section{Consideraçóes finais}

De acordo com as leituras realizadas para a realização das reflexôes aqui presentes, concluímos que a Via Campesina tem se empenhado em lutas pelo globo com o objetivo de dar vozes aos camponeses que se tornaram sufocadas pelas políticas neoliberais. Além disso, tem contribuído para a conscientização da sociedade civil em outras questóes, como a exploração irracional de recursos naturais e a utilização maciça de fertilizantes químicos e de seres vivos transgênicos. O Movimento em foco trouxe, também, a noção da reforma agrária como uma questão de acesso democrático à terra, e da alimentação como um direito humano.

Por fim, observa-se que um dos caminhos mais importantes para se alcançar a igualdade, seja social, ou de gênero, é a partir do momento que se dá mais voz aos grupos oprimidos, e que estes tenham capacidade de se inserir no contexto das lutas com sua voz respeitada. Percebemos ainda que a partir do momento em que os países passaram a adotar as medidas sugeridas pela FAO, ratificando seus tratados; os pequenos agricultores e as mulheres conseguiram impactar a sociedade em seus respectivos países, seja no formato da proteção comercial, no caso dos pequenos agricultores, seja em políticas de inclusão feminina, tratando-se de inclusão de gênero.

\section{Referências}

ALTIERI, Miguel et al. O papel da biodiversidade no manejo de pragas. Ribeirão Preto: Holos, 2001.

ALMEIDA, Jalcione. Tecnologias agrícolas alternativas: nascimento de um novo paradigma? Ensaios FEE, Porto Alegre, v. 19, n. 2, p. 116-131, 1998. 
BRASIL. Constituição (1998). Constituição da República Federativa do Brasil: promulgada em 5 de outubro de 1998: atualizada até a Emenda Constitucional $\mathrm{n}^{\circ}$ 20, de 15-12-1998.

BRASIL. Lei n. ${ }^{\circ}$ 8.078, de 11 de setembro de 1990. Dispóe sobre a proteção do consumidor e dá outras providências. Diário Oficial de 12 de setembro de 1990. Brasília, 1990.

BRASIL. Lei de Segurança Alimentar e Nutricional - LOSAN. Lei n.o 11.346, de 15 de setembro de 2006. Cria o Sistema Nacional de segurança Alimentar e Nutricional - SISAN. Diário Oficial [da] República Federativa do Brasil. Poder Executivo. Brasília, DF, Seção 1, p. 1, 18 set. 2006.

BRITO, F.E.M O admirável mundo sombrio anunciado pela Monsanto: $\mathrm{O}$ Olho da História. Salvador (BA), julho de 2009. Disponível em: <http:// oolhodahistoria.org/n12/artigos/francisco.pdf >. Acesso em: 19 ago. 2015

\section{CAMARGO, Adriane de Sousa. Globalizaçáo e Hegemonia nas Relaçóes}

Internacionais: $\mathrm{O}$ caso da Via Campesina sob uma perspectiva gramsciana. 2013. 116 f. Dissertação do Curso de Relaçôes Internacionais. Instituto de Relações Internacionais, São Paulo, 2013.

DESMARAIS, Annette Aurélie. La Via Campesina: Globalization and the Power of peasants. Fernwood Publishing: Halifax, 2007.

. A Via Campesina: a globalização e o poder do campesinato. Tradução Carlos Alberto Silveira Netto Soares. São Paulo: Cultura Acadêmica; Expressão Popular, 2013. (Vozes do Campo)

FAO. Direito à Alimentaçáo e Segurança Alimentar e Nutricional nos Países da CPLP: Diagnóstico de Base. Roma. 2013. Disponível em: <http://www.fao. org/docrep/018/i3348p/i3348p.pdf>. Acesso em: 15 ago. 2015.

\section{. Construçáo do Sistema e da Política Nacional de Segurança}

Alimentar e Nutricional: a experiência brasileira. Brasília. 2009. Disponível em: $<$ https://www.fao.org.br/download/Seguranca_Alimentar_Portugues.pdf >. Acesso em: 23 ago. 2015.

Food and Agriculture Organization of the United Nations, FAO will cooperate with La Via Campesina, the largest movement of small-scale food producers in the world. Disponível em: <http://www.fao.org/news/story/en/ item/201824/icode/>. Acesso em: 22 ago. 2015.

FERNANDES, Bernardo Mançano. A questão agrária, pesquisa e MST. São Paulo: Cortez, 1996. 
GRZYBOWSKI, Cândido. Caminhos e descaminhos dos movimentos sociais no campo. 3. ed. Petrópolis, RJ: Vozes, 1991.

HOROCHOVSKI, Rodrigo Rossi. Empoderamento: definições e aplicaçôes. Encontro Anual da Associação de Pós-Graduação e Pesquisa em Ciências Sociais (ANPOCS), 30., 2006, Caxambu. Anais... Minas Gerais, 2006.

LAMARCHE, H. (Coord.). Agricultura familiar: comparação internacional. Tradução de Ângela M. N. Tijiwa. Campinas: Unicamp, 1993. (Coleção Repertórios)

La Via Campesina. Secretariado (Org.). Annual Report 2014. ZIMBABWE, Harare: La Via Campesina, 2015. 30 p. Disponível em: <http://viacampesina.org/ en/images/stories/pdf/EN_Annual_Report_2014_web.pdf >. Acesso em: 20 ago. 2015 .

MALUF, Renato S.; MENEZES, Francisco; MARQUES, Susana Bleil. Caderno 'Segurança Alimentar'. Rio de Janeiro: UFRRJ, 2007. 52 p. Disponível em: <http://ieham.org/html/docs/Caderno_Segurança_Alimentar.pdf $>$. Acesso em: 20 ago. 2015.

MARX, K. O Capital: crítica da economia política. 20. ed. Rio de Janeiro: Civilização Brasileira, 2002. (Livro 1, 2 v)

MARX, K.; ENGELS, F. A ideologia alemã. Tradução de Frank Müller. São Paulo: Martin Claret, 2005.

MARTINS, José de Souza. Reforma Agrária: o impossível diálogo sobre a História possível. Tempo Social [on-line], v. 11, n. 2, p. 97-128, 1999.

MEDEIROS, L. S. de. História dos movimentos sociais no campo. Rio de Janeiro: Fase, 1989.

NIEMEYER, Carolina Burle de. Via Campesina: uma análise sobre sua gênese e processo de consolidação. Raízes, Campina Grande, v. 26, n. 1, p. 59-70, jan., 2007.

OLIVEIRA, Isabella Petini de; SANTOS, Nivaldo dos. Acordos internacionais sobre propriedade intelectual e sua internalizaçáo no ordenamento jurídico brasileiro. 2012. Disponível em: <http://www.sbpcnet.org.br/livro/63ra/ conpeex/pibic/trabalhos/ISABELLA.PDF>. Acesso em: 25 ago. 2015.

OLIVEIRA, José Adilson de. O que significa agronegócio? 2010. Disponível em: <http://www.seea.org.br/artigojoseadilson2.php>. Acesso em: 5 set. 2015.

RIBEIRO, M. Movimento camponês, trabalho e educação: liberdade, autonomia e emancipação. São Paulo: Expressão Popular, 2010. 
SANTOS, Arlete Ramos dos. Ocupar, resistir e produzir também na educação. O MST e a burocracia estatal: negação e consenso. 2013. Tese (Doutorado em Educação), Faculdade de Educação, Universidade Federal de Minas Gerais, 2013.

SOUZA, Roberto Castelo Branco Coelho de. Trips na Organização Mundial da Propriedade Intelectual - OMPI. Economia Política Internacional: Análise Estratégica. Genebra, v. 1, n. 5, p. 27-31, abr., 2005.

STÉDILE, João Pedro (Org.). A questão agrária no Brasil: o debate tradicional - 1500-1600. São Paulo: Expressão Popular, 2005.

VIA CAMPESINA. Both sides of the Pacific: Via Campesina oppose TPP. Disponível em: <https://viacampesina.org/en/index.php/actions-and-eventsmainmenu-26/10-years-of-wto-is-enough-mainmenu-35/1828-both-sides-of-thepacific-via-campesina-members-oppose-tpp>. Acesso em: 14 maio 2016.

VIEIRA, Flávia Braga. Via Campesina: um projeto contra-hegemônico? Simpósio Lutas Sociais na América Latina, 3, 2011.

. Via Campesina: um projeto contra-hegemônico? Anais..., 3, 2011, Disponível em: <http://www.uel.br/grupo pesquisa/gepal/terceirosimposio/ flaviabraga.pdf>. Acesso em: 15 ago. 2015. 


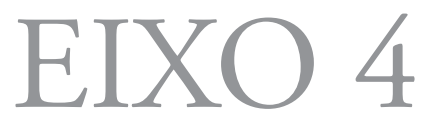

Educação em espaços não escolares 


\title{
A EDUCAÇÃO NAS PRISÓES COMO TÉCNICA DE CONTROLE DO CARCERÁRIO: ALGUMAS CONSIDERAÇÓES
}

\author{
Fábio Mansano de Mello ${ }^{1}$ \\ Ana Elizabeth Santos Alves ${ }^{2}$
}

\section{Introduçáo}

A proposta do referido trabalho é a de abordar a importância e a eficácia da educação escolar no sistema prisional, à luz das reflexóes de Foucault presentes em "Vigiar e punir"; a perspectiva de tornar um corpo politicamente dócil e economicamente útil perpassa a funcionalidade das instituiçóes totais e austeras e se cristalizam nos projetos de certificação escolar presentes nos presídios brasileiros.

Na primeira parte do texto, versamos sobre os três elementos apontados por Michel Foucault que fundamentam a perspectiva da reabilitação dos indivíduos por meio do encarceramento: o isolamento, o trabalho e a modulação da pena. Essas práticas constroem um saber técnico-científico que se resume na palavra disciplina. A manutenção dos corpos dóceis se atrela a um conjunto de fatores que constroem a mecânica da submissão, centrada na distribuição dos espaços, no controle das atividades, na potencialização do tempo dos indivíduos e na chamada composição das forças.

$\mathrm{Na}$ segunda parte, discutimos a presença e a importância da educaçáo escolar no cotidiano prisional, apresentando algumas de suas características, suas potencialidades e limites. Finalmente, fechamos o trabalho com algumas reflexóes acerca da funcionalidade da escola no presídio, bem como sua atividade disciplinadora no interior dessa instituição.

1 Professor do Departamento de Ciências Humanas e Letras, da Universidade Estadual do Sudoeste da Bahia (UESB), Campus de Jequié-BA. E-mail: < fmmello@yahoo.com.br>.

2 Professora do Departamento de Filosofia e Ciências Humanas, da Universidade Estadual do Sudoeste da Bahia (UESB), Campus de Vitória da Conquista-BA. E-mail: <ana_alves183@ hotmail.com>. 


\section{As dimensóes da prisáo e suas formas de controle}

Muitas questóes já foram levantadas sobre a estrutura e o funcionamento das prisôes, instituiçóes obscuras cercadas de histórias e lendas que povoam o imaginário das pessoas há séculos; trataremos neste texto da amplitude das técnicas de controle sobre o corpo do sentenciado que ultrapassa em muito o aspecto físico dos mesmos, pois pretende se alojar em última instância na mente do sujeito, influenciando decisivamente no seu comportamento. Na quarta parte do livro "Vigiar e punir" (1987), Foucault apresenta as características e a funcionalidade dessas "instituições completas e austeras", que fundamentam nossas primeiras reflexôes.

Se a prisão tem por finalidade transformar, recuperar, regenerar os indivíduos, o elemento funcionalidade é posto em cheque pelo filósofo quando afirma que conhecendo seus inconvenientes, "sabe-se que é perigosa quando não inútil. E, entretanto, não 'vemos' o que por em seu lugar" (FOUCAULT, 1987, p. 208). A princípio temos esse espaço estatal responsável pela segregaçáo do indivíduo que atenta à ordem social, retirando-lhe um valor marcante na sociedade moderna: sua liberdade; ao pagar sua dívida, o condenado está abrindo mão do seu tempo livre para refletir sobre sua condição e a se submeter a um conjunto de regras e normas cujo escopo é tornar seu corpo economicamente útil e politicamente dócil. Para se alcançar esses objetivos, a instituição total ${ }^{3}$ não traz a privação da liberdade e depois aplica as medidas correcionais. Foucault nos apresenta os indícios que esses dois papéis são realizados simultaneamente; vejamos essa elucidativa passagem onde explicita o modus operandis das casas correcionais:

A prisão deve ser um aparelho disciplinar exaustivo. Em vários sentidos: deve tomar a seu cargo todos os aspectos do indivíduo, seu treinamento físico, sua aptidáo para o trabalho, seu comportamento cotidiano, sua atitude moral, suas disposições; a prisão, muito mais que a escola, a oficina ou o exército, que implicam sempre numa certa especialização, é 'onidisciplinar'. Além disso, a prisão é sem exterior nem lacuna;

3 "Uma instituição total pode ser definida como um local de residência e trabalho onde um grande número de indivíduos com situação semelhante, separados da sociedade mais ampla por considerável período de tempo, leva uma vida fechada e formalmente administrada" (GOFFMAN, 1974, p. 11). 
não se interrompe, a não ser depois de terminada totalmente sua tarefa; sua ação sobre o indivíduo deve ser ininterrupta: disciplina incessante. Enfim, ela dá um poder quase total sobre os detentos; tem seus mecanismos internos de repressão e de castigo: disciplina despótica. Leva à mais forte intensidade todos os processos que encontramos nos outros dispositivos de disciplina (FOUCAULT, 1987, p. 211).

Quando essa máquina disciplinar entra em ação, ela dispóe de algumas estratégias para que a atividade deste reformatório obtenha os resultados desejados ${ }^{4}$. $\mathrm{O}$ autor destaca três elementos que se complementam, a saber: o isolamento, o trabalho e a normalização. Vejamos mais de perto esses aspectos, pois a educação escolar prisional contemporânea que abordaremos se apoiará nesses pilares para sua efetivação.

No que tange ao isolamento, Foucault demonstra que a individualização coercitiva é o primeiro passo da ação carcerária, da submissão total dos homens privados da liberdade em relação ao sistema reformador. Somam-se na contemporaneidade alguns elementos da despersonificação dos sentenciados, tais como a primazia da matrícula de ingresso em relação ao seu nome (ele passa a ser chamado pelo número) e a padronização dos uniformes dos mesmos. "O isolamento assegura o encontro do detento a sós com o poder que se exerce sobre ele" (FOUCAULT, 1987, p. 212). Mediante o isolamento do indivíduo em relaçáo "à rua" e aos outros encarcerados, o infrator é conduzido pelas mãos da solidão à reflexão sobre seus atos e ao arrependimento que dará indícios de sua recuperação; é a mudança de moralidade, a transformaçáo de sua consciência os alvos a serem atingidos pela aplicação da individualização coercitiva. Polêmica relevante e em certa medida atual levanta o filósofo francês acerca dos conflitos do isolamento: a orientação religiosa seria o fundamento da recuperação do indivíduo? Uma questão médica: até que ponto o isolamento não levaria ao enlouquecimento? Também problemas econômicos, uma vez que lida com os custos da manutenção do sistema e fatores administrativos e arquiteturais, que dizem respeito à melhor forma de controle e vigilância.

4 "A operação penitenciária, sua organização, procedimentos, normas, programas e atividades, configurados para proporcionar a reabilitação dos criminosos, culminam por convergir suas açôes para aprimorar a contençáo e o controle da massa encarcerada” (PORTUGUES, 2001, 358). 
O segundo ponto diz respeito ao trabalho; as atividades laborativas não são compreendidas nem como aditivas nem como corretivas no que tange sua finalidade: é uma necessidade muito mais pela regeneração do que pela possibilidade de um salário. Após apresentar o debate ocorrido na sociedade francesa no século XIX, acerca da remuneração dos presos bem como das condiçóes de trabalho nas prisóes em detrimento do trabalho assalariado na sociedade civil, Foucault afirma:

O trabalho penal não pode ser criticado pelo desemprego que provocaria: com sua parca extensão, seu fraco rendimento, ele não pode ter incidência geral sobre a economia. Não é como atividade de produção que ele é intrinsecamente útil, mas pelos efeitos que toma na mecânica humana. É um princípio de ordem e de regularidade; pelas exigências que lhe são próprias, veicula, de maneira insensível, as formas de um poder rigoroso; sujeita os corpos a movimentos regulares, exclui a agitação e a distraçáo, impóe uma hierarquia e uma vigilância que serão ainda mais bem aceitas, e penetrarâo ainda mais profundamente no comportamento dos condenados, por fazerem parte de sua lógica [...]FOUCAULT, 1987, p. 216).

Assim se dá a formação do homem-máquina, sujeito que através da rotina e disciplina do trabalho "transforma o prisioneiro violento, agitado, irrefletido em uma peça que desempenha seu papel com perfeita regularidade" (FOUCAULT, 1987, p. 216). Dessa forma, temos com o trabalho uma espécie de metamorfose - o ladrão se constitui num operário. Mas não operário no sentido estrito, e sim como o indivíduo transformado moralmente que receberá seu soldo; o salário aqui não visto como recompensa pela produção, e sim como ponto fundamental do condicionamento do encarcerado às regras da correção. Em seguida, Foucault questionando sobre a utilidade do trabalho penal, afirma que não se trata da obtenção nem de lucro sequer de desenvolvimento de habilidades; o fato diz respeito exclusivamente "a constituição de uma relação de poder, de uma forma econômica vazia, de um esquema da submissáo individual e de seu ajustamento a um aparelho de produçáo" (FOUCAULT, 1987, p. 217).

A terceira estratégia do aparelho carcerário é a prisão como modulação da pena: "um aparelho que, através da execução da sentença de que está encarregado, teria o direito de retomar, pelo menos em parte, seu 
princípio" (FOUCAULT, 1987, p. 217). Nesse sentido, é percebida a duração do castigo: quantificar a pena, mas não como medida da gravidade do crime, mas se ajustar no tempo hábil da regeneração do apenado. A pena individualizada não pode ser levada em consideração apenas se referindo ao indivíduo infrator, mas sim levando em conta a amplitude e a autonomia de se efetivar a partir do indivíduo punido. Sobre essa espécie de caráter autônomo do carcerário, Foucault elucida a modulação das penas da seguinte forma:

Se o princípio da pena é sem dúvida uma decisão da justiça, sua gestáo, sua qualidade e seus rigores devem pertencer a um mecanismo autônomo que controla os efeitos da punição no próprio interior do aparelho que os produz. Todo um regime de puniçóes e de recompensas que não é simplesmente uma maneira de fazer respeitar o regulamento da prisão, mas de tornar efetiva a ação da prisão sobre os detentos (FOUCAULT, 1987, p. 219).

Nessa perspectiva de transformação do indivíduo, os funcionários mais próximos dos detentos podem avaliar sua evolução e possível progressão de regime; tal qual aponta Foucault, diretor, sacerdote e professor sáo mais capazes de aplicar a funçáo corretiva que os detentores do poder penal. Todos esses fenômenos indicam que as dimensóes da prisão ultrapassam suas muralhas, pois envolvem um denso aparato de correção que parte da sociedade civil ao tempo que a aparta dos estabelecimentos penais.

Ressaltamos, na obra do pensador, um dos fundamentos do êxito náo só das casas correcionais, mas de inúmeras instituiçôes, como o exército, a escola, a fábrica, o convento etc. Trata-se da disciplina. A manutenção dos corpos dóceis se atrela a um conjunto de fatores que constroem a mecânica da submissão, centrada na distribuição dos espaços, no controle das atividades, na potencialização do tempo dos indivíduos e na chamada composição das forças.

A disciplina aumenta as forças do corpo (em termos econômicos de utilidade) e diminui essas mesmas forças (em termos políticos de obediência). Em uma palavra: ela dissocia o poder do corpo; faz dele por um lado uma 'aptidáo', uma 'capacidade' que ela procura aumentar; e inverte por outro lado a energia, a potência que poderia resultar disso, e faz dela 
uma relação de sujeição estrita. Se a exploração econômica separa a força e o produto do trabalho, digamos que a coerção disciplinar estabelece no corpo o elo coercitivo entre uma aptidão aumentada e uma dominação acentuada (FOUCAULT, 1987, p. 127).

Passemos agora à análise de como a educação escolar no sistema prisional corrobora com essas perspectivas apontadas por Foucault e, mais que isso, o controle do carcerário ganha novos contornos com essa modalidade de vigilância.

\section{A educaçáo no sistema prisional}

Quando falamos em educação na prisão, sobre a existência de escolarização para detentos, a primeira reaçáo das pessoas que não conhecem a realidade prisional é de espanto: "E preso ainda estuda!". Compreende-se essa afirmativa a partir de duas premissas: primeiro, a imagem da consciência coletiva que traz o sentenciado como subumano que precisa sofrer nas casas correcionais e, em segundo lugar, a visão da escola como privilégio para o transgressor. Nesse cenário, vamos refletir sobre a amplitude e a funcionalidade da educação escolar no sistema prisional, tendo por base fundamentalmente a realidade do estado de Sáo Paulo, local onde esse tipo de educação está consolidado há algumas décadas. Voltando à cena do espanto inicial, quem são os "estudantes" que ocupam as "celas" de aula?

Os presos fazem parte da população dos empobrecidos, produzidos por modelos econômicos excludentes e privados de seus direitos fundamentais de vida. Ideologicamente, como os "pobres", são jogados em um conflito entre as necessidades básicas vitais e os centros de poder e decisão que as negam. São, com certeza, produtos da segregação e do desajuste social, da miséria e das drogas, do egoísmo e da perda de valores humanitários. Pela condição de presos, seus lugares na pirâmide social são reduzidos à categoria de "marginais", "bandidos", duplamente excluídos, massacrados, odiados (ONOFRE, 2007, p. 12).

O sociólogo Loic Wacquant (2001) traz elementos para compreensão das chamadas prisóes da miséria. Segundo ele, num sugestivo estudo sobre 
o sistema prisional europeu e norte-americano, mas que entendemos ser perfeitamente aplicado ao caso brasileiro, trata das relaçóes das penas de reclusão com a condição social do sentenciado:

No momento de sua institucionalização na América de meados do século XIX, 'a reclusão era antes de tudo um método visando o controle das populaçōes desviantes dependentes' e os detentos, principalmente pobres e imigrantes europeus recém-chegados no novo mundo. Em nossos dias, o aparelho carcerário americano desempenha um papel análogo com respeito aos grupos que se tornam supérfluos ou incongruentes pela dupla reestruturação da relação social e da caridade do estado: as fraçóes decadentes da classe operária e os negros pobres das cidades (WACQUANT, 2001, p. 96).

De uma maneira geral, a população carcerária é formada pelas parcelas precarizadas do proletariado, e essa decorrência não só implica nas questóes da escolarização formal como também na própria acumulação capitalista ${ }^{5}$.

No que tange à escola na prisão, algumas questôes são norteadoras para o entendimento de sua existência num local como o presídio: como ela surge? O que ela significa para o apenado? Qual seu papel na chamada "ressocialização" dos indivíduos?

Segundo a Lei de Execução Penal, n 7.210, de 11 de julho de 1984, o Artigo 10 orienta que: "a assistência ao preso e ao internado é dever do Estado, objetivando prevenir o crime e orientar o retorno à convivência em sociedade". O Artigo 11 define que a assistência será: I - material; II - à saúde; III - jurídica; IV - educacional; V - social; VI - religiosa. Vejamos as características da assistência educacional:

Art. 17. A assistência educacional compreenderá a instrução escolar e a formação profissional do preso e do internado.

Art. 18. O ensino de $1^{\circ}$ grau será obrigatório, integrando-se no sistema escolar da Unidade Federativa.

Art. 18-A. O ensino médio, regular ou supletivo, com formação

5 "A multa é burguesa e pequena burguesa a prisão com sursis é popular, o regime fechado é subproletário: a célebre forma de Bruno Aubusson de Cavarlay, resumindo o funcionamento da Justiça na França entre 1952 e 1978 é ainda mais verdadeira na era do desemprego em massa e do acirramento das desigualdades sociais" (WACQUANT, 2001, p. 107). 
geral ou educação profissional de nível médio, será implantado nos presídios, em obediência ao preceito constitucional de sua universalização. (Incluído pela Lei no 13.163, de 2015)

$\$ 1^{\circ} \mathrm{O}$ ensino ministrado aos presos e presas integrar-se-á ao sistema estadual e municipal de ensino e será mantido, administrativa e financeiramente, com o apoio da União, não só com os recursos destinados à educação, mas pelo sistema estadual de justiça ou administração penitenciária. (Incluído pela Lei no 13.163 , de 2015) $\$ 2^{\circ}$ Os sistemas de ensino oferecerão aos presos e às presas cursos supletivos de educação de jovens e adultos. (Incluído pela Lei $n^{\circ} 13.163$, de 2015)

$\$ 3^{\circ}$ A União, os Estados, os Municípios e o Distrito Federal incluirão em seus programas de educação à distância e de utilização de novas tecnologias de ensino, o atendimento aos presos e às presas. (Incluído pela Lei no 13.163, de 2015)

Art. 19. O ensino profissional será ministrado em nível de iniciação ou de aperfeiçoamento técnico.

Parágrafo único. A mulher condenada terá ensino profissional adequado à sua condição.

Art. 20. As atividades educacionais podem ser objeto de convênio com entidades públicas ou particulares, que instalem escolas ou ofereçam cursos especializados.

Art. 21. Em atendimento às condiçóes locais, dotar-se-á cada estabelecimento de uma biblioteca, para uso de todas as categorias de reclusos, provida de livros instrutivos, recreativos e didáticos. Art. 21-A. O censo penitenciário deverá apurar: (Incluído pela Lei no 13.163, de 2015)

I - o nível de escolaridade dos presos e das presas; (Incluído pela Lei no 13.163, de 2015)

II - a existência de cursos nos níveis fundamental e médio e o número de presos e presas atendidos; (Incluído pela Lei no 13.163, de 2015)

III - a implementação de cursos profissionais em nível de iniciação ou aperfeiçoamento técnico e o número de presos e presas atendidos; (Incluído pela Lei $\mathrm{n}^{\circ} 13.163$, de 2015)

IV - a existência de bibliotecas e as condiçóes de seu acervo; (Incluído pela Lei no 13.163 , de 2015)

$\mathrm{V}$ - outros dados relevantes para o aprimoramento educacional de presos e presas. (Incluído pela Lei no 13.163, de 2015)

Posta a questão legal, o que leva o indivíduo a se matricular na escola? A maioria desses homens já foi excluída do processo de escolarização 
quando em liberdade, por que retornar a ele num momento onde a segurança e a sobrevivência falam mais alto? Inúmeras são as respostas, e a própria "sobrevivência" é uma delas:

[...] a frequência às atividades escolares justifica desde o desejo de aprender, de buscar passatempo, até a busca de um parecer positivo nos exames criminológicos que possibilite a sua saída da prisão. Mesmo não tendo consciência da função histórica da escola e de seu papel na construção da cidadania, seu objetivo, ao frequentá-la, é "acatar as regras da casa", visando a buscar todas as alternativas possíveis para abreviar sua estada na unidade prisional ou a conseguir benefícios e ser encaminhado para os presídios semi-abertos (ONOFRE, 2007, p. 19).

Vários são os argumentos utilizados pelos detentos para explicitar a importância da escola; todos eles demonstram tanto perspectivas de ganhos pessoais no que tange ao conhecimento adquirido e, também, estratégias de defesa e de progressão de regime. Uma das falas mais recorrentes é que a escola ocupa a mente, ajuda a passar o tempo num local onde o isolamento e a solidão imperam; além disso, entram em contato com o mundo externo, com conteúdos mediados pelo "professor da rua" (em algumas unidades prisionais existe o monitor preso, detento escolhido e capacitado para conduzir o processo educativo escolar) que os deixa informados sobre o que acontece para além dos muros. Não deixa de ser relevante o fato de que a escola na unidade prisional é um espaço que recebe presos de vários "raios", nome dado aos pavilhóes onde se alojam os detentos; dessa forma, podem dialogar com outros sentenciados que, se não fosse pela condição de presos-estudantes, não teriam condição de fazê-lo. Onofre aponta ainda que grande parte dos apenados busca a escola para sanar uma carência que carregam há tempos, ou seja, possibilidade de aprenderem a ler e a escrever; o analfabetismo deixa suas marcas no indivíduo e na prisão são ainda mais acentuadas:

Ler e escrever na prisão é fundamental, pois não ter essas qualidades implica dependência do companheiro. É com esses conhecimentos que os detentos podem escrever e ler cartas, bilhetes e acompanhar o desenrolar de seus processos criminais, e isso significa ter mais liberdade, autonomia e privacidade, até porque quem não sabe, pede, e quem pede, deve. 
Na prisão até favor é dívida, e dívida é risco de vida (ONOFRE, 2007, p. 21).

Portugues (2001) analisa as possibilidades de se desenvolver atividades socioeducativas num espaço tão hostil e limitado como os presídios. No que tange à escola, aponta a existência, de um lado, das rígidas normas, aparato de vigilância e procedimentos de segurança, e de outro um espaço educativo que pode proporcionar "a autonomia, a crítica, a criatividade, a reflexão, a sensibilidade, a participação, o diálogo, o estabelecimento de vínculos afetivos, a troca de experiências, a pesquisa, o respeito e a tolerância” (PORTUGUES, p. 360).

$\mathrm{O}$ autor explica que a sequência das aulas é frequentemente comprometida tanto pelo estabelecimento prisional quanto pelas ausências dos sentenciados. Da parte da prisão, as aulas são canceladas por conta de: a) blitz, que são as revistas gerais dadas em todo o presídio, sem data determinada, aplicada pelos diretores de segurança; b) falta de funcionários no plantão, uma vez que todos os presos são revistados por eles antes de se dirigirem ao pavilhão escolar; c) dia do pecúlio, os sentenciados que trabalham não recebem dinheiro em espécie, eles passam uma lista de produtos à direção que os repassa mediante desconto na "folha de pagamento". Da parte dos sentenciados as justificativas de ausências às aulas mais frequente são: a) atendimentos de natureza jurídica, médica ou social; b) trabalho, muitos exercem atividades remuneradas (ainda que minimamente) e em determinados períodos do mês precisam aumentar a produção ${ }^{6}$; c) concorrência da escola com atividades esportivas, principalmente se tratando de campeonatos internos de futebol, já que nesses eventos ocorrem apostas e um acompanhamento de perto (PORTUGUES, 2001, p. 361-362).

Face ao exposto, quais as possibilidades efetivas de ressocialização do aluno-preso? Conforme a literatura consultada aponta, a reabilitação

6 Vale salientar a questão da remição da pena. Conforme o Artigo 126 da Lei de Execução Penal, a contagem do tempo para fins de remição será feita em razão de um dia de pena por três de trabalho (18 horas) realizado; isso significa que o sentenciado que trabalhar três dias terá um dia descontado de sua pena. Existem estados da federação que ampliaram a remição para a frequência escolar, entendendo que se trata de trabalho intelectual; nesses casos, a razão da remição é de nove dias de aula (18 horas) para um dia da pena. 
do indivíduo (embora reabilitar tenha inúmeros sentidos, principalmente na situação que estamos tratando) implica necessariamente na sua subordinação à disciplina e a sua própria anulação enquanto sujeito; sua adaptação ao sistema carcerário significa a mortificação do indivíduo. De outro lado, inegável é a funcionalidade da escola no espaço prisional, uma vez que possibilita ao encarcerado não só adquirir conhecimento formal e ter acesso à certificação, mas oportuniza diálogos sem censura que podem ampliar sua visão de mundo. Essas contradiçóes definem bem o espaço escolar nas unidades prisionais: esclarecer os sujeitos que estáo anulados pelo Estado.

\section{Consideraçóes finais}

No final deste trabalho, constatamos a vinculação entre a escola e o aparelho disciplinador da prisão no que tange a elaboração e constituição dos "corpos dóceis"; não poderia ser diferente. O carcerário utiliza regras rígidas na conduta dos indivíduos e a inserção do apenado no pavilhão escolar é mais uma peça dessa engrenagem cujo escopo é a devolução à sociedade de um sujeito recuperado, ressocializado e reabilitado. Mas o que esperar de uma empresa arcaica como a prisão, já que a própria sociedade com suas instituiçôes centradas num estado democrático de direito náo consegue socializar os indivíduos a contento? A prisão dos pobres reforça uma dupla exclusão, social e econômica, que o aparelho escolar reproduz em certa medida. Sem negar sua importância, a escola reforça a obediência às regras e normas impostas pelo carcerário.

\section{Referências}

BRASIL, Lei de Execuçáo Penal. Lei nº 7.210 de 11 de julho de 1984. Disponível em: <http://www.planalto.gov.br/ccivil_03/LEIS/L7210.htm>. Acesso em: 20 nov. 2015.

FOUCAULT, Michel. Vigiar e punir. Petrópolis: Vozes, 1987.

GOFFMAN, Erwin. Manicômios, prisóes e conventos. São Paulo: Editora Perspectiva, 1974. 
ONOFRE, Elenice Maria Cammarosano. Escola da prisão: espaço de construção da identidade do homem aprisionado? In: ONOFRE, Elenice Maria Cammarosano (Org.). Educaçáo escolar entre as grades. São Carlos: EDUFSCar, 2007.

PORTUGUES, Manoel Rodrigues. Educação de adultos presos. Revista Educação e Pesquisa, São Paulo, v. 27, n. 2, p. 355-374, jul./dez., 2001.

WACQUANT, Loic. As prisóes da miséria. Rio de Janeiro: Jorge Zahar Editores, 2001. 


\title{
FORMAR/AÇÓES PARA UMA IDENTIDADE DE EDUCADOR SOCIAL EM ESPAÇOS NÁO ESCOLARES
}

\author{
Arthur Vianna Ferreira ${ }^{1}$
}

\section{Introduçáo}

O educador social contemporâneo se apresenta como o sujeito que se coloca responsável pela organizaçáo dos trabalhos socioeducativos proporcionados por diversas instituiçóes sociais que buscam atender as distintas - e cada vez mais complexas - necessidades da população civil.

Esse educador surge no contexto educacional brasileiro com uma identidade socioprofissional alicerçada em três grandes bases: as demandas das camadas empobrecidas; uma formação específica que atenda, minimamente, as demandas suscitadas no seu campo de trabalho profissional; e a relaçáo construída por esse educador, tanto entre outros especialistas (equipe multidisciplinar) do mesmo campo de atuação socioeducacional quanto com os sujeitos empobrecidos com os quais atua diretamente.

$\mathrm{Na}$ história da educação, a figura do educador responsável pela formação dos empobrecidos sempre esteve associada à capacitação profissional dos educandos como forma de inclusão na sociedade brasileira.

Nos estudos de Venâncio (1999), a assistência oferecida aos pobres estava no trabalho realizado pelos educadores chamados 'mestres de oficios', responsáveis pela formação dos 'recolhidos' pela instituição. Um dos exemplos citados por Venâncio (1999, p. 151) era o da Santa Casa de Misericórdia do Rio de Janeiro e dos Aprendizes do Arsenal da Marinha no Século XIX segundo os quais "o ensino dos ofícios manuais cabia a mestres e contramestres, distribuídos em oficinas de tanoaria, carpintaria, serralheria, latoaria e espingardaria”.

1 Doutor em Educação: Psicologia da Educação pela PUCSP. Professor adjunto de Didática do Departamento de Educação (DEDU) da Faculdade de Formação de Professores da Universidade do Estado do Rio de Janeiro (UERJ/FFP) - Rio de Janeiro - RJ - Brasil. E-mail:<arthur.vf@gmail.com>; <arthur.ferreira@uerj.br>. 
A figura do 'mestre ou contramestre' como aqueles que se encarregavam pela educação dos empobrecidos do século XIX também aparece nos estudos de Marcilio (2006, p. 182) sobre a criança abandonada. Nestes, a autora relata a exploração da mão de obra sofrida por muitos órfãos pobres por parte dos 'mestres de oficios' que, ao iniciar os menores nas artes dos ofícios, exploravam os meninos sem a preocupaçáo de dar o devido treinamento para que pudessem produzir por si só as técnicas do ofício aprendido.

Khulmann Jr (2002, p. 486) aponta que as instituiçóes do início do século XX para os desamparados sociais deveriam organizar seu corpo de educadores para "[...] harmonizar a educação escolar e o ensino industrial ou profissional, de modo que os homens pudessem ganhar a vida pelo trabalho e as mulheres se habilitassem nos trabalhos domésticos e fossem capazes de gerir uma casa”.

Porém, outro ponto é adicionado, ao longo da história, ao trabalho do educador com os empobrecidos. Para além da utilização de uma educação suplementar - aos conteúdos escolares básicos - de caráter profissional que os incluísse no contexto social, se fazia necessário aos educadores que se preocupassem com a educação moral dos empobrecidos. Como nos diz Khulmann Jr (2002, p. 489), "se a preocupação com o conhecimento e com as condiçóes físicas das instituiçóes educacionais para os pobres pode ser secundarizada, a educaçáo moral torna-se o novo objeto de preocupação prioritário".

Esse novo aspecto, que surge como importante na prática do educador nas instituiçóes sociais destinadas aos empobrecidos do início do século XX, foi assinalado também por Moraes (2003, p. 265-266), em seus estudos sobre a qualificação profissional dos trabalhadores pobres em São Paulo, em 1930.

Nas escolas populares, além do ensino escolar básico (linguagem oral e escrita, cálculo, Geografia e História) e, também, de uma qualificação para a profissáo, a educaçáo era complementada por noçóes de moral e cívica, de acordo com os programas e métodos adotados pelo Anuário Estadual do Ensino de 1918, "visando ao controle, à moralização, ao ajustamento da população empobrecida às realizaçôes do governo republicano no plano estadual" (Ibidem, p. 266).

Assim sendo, a gênese que marca a característica do trabalho do educador em instituiçóes para camadas populares constitui-se numa açáo socioeducativa "triplo-inclusiva", que legitimava a permanência e aceitação deste grupo social empobrecido em relaçáo ao contexto social brasileiro. 
Esse trabalho era realizado em três frentes de trabalho socioeducativo: o de inclusão educacional, que compreendia a complementação da educação básica, capacitando o sujeito a se relacionar com os demais grupos, a partir do reforço da leitura e da escrita; o de inclusão profissional, relacionado com a aprendizagem de uma capacitação profissional como forma de inclusão no mercado de trabalho e geração de renda familiar; e o de inclusão relacional-moralista, que pretendia proporcionar aos pobres um conjunto de valores, significados, crenças e representaçóes partilhadas entre os demais grupos como organizadores da ordem e das relaçóes sociais.

Quadro 1 - Esquema da ação socioeducativa de características 'triplo-inclusiva’ organizado pelos educadores sociais no início do século XX

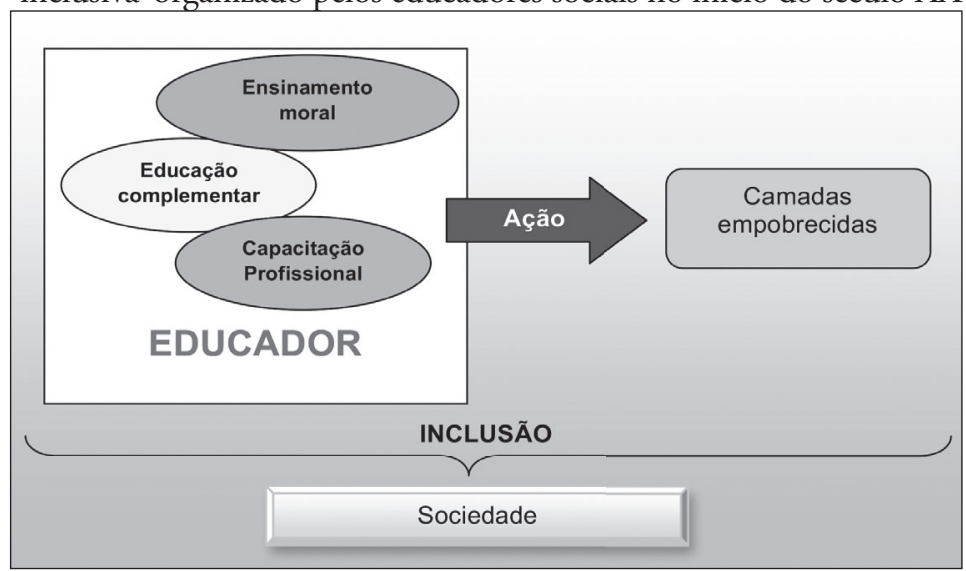

Fonte: Organizado pelo próprio autor.

Portanto, o educador das camadas populares deveria possuir essas três habilidades para exercer a sua prática educacional que buscava atender a ação socioeducativa 'triplo-inclusiva'. A sua prática institucional inclusiva vai marcando o caráter do seu trabalho social e compondo a sua figura como uma marca característica de sua 'profissionalidade' enquanto educador social.

Os conceitos pedagógicos de uma educação enraizados no contexto histórico brasileiro, difundidos a partir da década de 1970 - e tendo como um dos seus principais expoentes o educador Paulo Freire, na Pedagogia da Libertação, - acentuaram o caráter social e inclusivo do trabalho que os educadores das camadas empobrecidas iam realizando nos espaços de educação não formal. Duas mudanças aconteceram na estrutura do seu grupo profissional e que são fundamentais na constituição de seu grupo. 
Primeiro, a desobrigação de uma formação 'multi-especializada' do educador, ou seja, um educador que tenha obrigatoriamente que responder com sua formaçáo a todas as necessidades do grupo empobrecido. A partir deste momento, prioriza-se a pertença deste educador a um grupo de profissionais que tenha suas habilidades específicas, e um objetivo organizado por estratégias e práticas em comum, em favor das demandas e temáticas selecionadas pela população atendida.

Segundo, é que o trabalho de inclusão de caráter mais relacional, oferecido no começo pelo ensino de uma 'moral' oriunda da sociedade mantenedora das instituiçóes sociais, continua fazendo parte da constituição do educador social, porém com outra conotação. A preocupação com a moralidade foi trocada por uma crítica da realidade e uma consciência de sua participação ativa da sociedade que passa ser objeto de ensino do educador ao grupo de educandos.

Paulo Freire (2005) e seus conteúdos pedagógicos oriundos da 'pedagogia da libertaçáo' tiveram importante contribuição para as mudanças ocorridas neste grupo socioeducativo ao evocar aos encarregados pela educação das camadas empobrecidas a 'dialogicidade' no processo educativo.

O 'diálogo educativo' proposto por Freire acaba sendo um dos instrumentos mais utilizados nos espaços educacionais não formais pelos educadores sociais, uma vez que potencializa o despertar da realidade vivida pelo sujeito e seus contextos sociais como diz o próprio autor (ibidem, p. 95): “É um pensar que percebe a realidade como processo, que a capta em constante devenir e não como algo estático. Não se dicotomiza a si mesmo na ação. Banha-se permanentemente de temporalidade, cujos riscos não teme."

Em verdade, o processo de diálogo entre educador e educando proposto por Freire e utilizado de maneira constante pelo educador social acentua este trabalho inclusivo relacional que compóe a estrutura do educador social. Ele possibilita a abertura para uma confiança no processo de ensino-aprendizagem que dá ao educador a segurança de que seu trabalho, independente do estado socioeconômico em que se encontra o seu educando, poderá ser concretizado através da consciência ativa da participação do educando no meio social. Como o próprio Freire (2001, p. 297), "não há que considerar perdido o tempo do diálogo que, problematizando, critica e, criticando, insere o homem em sua realidade como verdadeiro sujeito de transformaçâo."

Como nos diz Zitkoski (2006, p. 27), sobre a dialogicidade da Pedagogia da Libertação de Freire: 
Ao definir a dialogicidade, a ação dialógica ou a ação cultural para a liberdade como um caminho de reconstrução da vida em sociedade, Freire está defendendo um projeto maior que se articula por meio de uma visão de sociedade igualitária, uma concepção de vida humana dialógica e dialética e uma proposta de educação radicalmente libertadora que, no conjunto, se harmonizam por meio da racionalidade dialógica. É uma racionalidade que busca construir a existência humana de modo crítico e criativo frente à realidade sociocultural que nos condiciona, desumaniza e coisifica.

Este diálogo educativo com o grupo empobrecido ajudará na organização dos conteúdos a serem utilizados em suas práticas educativas, marcando assim suas relaçôes interpessoais com os sujeitos e o seu reconhecimento pelo grupo como profissional da educação social. $\mathrm{O}$ trabalho inclusivo 'moral' abre espaço para a 'reflexão crítica' dos grupos tanto de educandos quanto de educadores, devendo ser a sua prática institucional educativa a intersecção entre ambos.

Para educador-educando, dialógico, problematizador, o conteúdo programático da educação não é uma doação ou uma imposição - um conjunto de informes a ser depositado nos educandos

Quadro 2 - Esquema da açáo socioeducativa de características 'dialógicas' organizado pelos educadores sociais a partir da década de 1970

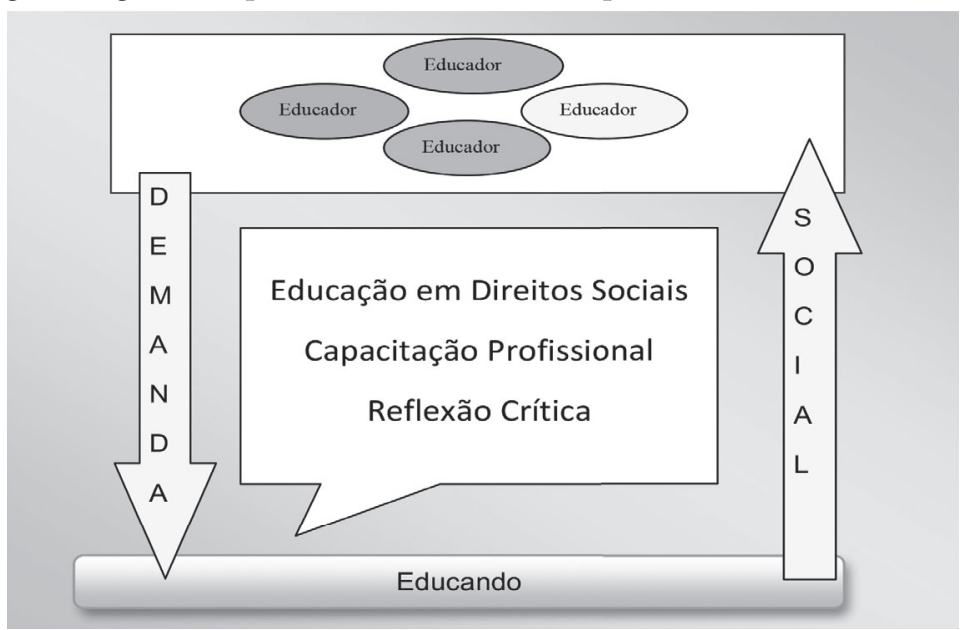

Fonte: Organizado pelo próprio autor. 
-, mas a devolução organizada, sistematizada e acrescentada ao povo daqueles elementos que este lhe entregou de forma desestruturada (FREIRE, 2005, p. 97).

O quadro anterior nos mostra a mudança do trabalho do educador social na atualidade. O educador social - antes detentor exclusivo da tríplice inclusão: educacional, profissional e moral - agora é um profissional chamado a trabalhar de forma multidisciplinar com outros especialistas, com o objetivo de atender às demandas sociais de seus educandos.

Além disso, o processo educativo dialógico se torna fundamental em dois aspectos de sua prática socioeducativa: primeiro, para a reflexão crítica da realidade do educando que, mais do que aceitar o seu estado de pobreza, critica-o e redimensiona os seus objetivos, para que se torne sujeito ativo de sua inclusão social, e, segundo, para a legitimação das relaçóes de alteridade vividas pelo educador social, que permite uma melhor organização do seu trabalho socioeducativo entre os seus pares e a população atendida.

\section{As açóes formativas do educador social no contexto brasileiro de espaços náo escolares}

A formação para educadores sociais ainda é algo complexo até os dias atuais, assim como a caracterização comum da atuação de seus profissionais. Autores da educaçáo social como Romans; Petrus; Trilla (2003) apontam as dificuldades de se traçar um perfil profissional dos educadores sociais que, no entanto, vai se tornando claro por meio da difusáo dos estudos sobre o tema, da especificação de suas tarefas feitas pelas administraçôes públicas, das contribuiçôes das associaçôes de educadores que trabalham no campo social e da reflexão que os próprios educadores fazem da sua prática.

Segundo os autores supracitados, as funçóes exercidas pelos educadores no meio externo e interno das instituiçôes proporcionam uma amplitude que, muitas vezes, dificulta a visualização de sua área de atuação. Por mais que o profissional tenha uma habilidade específica, ao entrar no grupo de educador social, ele precisa reorganizar a sua prática a partir de seu espaço de atuaçáo que é determinado pela instituição em seu rol de tarefas e de trabalhos a serem realizados. 
O trabalho do educador social requer definição, por parte de quem o contratou, de certas funções que nem sempre são vistas com clareza. A imprecisão das mesmas derivas das multiformes tarefas que o educador social desenvolve e que costumam repercurtir em seu nível de satisfação e possivelmente no serviço que se presta no próprio estabelecimento (ROMANS; PETRUS; TRILLA, 2003, p. 119).

Essa aparente falta de clareza da determinação da constituição essencial do educador social ocorre pela múltipla demanda de sua atuação e pelos próprios relacionamentos que ele vai construindo em seu campo de trabalho. Ou seja, o educador social, independente de sua formação universitária, teria que articular suas atividades, levando em consideração as desvantagens sociais em que se insere a instituição, a busca pela igualdade de oportunidades no contexto social para as necessidades dos grupos envolvidos, utilizando-se de políticas que auxiliem os desfavorecidos.

A complexidade suscitada pelas demandas existentes no campo de trabalho do educador social ajudaria na falta de clareza de seu trabalho, uma vez que auxiliaria na busca de um profissional que teria que, além de praticar o específico da sua profissão, atender a um grupo de demandas tão multiformes e tão específicas quanto a sua habilidade.

$\mathrm{O}$ trabalho em equipe pelos autores que estudam educação social como Romans, Petrus e Trilla (2003, p. 121) e Garrido, Grau e Sedano (2001, p. 97) - colocado como fundamental no trabalho dos educadores sociais, não suaviza a complexidade da constituição do educador social, uma vez que aglutina sobre um mesmo grupo formaçóes e áreas de constituição científica diferentes, que tendem a visualizar o mesmo educando sob o seu olhar profissional.

No contexto brasileiro, esse esfacelamento do conceito de educador social enquanto grupo profissional pode ser considerado reflexo de como o Estado Brasileiro ainda não tem clara a figura desse profissional em seu amplo campo de trabalho social com as diversas camadas empobrecidas.

A Lei no 7.644, de 18 de dezembro de 1987, foi uma das primeiras a regulamentar a atividade de um profissional responsável pela educação na área da assistência social. A Lei regulamenta a atividade das conhecidas "mães sociais", responsáveis como expresso no Art. 1, da lei, em "propiciar ao menor condiçôes familiares ideais ao seu desenvolvimento e reintegraçáo social." Neste modelo de assistência empregado nos anos 80, as 
crianças eram recolhidas em casas lares ${ }^{2}$ onde eram educadas por este profissional com atribuiçôes delimitadas pela lei. ${ }^{3}$

O modelo das casas lares foi sendo abandonado a partir da aplicação paulatina da Lei 8.069/1990, ou seja, o ECA, no trabalho de assistência a criança e ao adolescente. O esforço do Estatuto é a manutenção da criança e do adolescente no seio familiar - conforme o Art.19 - sendo a transferência para famílias substitutas casos excepcionais. Desta forma, a função deste educador tratado na Lei como 'mãe social' vai perdendo o seu espaço, uma vez que as casas lares vão perdendo sua importância para a legitimação da criança vulnerável no seio familiar.

Por outro lado, o Estatuto reafirma a importância de uma educação integrada que abarque as estruturas formais e sociais do ser humano e que deve ser oferecida pelo Estado e pela sociedade civil ${ }^{4}$. Para este trabalho, serão necessários profissionais que defendam os direitos das camadas vulneráveis e que atendam suas necessidades.

A única alusão feita pelo Estatuto sobre como devem ser os profissionais que atenderão às necessidades sociais destes menores - ou seja, aqueles que exercerão a função de educadores sociais - encontra-se nos Artigos 90 a 97 que falam sobre as Entidades de Atendimento governamentais ou náo governamentais de amparo à criança e ao adolescente. No Artigo 91, a respeito da autorização dada às entidades não governamentais para que funcionem em seu trabalho de assistência, a letra ' $d$ ' relata sobre a obrigação de que a instituição que queira o registro para o funcionamento deva ter "[...] em seus quadros pessoas idôneas."

A idoneidade - um conceito amplo e subjetivo - passa a ser o único parâmetro colocado pelo Estado para que alguém possa exercer a função

2 Segundo Art. 30: "Entende-se como casa-lar a unidade residencial sob responsabilidade de mãe social, que abrigue até 10 (dez) menores".

3 Segundo o Art 4o: "São atribuiçóes da mãe social: I - propiciar o surgimento de condiçôes próprias de uma família, orientando e assistindo os menores colocados sob seus cuidados; II - administrar o lar, realizando e organizando as tarefas a ele pertinentes; III- dedicar-se, com exclusividade, aos menores e à casa-lar que lhes forem confiados. Parágrafo único. A mãe social, enquanto no desempenho de suas atribuições, deverá residir, juntamente com os menores que lhe forem confiados, na casa-lar que lhe for destinada".

4 Cf. Art. 53: "A criança e o adolescente têm direito à educação, visando ao pleno desenvolvimento de sua pessoa, preparo para o exercício da cidadania e qualificação para o trabalho". 
de assistência sócio-educacional. Assim, fica a critério das ONGs e outras entidades governamentais de assistência criarem seus próprios critérios de julgamento para idoneidade e capacidade dos educadores em exercer uma atividade específica com a camada empobrecida, em regime aberto ou fechado de assistência.

Esta aparente falta de clareza sobre a função e organização em torno do ser profissional desse educador social é retratada pela própria legislação. Em 2007, o projeto de Lei no 1.287, de 12 de junho de 2007, pede a alteração do Estatuto do Desarmamento com a seguinte ementa: "Autoriza o porte de arma de fogo aos educadores sociais, agentes de segurança e a outros integrantes de quadros que atuem em estabelecimentos de internaçáo de menores infratores". Este projeto foi arquivado em 20 de fevereiro de 2008, pela Câmara dos Deputados. ${ }^{5}$

No Rio de Janeiro, o projeto de Lei no 1.770 , de 26 de março de 2008, pede à legislação estadual a definição sobre as atividades do Educador Social no Rio de Janeiro. Os próprios educadores sociais, através da regional do Rio de Janeiro do Sinbfir - Sindicato das instituiçóes beneficentes, filantrópicas e religiosas - demonstraram a sua insatisfação à redação do projeto que os colocava em seu Artigo 1 como "[...] classe auxiliar de assistência social” e no seu Artigo 2 exigia apenas o ensino fundamental completo para pertencimento à categoria.

Em janeiro de 2009, os Educadores Sociais conseguiram uma importante conquista no processo de reconhecimento social de sua profissáo e de sua identidade trabalhista. O Ministério do Trabalho incluiu a categoria "Educador Social" no grupo de função profissional, com o código 5.153-05, correspondente aos "trabalhadores de atenção, defesa e proteção a pessoas em situação de risco". A descrição de sua atividade está dada da seguinte forma:

Visam garantir a atenção, defesa e proteção a pessoas em situaçôes de risco pessoal e social. Procuram assegurar seus direitos, abordando-as, sensibilizando-as, identificando suas necessidades e demandas e desenvolvendo atividades e tratamento.6

5 Este texto pode ser acessado pelo site: <http://www.camara.gov.br>.

6 A Classificação Brasileira de Ocupaçóes (COB) organizada pelo Ministério do Trabalho e Emprego pode ser acessada pelo site: <http://www.mtecbo.gov.br>. 
Na mesma categoria ocupacional, onde também se inserem outros considerados educadores no social (como arte educador, educador de rua, educador social de rua, instrutor educacional e orientador socioeducativo), encontram-se também as seguintes ocupaçóes: o de agente de ação social (Agente de proteção social, Agente de proteção social de rua, Agente social); o de monitor de dependente químico (Conselheiro de dependente químico, Consultor em dependência química) e o de Conselheiro tutelar.

$\mathrm{O}$ esforço do Ministério do Trabalho em delimitar o trabalho do educador social e assim também a sua funcionalidade no espaço institucional não governamental ainda náo confere a esta categoria o patamar de uma profissão. Mas, o projeto de Lei no 5.346, de 03 de junho de 2009, que segue em tramitação no Congresso Nacional, dispóe sobre a criação da profissão de Educador social no Brasil.

A fundamentação legal deste projeto está na Lei de Diretrizes e Bases da Educação no 9.394/1996, a qual reconhece que a educação abrange processos cognitivos que possuem o meio social e suas instituiçóes como lugar privilegiado do seu desenvolvimento, preparando o educador social para o exercício da cidadania e o trabalho. ${ }^{7}$

Desta forma, a promulgação de regulamentação da profissão do educador social teria a seguinte finalidade: estabelecer os campos de atuação do educador social (Art. 2); a responsabilidade de uma formação específica para a profissão segundo a Organização do Ministério da Educação, assim como a escolarização mínima para o exercício da profissão (Art. 3) e a organizaçáo da União e seus estados na promoçáo de cargos públicos de educadores sociais e os planos de cargos, carreira e remuneração (Arts. 4 e 5).

Conforme a justificativa apresentada pelo Deputado Federal do Ceará, Sr. Chico Lopes, autor do projeto de Lei em questão,

Cf. Art. 10: "A educação abrange os processos formativos que se desenvolvem na vida familiar, na convivência humana, no trabalho, nas instituições de ensino e pesquisa, nos movimentos sociais e organizaçóes da sociedade civil e nas manifestaçóes culturais. $\$ 1^{\text {o }}$ Esta Lei disciplina a educação escolar, que se desenvolve, predominantemente, por meio do ensino, em instituições próprias. $\$ 2^{\circ}$ A educação escolar deverá vincular-se ao mundo do trabalho e a prática social." Continuando, no Art. $2^{\circ}$, sobre a finalidade da educaçáo nacional: "A educação, dever da família e do Estado, inspirada nos princípios de liberdade e nos ideais de solidariedade humana, tem por finalidade o pleno desenvolvimento do educando, seu preparo para o exercício da cidadania e sua qualificação para o trabalho." 
A criação da profissão de Educador e Educadora Social, além de valorizar estes agentes que tanto contribuem para o enfrentamento da dívida social brasileira, pode suscitar importantes debates acerca da educaçáo no seu sentido mais pleno, com a abrangência que lhe dá o Artigo $1^{\circ}$ da Lei de Diretrizes e Bases da Educação Nacional, respondendo ao genuíno atendimento de interesses e necessidades sociais de nosso tempo. ${ }^{8}$

Conjuntamente a esse projeto de regulamentação da profissão do Educador social com características em âmbito nacional, tramita no congresso Nacional o projeto de Lei no 2.989, de 11 de março de 2008, do mesmo autor, que busca instituir o Dia do Educador Social no Brasil a ser comemorado no dia 19 de setembro por ocasião da data natalícia do educador Paulo Freire.

Recentemente esta discussão continua sendo acirrada sobre a regularização desta categoria profissional. Em 2015, foi aprovado o Projeto de Lei 328 do Senador Telmário Mota pelo estado de Roraima que também busca regulamentar a profissão do educador social, porém com duas características diferentes do projeto de Lei apresentado em 2009: a ampliação da atuação do educador social para fora e dentro da escola (Art. 2); a obrigatoriedade do governo para a criaçáo de cargos públicos para educador social (Art. 3); a formação mínima do educador social para além do ensino médio (Art.3, II); e a delimitação mais específica das atribuiçôes do educador social (Art.4).

Por fim, com todo esse empenho no campo da legislação brasileira, o grupo social 'Educador Social' busca o reconhecimento de sua prática educativa na sociedade brasileira, a valorização da educação não formal empregada pelas instituiçóes em que trabalham como instrumento de atendimento das necessidades das camadas empobrecidas e uma identidade profissional através de conjunto de medidas legais que os organizem como um grupo comum, para além das multiformaçóes dos seus sujeitos, reconhecido pelos seus direitos e deveres.

8 Este texto pode ser acessado na íntegra no site: <www.camara.gov.br/sileg/>. 


\section{O Educador social: formas de ação e de construçáo de uma identidade em serviço}

A figura do educador social continua sendo gerada no panorama educacional brasileiro. O processo de construção do seu 'ser profissional' ainda se manifesta em aberto na diversidade de práticas realizadas em prol das camadas empobrecidas. Isso mostra a necessidade de uma regulamentação específica que delimite o seu trabalho no campo multidisciplinar do seu ambiente de trabalho. Essa atitude ajudaria na superação da imagem social do 'ser educador social' constituída tanto pela sociedade quanto pelos próprios educadores em se sentirem como 'equilibradores de pratos' das distintas demandas e conflitos sociais que lhes são colocados para serem solucionados na relaçáo entre os sujeitos empobrecidos e a sociedade civil.

O ser profissional do educador social se torna um 'espaço' privilegiado para o desenvolvimento de diversas representaçóes que atravessam o seu trabalho social. A gestação conceitual de sua profissão promove, na realidade educacional brasileira, a confluência de objetivos, práticas e conceitos oriundos de diferentes grupos profissionais - da área de educação, saúde, direito, assistência social, dentre outros - que se colocam sobre uma mesma categoria profissional (educador social) determinada pela legislação brasileira às instituições socioeducativas existentes no país.

Sendo assim, o educador social não consegue uma identificação que o defina como um sujeito profissional de características próprias sem a associação com outras categorias profissionais já existentes na sociedade brasileira. Essa realidade dificulta a sua organização sindical como profissionais da educação, o reconhecimento social diante dos aparelhos públicos das secretarias de desenvolvimento social nos diversos municípios brasileiros e da valorização econômica de sua força de trabalho na sociedade Brasileira.

O diálogo entre as representaçóes oriundas da vivência com a pobreza e a formação da identidade do educador social se faz imprescindível para duas açóes concretas: a de formar açôes inclusivas que deem visibilidade do atendimento realizado por esses profissionais aos grupos à margem da sociedade brasileira e a possibilidade de organizar uma formação mínima para que esses profissionais sejam atendidos em seu trabalho cotidiano junto às camadas empobrecidas.

Segundo Ferreira (2012), essa relação entre as representações de pobreza e a realidade formativa vivenciada pelo educador social ajudará a 
compreender como se constitui o processo de sua identidade profissional e como esta se torna a marca característica, ou não, da existência e pertença grupal dos educadores que se movimentam em um ambiente pedagógico, caracterizado pelas constantes mudanças sociais que determinam diretamente a realização, ou não, de suas práticas.

Os trabalhos no campo teórico da Pedagogia Social na/para formação de educadores sociais (e porque também não pensar na formação docente?) devem fomentar o reconhecimento das diversos conceitos, valores, crenças e representaçóes existentes no trabalho profissional desse educador, auxiliando-o na contínua reconstruçáo de sua identidade que reside, essencialmente, no serviço prestado às camadas empobrecidas e suas demandas sociais. A realidade social deve ser o início para o trabalho de formação inicial dos educadores sociais, fomentando o começo de uma formaçáo continuada mais completa e complexa que forjará a identidade profissional desse educador na realidade concreta da sociedade brasileira, no seu tempo histórico e na sua relação direta com os grupos, em situação de vulnerabilidade social.

A formaçáo inicial do educador social, tendo como base a história da educação popular no Brasil, seus principais teóricos e as formas de atuação na contemporaneidade, é fundamental para que os futuros educadores sociais, seja de ensino médio seja de ensino superior, ancorem os princípios de sua ação socioeducativa em uma atuação interdisciplinar, que exigirá nos serviços prestados junto à população empobrecida, formar novas açóes, permanentemente.

\section{Referências}

BRASIL. Lei no 7.644, de 18 de dezembro de 1987. Dispóe sobre a regulamentação da atividade de mãe social e dá outras providências. Diário Oficial da República Federativa do Brasil, Poder Executivo, Brasília, DF, 21 dez. 1987.

. Lei no 8.069, de 13 de julho de 1990. Dispóe sobre o Estatuto da Criança e do Adolescente. Diário Oficial da República Federativa do Brasil, Poder Executivo, Brasília, DF, 16 jul. 1990.

FERREIRA, Arthur Vianna. Representaçóes Sociais e Identidade Profissional: Elementos das práticas educacionais com os pobres. Rio de Janeiro: Letra Capital, 2012. 
FREIRE, Paulo. Pedagogia da Autonomia. São Paulo: Ed. Paz e Terra, 1996. . Pedagogia da Esperança. São Paulo: Ed. Paz e Terra, 2001. Pedagogia do Oprimido. São Paulo: Ed. Paz e Terra, 2005.

GARRIDO, José Luis Garcia; GRAU, Carmen-José Alejos; SEDANO, Alfredo Rodriguez. Esquemas de Pedagogia Social. Navarra: Ed. EUNSA, 2001.

KHULMANN JR, Moysés. A circulação das ideias sobre a educação das crianças no Brasil do século XX. In: FREITAS, Marcos Cezar; KHULMANN JR, Moysés (Orgs.). Os intelectuais na História da Infância. São Paulo: Cortez Editora, 2002.

MARCILIO, Maria Luiza. História social da criança abandonada. São Paulo: HUCITEC, 2006.

MORAES, Carmem Sylvia Vidigal. A socializaçáo da força de trabalho: instrução popular e qualificação profissional no Estado de São Paulo. Bragança Paulista: EDUSF, 2003.

ROMANS, Mercè; PETRUS, Antoni; TRILLA, Jaume. Profissão: Educador Social. Porto Alegre: Artmed, 2003.

VENÂNCIO, Renato Pinto. Famílias Abandonadas: Assistência a crianças de camadas populares no Rio de Janeiro e Salvador. Campinas: Papirus, 1999.

ZITKOSKI, Paulo José. Paulo freire \& Educação. Rio de Janeiro: Autêntica, 2010. 


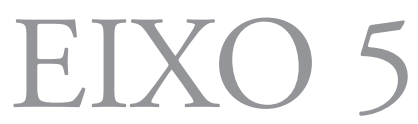

A educação nas relações étnico-raciais 


\title{
A CIBERCULTURA NO COMBATE AO RACISMO E A DISCRIMINAÇÁO AFRORELIGIOSA
}

\author{
Luzineide Miranda Borges ${ }^{1}$
}

O meu cabelo não pediu sua opiniāo!

\section{A coisa está ficando preta: ativismo digital e educação para a diversidade cultural}

A frase acima viralizou nas redes sociais digitais, ganhou espaços nas camisas das meninas negras e meninos negros que estão reexistindo a toda forma de preconceito e lutando contra a discriminação racial digital. $\mathrm{O}$ digital, em rede, inaugura uma nova forma de comunicaçáo e revoluciona os modelos comunicacionais na contemporaneidade. Saímos da comunicação/informação passiva, em que as pessoas recebiam essas informaçóes e não tinham como expressar suas críticas e reflexôes sobre elas, para a comunicação/interação.

É cada vez mais comum acessarmos as redes sociais digitais e encontrarmos várias formas de interação e colaboração acerca do que está acontecendo no mundo. Expressóes como "o que você está pensando", "deixe aqui sua opiniâo" e "qual a sua sugestão" caracterizam a Cibercultura como espaço de cocriação e participação ativa. Saímos da era leitor para leitor/autor. O digital em rede parte do princípio de que as pessoas têm sempre o que contribuir, estão engajadas e fazem parte desse movimento não como expectador, mas como autores. São para elas e sobre elas que a cada dia os desenvolvedores e programadores de software criam e recriam aplicativos na internet (SANTOS; SANTOS, 2012).

1 Mestra em educação, pela Universidade Estadual da Bahia - UNEB; Professora assistente, no Departamento de Ciências da Educação, da Universidade Estadual de Santa Cruz - Ilhéus-BA. Doutoranda do Programa de Pós-Graduação em Educação - ProPed da Universidade do Estado do Rio de Janeiro. Membro dos Grupos de Pesquisas: Ilè Obà Òyó, Multi-Institucional Áfricas <www.grupoafricas.wix.com/site> e Formação de Professores, Currículo e Alfabetização/UESC. E-mail: <neide.luzi@gmail.com>. 
Essa geração que está nas escolas e nas redes sociais digitais é composta de pessoas que têm sua história de vida cruzada pelas relaçóes do seu cotidiano. São estudantes que têm uma concepção cultural sobre gênero, cor e religiosidade construída no espaçotempo ${ }^{2}$ da sua vida dentrofora da escola. $\mathrm{O}$ que circula nas redes sociais digitais são suas vivências nas relaçóes intercruzadas nesse espaçotempo.

Tentando compreender como a Cibercultura pode contribuir com o debate sobre a implementação da Lei 10.639/03, analisei o ativismo digital promovido pelo grupo de estudantes da Universidade Estadual de Santa Cruz - UESC que organizaram o coletivo "A coisa está ficando preta", que tem como objetivo criar nas redes sociais online e off-line um espaço de debates críticos e reflexivos de fortalecimento da educação antirracista. Há 13 anos, a Lei de 10.639/03 foi criada, e seu único e principal objetivo é tornar obrigatório o ensino da história e cultura afro-brasileiras e africanas em todas as escolas, públicas e particulares, da educação básica. Porém, como toda lei no Brasil, até o presente momento teve pouco avanço, pois muitas escolas a interpretaram de forma muito superficial, resumindo o ensino da história e da cultura afro-brasileira e africana a datas comemorativas pontuais. E a Cibercultura com isso?

Bem, através do ativismo digital, o coletivo vem promovendo, desde 2014, várias campanhas em sua página no Facebook, desconstruindo o que a mídia de massa fala sobre os negros. São marcas consolidadas, nas quais o negro acreditou na sua inferioridade, se vendo como algo errado, feio. Entáo percebemos assim que a construção de uma identidade está nas nossas relaçôes com os outros e com nós mesmos (Aline, ativista digital do Coletivo).

Os coletivos digitais que vêm com essa proposta de empoderamento dos negros têm se multiplicado a cada dia. A diferença como algo positivo

2 Espaçotempo e Dentrofora. Esses termos, utilizados por Nilda Alves para substituir os tradicionais espaço e tempo e dentro e fora, aparecem dessa maneira para mostrar como o modo dicotomizado de analisar a realidade, que herdamos da ciência moderna, significa limites ao desenvolvimento das pesquisas nos/dos/com os cotidianos. Achamos coerente utilizar essa forma de grafar para examinar as ideias de Cibercultura e outros temas da contemporaneidade. 
é pautada na relação social que priorize o respeito ao outro como portador e produtor de cultura, saber e criatividade, que influencia na nossa formação e como a educação, a cultura e a história podem ajudar na reconstrução de uma identidade brasileira, agora fundamentada no reconhecimento de uma população brasileira consciente de sua formação multirracial, na qual o negro se reconheça como parte da sociedade (MUNANGA, 2005).

Optei por observar o trabalho desenvolvido pelo coletivo "A coisa está ficando preta" por este estar localizado numa regiáo de pouca ou quase nenhuma visibilidade da cultura afro-brasileira. $\mathrm{O}$ sul da Bahia é marcado historicamente pelo silenciamento e apagamento da contribuição cultural e histórica dos afro-brasileiros. O coletivo foi criado em 2014, e conta com a parceria do Kàwé/UESC ${ }^{3}$, LAIKOS/UESC ${ }^{4}$ e AMATA - Associação Mantenedora do Terreiro Ilê Axé Odé Aladê Ijexá. O objetivo do Coletivo é o ativismo digital na luta contra a discriminação racial e religiosa. Para isso, vem desenvolvendo várias campanhas no Facebook com o foco na midiatização da cultura afro-brasileira a partir da compreensão do nós por nós fundamentada na filosofia africana $U b u n t u^{6}$.

Este artigo é resultado da etnografia virtual desenvolvida a partir da análise das publicaçóes realizadas pelo Coletivo durante o ano de 2014 e 2015, em sua página no Facebook .

Uma das características da etnografia virtual é o redimensionamento do tempo e do espaço ocupados pelo pesquisador. Utilizando-se de suporte digital, o pesquisador não precisa se deslocar para estar no campo de pesquisa. O tempo de comunicação com os participantes da pesquisa

3 Kàwé palavra ioruba que significa Educação é o nome do Núcleo de Estudos Afro-Baianos Regionais da UESC/BA.

4 Projeto de extensão LAIKOS: enfrentando a intolerância religiosa e promovendo a igualdade racial, do Departamento de Ciências Jurídicas da UESC.

5 Terreiro localizado no Banco da Vitória em Ilhéus-BA. As palavras em yoruba Ilê Axé Odé Aladê Ijexá significam: Casa de axé do Rei Oxóssi da nação Ijexá.

6 Todos os textos do "Por dentro da África" estão disponíveis em PDF no ícone no final da página. O conteúdo deve ser utilizado com propósito educativo. Para republicaçóes em outros canais, entre em contato com o site. Por dentro da África <http:// www.pordentrodaafrica.com/cultura/ubuntu-filosofia-africana-que-nutre-o-conceito-de-humanidade-em-sua-essencia>.

7 Endereço do Coletivo "A Coisa Está Ficando Preta” no Facebook: <https://www.facebook.com/acoisataficandopreta/?fref=ts $>$. 
não será o tradicional. Eles podem combinar qual o melhor horário para conversar. Uma das críticas que os etnógrafos tradicionais fazem a esse tipo de pesquisa é quanto ao encontro face a face (AMARAL; NATAL; VIANA 2008). Com os avanços tecnológicos, temos à nossa disposição recursos midiáticos que nos permitem fazer entrevistas online, utilizando a videoconferência em tempo real. Pela chamada em vídeo é possível analisar os gestos e emoçóes expressas pelos participantes da pesquisa. Assim, a netnografia ou a etnografia virtual produz dados das pesquisas comunicacionais sincrônicas através de entrevistas online, utilizando recursos de telepresenças online via skipe/Facebook e ligaçôes via whatsapp, como também narrativas digitais assíncronas disponibilizadas nas redes sociais digitais, tais como: comentários, fotografias e vídeos.

Uma etnografia virtual pode observar com detalhe as formas de experimentaçáo do uso de uma tecnologia, se fortalecendo como método justamente por sua falta de receita, sendo um artefato e não um método protocolar, é uma metodologia inseparável do contexto onde se desenvolve, sendo considerada adaptativa (AMARAL; NATAL; VIANA, 2008, p. 4).

Durante esses dois anos, venho acompanhando as postagens do Coletivo, que falam da negritude das crianças e jovens da região de Ilhéus e Itabuna-BA, utilizando o digital em rede para o empoderamento dessa juventude e afirmação da sua identidade afro-brasileira. Neste estudo, observo as narrativas digitais: comentários, fotografias e vídeos produzidos e postados pelos participantes do Coletivo.

\section{A Cibercultura e as relaçóes étnico-raciais: um referencial para educaçáo}

A primeira campanha analisada foi à campanha "Dia das mães é todo dia... Respeito é o melhor presente", desenvolvida em maio de 2014, em homenagem ao Dia das Mães.

O Coletivo convidou a mãe Darabi, İyálorixa do terreiro Ilê Odé

8 Sacerdotisa do culto aos orixás. 
Figura 1 - Campanha: Dia das mães é todo dia... Respeito é o melhor presente

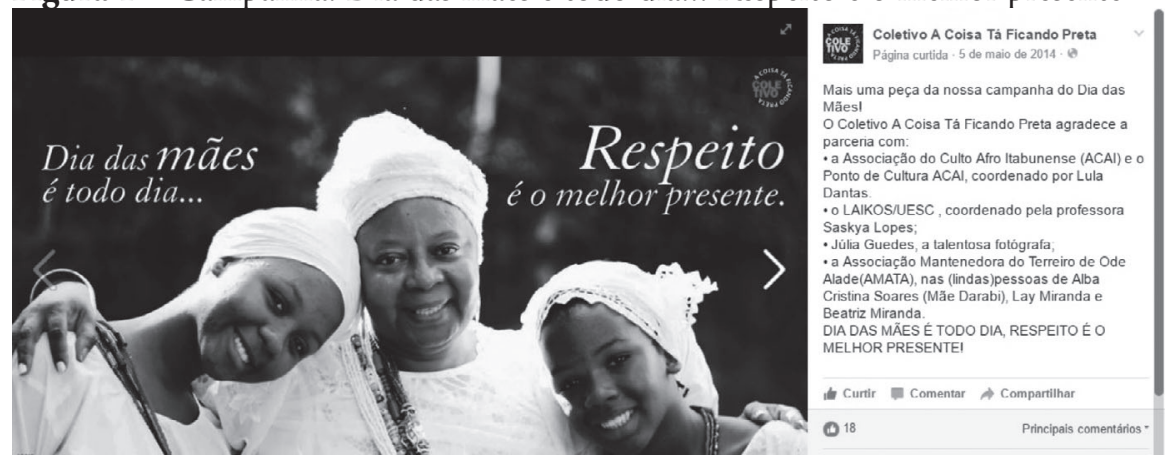

Fonte: Página do Facebook do Coletivo A coisa está ficando preta

Aladê Ijexá, para participar dessa campanha. "Eles me convidaram, disseram que queriam minha participação, mas você já viu mãe sem filho?

Nem eu! Aí convidei minhas duas filhas lindas, Beatriz Miranda e Layza Miranda, para participarem dessa campanha comigo", diz mãe Darabi numa conversa que tivemos inbox no Messenger do Facebook.

Além da campanha no Facebook, o Coletivo imprimiu cartazes que foram distribuídos na UESC e nas escolas públicas da região. Também foi fixada num outdoor na Rodovia Jorge Amado (entre as cidades de Ilhéus e Itabuna). As meninas que participaram dessa campanha, na época, eram estudantes do ensino fundamental e frequentavam uma escola particular em Ilhéus.

Segundo as meninas, Beatriz Miranda e Layza Miranda, no início da campanha, quando seus colegas as identificavam nos cartazes e perguntavam se elas eram do Candomblé, elas diziam que não, que tinham participado da campanha, porque eram modelos fotográficas: "Com a repercussão da campanha no Facebook e muita gente curtindo e compartilhando as nossas fotos e dizendo que respeitavam quem era do axé, aí comecei a dizer que era do Candomblé, mas no início eu tinha vergonha”, diz Beatriz, com um dos cartazes na mão.

As curtidas e compartilhamentos das postagens dessa campanha foram para essas meninas a sinalização de que não tinham do que se envergonhar e tampouco se esconder. Os negros africanos, quando chegaram às Américas, especialmente ao Brasil, encontraram nas redes sociais presenciais, resistência, acolhimento e afeto para preservarem suas vidas, primeiro, e depois se constituírem enquanto cidadãos afro-brasileiros. Desde que o 
Brasil é Brasil, vivemos em comunidades, em redes, seja em volta da fogueira depois de um dia intenso de trabalho, quando o Brasil era colônia, seja nos grupos sociais, no final de semana, depois do futebol ou grupo de dança. Estamos sempre com o outro, o nosso semelhante ou o nosso diferente, e é com ele que dividimos os nossos saberes, angústias, alegrias, dúvidas, lutas e conquistas.

Com o digital em rede, a nossa rede de relacionamento ampliou e foi ressignificada, nossos amigos de hoje náo são apenas as pessoas que conhecemos na rua, na escola ou no trabalho, sáo também as pessoas que conhecemos nos eventos próximos de nossa casa ou é aquela pessoa que fez um vídeo ${ }^{9}$ bacana, postou na internet e todos estáo comentando e querendo conhecer. É alguém que acabou de lançar um livro muito interessante e, para convidar as pessoas para o lançamento, criou um evento no facebook. Sem falar nas manifestaçóes e atos políticos, nas feiras e eventos culturais que são organizados e divulgados nas redes digitais. Ou seja, as redes sociais digitais não só ressignificaram o conceito das relaçóes sociais na contemporaneidade, como também têm possibilitado uma conexão com pessoas e seus saberes/produçôes, independente da localização geográfica. Aproximam interesses políticos, culturais, sociais e educacionais, potencializam novas reflexóes e ampliam a inteligibilidade do mundo no mundo, em tempo real.

O ponto crucial é que o ciberespaço é, ao mesmo tempo, coletivo e interativo, uma relação indissociável entre o social e a técnica. Essa perspectiva nos leva a pensar o ciberespaço, então, como um potencializador de infinitas açóes interativas, um novo espaço de comunicação, de sociabilidade, de reconfiguraçáo e de autorias (SANTOS; SANTOS, 2012, p. 5).

O Facebook apresenta-se também como um espaço de diálogo, afetividade e de luta de interesses, propiciando uma diminuição de fronteiras entre uma série de pessoas que podem participar desses espaços e também no off-line. O bacana nessa campanha foi a forma como as pessoas "vestiram a camisa" para falar da discriminação religiosa e do papel da mulher

9 São os famosos Youtubers, jovens e adolescentes que fazem vídeos do seu cotidiano para o Google e estão saindo do Youtube para a TV, cinema e livrarias. 
negra e mãe de santo na nossa sociedade. A compreensão de que devemos respeitar o lugar que ela ocupa na formação social e cultural dos adeptos do Candomblé foi uma das questóes mais relevantes da campanha. Outro fato interessante foi o cruzamento das redes. As pessoas tiravam fotos com o cartaz nas mãos e compartilhavam na página do Coletivo "A coisa está ficando preta".

Figura 2 - Postagem dos alunos do mestrado acadêmico em Letras da UESC

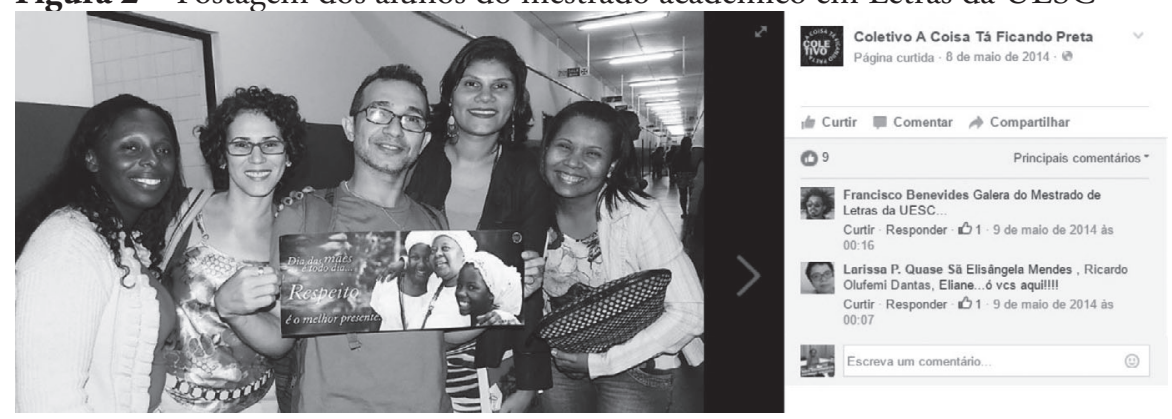

Fonte: Página do Facebook do Coletivo A coisa está ficando preta.

Outra campanha do Coletivo que observei foi a do Dia dos Namorados. A campanha resgatou, em 2014, a campanha realizada pelo Movimento Negro Unificado (MNU) há 24 anos. Em 1991, no Jornal do MNU, a campanha Reaja à violência racial: beije sua preta em praça públi$c a$. Essa campanha foi ressignificada pelo coletivo no Facebook através do tema: Teu Afeto me Afirma e me Empodera.

Inicialmente, o Coletivo compartilhou várias fotografias produzidas por eles para a campanha. A primeira imagem foi uma montagem feita com a fotografia realizada pelo MNU, em 1991, e uma fotografia do Coletivo produzida em 2014, com uma frase para lembrar os 23 anos da campanha.

Figura 3 - Campanha Teu Afeto me Afirma e me Empodera

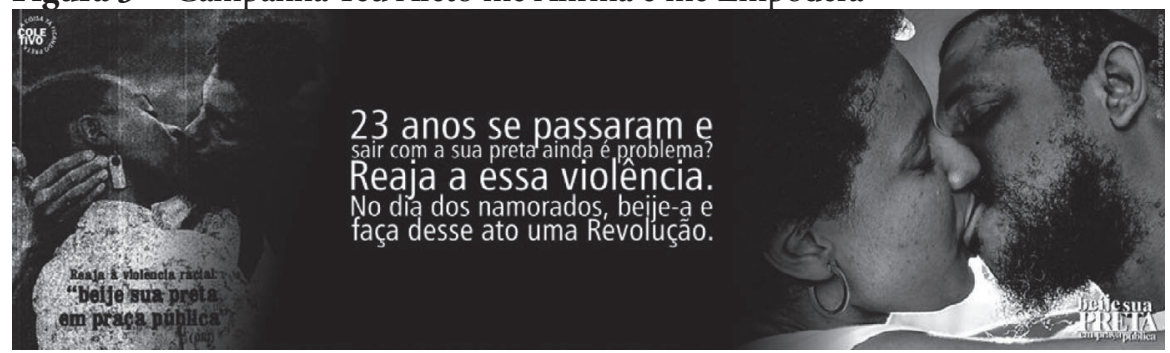

Fonte: Facebook Coletivo $A$ coisa está ficando preta. 
Em seguida, as pessoas começaram a mandar as suas fotografias tiradas em diversos lugares públicos, como praça pública, praias, barzinhos, shoppings. As imagens chamavam a atenção por atrelar a afetividade negra à violência racial. A proposta da campanha foi chamar a atenção da juventude negra contra o racismo, que ainda é táo atual quanto suas várias facetas.

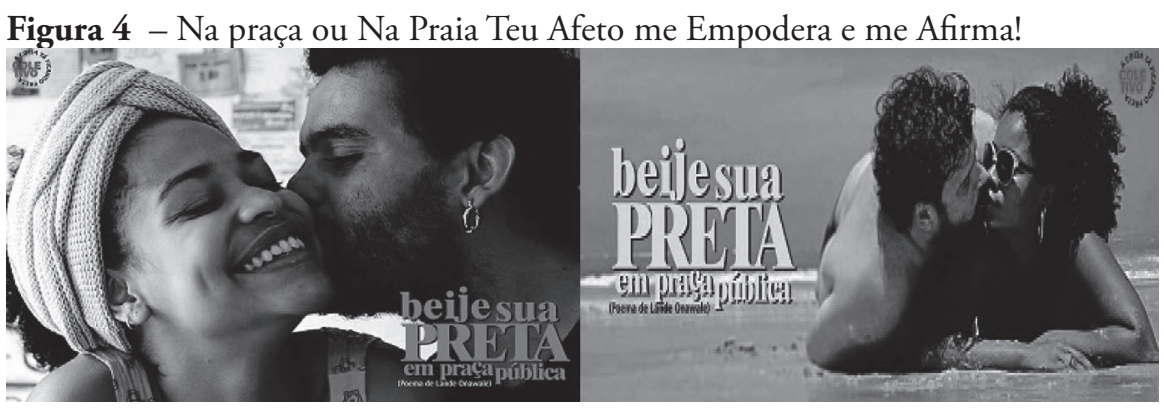

Fonte: Página do Facebook Coletivo A coisa está ficando preta.

A frase da legenda acima é do casal, ao lado direito Manoella e Wruahy, na sua fotografia postada na timeline do Coletivo. A ausência de casais negros nos comerciais veiculados na TV ou em outdoors, nas revistas, jornais, novelas e filmes da mídia de massa ainda é uma visão da sociedade do embranquecimento e uma forma de violência racial. Sem representatividade, não temos do que nos orgulhar. Essa campanha foi tão representativa para a juventude negra que durou mais que o esperado. Era para ficar até o Dia dos Namorados, mas as imagens e comentários náo paravam de chegar à timeline do Coletivo. E, além de mandarem suas fotografias, as pessoas comentavam sobre a campanha.

Gente!!! Essa \#Campanha Teu Afeto Me Afirma e Me Empodera do Coletivo [...] tem nos feito pensar um bocado. 1. Para além de se "amostrar no face", vejo que os casais ficam felizes em expressarem o seu amor. Massa. 2. O "beije sua preta" causa um furor identitário!! Lande Onawale futucou nossas entranhas com este poema. Explico-me: as pessoas querem enviar fotos, mas ficam naquela "será que eu sou essa preta que eles estão falando?", "Eu queria, mas eu sou moreno, não sou preto" "No casal, só tem um preto. Pode?", "Existe preta de cabelo liso?". Ou seja: massa ao quadrado!! Refletir sobre o nosso pertencimento racial é uma das coisas mais poderosas 
e necessárias no processo de afirmação identitária. Eu mesma sou uma preta de pele clara, "negra com pouca tinta", como me disse uma vez o professor Ubiratan Castro de Araújo, mas tenho plena consciência do quanto a extensa variação de autodefiniçóes de cor/raça no Brasil é problemática e interfere nos padróes de discriminação racial. Enfim, colocar nossas imagens pretas na mídia (rede social) implica mexer num vespeiro tanto nas nossas cabeças quanto no discurso racista de nossa sociedade. Suspiro. Continuemos na luta... As coisas estão ficando maravilhosamente pretas!!!! Coletivo A coisa está ficando preta (Larissa Quase Sã).

Uma identidade se forma através da sociedade, da cultura, dos lugares, das histórias, das pessoas com as quais convivemos e dos costumes. Por isso, "é preciso que haja a aceitação de nós por nós mesmos, cada um fazendo suas próprias escolhas”, escreve Tiago Carvalho em um dos vários comentários na página do Coletivo no Facebook.

Para o fortalecimento dessa questáo é interessante trazer o posicionamento de Munanga (2005), quando diz que o resgate da memória coletiva e da história do povo negro não é interessante só para os alunos de descendência negra, mas para todos, principalmente os de descendência branca.

Interessa também aos alunos de outras ascendências étnicas, principalmente brancas, pois ao receberem uma educação envenenada pelos preconceitos, eles também tiveram suas estruturas psíquicas afetadas. Além disso, essa memória não pertence somente aos negros. Ela pertence a todos, tendo em vista que a cultura da qual nos alimentamos quotidianamente é fruto de todos os segmentos étnicos que, apesar das condiçôes desiguais nas quais se desenvolvem, contribuíram cada um de seu modo na formação da riqueza econômica e social e da identidade nacional (MUNANGA, 2005, p. 16).

Com a repercussão da campanha, "Teu Afeto me Afirma e me Empodera", o Coletivo organizou a campanha para o Dia Internacional da Mulher Latino-Americana e Caribenha, em 25/07, e a campanha para o Dia das Crianças. Quem acompanha as propagandas e comerciais da mídia de massa percebe que não existe nenhuma campanha em que as crianças negras sejam maioria ou tenham representatividade positiva de empoderamento. 
Além da falta de representatividade, a população negra sofre com a ausência de sua participação em trabalhos artísticos e culturais de destaque ou em espaços de prestígio. Quando essa aparece na mídia, está desenvolvendo trabalho braçal, como empregado/a da construção civil ou doméstica, em campanha do governo para as políticas assistencialistas ou como segurança de bancos ou porteiro de condomínios de luxo.

Já na campanha do Dia das Crianças, buscou-se pensar em referências negras que poderiam contribuir para a formação da identidade das crianças negras. A proposta foi sensibilizar os pais, os educadores e as crianças, em geral, de que nós somos e pertencemos a um grupo étnico que contribuiu para a formação cultural da população brasileira, com grande participação na música, nas cantigas de roda, nas brincadeiras, nas danças e no esporte. Como também na Medicina, no Direito, na Educação, na Engenharia, na Arquitetura, ou seja, em todas as áreas.

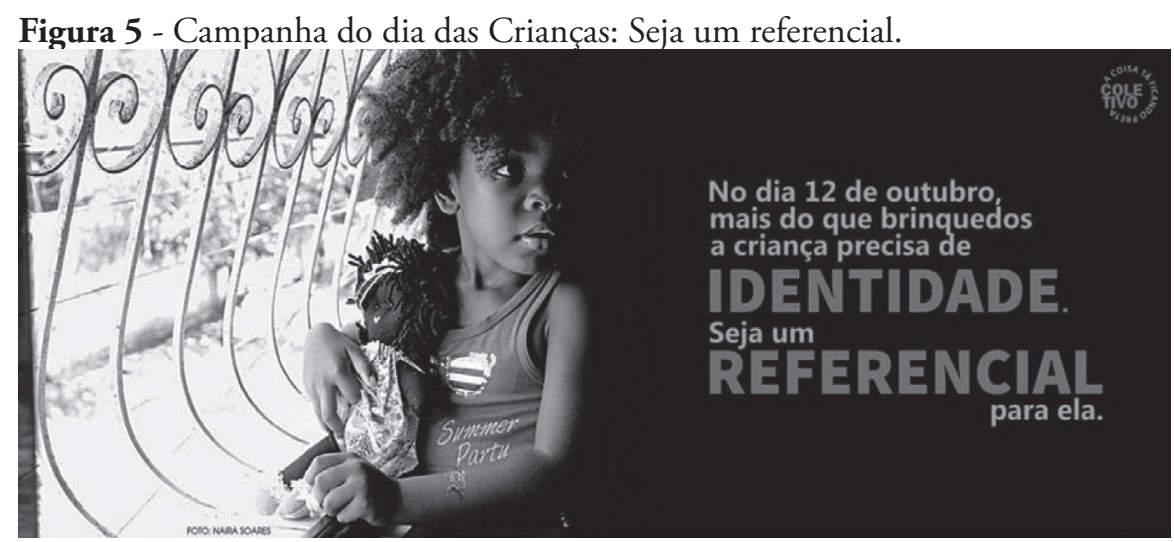

Fonte: Página no Facebook A coisa está ficando preta.

Bem, isso sem falar que quase não circulam bonecas negras na mídia televisiva e no comércio. As crianças negras crescem brincando com a Barbie e as princesas loiras, magras e de olhos azuis como único referencial. Esse estereótipo, também, está presente em toda a literatura infantil que circula pela escola e nas livrarias. Além das postagens no Facebook, o Coletivo organizou visitas às escolas com atividades culturais: roda de conversa, contação de história afro, desfiles afros e confecção de brinquedos, inclusive bonecas negras confeccionadas em tecidos.

E se essas campanhas chegassem à sala de aula? Será que podemos pensar a formação da identidade brasileira para além da cultura branca? 
Podemos falar de afirmação de identidade afro-brasileira? Podemos falar de consciência negra? E podemos fazer uma comparação histórica entre as atividades desenvolvidas pelo MNU, em 1991, e os dias atuais? Podemos falar da juventude de terreiro? Estas e outras questóes nos fazem pensar na formação docente e no ensino da história e cultura afro-brasileira e africana.

O desafio posto para os docentes é a compreensão de que as pessoas, nós, estamos imersos num mundo cada dia mais digitalizado em que as relações são atravessadas pela multiplicidade de acesso à informação e ao conhecimento que nos legitima como um ser no mundo e com o mundo. Se a escola tem dificuldades em problematizar e apresentar o povo brasileiro como uma nação multirracial, as redes sociais digitais vêm nos mostrando que as pessoas que estão conectas não têm nenhuma dificuldade em dar visibilidade às suas origens étnicas, apesar do discurso de ódio também presente no ciberespaço. Encontramos no Facebook relatos diários de violência racial ${ }^{10}$ e religiosa (Candomblé e Umbanda), estética negra, feminismo negro, cultura negra, literatura negra, cinema negro, feira afro e inúmeros eventos culturais, artísticos e políticos. Portanto, educar, é proporcionar condiçôes que permitam o desenvolvimento da autonomia.

Neste sentido, precisamos compreender os vestígios do passado como evidência no seu mais profundo sentido, isto é, como um tema que deve ser tratado náo como mera informação, mas como algo de onde se podem retirar respostas a questóes, é que o conhecimento histórico passa a ter significado.

Por conta disso, como lidar com a diversidade cultural em sala de aula? É possível escapar de um modelo monocultural de ensino? Poderá os professores incluir a equidade de oportunidades de aprendizagem entre seus objetivos? Como socializar, através do currículo e de procedimentos de ensino, para atuar em uma sociedade intercultural e desnaturalizar o racismo?

Esses desafios se apresentam como forma de propor novas metodologias para o ensino de estudos étnicos; reformulação de currículos e ambientes escolares, articulando cultura e identidade; desempenho escolar e

${ }^{10}$ A página Senti na pele tem como objetivo mostrar relatos de pessoas que sofreram algum tipo de discriminação ou injúria racial. Disponível em: <https://www.facebook.com/ sentinapele/?fref=ts $>$. 
diversidade cultural; criar açóes de oportunidades de sucesso escolar para todos os alunos, independentemente de seu grupo social, étnico/racial, religioso, político e de gênero; valorizar a importância da diversidade étnica e cultural na configuração de estilos de vida; e, prioritariamente, a formação inicial e continuada do/a professor/a da educação básica.

Nesse sentido, o papel da Cibercultura é determinante no processo de reapropriação e produção de saberes outros. Através da análise crítica das narrativas digitais que circulam nas redes sociais digitais, como Facebook; dos questionamentos das imagens, vídeos, comentários, da comparação do que se lê com o que se vê e da comparação do que se lê nos textos oficiais com o seu cotidiano, suas experiências e sua cultura. Podem-se, assim, desconstruir estigmas de pertencimentos relacionados a questóes raciais e étnicas.

Outro ponto importante a refletir quando se fala na formação da identidade étnico-racial brasileira é as questóes globais em que cada sujeito está inserido e das quais não podemos nos furtar de uma discussão para além dos comentários no online. Há uma massificação da cultura e também uma capitalização cultural. A cultura afro-brasileira é um produto do mercado globalizado (HALL, 2001; CASTELLS, 1999). A Cibercultura tem uma dinâmica própria fundamentada na fluidez e velocidade das informaçóes. Fazer um diálogo formativo e crítico dos conhecimentos que circulam nas redes sociais digitais e em sala de aula pressupóe ampliar o debate para uma reflexão mais crítica, criteriosa e formativa do que circula no mundo digital. Náo podemos perder de vista que somos afetados direta ou indiretamente com tudo o que acontece no mundo, pois somos sujeitos globalizados.

Sendo assim, a identidade deixa de ser formada pela interação entre "o eu e a sociedade", conforme afirma Hall (2001, p. 11), passando a ser formada pelas "supostas" necessidades do homem, influenciada pela Indústria Cultural, mas também movida pela movimentação, pelos encontros e desencontros. As jovens que buscam força para afirmar a sua identidade religiosa, os jovens que buscam enfretamento na luta por afeto negro em outros casais que também são negros e a criança que tem como presente a referência de outros lugares de ocupação do corpo negro são afetados por processos identitários produzidos nos cruzamentos e circulaçáo de uma imagem de empoderamento e resistência da populaçáo negra na luta por identificação. Desse desenho, admite-se que somos compostos por representaçóes, sendo fundamental compreendermos o mundo por esse olhar, em que as mudanças advêm, as culturas se permutam e as certezas são mutáveis. 
A proposta de utilizar o Facebook como um espaço de reflexão e formação de uma identidade étnico-racial brasileira não é uma solução aos problemas raciais no Brasil, mas uma possibilidade de ampliação dos espaços formativos, uma vez que as redes sociais digitais são muito utilizadas pelos alunos, professores e a comunidade para difusão cultural e o enfrentamento ao racismo estrutural do nosso país.

\section{Temos muito que caminhar...}

Pensar numa educação para a diversidade intercultural mediada pelo digital em rede é um desafio emergente para a educação brasileira. Se por um lado, é uma proposta audaciosa, visto que retira da responsabilidade do professor a transmissão do conhecimento e propóe a formação de espaços de trocas de saberes, historicamente, produzidos pelos afrodescendentes; por outro, é um problema para a estrutura curricular disciplinar e fragmentada, presente nas escolas e na ausência de formação continuada de professores.

Nessa perspectiva, com o objetivo de pensar o modelo tradicional de educação - que embranqueceu o currículo escolar e deslegitimou os negros africanos e afrodescentes de sua participação na formação história e cultural do Brasil — é que se propóe a pensar em abrir espaços para debates, críticas e reflexôes outras; e a inserção dessas tecnologias digitais como possibilidade de promover e construir os valores interculturais numa sociedade que é pautada ainda pela exclusão e discriminação racial.

\section{Referências}

ALVES, N. Apresentação: as múltiplas formas de narrar à escola. Currículo Sem Fronteiras, v. 7, n. 2, p. 5-7, jul./dez., 2007.

AMARAL, A.; NATAL, G.; VIANA, L. Netnografia como aporte metodológico da pesquisa em comunicação digital. Revista Sessóes do Imaginário, Porto Alegre, 20. ed., p. 34-40, dez., 2008.

CANDAU, Vera Maria. (Org.). Educaçáo Intercultural e Cotidiano Escolar. Rio de Janeiro: 7 Letras, 2006. 
CASTELLS, M. A construção da identidade. In: CASTELLS, M. O poder da identidade. São Paulo: Paz e Terra, 1999.

HALL, S. A identidade cultural na pós-modernidade. Tradução Tomás Tadeu da Silva, Guaracira Lopes Louro. 11. ed. Rio de Janeiro: DP\&A, 2001.

MUNANGA, K. Superando o racismo na escola. Brasília: Ministério da Educação, Secretaria de Educação Continuada, Alfabetização e Diversidade (SECAD), 2005.

Negritude: usos e sentidos. São Paulo. Ática, 1986.

PRESIDÊNCIA DA REPÚBLICA; Casa Civil Subchefia para Assuntos Jurídicos Lei 10.639, de 9 de janeiro de 2003, publicado no D.O.U. de 10.1.2003.

SANTOS, E. O; SANTOS, S. R. Cibercultura: redes educativas e práticas cotidianas. Revista Eletrônica Pesquiseduca, v. 4, n. 7, jan./jul., p. 159-183, 2012. 


\title{
O ACESSO E A PERMANÊNCIA DE ESTUDANTES DOS MEIOS POPULARES NO ENSINO SUPERIOR: A PERMANÊNCIA DOS NEGROS NO CURSO DE DIREITO DA UNIVERSIDADE ESTADUAL DO SUDOESTE DA BAHIA (UESB)
}

\author{
Julia Borba Caetité Algarra ${ }^{1}$ \\ Benedito Eugenio ${ }^{2}$
}

\section{Introdução}

Sabe-se que as oportunidades de acesso ao ensino superior são parte de uma "seleção excludente", de mecanismo perverso baseado no número de vagas e na "nota de corte", e se destacam aqueles que têm o maior desempenho durante todo o período escolar, sendo que estes sujeitos, geralmente, são os que fazem parte de um nível social superior aos demais. Bourdieu (2008, p. 41) confirma isto dizendo que "um jovem de camada superior tem oitenta vezes mais chances de entrar na Universidade que o filho de um assalariado agrícola [...]".

O debate sobre as cotas "quebra" esta corrente de privilégios através da implementação, a partir de 2002, das políticas públicas de Ação Afirmativa, "como resposta imediata à III Conferência Mundial contra o Racismo, Discriminação Racial, Xenofobia e Intolerância correlata, realizada em Durban, África do Sul (2001)" (JULIO; STREY, 2009, p. 2). Nesta Conferência, Fernando Henrique Cardoso, presidente da República naquela época, se comprometeu a combater o racismo e a discriminaçáo, "em resposta as pressões do Movimento Negro por políticas de promoção da igualdade racial, e não por mera benevolência e concessão do Estado brasileiro" (ESTÁCIO, 2013 , p. 2). Entáo, foi a partir disso que começaram a se pensar em políticas

1 Graduanda do Curso de Pedagogia da Universidade Estadual do Sudoeste da Bahia UESB, Campus de Vitória da Conquista, Bahia. E-mail: <juuh_algarra@hotmail.com>.

2 Professor adjunto da Universidade Estadual do Sudoeste da Bahia - UESB. E-mail: <beneditoeugenio@bol.com.br>. 
públicas de ação afirmativa, entre elas as cotas nas universidades públicas e as bolsas de estudo nas privadas.

Assim sendo, as cotas são compreendidas enquanto ações compensatórias e distributivas voltadas para determinado grupo, definido a partir de características como raça, etnia, origem, condição social ou, ainda, de políticas de diversidade. Por isso, Weller (2007, p. 147) diz que é importante percebermos e compreendermos a dimensão política e "revolucionária" das cotas, pois foram anos de lutas travadas pelos movimentos sociais e entidades negras para alcançar essa conquista, sendo "essencial para que o ingresso na universidade por meio da política de cotas não se torne uma mera escolha no momento da inscrição para o vestibular".

No entanto, mesmo após a implementação dessas políticas de acesso, as universidades não têm garantido a permanência dos sujeitos que fazem parte desse processo e, não somente a permanência material (condiçóes de subsistência - transporte, alimentação e aquisiçáo de textos e livros), mas também as condiçóes de permanência simbólica, em que os alunos criam estratégias para permanecer, uma vez que "a trajetória acadêmica dos jovens na Universidade, sem uma adequada política de permanência, não é uma tarefa fácil” (REIS; TENÓRIO, 2009, p. 7).

Pensando nisso, o presente trabalho busca analisar a seguinte questão de pesquisa: Como se constitui o processo de permanência de estudantes negros da Universidade Estadual do Sudoeste da Bahia (UESB), de um dos cursos mais antigos e o segundo mais concorrido (Direito)? Diante dessa questão, o objetivo deste trabalho é analisar, a partir de entrevistas com estudantes negros desse curso, como se deu a sua trajetória até chegar ao ensino superior e quais as "estratégias" que utilizam para permanecer nesse meio.

Buscamos, ainda, compreender esta pergunta numa tentativa de (re) pensar os estudos neste campo, contribuindo de alguma forma e entendendo como se dá esse processo de estudantes negros dos meios populares até a chegada ao ensino superior, bem como os desafios que enfrentam diariamente para continuar estudando, principalmente por se tratar de um curso táo concorrido e que exige muito de cada um deles.

\section{Abordagem metodológica}

A presente proposta de pesquisa ancora-se numa perspectiva qualitativa, justificada, no caso específico do nosso estudo, por: a) ênfase no 
processo construído; b) construção de dados a partir do contato com os sujeitos a serem entrevistados.

Assim, pensando numa abordagem qualitativa de pesquisa, de forma sintética, Lüdke e André (1986, p. 13), apoiando-se em Bogdan e Biklen, afirmam: "A pesquisa qualitativa [...] envolve a obtenção de dados descritivos, obtidos no contato direto do pesquisador com a situação estudada, enfatiza mais o processo do que o produto e se preocupa em retratar a perspectiva dos participantes".

Para Minayo (1994), a pesquisa qualitativa explicita, em seu desenvolvimento e no interior da análise, elementos subjetivos e objetivos, sentidos, significados, valores, fatos, conflitos, ordens, contradiçóes, principalmente, as vozes e os sujeitos que dela participaram, voltando-se a um nível de realidade que não pode ser mensurável, controlado, reificado, mas compreendido em processo, sobretudo. Utilizando-nos das palavras da própria autora, diríamos:

Trabalha com o universo de significados, motivos, aspiraçóes, crenças, valores e atitudes, o que corresponde a um espaço mais profundo das relaçóes, dos processos e dos fenômenos que não podem ser reduzidos à operacionalização de variáveis (MINAYO, 1994, p. 22).

Dessa forma, com a intenção de analisar o acesso e permanência de estudantes dos meios populares no ensino superior, entendemos, de antemáo, que precisaríamos nos aproximar de uma abordagem teórico-metodológica capaz de possibilitar, por exemplo, a realização de entrevista, dialogando com os sujeitos envolvidos. Pensando nisso, as desenvolvemos na perspectiva da história oral, que segundo Thompson e Oliveira (1992, p. 22) "pode certamente ser um meio de transformar tanto o conteúdo quanto a finalidade da história", pois é por meio dela que as pessoas procuram compreender as "mudanças" e transformaçóes que passam/passaram em sua própria vida.

Entende-se, portanto, que a história oral possibilita compreendermos contextos e histórias diversificadas, dando voz a diferentes sujeitos, tornando-se assim uma atividade democrática, já que nos antepassados as pessoas que tinham "a voz" eram as que detinham o poder político e econômico. Poderemos então construir a história a partir das próprias palavras dos sujeitos, levando em consideração suas experiências de vida, 
nos atentando em saber como se deu a trajetória dos entrevistados durante o seu período de escolarização até a chegada à Universidade, tendo como base uma pesquisa desenvolvida por Amorim (2007), que buscou conhecer e identificar os sujeitos a partir de entrevistas realizadas.

A seguir, algumas questóes que nortearam o roteiro de entrevista com os sujeitos participantes e que colaboraram para o desenvolvimento deste estudo: aspectos socioeconômicos dos estudantes; identificaçáo dos seus projetos de estudos ao longo do processo educacional; tempo que levaram para concluir o ensino fundamental e médio e de qual rede de ensino advêm; de que maneira a família e outras redes de apoio contribuíram no processo de ascensão social; qual a escolaridade dos pais; se já participaram de cursinho pré-vestibular e como foi; se ingressaram no ensino superior pelo sistema de cotas e o que pensam sobre as açóes afirmativas da Universidade; se já sofreram algum tipo de preconceito; quais as estratégias que utilizam para "permanecer" no meio acadêmico; se possuem alguma bolsa/auxílio; se já pensaram em desistir do curso e quais os seus planos para quando terminar a faculdade.

\section{Discussão teórica}

Para entender como foi se constituindo as políticas públicas de ações afirmativas em nosso país, através dos movimentos negros em busca de políticas de "compensação" (como as cotas para o ensino superior), faremos uma imersão em bases teóricas que sustentaráo este trabalho, apresentando concepçóes e tipologias adotadas por pesquisadores e estudiosos.

No Brasil, a implementação de políticas públicas de ações afirmativas se deu somente a partir do processo de redemocratização do país, " quando diferentes grupos e organizaçôes sociais, antes silenciados pelo regime autoritário, passaram a demandar direitos abertamente" (DAFLON; FERES; CAMPOS, 2013, p. 306-307), assim sendo, as políticas afirmativas foram, inicialmente, propostas por movimentos sociais que lutavam pela inclusão de determinados segmentos da sociedade, aos quais foram, historicamente, negados seus direitos.

A política de ação afirmativa, segundo Salvador (2011, p. 39),

tem que agir em várias esferas da sociedade, com múltiplos objetivos, que vão além de uma proposta de inclusão social. $\mathrm{Na}$ verdade, é uma política que inclui nas áreas mais importantes 
para a integração social, como a educação e o mercado de trabalho, além de lidar com complexas questóes sociais da atualidade, como a desigualdade, a diversidade ou a discriminação.

E é por isso que essas políticas de açóes afirmativas têm grande importância para a sociedade brasileira, uma vez que o seu caráter "transformador" ficou conhecido após a implementação da política de cotas nas universidades, causando um grande impacto na sociedade, pois possibilitaram através disso as discussôes, reflexôes e questionamentos sobre o que até então era "desconhecido" por todos.

Assim sendo, as ações afirmativas, já citadas anteriormente, são concebidas como "políticas que visam, sobretudo, a tratar os indivíduos em condiçôes de igualdade, independentemente de sua cor, raça, sexo, geração, origem nacional, opção religiosa, orientação sexual, dentre outras características" (VIEIRA; MEDEIROS, 2012, p. 197), recaindo, entâo, sobre a materialização da igualdade, permitindo oportunidades iguais para todos, mas para que isto aconteça o Estado precisa se posicionar para que haja a garantia dessa igualdade.

Com relação às políticas de ação afirmativa no ensino superior, as Universidades públicas do Rio de Janeiro foram uma das primeiras a adotar as cotas para candidatos - oriundos da rede pública de ensino, negros, pessoas com deficiência e integrantes de minorias étnicas - aos cursos oferecidos, quando o Governador do Estado aprova a Lei Estadual $\mathrm{n}^{\circ}$ 3.524, de 28 de dezembro, reservando 50\% das vagas de todos os cursos de graduação a esses candidatos, causando grandes polêmicas na sociedade brasileira, pois as universidades federais, estaduais e particulares, começaram a adotar políticas de ação afirmativa. Assim, em respostas às críticas que foram surgindo, as Leis estaduais 4.151 de 2003 e 5.074 de 2007 alteraram a proporção de distribuição de vagas, sendo definidos $20 \%$ para alunos oriundos da rede pública de ensino, 20\% para candidatos negros e $5 \%$ para pessoas com deficiência ou indígena, tendo que atender ainda ao critério de carência socioeconômica. Por mais que as universidades estaduais tenham engendrado o assunto sobre as cotas, as universidades federais avançaram nesse processo, uma vez que "Entre as 70 universidades públicas que hoje adotam essas medidas, de um total de 96, são estaduais 44\% e federais, 56\%" (DAFLON; FERES; CAMPOS, 2013, p. 308).

No que se refere às discussões favoráveis ou não às quotas étnicas, Estácio (2013, p. 2-3) diz: 
[...] as políticas de ação afirmativa, em especial as quotas para acesso de negros e indígenas ao ensino superior, fixam-se nas pautas de discussões políticas, sociais e acadêmicas brasileiras. Debate esse, muitas vezes, caracterizado pela desinformação da sociedade brasileira, pela formaçấo de grupos de intelectuais, uns contrários outros favoráveis e a existência de pessoas, que acreditando na suposta democracia racial, fingem que nada está acontecendo.

Portanto, mesmo com os avanços em relaçáo à promoção dos direitos humanos, podemos ainda nos deparar com situaçóes de preconceito e discriminação contra mulheres, homossexuais, negros, indígenas, pessoas com deficiência etc., e é por estes motivos que esses grupos sociais são os que se destacam nas políticas de ação afirmativa, pois no decorrer dos tempos não tiveram como desfrutar de condiçôes mínimas de exercício da cidadania. A esse respeito, Vieira e Medeiros (2012, p. 197-168) dizem que "é possível afirmar que o racismo e a discriminação racial avançam no processo de desumanização e de não reconhecimento da cidadania dos negros [...]", portanto, os indivíduos precisam perceber que as "diferenças" não devem ser motivos de desigualdades, como costumamos ver diariamente.

Pode-se notar que a educação brasileira ainda deixa muito a desejar no que tange às discussóes e reflexóes dentro do contexto educacional sobre as relaçóes de gênero, que também é uma das causas que geram preconceito, discriminação e violência. Sobre esta questão, Weller (2007, p. 135) afirma que

é preciso realizar um esforço no sentido de integrar as políticas educacionais, uma vez que 'as desigualdades reforçam-se mutuamente' [sic] e o caminho para o enfrentamento das diferenças produzidas a partir das múltiplas desigualdades requer açôes articuladas e planejadas conjuntamente.

Pois no país em que vivemos, os pobres são "responsabilizados" por sua condição social e a vida que levam, e os negros são "lembrados" pela mídia como criminosos, que causam a violência e é sobre esta questão que Parente et. al (2012, p. 156) dizem que "essas identificaçôes ocorrem porque somos uma sociedade que, desde o período escravocrata, hierarquiza as relaçóes sociais com base na cor da pele, atribuindo às pessoas negras características negativas [...]". 
É por estes motivos que se travaram lutas na busca pela implementação de Açôes Afirmativas no Brasil, sendo identificadas como políticas de açôes compensatórias e distributivas. A primeira tem caráter "reparatório", com vista a retificar injustiças e discriminaçóes cometidas contra os negros, mulheres e indígenas, em que lhes foram negados direitos no passado, e que ainda hoje insistem em permanecer, sendo uma forma de "resgatar dívidas históricas". A segunda tem uma função mais atual e está relacionada "com a necessidade de se promover a redistribuiçáo equânime dos direitos, benefícios, ônus, vantagens, riquezas, bens e obrigaçóes pelos integrantes de uma sociedade. É uma busca de justiça no presente, ante a discriminação vivenciada no dia a dia" (ESTÁCIO, 2013, p. 4). Assim sendo:

Ela trata da promoção de oportunidades para aqueles que não conseguem ser representados de modo igualitário, e dessa forma o Estado seria o responsável em redistribuir os benefícios aos cidadãos, de maneira a tentar compensar e eliminar as desigualdades que os preconceitos e as discriminaçóes efetuaram, e efetuam ainda, no presente. Tem-se assim, a adoção de políticas universalistas e complementares, com o fito de reduzir a desigualdade e a pobreza, e mesmo que não utilize $\mathrm{o}$ aspecto racial, devem reconhecer a discriminação de raça e etnia no Brasil (ESTÁCIO, 2013, p. 4).

A partir das discussóes levantadas no Brasil, sobre as Políticas Públicas de Açóes Afirmativas, em 2008, a Universidade Estadual do Sudoeste da Bahia (UESB), através da Resolução 36/2008, estabelece o Programa de Açóes Afirmativas na Instituição, definido pelas açóes de: sistema de reserva de vagas "combinadas" com quotas adicionais para todos os cursos de graduação da Universidade; Assistência Estudantil (permanência); e Integração com a Comunidade e Fortalecimento de Açôes Externas de Assuntos Comunitários por meio de projetos e açóes que contribuam para a formação continuada dos profissionais de ensino e apoio institucional aos cursos pré-vestibulares comunitários e populares.

Consta ainda no Art. $2^{\circ}$ desta Resoluçáo que:

Art. $2^{\circ}$ - O Programa de Açóes Afirmativas da UESB consistirá em medidas especiais de discriminação positiva, com o objetivo de contribuir para a eliminação das desigualdades historicamente acumuladas, garantindo oportunidades de 
acesso e permanência aos segmentos sociais sub-representados, em decorrência de perdas provocadas pela discriminação e marginalização social por quaisquer motivos.

Portanto, foi instaurado, a partir da Resolução no 37/2008, o sistema de reserva de vagas e quotas adicionais no processo seletivo para todos os cursos de graduação da Universidade, num total de 50\% distribuídos nas categorias: $15 \%$ para estudantes que comprovem procedência de, no mínimo, 7 anos de ensino na Rede Pública e, dessa porcentagem, 35\% do total das vagas foram destinadas a estudantes que se autodeclararam negros. Assim, consta neste documento/Resolução CONSEPE:

\begin{abstract}
Art. $2^{\mathbf{o}}$ - Instituir, de forma complementar e cumulativa, a título de quotas adicionais, uma vaga para cada curso de graduação da UESB e em cada turno, para cada um dos seguintes segmentos sociais: indígena, quilombolas e pessoas com necessidades educativas especiais, mediante a apresentação de laudos antropológicos ou certidáo de registro fornecidos pela Fundação Nacional do Índio - FUNAI e Fundação Cultural Palmares; e laudos médicos que atestem a existência de suas necessidades educativas especiais, respectivamente.
\end{abstract}

Assim, após a implementação do sistema de reserva de vagas e cotas adicionais da UESB para todos os cursos de graduação, torna-se necessário que os sujeitos que tiverem optado pelo ingresso através dos segmentos indígena, quilombola e necessidades educativas especiais, deverão apresentar, no ato da matrícula, toda a documentação necessária para ocupar as vagas, sendo um critério de desclassificação, caso o candidato não esteja com essa documentaçáo. Já as declaraçóes quanto à procedência, sendo de Escola Pública e etnia, ocorrem durante o ato de inscrição do candidato.

Ainda nesta Resolução, no Art. $8^{\circ}$, é concedida a isenção da taxa de inscrição no vestibular, para aqueles que optarem pelo sistema de reserva de vagas ou quotas adicionais, para os oriundos de cursos pré-vestibulares comunitários e populares que tenham a comprovaçáo e aqueles que cursaram o ensino em Rede Pública, correspondendo a $5 \%$ do total de inscritos pagantes no ano anterior.

No Art. $6^{\circ}$ deste documento, diz-se que este Programa de Açóes Afirmativas de acesso estará em vigência durante 15 anos, havendo um acompanhamento anual pelo Comitê Gestor e que, a cada 5 anos, serão feitas 
avaliaçóes pelo CONSEPE, pensando em aperfeiçoar a implementação desta proposta na Universidade.

$\mathrm{Na}$ Resolução No 11/2008, é estabelecido o Programa de Assistência Estudantil que tem como objetivo contribuir para a garantia da permanência e conclusão dos alunos dos cursos oferecidos, mas para isso, os estudantes deverão comprovar carência econômica e social, segundo os critérios adotados pela Instituição.

Este Programa foi instaurado com a intenção de contribuir para a garantia da permanência e conclusão dos cursos, viabilizando a igualdade de oportunidades aos estudantes da UESB. Para tanto, foi definido que houvesse um sistema de avaliação quantitativa e qualitativa dos programas e projetos de assistência estudantil, analisando as relaçóes entre assistência e evasão, assistência e rendimento acadêmico. Assim, foi definido Subprogramas de assistência, com áreas e prioridades estratégicas, sendo elas: Permanência (moradia estudantil, alimentação, transporte, creche e atendimento à saúde); Desempenho Acadêmico (acompanhamento psicopedagógico, projetos de inclusão digital e ensino de línguas, eventos educativos etc.); Cultura, lazer e esporte; Assuntos da juventude (iniciativas de orientação).

\section{Análise dos dados}

As trajetórias de vida dos estudantes, construídas a partir de suas histórias de vida evidenciam os aspectos subjetivos da vivência de cada um, dentro de um sistema de valores e de representaçóes que deixam clara a importância da construção de um projeto de vida que envolve a universidade como meio de ascensão (BIGOSSI, 2007, p. 3).

Sendo assim, vamos pensar esse "projeto de vida" como sendo algo construído através das relaçôes familiares que se estabelecem, como também do seu próprio empenho na busca por tornar-se sujeito da sua própria história, e por ascender-se socialmente, considerando que estar na universidade é uma "alternativa" para sair da condiçáo em que se encontra e buscar seu espaço no mundo.

Através das entrevistas com os sujeitos que se dispuseram a contribuir para a pesquisa, buscamos conhecer os seus percursos de escolarização até a 
entrada na universidade. Sendo assim, analisaremos a seguir, as trajetórias escolares dos quatro estudantes entrevistados: Cleiton, Ariana, Edivânio e Jamilson, tomando como base a influência da família-escola, bem como seu empenho por ascender-se socialmente, além de questóes como o ingresso na universidade e os meios que utilizam para manter-se nesse espaço.

Dos quatro entrevistados, apenas um teve a oportunidade de estudar até o ensino fundamental I em Rede Particular, e no ensino médio estudou no Colégio da Polícia Militar, que é muito bem conceituado, mas os outros três sempre estudaram em escola pública e buscavam outras formas de "reforçar" os estudos em casa, com grupos de estudos, ou até mesmo através de cursinho, uma vez que todos eles apontaram para o fato de o ensino público não lhes dar as condiçóes necessárias para o ingresso no ensino superior, se comparado aos jovens que tiveram melhores oportunidades, mesmo que tenham tido uma trajetória de bons resultados durante a educação básica, não é suficiente.

Nas falas dos sujeitos, todos se referem a alguém que os incentivou a buscar um ensino superior, mesmo que não tenha partido dos pais. Cleiton, por exemplo, os seus pais não concluíram os estudos e, segundo ele, não tinham a noção da importância que era estar fazendo faculdade, então quem o incentivou foi a sua madrinha e a filha dela por quem ele tem a maior admiração e respeito. Relacionando essa fala de Cleiton com o que Bourdieu (2008, p. 68) discute sobre o capital social, e consequentemente sobre essa "rede de relaçóes", percebemos que a mesma nada mais é que:

[...] o produto de estratégias de investimento social consciente ou inconscientemente orientadas para a instituição ou a reprodução de relaçóes sociais diretamente utilizáveis, a curto ou longo prazo, isto é, orientadas para a transformação de relaçóes contingentes, como as relaçóes de vizinhança, de trabalho ou mesmo de parentesco, em relaçóes, ao mesmo tempo, necessárias e eletivas, que implicam obrigaçóes duráveis subjetivamente sentidas (sentimentos de reconhecimento, de respeito, de amizade etc.) ou institucionalmente garantidas (direitos).

No caso de Ariana, que obteve melhores condiçóes de estudo que Cleiton, - pois teve a oportunidade de fazer um mês de "auláo" preparatório para o vestibular no Sêneca (um dos cursinhos mais bem-conceituados de Conquista), - ela sempre teve em mente que faria um ensino superior, 
pois a sua mãe também lhe influenciava a buscar isso, a ser independente. No caso de Edivânio, sua mãe, mesmo sem condiçôes de pagar uma escola particular, procurou uma das mais conceituadas para seu filho estudar, e segundo ele, a sua irmã, que já fazia faculdade, lhe influenciava para prestar vestibular para Medicina, mas acabou que ele não se identificou com a área e optou por Direito.

Nota-se, portanto, que cada um dos sujeitos entrevistados teve percursos de escolarização diferentes, mesmo que em algum momento tenham se cruzado, por exemplo, no caso de três deles terem estudado somente em escola pública e todos criticarem o ensino público como náo suficiente para ingressar na universidade, uma vez que eles estariam "despreparados" em vista daqueles que têm pais com condiçóes de pagar um ensino particular. Mas, mesmo com pais que não concluíram os estudos ou que concluíram somente o ensino médio, e não tendo a noção do quanto seria importante estar numa universidade, sempre os apoiaram na busca por seus sonhos; Bourdieu (2008, p. 42) diz, sobre esta questão, que "uma avaliação precisa das vantagens e das desvantagens transmitidas pelo grupo familiar deveria levar em conta não somente o nível cultural do pai ou da mãe, mas também o dos ascendentes de um e outro ramo da família [...]".

Dos quatro sujeitos, três são provenientes de outras cidades, portanto, tiveram que morar em Vitória da Conquista para estudar, ocasionando maiores gastos como estadia, transporte e alimentação. Ariana é a única que é de Conquista e mora com os pais (trabalhadores autônomos), que sempre batalharam - como ela mesma relata - para lhe dar uma ótima educação, por isso, no que se refere à sua família, Ariana diz que:

Na verdade, a família é essencial no sentido de que ela te dá condições principalmente na questão material. Se a família tem uma boa condição, ela irá te dar melhores condiçôes favoráveis também. Na verdade, a minha família é uma família [...] são trabalhadores autônomos, tanto a minha mãe quanto o meu pai, mas que sempre se sacrificaram para dar a melhor educação possível para mim e para os meus irmãos.

Os pais de Cleiton não foram diferentes, pois mesmo sua mãe sendo doméstica, e o seu pai pedreiro, e não tendo uma noção da importância de um ensino superior, como Cleiton mesmo diz, eles não hesitaram em ajudar seu filho, mesmo com aquele dinheiro "contado", uma vez que 
nunca fizeram questão de que ele e seus irmãos trabalhassem enquanto estudavam.

Jamilson, o último entrevistado, a todo o momento falava sobre a influência e apoio (simbólico e material) que sua família lhe deu e ainda lhe dá, justamente por ser de outra cidade e por ainda náo ter uma bolsa-auxílio dentro da universidade.

Pode-se dizer que existe a influência de variáveis econômicas e sociais, caracterizando, assim, o sucesso ou fracasso escolar, pois o sujeito poderá ser influenciado conforme a realidade em que está inserido, tornando-se a família de fundamental importância nesse processo. Bourdieu (2008, p. 41-42) diz que,

na realidade, cada família transmite a seus filhos, mais por vias indiretas que diretas, um certo capital cultural e um certo ethos, sistema de valores implícitos e profundamente interiorizados, que contribui para definir, entre coisas, as atitudes face ao capital cultural e à instituição escolar.

Ou seja, a herança cultural era tida como uma das grandes responsáveis pelas "taxas de êxito" dos sujeitos, mas, a partir de estudos realizados, pôde-se perceber que ocorreram mudanças significativas, uma vez que os sujeitos se tornaram "agentes efetivos" da definição de seus objetivos e "destinos" sociais, inclusive escolares, ou seja, a causa de sucesso ou fracasso de indivíduos de um mesmo grupo social deixa de ser somente por conta dessas variáveis sociais, econômicas e culturais.

A partir da implementação das políticas de acesso ao ensino superior, houve cada vez mais a presença de estudantes negros e pobres a cursos tão concorridos como o de Direito, por exemplo, e esses estudantes ficam conhecidos como aqueles que entraram somente por causa das cotas, tirando a oportunidade de outros, mas isso porque muitos ainda discordam dessa implementação, e os próprios sujeitos desse processo acabam náo se identificando como tal, por sofrerem preconceitos dentro da Universidade.

Com a Resolução no 11/2008 (Programa de Assistência Estudantil), a UESB passou a oferecer bolsa-auxílio como transporte, moradia e alimentaçáo (dentre outras coisas) para os estudantes, desde que os mesmos comprovassem carência econômica e social, de acordo com critérios estabelecidos, com vista a contribuir para a permanência dos sujeitos e, 
consequentemente, viabilizar a igualdade de oportunidades entre os estudantes. No que se refere a essa "ajuda", os entrevistados criticaram por haver poucas bolsas disponíveis e não beneficiar a todos, além da meritocracia em consegui-las. A maioria desses estudantes busca uma "saída" através do auxílio PRAE (Programa de Assistência Estudantil) e por não conseguir, começa a se engajar em grupos de pesquisa e bolsas de Iniciação Científica, Pibid e estágios (dentro ou fora da universidade), sendo algumas das estratégias que utilizam para ajudar nas despesas, pois os seus pais, sozinhos, não teriam condiçóes de bancar tudo, uma vez que os gastos são grandes, principalmente para aqueles que estão longe de casa.

Com relação às situaçôes em que sofreram preconceitos e racismo, Cleiton foi o que mais vivenciou em seu dia a dia (tanto dentro da universidade quanto fora dela), relatando diversos momentos em que isso aconteceu. Uma dessas vivências se deu na escola, durante o ensino médio, onde sua professora de Literatura apontou o dedo para as pessoas da sala - em sua maioria, negros, pobres e de bairros periféricos da cidade -, que nunca conseguiriam alcançar um ensino superior. Em seu percurso na universidade, ele diz que uma professora de Agronomia (curso que fazia antes) falou do seu cabelo, que na época estava grande, afirmando que ele estava se vitimizando, por isso Cleiton diz haver um racismo velado dentro da própria universidade. Filho (2013, p. 37), sobre essa questão, afirma que "nas escolas há uma discriminação explícita ou velada, mas sempre presente por parte de muitos profissionais da Educaçáo, assim como no sistema de Saúde e no ingresso e ascensão no mercado de trabalho".

Pereira (1996, p. 75) discute sobre as relaçóes raciais no Brasil, afirmando ser um país que enfrenta a pluralidade étnica e ambígua, e que por isso, vivemos em uma sociedade que descarta a história brasileira do que de fato foi o "verdadeiro racismo", no campo de crueldades, torturas físicas e extermínio de grupos étnicos, existindo certo discurso social que é contrário à prática, pois "tanto inibe manifestaçôes negativas na avaliação 'do outro' racial como estimula a apologia da igualdade e da harmonia raciais entre nós, chegando ao extremo da sociedade brasileira” (PEREIRA, 1996, p. 76), ou seja, ninguém admite em suas falas ter preconceitos, (re) afirmando com isso que o Brasil é um país "pacífico" de discriminação, e para isso, utilizaram a cultura negra (tâo diversificada) para mostrar a "face" harmoniosa e democrática do país.

No que se refere às açóes afirmativas, buscamos identificar durante as entrevistas se os sujeitos eram ou náo cotistas, e o que pensavam sobre 
a universidade, bem como a sua opinião sobre as ações afirmativas da universidade.

Cleiton diz ter entrado na UESB pelo sistema de cotas, e se posicionou de maneira bastante crítica, no que se refere à importância dessas políticas, considerando todo o marco histórico pelo qual os negros passaram, e que não são levados em consideração. Ariana também é cotista, e disse que enxerga o sistema de cotas como uma medida necessária, pois assim como Cleiton, ela fala que por mais que a maioria da população brasileira seja composta por negros, os mesmos ainda são a minoria nas universidades, mas que é possível sim, que eles estejam ocupando vagas nesse espaço. Sobre esta questão, Filho (2013, p. 32) diz ainda que:

A ação afirmativa não se caracteriza por privilégio ou construção de espaços de usufruto de condiçóes discriminatórias, mas é uma medida ou conjunto de medidas para garantir que grupos socialmente discriminados, historicamente sem acesso às condições de educação, renda, saúde e trabalho, e que não teriam condiçóes de competir no mercado, possam efetivamente partir de um patamar similar a de outras pessoas [...]. Assim, as açôes afirmativas também precisam ser as cotas, as reservas de vagas.

Edivânio, também cotista, fala do quanto é importante a igualdade material (que Ariana também comenta), uma vez que muitas pessoas têm mais oportunidades e prioridades que outras. Ele relata que quando estava no ensino médio, as pessoas lhe perguntavam se ele iria optar por cotas, e a maioria dessas pessoas (brancas) optariam (por conta da questáo da escola pública), mas principalmente porque consideravam que teriam maiores chances de ingressar na universidade, por "ser mais fácil" entrar por cotas. E Edivânio, assim como essas pessoas, não enxergava as cotas como uma política pública que contribuía para o ingresso de grupos menos prestigiados da sociedade e que havia toda uma questáo histórica, e de lutas, por trás disso, pois ele considerava simplesmente como a "concessão de fácil acesso à universidade". Nota-se com isso que a grande maioria dos estudantes que está no ensino médio, prestes a prestar vestibular, ainda pensa como Edivânio e desconhece o caráter "reparatório" das cotas, e todas as discussôes que envolvem as políticas públicas de ação afirmativa.

Jamilson, assim como todos os outros, entrou na universidade pelo sistema de cotas e diz considerar as açóes afirmativas como "um meio 
necessário para o ingresso de uma classe que é abastada na sociedade e que precisa ser vista, mas que esse sistema de cotas e as açóes afirmativas não precisariam se o sistema funcionasse como deveria”, ou seja, ele não discorda das açóes afirmativas, mas diz que se a escola pública funcionasse como a Rede Privada funciona - em se tratando de conhecimento -, assim como todos os entrevistados já haviam criticado a falta de preparo dos estudantes da rede pública, não precisaria de cotas, pois estariam todos no mesmo patamar, mas já que isso não acontece, as ações afirmativas são vistas como um meio para que se insira essa parte da sociedade, "a minoria", nas universidades (Jamilson); portanto, Ariana já tem uma visão mais "pé no chão" quanto à questão de melhorar a educação básica para não precisar das açôes afirmativas, pois considera as mesmas como uma maneira rápida de dar uma resposta a esses grupos socialmente discriminados, ao invés de esperar que seja "reformulada" toda a educação básica, para que o ensino público seja igual ao privado, pois essa é uma medida que demanda muito mais tempo, e para a nossa sociedade atual, necessitamos de respostas urgentes e imediatas.

Com relaçáo ao que os entrevistados pensam sobre a universidade, bem como estar nela, todos tiveram opiniôes e contribuiçóes diferentes, e isso é muito interessante, pois nos faz refletir sobre qual é, ou tem sido de fato, o papel da universidade no que se refere à formação desses sujeitos e o que os mesmos pensam sobre esse espaço como lugar de (des)construção do conhecimento.

Dos sujeitos entrevistados, dois criticaram a universidade, considerando que a mesma ainda reproduz muito do que a sociedade é, como um espelho e seu reflexo, "repetindo" muitos do modus operandi do racismo e opressóes, como Cleiton mesmo relata ter vivenciado diversas situaçóes de racismo por professores da própria universidade. Ariana diz que esperava um pouco mais de dinamicidade da universidade, pois há poucos espaços de interação, uma vez que considera o seu curso a mesma coisa que estar num "escoláo", por ser uma questáo muito tradicional.

Logo, foi possível perceber que a universidade, como espaço da construção do conhecimento, infelizmente ainda reproduz através dos próprios sujeitos que a compóe situaçóes de racismo, e não disponibiliza, muitas vezes, aos estudantes, a pesquisa e extensão, preocupando-se somente com o ensino, que no caso do Direito, é visto como algo muito tradicional, em que tudo acontece dentro da sala de aula, e muitos estudantes não têm a oportunidade de se engajar em algum projeto de pesquisa, ou em movimentos estudantis, que contribuem para a formação intelectual e política. 
Apesar disso, muitos desses estudantes encontram nas bolsas de IC ou projetos de extensão, uma maneira de manter-se nesse espaço, uma vez que suas famílias, sozinhas, não conseguiriam arcar com os gastos, que são muitos. Apesar das críticas, os sujeitos entrevistados não deixaram de considerar a importância do âmbito acadêmico para a formação e construção do conhecimento, bem como a oportunidade para uma ascensão social.

\section{Consideraçóes finais}

Conclui-se, a partir das análises das entrevistas com os sujeitos da pesquisa, que cada um deles possui a sua trajetória, mas que muitos carregam consigo vivências e opiniôes bem demarcadas, seja sobre a questão do racismo; da permanência na universidade; da influência da família; do papel da universidade na formação; das açóes afirmativas, dentre outras coisas que foi possível discutirmos. Com base nas análises, percebe-se também que

é altamente competitiva a disputa, náo somente no mercado de trabalho como entre candidatos que almejam uma vaga na universidade pública, pois cada um tem a sua história e o seu nível de conhecimento, que variam conforme o seu campo de possibilidades, restrito também por causa da cor (AMORIM, 2007, p. 18).

Sendo as cotas uma grande conquista para o ingresso dos negros no ensino superior, mas que apesar disso, as universidades não conseguem disponibilizar a "permanência" a todos os que precisam dela.

O papel da família, parentes, amigos, vizinhos, tios e avós teve muito destaque nas falas dos entrevistados, sendo de extrema importância influências como essas na vida desses sujeitos no que se refere a suas trajetórias e no processo de ascensão social, sendo a família a "fonte" primordial. Teixeira (2003, p. 244 apud AMORIM, 2007, p. 24) afirma que "São essas redes que estabelecem relaçóes de amizade e solidariedade entre pessoas e famílias de diferentes classes sociais e de diferentes identidades raciais apoiando, incentivando e mantendo projetos e trajetórias de ascensão”.

Cada um dos quatro sujeitos entrevistados nos proporcionou, através de suas falas, conhecermos um pouco mais das suas histórias/trajetórias de vida até o ingresso no ensino superior, permitindo dialogar sobre as diversas situaçóes em que passaram até alcançar esta etapa em suas vidas, que é 
apenas o primeiro degrau na busca pelo sucesso, e por ascender-se socialmente. Sendo assim, "as trajetórias apresentam aquilo que quase todos os universitários negros das camadas populares enfrentam para superar a desvantagem em relação às famílias de classe média e atingir o nível superior de ensino" (AMORIM, 2007, p. 77), considerando que esses sujeitos são negros e provêm de famílias de pais que, em sua maioria, não concluíram os estudos, mas que desejam e oferecem aos seus filhos melhores condiçóes de vida, fazendo tudo que está ao alcance deles, e permitindo que voem alto e se tornem sujeitos de sua própria história.

\section{Referências}

AMORIM, Andréia Maria da Cruz Oliveira. Cor e ensino superior: trajetórias e o sucesso escolar de universitários negros da UFMT. Cuiabá: EdUFMT, 2007. (Coleção Educação e Relaçôes Raciais, 10)

BIGOSSI, Fabiela. Estudo antropológico sobre as trajetórias e projetos de vida de estudantes universitários negros. VII RAM - UFRGS. GT 33 - Memória, Família e Relações Geracionais Coordenação: Ricardo Iacub (UBA, Argentina) e Maria Cristina Caminha de Castilhos França (Unilasalle, Navisual/UFRGS, Brasil), Porto Alegre, 2007.

BOURDIEU, Pierre. Escritos de Educaçáo. Maria Alice Nogueira e Afrânio Catani (organizadores). 10. ed. Petrópolis, RJ: Vozes, 2008.

DAFLON, Verônica Toste; FERES, João Júnior; CAMPOS, Luiz Augusto. Ações afirmativas raciais no ensino superior público brasileiro: um panorama analítico.

Cadernos de pesquisa, v. 43, n. 148. jan./abr., 2013.

Decreto Estadual no 7.344, de 27.05.1998. Conselho Superior de Ensino, Pesquisa e Extensão - CONSEPE. Resolução Consepe no 36/2008.

Decreto Estadual no 7.344, de 27.05.1998. Conselho Superior de Ensino, Pesquisa e Extensão - CONSEPE. Resolução Consepe n³7/2008.

Decreto Estadual no 7.344, de 27.05.1998. Conselho Universitário - CONSU. Resolução CONSU no 11/2008.

ESTÁCIO, Marcos André Ferreira. Dialogar com a diferença: escuta das vozes favoráveis e contrárias as quotas étnicas. 36a Reunião Nacional da ANPEd GOIÂNIA - GO - 29 de setembro a 2 de outubro de 2013. 
FILHO, Denildon Silva. Políticas de açáo afirmativa na educação brasileira. Jundiaí: Paco Editorial, 2013.

JULIO, Ana Luiza dos Santos; STREY, Marlene Neves. Negros e negras no ensino superior: singularidade para a permanência. Revista África e Africanidades, ano 2, n. 5, maio, 2009.

LÜDKE, Menga; ANDRÉ, Marli. Pesquisa em educação: abordagens qualitativas. 9. ed. São Paulo: EPU, 1986.

MADALENA, Thais Fernanda Leite Madeira. Relaçóes étnico-raciais: um percurso para educadores. São Carlos: EDUFSCAR, 2012.

MINAYO, Maria Cecília de Souza (Org.). Pesquisa social: teoria, método e criatividade. 13. ed. Rio de Janeiro: Vozes, 1994.

PARENTE, Regina Marques. et. al. Educação para as relações étnico-raciais na perspectiva dos direitos humanos. In: SILVEIRO, Valter Roberto; MATTIOLI, Érica Aparecida KauaKami; MADALENA, Thais Fernanda Leite Madeira. Relaçóes étnico-raciais: um percurso para educadores. São Carlos: EDUFSCAR, 2012.

PEREIRA, João Baptista Borges. Racismo à brasileira. In: MUNANGA, Kabengele. Estratégias e políticas de combate à discriminação racial. São Paulo: Editora da Universidade de São Paulo: Estação Ciência, 1996.

REIS, Dyane Brito; TENÓRIO, Robinson Moreira. Políticas públicas de acesso e permanência da populaçáo negra no ensino superior: um debate em curso. Anais do Encontro da ANPAE, 2009.

SALVADOR, Andréia Clapp. Açáo afirmativa na PUCC - Rio: a inserção de alunos pobres e negros. Rio de Janeiro: Editora PUC Rio, 2011.

VIEIRA, Paulo Alberto dos Santos; MEDEIROS, Priscila Martins. Ação afirmativa no Brasil e no mundo: notas para um debate em curso. In: SILVEIRO, Valter Roberto; MATTIOLI, Érica Aparecida KauaKami. Relaçóes étnicoraciais: um percurso para educadores. São Carlos: EDUFSCAR, 2012.

WELLER, Wivian. Diferenças e desigualdades na Universidade de Brasília: experiências de jovens negras e suas visóes sobre o sistema de cotas. Revista Política e Sociedade, n. 11, out., 2007. 


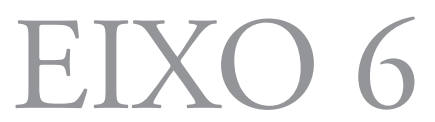

Povos indígenas e quilombolas: territoriedade e educação 


\title{
A PRÁXIS PEDAGÓGICA DOS PROFESSORES TUPINAMBÁS DE OLIVENÇA, ILHÉUS-BA
}

\author{
Marcinéia Vieira de Almeida Santos ${ }^{1}$ \\ Emília Peixoto Vieira ${ }^{2}$ \\ Flávia Cristina de Mello ${ }^{3}$
}

\section{Introduçáo}

Esta pesquisa ao tratar da educação escolar indígena inscreve-se como uma investigação decorrente das significaçôes que teve "a escola para os índios" na história do Brasil, correspondendo a funçóes e objetivos dos diferentes momentos políticos. Com a resistência e luta organizada dos povos indígenas no Brasil, a educação escolar indígena, que desde seu início serviu para impor as regras e normas da sociedade ocidental, passou a ser um elemento de revalorização e revitalização das culturas indígenas.

A partir das inúmeras experiências, diferenciadas em cada cultura na qual se inserem, as escolas indígenas mudaram de papel social: Não são mais um instrumento de opressão aos povos indígenas, e as comunidades conquistaram uma nova Escola, construída de forma a contribuir para as demandas nas aldeias. Com a consolidação desta nova escola, amparada pela Constituição de 1988, faz-se surgir um novo cenário com sujeitos, espaços e objetivos diferentes da educação escolar oferecida há séculos aos povos indígenas.

Nessa perspectiva, mudam-se as concepçóes de sujeito, mundo, educação e, também, as práticas pedagógicas no interior dessas instituiçôes escolares, atendendo aos princípios firmados pelo Movimento Indígena.

1 Discente do Programa de Pós-Graduação - Mestrado Profissional em Educação: Formação de Professores da Educação Básica - UESC, Ilhéus/Bahia/Brasil. E-mail: <marcineiaalmeida@hotmail.com>.

2 Docente do Programa de Pós-Graduação - Mestrado Profissional em Educação: Formação de Professores da Educação Básica; Departamento de Ciências da Educação - UESC, Ilhéus/Bahia/Brasil.E-mail: <emilcar128@hotmail.com>.

3 Docente do Departamento de Filosofia e Ciências Humanas - UESC, Ilhéus/Bahia/Brasil.E-mail:<flaviacdemello@yahoo.com.br>. 
Segundo Luciano (2013), a temática educação escolar indígena ainda é carente de estudos e pesquisas acadêmicas. Por ser um campo de análise recente, as experiências de educação escolar indígena soam de fundamental importância para a consolidação de açóes e políticas adequadas à nova conjuntura política e educacional que representa.

Do aspecto legal, a mudança inicia-se com a instauração de um novo paradigma para a educação escolar indígena, com a promulgação da Constituição Federal de 1988. A Lei de Diretrizes e Bases da Educaçáo Nacional no 9.394/1996, as Diretrizes Curriculares Nacionais para as Escolas Indígenas (BRASIL, 1999) que fixam diretrizes nacionais para o funcionamento das escolas indígenas focadas nos pressupostos pedagógicos da Interculturalidade, Especificidade cultural, Diferenciada por etnia e Bilíngue em Língua Portuguesa e Língua Indígena. Este arcabouço legal, somado ao Referencial Curricular Nacional para as Escolas Indígenas (RCNEI), elaborado em 1998, consolidam os principais parâmetros para orientar as açóes pedagógicas nestas novas escolas das aldeias.

O amparo legal suscitou discussóes e novas formas de resistência do Movimento Indígena. Essas discussóes ganharam autores que defendem as questóes relacionadas com essa nova escola indígena, incluindo nesses debates as questóes históricas, políticas e estratégicas para a efetivação da legislação. Entre esses autores citam-se: Luiz Donizete Benzi Grupioni (1995), (2006) e (2008); Gérsem dos Santos Luciano (2006) e (2013); Bartolomeu Meliá (1997), entre outros. Entre as principais discussóes sobre o novo modelo de escola estáo as concepçôes de ensino e de aprendizagem, professores e formação destes, a matriz curricular das escolas, adequadas às suas realidades culturais e a elaboração e utilização de material didático específico.

Os conceitos relacionados com o novo paradigma de escola necessitam de uma prática pedagógica que dê possibilidade de repensar a atuação dos educadores e as dificuldades/facilidades para a implementação dos princípios que embasam a educação escolar indígena.

As práticas pedagógicas das escolas indígenas no Brasil apresentam ora a possibilidade de inserção no mundo do branco, ora o resgate e permanência cultural. Esses dois papéis da escola indígena, aparentemente contraditórios, complementam-se na medida em que há a compreensão por parte de professores e lideranças, como destaca Cohn (2001), em pesquisa realizada com o Povo Gaviáo do estado do Maranhão, com a fala de um professor indígena "não há como deixar de ser índio aprendendo matemática e português" (COHN, 2001, p. 118). 
No entanto, é preciso relacionar as práticas ao contexto social em que estas se encontram, fazendo o estudante perceber-se como sujeito capaz de transformar-se e transformar o contexto de opressão que vive, ajudando-o a enxergá-lo desta forma. Para sustentar essa premissa, estamos fundamentados em Paulo Freire, principalmente na obra Pedagogia do Oprimido (FREIRE, 2005).

Nesse sentido, por fazer parte da comunidade indígena e corresponder a uma grande mudança conquistada e demandada por décadas pelo movimento indígena, esta nova escola só pode existir, se fundamentada nos princípios de interculturalidade, da especificidade, da diferenciação e do bilinguismo/multilinguismo, e é esta dimensão investigada, que será abordada neste texto.

Em avanço a estas reflexóes, este estudo soma ao princípio da interculturalidade o conceito de intercientificidade como um complemento conceitual para corresponder às angústias da pesquisa, já que diferentemente da interculturalidade, que é a troca de ideias entre grupos e indivíduos com origens étnicas, culturais, linguísticas, religiosas diferentes, a intercientificidade corresponde ao diálogo entre os sistemas de conhecimento tradicional e o sistema de ciência moderna, baseados nos estudos de Paul E. Little (2010), tão urgente para a prática pedagógica da escola indígena.

Desse modo, a investigação possui como objeto de estudo a prática pedagógica dos professores Tupinambás de Olivença/BA, e tem como questão problema: Em que medida os princípios da Escola Indígena apresentados pelo RCNEI são implementados, e se são condizentes com a prática pedagógica dos professores Tupinambás?

Tal questão apresenta como objetivo principal dialogar com os educadores Tupinambás sobre o processo de implementação e atendimento das demandas da prática pedagógica, conforme princípios que compóem o Referencial Curricular Nacional para as Escolas Indígenas. Especificamente objetiva-se: (i) identificar e discutir com os educadores os saberes culturais presentes no contexto Tupinambá de Olivença/BA; (ii) produzir subsídios para discussão, reflexão e revisão das práticas pedagógicas realizadas no Colégio Tupinambá de Olivença-BA.

A possibilidade de identificar e apresentar aos docentes as práticas pedagógicas e a relação destas com os princípios da escola indígena, com a finalidade de contribuir para a qualidade da educação escolar Tupinambá, tornou-se o principal motivo da pesquisa. 


\section{A institucionalizaçáo da Educaçáo Escolar Indígena e seus desafios}

A escola indígena como um lugar institucionalizado, em que acontece a relação de saberes entre conhecimentos de diferentes culturas e a possibilidade de divulgação para a sociedade nacional dos valores e saberes próprios dos povos indígenas (BRASIL, 1998) possui na prática docente a necessidade em conduzir e relacionar esses conhecimentos para que realmente aconteça a aprendizagem.

Essas questôes são consensuais no Movimento Indígena para que a educação seja conduzida por índios da comunidade. A esses profissionais são postos desafios para que aconteça uma educação na busca de excelência dentro do espaço institucionalizado, compreendendo que a experiência enquanto sujeitos político-culturais influenciará nos saberes dialogados, transformando tal experiência como fator principal de uma educação diferenciada.

O Movimento Indígena surgiu das organizaçóes e associaçóes dos povos indígenas, em âmbito nacional, na década de 1970, articulado em busca de soluçóes coletivas. Dentre os debates do movimento, a busca comum de processos educacionais específicos, a defesa dos territórios e respeito à diversidade linguística e cultural. Surge, então, um novo cenário e o que era historicamente imposto, nesse período, abre possibilidades para reivindicação das comunidades, como a reconstrução de novos caminhos pautados por paradigmas de respeito ao pluralismo cultural e de valorizaçáo das identidades étnicas. A escola indígena é constituída nesse contexto político, como um instrumento a favor da autonomia indígena e não mais uma instituição colonizadora a serviço do Estado.

Nas discussóes da nova Constituição Federal de 1988, surgiram as inquietaçóes das classes desfavorecidas, reivindicando deveres do Estado, dentre eles, os movimentos sociais e organizaçóes da sociedade civil. Entre tais movimentos estava presente também o movimento indígena.

Ao admitir a educação como um processo que ocorre de modos distintos e por meio de pedagogias e instituiçôes próprias em cada cultura, a Constituição reconhece aos índios no Art. 231 sua organização social, costumes, línguas, tradiçóes e no Art. 210, parágrafo segundo "a utilização de suas línguas maternas e processos próprios de aprendizagem" (BRASIL, 1988).

O direito a uma educação escolar diferenciada para os povos indígenas também se apresenta legalmente em outros documentos como a 
Convenção 169 da Organização Internacional do Trabalho (OIT) sobre Povos Indígenas e Tribais, promulgada no Brasil por meio do Decreto $\mathrm{n}^{\circ}$ 5.051/2004; a Declaraçáo Universal dos Direitos Humanos de 1948, da Organização das Naçôes Unidas (ONU); Declaração das Naçóes Unidas sobre os direitos dos povos indígenas de 2007; Lei de Diretrizes e Bases da Educação Nacional (Lei 9.394/1996), bem como por outros documentos nacionais e internacionais.

Para os povos indígenas, a escola que sempre foi o principal instrumento de destruição cultural, na Carta Magna, passa a ser o principal instrumento de reconstrução. O caminho da educação escolar indígena é, para tais povos, a esperança de conquista definitiva dos direitos da terra. (LUCIANO, 2006). Como adverte Meliá (1997, p. 21), "os povos indígenas mantiveram sua alteridade graças a estratégias próprias, das quais uma foi precisamente a ação pedagógica”.

Com a institucionalização da escola indígena, ganha-se também o modo de gestáo e começa a necessidade em legitimar a escola com características próprias (BRASIL, 1998).

A Lei de Diretrizes e Bases da Educação Nacional (LDBEN) institui a oferta de uma educação bilíngue e intercultural como dever do Estado. No Art. 78, assegura também a reafirmação de suas identidades étnicas e o acesso ao conhecimento das demais sociedades indígenas e não indígenas. Já no Art. 79, o apoio da União para o desenvolvimento de programas de ensino e pesquisa e objetivos que dispóe: o fortalecimento das práticas socioculturais, formação de pessoal para a educação nas comunidades indígenas, currículos e programas próprios, bem como elaboração e publicação de material didático específico (BRASIL, 1996). Com a demanda escolar vivenciada nas aldeias, foi publicado, em 1998, o Referencial Curricular Nacional para as Escolas Indígenas (RCNEI) que afirma:

Os momentos e atividades de ensino-aprendizagem combinam espaços e momentos formais e informais, com concepçóes próprias sobre o que deve ser aprendido, como, quando e por quem. A escola não deve ser vista como o único lugar de aprendizado. Também a comunidade possui sua sabedoria para ser comunicada, transmitida e distribuída por seus membros; são valores e mecanismos da educação tradicional dos povos indígenas (BRASIL, 1998). 
Entre os marcos legais que sustentam o RCNEI, destacam-se os princípios da escola indígena, construídos por professores indígenas em Manaus, em 1994, denominado de Declaração de Princípios. Tais princípios apresentam as características da escola indígena, currículo, formação de professores e as atribuiçóes dos entes federados nesses espaços (Idem, p. 27).

Através do RCNEI, a Educação Escolar Indígena ganha outras discussôes e novos documentos são criados, como por exemplo, as Diretrizes Curriculares Nacionais para a Educação Escolar Indígena na Educação Básica que possui como objetivo orientar as escolas indígenas no país (BRASIL, 2012).

Essas políticas propostas encontram desafios no interior das escolas indígenas, e principalmente na ação docente. Segundo Gomes e Silva (2002), são os profissionais da educação, que participam e desenvolvem as propostas político-pedagógicas, que devem inserir na prática educativa escolar o tratamento democrático às diferenças.

Por essa razão, o Movimento Indígena salienta que a educação seja realizada por índios da comunidade os quais participam de formaçóes, com organização de currículo próprio para atender a demanda dos professores em exercício (GRUPIONI, 2006). Pois a relação entre a formação de professores, os saberes, os valores, a cultura e as histórias de vida é um processo complexo que ultrapassa a questáo curricular.

Dessa forma, a escola, para os povos indígenas, é vista como um espaço onde a relaçáo entre os conhecimentos tradicionais e os novos conhecimentos poderão se articular de forma equilibrada para a construção de novas relaçóes igualitárias.

As escolas indígenas se propóem como espaços interculturais, onde a partir do debate se constroem novos conhecimentos e estratégias sociais sobre a situação de contato interétnico para valorização de cada povo indígena, como também garantir a participação cidadá a partir do acesso a conhecimentos e tecnologias da sociedade nacional. No cerne dessa questâo está o papel dos professores indígenas (SILVA, 2002).

Dessa forma, as reflexóes desse período justificam estudos que contribuam de forma crítica acerca da prática pedagógica dos docentes desde a educaçáo comunitária, vivenciada na aldeia de forma participativa nas demandas políticas da comunidade, à educação institucionalizada, capaz de promover a interculturalidade e a emancipação política a partir dos próprios conhecimentos. 


\section{Percurso metodológico da investigaçáo}

O estudo é realizado com dez professores Tupinambás que atuam na Creche e Núcleo Oka Katuana que pertencem ao Colégio Estadual Indígena Tupinambá de Olivença, Ilhéus-BA. O colégio está localizado na comunidade de Sapucaeira, a aproximadamente 16 quilômetros de Olivença, município de Ilhéus-Bahia. A instituição, denominada de escola sede, foi inaugurada em junho de 2006, através de várias mobilizaçóes dos Tupinambás e oferece as modalidades de educação infantil, ensino fundamental e ensino médio. Por não contemplar a demanda do número de discentes da região, a educação escolar também é oferecida nas comunidades chamadas de escolas núcleos. Entre esses núcleos está a Creche e Núcleo Oka Katuana, localizada na comunidade de Olivença, espaço da pesquisa.

O espaço foi escolhido em razão de oferecer a educação infantil e o ensino fundamental (diversidade de clientela e de ciclos de aprendizagem para enriquecimento das discussóes); dispor de estrutura e flexibilidade nos espaços e tempos para realização dos encontros; contemplar uma equipe de professores heterogênea (participantes de cursos específicos para atuar em escolas indígenas, concursados, contratados, com formação superior regular e ensino médio), bem como, da proximidade da pesquisadora com a comunidade indígena.

Diante da especificidade do nosso objeto de estudo, optou-se pela abordagem qualitativa, utilizando-se da pesquisa-açáo, numa vertente existencial defendida por Barbier (2007) e Paulo Freire (2005). O percurso metodológico da investigação seguirá fases, segundo a concepção de Barbier: Contrato, delimitação do problema de pesquisa e registro, em forma de espiral, ressignificando a práxis como uma necessidade do grupo durante todas as fases da pesquisa. As fases estão sendo organizadas e planejadas em forma de encontros com os professores para um diálogo de coleta de informaçóes que serão analisadas segundo as categorias freirianas: situaçôes limites, superação e ser mais. Esse tipo de pesquisa exige negociaçóes e decisôes coletivas, em que a reflexão e ação devem estar sempre presentes.

Estamos seguindo a vertente da pesquisa-ação proposta por Barbier (2007) numa concepção existencialista, acrescentando os fundamentos teóricos e metodológicos propostos por Paulo Freire na obra "Pedagogia do Oprimido" (2005). Tanto as concepçóes freirianas como as concepçóes da pesquisa-ação existencialista proposta por Barbier defendem a humanização 
do homem através da liberdade conquistada, a utilização do diálogo e a ação-reflexão-ação na busca das transformaçóes sociais.

Nesse sentido, trata-se de pesquisa qualitativa, utilizando-se de recursos dialógicos e, como complemento, os documentos oficiais, especificamente o Referencial Curricular Nacional para as Escolas Indígenas (RC$\mathrm{NEI}$ ), bem como produçóes científicas da área e os materiais produzidos pelos sujeitos durante o processo.

Por se tratar de pesquisa-ação, a coleta de informaçóes ocorre através do diálogo em forma de encontro com auxílio de alguns instrumentos que contribuem para a busca da resposta da questáo de pesquisa. Até o momento, já foram realizados cinco encontros com as professoras de forma coletiva e encontros com grupos pequenos em situaçôes estratégicas, como, por exemplo, nos cursos de formação e também no momento do planejamento coletivo. A realizaçáo dos encontros acontece em dois momentos distintos: a discussão do tema do encontro e o planejamento das aulas que ocorrem no cotidiano da escola, como instrumento para coleta de informaçôes, produção de novas discussóes e base para escrita do relatório coletivo. Somando-se ao plano de aula, temos ainda como instrumentos os relatórios das aulas, gravaçóes em áudio e vídeo, relatos orais e escritos, produçóes individuais e em grupos.

Quanto ao plano de aula, este foi apresentado com um quadro semiestruturado com os elementos característicos do plano de aula (cabeçalho identificador, duração das atividades, conteúdos, objetivos, eixos/áreas de conhecimento, procedimentos metodológicos, recursos e avaliaçáo). No entanto, após as discussóes descobriu-se que a estrutura do plano de aula não atendia a especificidade do Núcleo Oka Katuana. Em coletivo, os elementos do plano foram alterados para: objetivos, conteúdos, estratégias, recursos utilizados, parceiros e avaliação. O elemento "parceiros" foi incluído como elemento específico, para corresponder as atividades que dependem de outra pessoa e não apenas a professora. Às vezes, uma anciá é solicitada no núcleo para auxiliar ou, até mesmo, o porteiro se disponibiliza para acompanhar as atividades extraclasses ou em outras atividades que dependem da colaboração de um adulto, além do professor.

Juntamente ao plano de aula, os professores levam uma proposta para escrita do relatório, sobre a aplicaçáo do plano de aula construído no encontro. No encontro seguinte, são discutidos os relatórios das aulas aplicadas, as intervençóes do grupo, e assim, arquivadas no portfólio para escrita do relatório coletivo. 
O planejamento das açôes é realizado em três fases que dialogam em forma de espiral, segundo Barbier (2007), definidas como contrato, delimitação do problema a ser abordado e registro. Eis as características de cada fase:

1) Contrato - Refere-se ao estabelecimento do compromisso da instituiçáo e das negociaçôes entre os sujeitos que estão na condição de pesquisadores e pesquisados, considerando os objetivos da pesquisa, que devem ser apresentados na ocasião. Nesta fase também se define o local e o calendário de encontros; 2) Delimitaçáo do problema a ser abordado Esta fase se caracteriza pela apresentação do pré-projeto que foi elaborado, considerando apenas as primeiras impressóes do problema. Nela, é introduzida a discussão da abordagem teórica, que deve ser traduzida numa linguagem simples, acessível a todos. Esta fase é longa por se concentrar na reflexão sobre o objeto da pesquisa; e 3) O registro - É uma constante do processo, portanto, não é a última fase. Mas sua importância merece destaque. Cada registro, devidamente datado e catalogado, representa uma fase do diálogo e a soma deles representa a conclusão da pesquisa. As interpretaçóes parciais e a final estão nele contidas. A forma de divulgação destes dados deve ser discutida logo no início, no momento do Contrato (BARBIER, 2007).

A fase do Contrato aconteceu a partir de dois encontros: a visita ao espaço da pesquisa e apresentação do projeto à comunidade. Nos demais encontros, discutimos "os desafios", nessa pesquisa chamados de situaçóes limites, encontrados no diagnóstico da atuação pedagógica e a partir de então o planejamento dos encontros foi realizado. Esse planejamento sofre alteraçôes a cada encontro, já que surgem novas demandas no diálogo, tendo em vista a questão de pesquisa.

\section{Primeiras impressóes do desenvolvimento da pesquisa}

Com o objetivo de alcançar respostas a questão da pesquisa, o diagnóstico sobre a atuação pedagógica foi imprescindível para organizar um possível planejamento dos encontros. Para tanto, foi realizado um questionário com questóes abertas e uma conversa para que as professoras explicassem os principais desafios vivenciados na atuação pedagógica na escola Tupinambá. A partir deste, foi possível planejar as pautas iniciais dos primeiros encontros, sempre focando na busca de resposta sobre a 
implementação dos princípios apresentados pelo RCNEI na prática pedagógica Tupinambá e se esses atendem a especificidade de tal escola.

A priori, o desafio apresentado pelos professores foi a falta de acompanhamento pedagógico para atender à especificidade da escola indígena e como consequência a insuficiência de planejamento coletivo para discussão e reflexão das questóes pedagógicas. O planejamento coletivo acontece apenas uma vez por mês e atende todos os professores dos 18 núcleos que pertencem ao Colégio Tupinambá de Olivença, no mesmo dia. Os professores se dividem por turmas para planejar, porém a discussão e reflexão pedagógica não são realizadas em razão do tempo insuficiente. O planejamento é realizado pelos vice-diretores que se desdobram para atender a todos os professores, cada um com suas inquietaçóes.

O segundo desafio mais enfatizado foi a falta de material didático específico para escolas indígenas ou o desconhecimento dos que já foram publicados. Citaram ainda a falta de formação específica para todos os professores indígenas e atuação diferenciada na prática pedagógica dos professores que já receberam a formação e capacitação; o entendimento de questóes teóricas relacionadas com a atuação pedagógica, pois alguns dos professores que atuam não são formados em licenciaturas; a falta de sistematização de conteúdos para atender a educação diferenciada e intercultural.

Tendo em vista os principais desafios da prática pedagógica Tupinambá acima mencionados, os encontros foram planejados a partir de tais desafios representados como situaçóes limites, como uma das categorias freirianas, representadas nesta pesquisa.

Como apresentação quase que de forma unânime pelas professoras pesquisadas quando solicitadas a expor os desafios da prática pedagógica, o acompanhamento pedagógico e a insuficiência do planejamento coletivo tornaram-se inicialmente o debate mais urgente para exposição das primeiras impressôes.

O Estatuto do Magistério Público do Ensino Fundamental e Médio do Estado da Bahia, Lei no 8.261, de 29 de maio de 2002, Artigo 8º, destaca:

I - participar da elaboração da proposta pedagógica e do plano de desenvolvimento do estabelecimento de ensino;

II - elaborar e cumprir plano de trabalho e de aula, segundo a proposta pedagógica do estabelecimento de ensino; 
III - zelar pela aprendizagem dos alunos;

IV - estabelecer estratégias de aprendizagem e de recuperação para os alunos de menor rendimento.

Outro inciso do respectivo artigo que merece destaque para corroborar nas discussóes é o Inciso XI que trata: "analisar os resultados de desempenho dos alunos, visando a correção de desvios no Planejamento Pedagógico". Para o acompanhamento dessas atividades citadas no referido Artigo, há a necessidade de um coordenador pedagógico, cuja função é dar subsídio ao trabalho dos professores em favor da aprendizagem das crianças. Dessa maneira, seu papel está ligado às necessidades formativas dos professores. Logo, o coordenador pedagógico tem um papel importante na escola, pois ele é um formador e um articulador. Como formador precisa ter em mente que seu trabalho visa auxiliar o corpo docente a se aprimorar, ajudar o professor a lidar com seu próprio conhecimento, por isso deve entender de didática e metodologias. Como articulador, deve ainda articular as pessoas, os processos de aprendizagem e o projeto pedagógico da escola.

No entanto, apesar da Lei ter sido aprovada desde 2002, na prática, o estado da Bahia não realiza concurso para o cargo de coordenador pedagógico há mais de dez anos. Nas escolas convencionais "não indígenas", essa função fica distribuída nas mãos dos articuladores de área que, muitas vezes, não correspondem a função pedagógica de planejamento coletivo, entre outras funçóes que seriam de responsabilidade do coordenador pedagógico.

$\mathrm{Na}$ escola indígena Tupinambá não existe o articulador de área para o ensino fundamental II e ensino médio. A função de planejamento é realizada pelos vice-diretores, que não correspondem com êxito a função, devido ao grande número de salas nucleadas e de atendimento a todas as etapas da educação básica oferecidas pelo colégio. Essa situação torna-se ainda mais grave para a educação infantil e o ensino fundamental I, período que corresponde ao alicerce da educação básica.

Como o planejamento pedagógico é insuficiente, o processo de alfabetização também fica fragilizado devido à falta de reflexão e avaliação sobre a atuaçáo do professor em sala de aula, e principalmente da aprendizagem.

A falta desse "repensar" a prática na Escola Indígena Tupinambá contribui também para outros desafios da atuação pedagógica, enumerados de acordo com a realização do diagnóstico junto às professoras no 
primeiro encontro, a saber: falta de planejamento coletivo das aulas; material didático que não corresponde com a realidade; distorção idade-série; pouca interação família-escola-comunidade; ausência de cursos de formação para educação infantil, visto que há formaçôes para o ensino fundamental e não há para educação infantil; falta de união dos professores que influencia nas práticas pedagógicas da escola; déficits de aprendizagem e poucas capacitaçôes específicas.

No decorrer dos relatos orais e escritos dos encontros, é possível perceber que algumas atividades desenvolvidas pelas professoras Tupinambás contemplam, em parte, a efetivaçáo dos princípios apresentados pelo RCNEI. O momento do Poransy garantido na rotina desde os pequeninos da creche até os alunos do $5^{\circ}$ ano do ensino fundamental I é um exemplo de atividade diferenciada que contempla também o bilinguismo e a especificidade da escola indígena.

No entanto, há dois aspectos para serem destacados quanto à implementação dos princípios da Escola Indígena na Escola Tupinambá. Primeiro, a efetivação dos princípios ainda acontece de forma tímida e individualizada, já que os encontros coletivos são insuficientes para discussão da prática e planejamento das açóes. $\mathrm{O}$ segundo diz respeito à insuficiência desses princípios para atender as demandas da Escola Tupinambá atual, já que o povo Tupinambá não contribuiu na redação desses princípios propostos pelo RCNEI por uma discrepância cronológica entre a publicação do referencial em 1998 e o reconhecimento étnico Tupinambá em 2002.

Quanto ao segundo aspecto, nota-se o "acolhimento" como um princípio novo e específico da Escola Tupinambá, sendo implementado no cotidiano. A característica de ser comunitária da escola indígena que dialoga com os princípios da especificidade e do diferenciado, conforme o que está apresentado pelo RCNEI, não dá conta de corresponder às novas necessidades da escola indígena Tupinambá contemporânea. Em primeiro lugar, porque a Aldeia Tupinambá está localizada numa regiáo próxima à cidade. Segundo, porque os indígenas não possuem mais as mesmas ocupaçôes que garantiam suas respectivas sobrevivências décadas atrás.

De acordo às novas atribuiçóes, principalmente no modo de vida, a vivência dos Tupinambás modificou-se, sendo necessários novos arranjos no seio da família e da comunidade. Sendo assim, o "acolhimento" às crianças na escola Tupinambá é imprescindível. Tal acolhimento como princípio novo é notado na fala, no cuidado e na educação das crianças no dia a dia do espaço Tupinambá pesquisado, e náo apenas na escolarização. 
A implementação desse novo princípio, notado como resposta a demanda atual do referido povo, acontece como um fundamento acordado pelos professores que trabalham na Creche e Núcleo Oka katuana e que se pode afirmar como requisito indispensável para trabalhar no local, haja vista, por náo compreenderem a escola apenas como espaço de escolarizaçáo, mas também local de se sentir bem. Esta é a razão do significado em Tupy do nome Katuana: "Casa de paz e bem-estar".

Em linhas gerais, além da necessidade de implantar e implementar outro princípio, conforme descrito acima, os resultados parciais adquiridos através deste trabalho demonstram que os princípios para educação escolar indígena, apresentados pelo RCNEI e outros referenciais apresentados no decorrer deste texto determinados como política educacional para as escolas indígenas, são implementados de forma isolada pelos professores e não atendem as demandas específicas do povo Tupinambá de Olivença.

Os princípios constantes nos documentos, referências como resultados da conquista indígena durante séculos de resistência esbarram na prática pedagógica indígena com situaçôes surreais que impossibilitam a efetivação dos princípios propostos nos referenciais nacionais e, em especial, no RCNEI.

Percebemos no decorrer dos encontros que são graves os problemas encontrados para pôr em evidência o que estar determinado na $\mathrm{CF}$ de 1988, que consequentemente fizeram surgir os referenciais para a escola indígena. A falta de coordenador pedagógico para acompanhar o trabalho e o processo de aprendizagem das crianças e dos alunos indígenas e lhes garantir o diferenciado, o específico, a interculturalidade/intercientificidade e o bilinguismo é, para os professores Tupinambás, conforme resultados prévios da pesquisa, o principal fator que não permite a efetivação dos princípios na referida escola com excelência e que atenda toda a coletividade de professores. Contudo, é importante enfatizar que essa implementação acontece de forma individualizada, na atuação pedagógica do professor, que mesmo com todos os desafios encontrados, consegue contribuir para um novo significado da Escola Indígena Tupinambá.

Como resultado de uma correlação entre os aspectos legais, formativos e estruturais da profissão docente, a prática pedagógica do professor indígena náo pode ser culpabilizada pela insuficiência em atender aos princípios da escola indígena. $\mathrm{O}$ professor, neste caso, é apenas mais uma vítima das contradições entre as políticas educacionais e as condiçôes de trabalho oferecidas pelo Estado. 


\section{Referências}

BAHIA. Lei no 8261 de 29 de março de 2002. Dispóe sobre o Estatuto do Magistério Público do Ensino Fundamental e Médio do Estado da Bahia e dá outras providências. Salvador-BA, 2002.

BARBIER, René. A pesquisa-ação. Tradução de Lucie Didio. Brasília: Liber, 2007.

BRASIL. Constituiçáo Federal de 1988. Brasília, DF: Senado, 1988.

. Referencial Curricular Nacional para as Escolas Indígenas. Secretaria de Educação Fundamental. Brasília: MEC/SEF, 1998.

. Lei 9.394 de 20 de dezembro de 1996. Estabelece as diretrizes e Bases da Educação Nacional. Brasília, DF, 1996.

. Resoluçáo no 3 de 10 de novembro de 1999. Fixa Diretrizes Nacionais para o funcionamento das escolas indígenas e dá outras providências. Brasília: MEC, 1999.

. Decreto no 5.051, de 19 de abril de 2004. Promulga a Convenção no 169 da Organização Internacional do Trabalho - OIT sobre Povos Indígenas e tribais, Brasília-DF, 2004.

. Resoluçáo no 5, de 22 de junho de 2012. Define Diretrizes

Curriculares Nacionais para a Educação Escolar Indígena na Educação Básica. Brasília: MEC, 2012.

$\mathrm{COHN}$, Clarice. Escolas Indígenas no Maranhăo: um estudo sobre as experiências dos professores indígenas. In: LOPES DA SILVA, Aracy; FERREIRA, Mariana Kawall Leal. Práticas Pedagógicas na Escola Indígena. São Paulo: Global, 2001.

DECLARAÇÁO UNIVERSAL DOS DIREITOS HUMANOS. Adotada e proclamada pela resoluçáo 217 A (III) da Assembleia Geral das Nações Unidas, em 10 de dezembro de 1948. Disponível na Biblioteca Virtual de Direitos Humanos da Universidade de São Paulo. Disponível em: <www.direitoshumanos. usp.br>. Acesso em: abr. 2016.

\section{DECLARAÇÃO DAS NAÇÓES UNIDAS SOBRE OS DIREITOS DOS} POVOS INDÍGENAS. Aprovada pela Assembleia Geral da ONU, em 7 de setembro de 2007. Disponível em:< www.direitoshumanos.usp.br>. Acesso em: abr. 2016. 
FREIRE, Paulo. Pedagogia do Oprimido. Rio de Janeiro: Paz e Terra, 2005.

GOMES, Nilma Lino e SILVA, Petronilha Beatriz Gonçalves e. O desafio da diversidade. In: Experiências étnico-culturais para a formaçáo de professores. Belo Horizonte: Autêntica, 2002.

GRUPIONI, Luís Donisete Benzie; LOPES da SILVA, Aracy. A temática indígena na escola: novos subsídios para professores de $1^{\circ}$ e $2^{\circ}$ graus. Brasília: MEC/MARI/UNESCO, 1995.

GRUPIONI, Luís Donisete Benzi. Contextualizando o campo da formação de professores indígenas no Brasil. In: Formaçáo de professores indígenas: repensando trajetórias. Brasília: Ministério da educação, 2006.

"Olhar longe porque o futuro é longe: cultura, escola e professores indígenas no Brasil". Tese de Doutorado em Antropologia Social. Faculdade de Filosofia, Letras e Ciências Humanas. São Paulo: Universidade de São Paulo, 2008.

LITTLE, Paul E. Os conhecimentos tradicionais no marco da intercientificidade: os lugares dos conhecimentos tradicionais no mundo contemporâneo. In: LITTLE, Paul E. (Org.) Conhecimentos Tradicionais para o século XXI: etnografias da intercientificidade. São Paulo: Annablume, 2010.

LUCIANO, Gérsem José dos Santos. O índio brasileiro: tudo o que você precisa saber sobre os povos indígenas no Brasil hoje. Brasília: FUNAI, 2006.

Educaçáo para manejo do mundo: entre a escola ideal e a escola real no Alto Rio Negro. Rio de Janeiro: Contra capa; Laced, 2013.

MELIÁ, Bartolomeu. Açáo pedagógica e alteridade: por uma pedagogia da diferença. Mato Grosso: Secretaria de Estado de Educaçáo /Conselho de Educação escolar Indígena de Mato Grosso, 1997. (Anais da Conferência Ameríndia de Educação)

SILVA, Rosa Helena Dias da. Afinal quem educa os educadores indígenas? In: GOMES, Nilma Lino e SILVA, Petronilha Beatriz Gonçalves e. Experiências étnico-culturais para a formaçáo de professores. Belo Horizonte: Autêntica, 2002. 


\title{
RELAÇÓES ÉTNICO-RACIAIS: A INVISIBILIDADE DA CRIANÇA QUILOMBOLA NA PRODUÇÃO ACADÊMICA BRASILEIRA
}

\author{
Wesley Santos de Matos ${ }^{1}$ \\ Thiana do Eirado Sena ${ }^{2}$ \\ Benedito Eugenio ${ }^{3}$
}

\section{Introdução}

A produção científica no Brasil tem na Capes (Coordenação de Aperfeiçoamento de Pessoal de Nível Superior) sua principal agência de avaliação. Periódicos, livros e eventos passam por um processo rígido de avaliação e constituem parâmetros para as notas atribuídas aos Programas de Pós-Graduação (PPG).

Como nos ensinou Bourdieu (1983), a produção científica é construída num jogo de forças que irá constituir o campo científico, um verdadeiro mundo social. Para este autor, o campo científico é definido pelos agentes que o compóem, pois " [...] os pesquisadores ou as pesquisas dominantes definem o que e num dado momento do tempo, o conjunto de objetos importantes [...]" (BOURDIEU, 2004, p. 25).

Assim, é fundamental o mapeamento da produção acadêmica sobre determinadas temáticas, principalmente por nos permitir visualizar de que forma as lutas do campo científico têm eleito determinados objetos como legítimos e relegado outros, tendo em vista que com a aprovação da Lei $n^{\circ} 10.639 / 2003$ ampliou-se, consideravelmente, o quantitativo de pesquisas acerca das relaçôes étnico-raciais seja em espaços escolares ou não escolares.

1 Discente do Programa de Pós-Graduação em Relaçôes Étnicas e Contemporaneidade da Universidade Estadual do Sudoeste da Bahia.

2 Discente do Programa de Pós-Graduação em Relações Étnicas e Contemporaneidade da Universidade Estadual do Sudoeste da Bahia.

3 Docente da Universidade Estadual do Sudoeste da Bahia. Programa de Pós-Graduação em Relaçóes Étnicas e Contemporaneidade. E-mail: <beneditoeugenio@bol.com.br>. 
Estudos como os realizados por Gomes (2003; 2009; 2012); Silva; Assmann; Specht (2014); Baia Coelho e Silva (2013); Amorim; Baia Coelho (2014); Thijm; Baia Coelho (2014); Silva e Silva (2015); Caloti; Amorim (2015); Paula; Guimarães (2014); Silva (2011); Silva (2013); Freitas (2010); Moreira (2013), dentre outros, têm apontado para a importância e a necessidade da abordagem das relaçôes étnico-raciais no currículo, nas práticas pedagógicas das escolas de educação básica e nos cursos de formação docente.

Dessa forma, verificar de que forma a educação das relaçóes étnico-raciais vem sendo discutida nas pesquisas brasileiras da área de Educação é imprescindível. Partindo da afirmação de Morosini e Fernandes (2014), o Estado do Conhecimento é a identificaçáo, registro e categorização que levem à reflexão e síntese sobre a produção científica de uma determinada área, em um determinado espaço de tempo.

Tomando como relevante a afirmativa da autora supracitada, este trabalho tem como foco de análise a produção sobre a criança quilombola nos espaços escolares. Esta análise foi feita tomando como base os trabalhos apresentados nas cinco últimas reuniôes da Associação Nacional de Pós-Graduação e Pesquisa em Educação (ANPED), nos Grupos de Trabalhos (GTs): 3 - Movimentos Sociais, Sujeitos e Processos Educativos, 7 - Educação de Criança de 0 a 6 anos, e no 21 - Educação e Relaçóes Étnico-raciais.

A confecção deste Estado do Conhecimento carrega em si a necessidade de se desvelar como vem sendo (ou não) construído o conhecimento sobre a criança e, em especial, a criança quilombola. Até porque esse público tem um modo próprio de organização de ver e sentir o mundo que os rodeiam. Desde os anos 50, Florestan Fernandes (1979), em seu hoje clássico estudo sobre "As trocinhas do Bom Retiro", já nos alertava que é preciso uma imersão no mundo das crianças para poder compreender esse mundo que, frequentemente, passa despercebido aos olhos dos adultos.

Por outro lado, torna-se de fundamental importância analisar o que a academia tem produzido acerca da criança negra, tendo em vista que a discriminação racial experimentada pelos adultos também acontece na escola e com efeitos sutis, mas que marcam profundamente as crianças.

Sobre isso, Fazzi (2004, p. 90) aponta que

embora os mecanismos de transmissão de atitudes sejam similares para todas as crianças, o ambiente sociológico e psicológico 
e o pertencimento racial afetam a extensão dos sentimentos e a relação a eles. Assim, a transmissão de preconceito não é automática, e a existência de crianças mais ou menos preconceituosas ou não preconceituosas é possível.

Nesse sentido, torna-se fundamental que reflitamos atentamente para os modos como crianças articulam e modelam suas relaçóes, criam e recriam seus mundos, pois são atores quase que imperceptíveis aos olhos dos adultos.

Este artigo procura mapear a produção brasileira sobre a criança quilombola, em espaços formais de educação.

\section{Materiais e método}

Para a construção dos dados aqui analisados, preliminarmente foram feitas consultas à base de dados do Scielo e nos anais do II Simpósio Luso-Brasileiro de Estudos da Criança: desafios éticos e metodológicos, realizado em 2014. Em nenhuma dessas bases foram localizados trabalhos que evidenciassem o tema proposto para o estudo. Diante disso, direcionamos a pesquisa para as reunióes anuais da ANPED, por entendermos que essa Associação, ao congregar todos os programas de pós-graduação em Educação do país e por ter grupos de trabalho que abordem especificamente as crianças e as relaçóes étnico-raciais, pode ser um bom indicativo dos objetos privilegiados e, também, aqueles negligenciados pela produção acadêmica nacional.

Diante da situação que estava posta, fomos levados a utilizar a base de dados da ANPED e elegemos os GTs 3 (Movimentos Sociais e Educação), 7 (Educação da criança de zero a seis) e 21 (Educação e relaçóes étnico-raciais) como espaços da pesquisa. Assim, elegemos as cinco últimas reunióes nacionais da ANPED, a saber: $37^{a}$ reunião realizada em Florianópolis-SC, em 2015; 36 a reunião ocorrida na Universidade Federal de Goiás - UFG, em outubro de 2013; $35^{\text {a }}$ reunião realizada em Porto de Galinhas-PE, em outubro de 2012; 34a reunião ocorrida em Natal-RN, em outubro de 2011 e a 33a reunião realizada em Caxambu-MG, em outubro de 2010, como locus para a construção do corpus do presente texto.

$\mathrm{Na}$ pretensão de construir um estado de conhecimento que desse relevância à criança quilombola, foi efetuada a leitura flutuante (BARDIN, 
2011) com os resumos dos trabalhos publicados no Banco de Dados da Associação Nacional de Pós-Graduação e Pesquisa em Educação (ANPED). $\mathrm{Na}$ sequência, a fim de apreender mais elementos dos textos selecionados, realizamos a leitura completa dos trabalhos selecionados para a análise e que serão descritos, posteriormente, no presente artigo.

A partir das prioridades e decisóes tomadas na construção deste artigo, assumimos as categorias criança quilombola, educação quilombola e invisibilidade, como foco da análise. Articularemos as duas primeiras categorias na análise dos trabalhos encontrados que focam a temática ou aproximam-se da proposta aqui pretendida e a última categoria será discutida no tópico final deste texto.

\section{Resultados e discussáo}

Passamos, a seguir, a apresentar as discussóes acerca das crianças quilombolas efetuadas nos anais das Reuniôes Anuais - RA da ANPED selecionadas, conforme informado anteriormente.

$\mathrm{Na} 33^{a}$ edição da reuniấo nacional da ANPED, realizada em Caxambu- MG, em outubro de 2010, nos três GTs não foi encontrado nenhum trabalho que abordasse ou se aproximasse das discussóes das categorias elencadas para análise do corpus deste trabalho.

Ao analisar os anais da $34^{\mathrm{a}}$ edição da reuniáo nacional ocorrida em Natal-RN, em outubro de 2011, apesar das ausências da temática nos GTs 3 e 7, no grupo de trabalho 21 - Educação e Relaçóes Étnico-raciais aparecem dois trabalhos que se aproximam das categorias de análise. $\mathrm{O}$ primeiro, intitulado Educação Escolar Quilombola em Minas Gerais: Entre Ausências e Emergências, de autoria de Shirley Aparecida de Miranda - UFMG, problematiza a situação da implantação da modalidade da Educação Quilombola no âmbito das políticas públicas voltadas para a educação, porém não menciona nem aborda a criança quilombola como ator fundamental que vai usufruir dessa política de reparação social e reconhecimento por parte do Estado.

Além desta produção, encontramos também: Reflexóes em torno das relaçóes raciais no Brasil e da constituição da identidade de crianças negras na sala de aula com base na perspectiva dialógica, de autoria de Francisca de Lima Constantino - UFSCar. O trabalho traz reflexóes acerca das relaçôes raciais no Brasil ao longo de sua história, bem como relaciona 
suas influências históricas e sociais na construção da identidade negra do passado a atualidade. É resultado de uma pesquisa de mestrado e a autora conclui que o diálogo sobre as diferenças em sala de aula se faz importante na formação das identidades das crianças negras e brancas. Neste trabalho, a criança negra está presente, no entanto, a criança quilombola não aparece, até porque a pesquisa foi realizada em uma escola urbana da cidade de São Carlos-SP.

Analisando a $35^{\text {a }}$ edição, realizada em Porto de Galinhas-PE, em outubro de 2012, ratificamos as ausências da temática nos grupos de trabalhos (GTs) 3 e 7, enquanto que no GT 21, selecionamos dois artigos para verificação, tendo em vista a proximidade com o tema tratado.

O texto $O$ lúdico em uma comunidade quilombola: inspiraçóes para a educação das relaçôes étnico-raciais, de autoria de Maria Walburga dos Santos - UFSCar, tem como objeto o lúdico no interior da referida comunidade. Adota a definição dos quilombos contemporâneos e assume o lúdico como elemento da cultura e a cultura como objeto da História e da Educação. Crianças, jovens e adultos são os sujeitos da pesquisa à medida que seus depoimentos e experiências identificam e traçam o processo educativo do contexto de que fazem parte, para além da instituição escolar. A discussão proposta considera a diversidade como pauta elementar da área de Educação, dialogando diretamente com as proposiçôes de Educação das Relaçóes Étnico-raciais principalmente, ao apontar a urgência no Brasil do século XXI, em se romper com modelos que tendem a homogeneizar (e branquear) espaços e pessoas, além de padronizar o conhecimento. Neste trabalho, a criança aparece de forma integrada com os demais atores da comunidade quilombola, embora não haja uma ênfase na criança quilombola, tanto que não é utilizada a nomenclatura criança quilombola no corpo do texto.

Já na outra produção: A-Ian-Madê? Processo educacional de crianças quilombolas na escola da cidade, de autoria de Mille Caroline Rodrigues Fernandes - UNEB/PPGEDUC, é um recorte de uma pesquisa desenvolvida numa escola localizada no Baixo-sul Baiano, realizada com estudantes do quilombo de Boitaraca. O objetivo foi refletir sobre as dificuldades educacionais, enfrentadas por estas crianças e jovens, ao saírem da escola do "quilombo", no período da educaçáo fundamental II, para estudar na escola da "cidade". Na escola do "quilombo", durante o período da educaçáo infantil e ensino fundamental I, a professora da comunidade desenvolveu, em sua sala de aula multisseriada, espaços pedagógicos que 
propiciavam a valorização da memória, da oralidade e da arkhé, capaz de formar consciência individual e coletiva do grupo, mostrando caminhos didático-pedagógicos baseados na dinâmica do vivido/concebido.

Nessa perspectiva, ao saírem do seu meio sócio-cultural-histórico, durante o ensino fundamental II, e adentrarem numa escola, a qual a proposta curricular é baseada nos valores eurocêntricos, essas crianças e jovens experimentam o sabor amargo e nocivo do preconceito e da discriminação por serem negros e quilombolas. Assim, o texto discute o processo educacional na "cidade", um meio de exclusáo e silenciamento vivido pelas crianças e jovens ao saírem da escola do "quilombo". A autora se aproxima da discussão sobre criança quilombola, ao narrar as histórias e vivências das crianças em um espaço escolar fora da comunidade.

A 36 ediçáo da reunião nacional foi realizada na Universidade Federal de Goiás - UFG, em outubro de 2013. Assim como nas ediçóes anteriores conferidas, apontamos as ausências das discussóes nos GTs de números 3 e 7 , enquanto que no GT - 21, elencamos dois trabalhos que se aproximam da temática abordada neste trabalho.

Em Educação escolar quilombola: diálogos e interfaces entre experiências locais e a institucionalização de uma nova modalidade de educação no Brasil, de Kalyla Maroun - PUC-RIO, Suely Noronha de Oliveira - PUC-RIO e Edileia Carvalho - PUC-RIO, objetiva ilustrar o debate sobre a temática da educação escolar quilombola a partir de duas conjunturas diferenciadas e complementares: o processo de estruturação da política nacional para a Educação Escolar Quilombola e o contexto empírico de duas escolas quilombolas situadas na regiấo Sul Fluminense.

$\mathrm{O}$ processo de produção do texto da política nacional referente à educação escolar quilombola produziu impactos relevantes em extensão nacional. Dessa forma, compreender a educação escolar quilombola como categoria recente, ainda em desenvolvimento e em disputa, faz-se necessário para entendê-la enquanto um campo emergente da educação, que ainda tem muito a ser conhecido. $\mathrm{O}$ texto se atém à discussão das políticas públicas voltadas para Educação Escolar Quilombola, sem, porém, mencionar ou discutir os estudantes/crianças quilombolas.

A outra produção, Relaçóes étnico-raciais e educação infantil: ouvindo crianças e adultos, de autoria de Lucineide Nunes Soares - UEMG e Santuza Amorim da Silva - UEMG, investigou as relaçóes étnico-raciais nas práticas educativas engendradas com as crianças entre 0 e 6 anos de idade no contexto da educação infantil de uma escola pública do município de Teófilo 
Otoni-MG. Buscou-se descrever e analisar como a dinâmica e a organização dessas práticas, bem como as relaçôes estabelecidas entre crianças, crianças e adultos incidem nas configuraçóes identitárias das crianças negras; e identificar o que crianças e adultos dizem sobre estas práticas e relaçóes estabelecidas. O texto trata das relaçốes das crianças negras e adultos em geral, não fornecendo uma discussão onde apareça a criança quilombola.

$\mathrm{Na}$ edição mais recente da ANPED, a 37a, confirmamos a invisibilidade nos trabalhos sobre as discussóes da temática no GT - 3, enquanto que no GT - 7 selecionamos dois trabalhos, e no 21 um trabalho se aproximou da proposta de análise deste artigo.

No GT - 7, elencamos os seguintes trabalhos: Dimensão étnico-racial na educação infantil: um olhar sobre a perspectiva das crianças, de Eduarda Souza Gaudio - UFSC e Consideraçôes acerca da discriminação étnico-racial em crianças pequenas, de Sílvia Helena Vieira Cruz - FACED/ UFC.

O primeiro texto apresenta uma análise da pesquisa de mestrado da autora, que investigou as relaçóes sociais entre crianças quanto às diferenças étnico-raciais numa instituição de educação infantil pública. A investigação assumiu como base os estudos sobre Relaçôes Étnico-raciais na Educação Infantil no Brasil e as contribuiçôes dos Estudos Sociais da Infância, procurando dar visibilidade as diferentes expressóes que as crianças manifestam na relação com seus pares. Ao analisar essas relaçóes sociais das crianças, a autora percebe elementos que envolvem a dimensão étnico-racial, permeando e estruturando relações, reforçando de modo próprio muitos dos estereótipos e preconceitos existentes no contexto social que vivenciam. Após uma análise sobre esta produção, constatamos que não aparece na discussão a criança quilombola.

Já o segundo texto parte da presença da discriminação étnico-racial na educação infantil, da sua influência na construção da identidade das crianças e do pequeno número de trabalhos que investigaram esses processos em crianças, especialmente os que as ouviram diretamente. Evidenciamos que o texto não trata de criança quilombola, e sim de crianças negras em geral e dos processos de discriminaçóes a que elas estáo sujeitas.

Em seguida, analisamos o trabalho que selecionamos no GT - 21, Relaçóes raciais entre crianças na cidade de São Paulo: as pesquisas do Projeto Unesco, de Ana Cristina Juvenal Cruz - UFSCar. Este texto apresenta e discute a incursão teórica das pesquisas sobre criança e infância realizadas sobre os auspícios do Projeto UNESCO sobre as relaçóes raciais desenvolvido na cidade de Sáo Paulo. Isto é feito a partir de alguns documentos 
recolhidos do Fundo Florestan Fernandes que somados a uma metodologia genealógica estabelecem uma cartografia da pesquisa sociológica e histórica sobre as crianças e suas infâncias.

A partir da questão central a respeito dos aspectos que marcam a peculiaridade das relaçóes raciais brasileiras na década de 1950, encontra-se delineado um dos documentos que compuseram a pesquisa, denominado de Relaçôes entre crianças negras e brancas em parques infantis da capital. Este documento deriva de um estudo de campo sobre as condiçóes das crianças negras nos parques infantis da capital paulista. A proposta da autora restringe-se à análise desse processo, buscando restabelecer tais investigaçóes a uma gênese dos estudos sobre criança, infância que, desde logo, integre a ótica das relaçóes étnico-raciais. No presente trabalho, a invisibilidade da criança quilombola fica evidenciada.

Após efetivarmos as análises com os trabalhos elencados anteriormente e articulando-os com as categorias primárias de análise, Criança quilombola e Educação quilombola, aferimos que mesmo em todos os trabalhos, estando presente o descritor criança/infância/criança negra, a criança quilombola não tem o devido tratamento nas discussóes. Desta constatação emergiu uma terceira categoria que consideraremos para discutir as ausências, essa categoria que denominaremos de invisibilidade será abordada no tópico seguinte deste artigo.

\section{$4 \mathrm{~A}$ invisibilidade da criança quilombola na produção acadêmica}

Partindo das ausências notificadas nas buscas feitas na base de dados do Scielo e do Simpósio Luso - Brasileiro de Estudos da Criança: desafios éticos e metodológicos - Anais eletrônicos, demos relevância a uma categoria que se fez notória na construção deste trabalho a invisibilidade, ficou latente como a criança, e em especial a criança quilombola, não aparece nas produçóes acadêmicas, até mesmo nos eventos e meios que são destinados a esse público.

Constatada as lacunas na produção acadêmica, elegemos o Banco de Dados da Associação Nacional de Pós-Graduação e Pesquisa em Educação (ANPED) para fazer uma análise nos GTs - 3, 7 e 21, no entanto, ficou perceptível que os trabalhos nesses GTs pouco tratavam da temática que nos propusemos analisar. 
No GT 3 - Movimentos Sociais, Sujeitos e Processos Educativos, não conseguimos encontrar nenhum trabalho que revelasse um tratamento sobre o público analisado neste artigo, neste GT a invisibilidade foi completa, no GT 7 - Educação de Criança de 0 a 6 anos, apesar do título do GT ser específico para as produçóes de crianças, essa especificidade não se traduziu em trabalhos que colocassem em relevo as crianças quilombolas, apenas dois trabalhos se aproximaram timidamente sem, no entanto, tratar do tema em questão e no 21 - Educação e Relações Étnico-raciais, elencamos sete produçóes reunidas nas ediçôes analisadas, mas os artigos selecionados, também, não deram tratamento diferencial ao tema, passando tangencialmente sobre o mesmo, sem fazer referências à criança quilombola.

Diante da quase ausência de estudos sobre a criança quilombola, o trabalho de Silva (2011), nos ajuda a pensar algumas questóes sobre a temática deste artigo. De acordo com esta autora, as crianças quilombolas integram o grupo de crianças negras que convivem com o racismo. A autora chama atenção ainda para o preconceito triplo que a criança quilombola está submetida: primeiro por ser criança, depois por ser negra e, em seguida, por ser negra e quilombola. Nesse sentido aponta que

existe uma fronteira invisível entre crianças negras e crianças quilombolas, associada às concepções que a comunidade tem sobre as relaçôes sociais das crianças nos quilombos e o imaginário construído sobre as crianças do meio urbano. Uma fronteira que em determinadas circunstâncias também é tênue, precisamente quando as crianças quilombolas são inseridas no bojo das crianças negras, sem qualquer distinção (SILVA, 2011, p. 55).

Sobre o processo de visibilidade da criança quilombola, nos direciona no sentido de que:

[...] arriscamos afirmar que o conhecimento sobre o outro é capaz de produzir percepções com base nas tais singularidades das identidades, como por exemplo, o desconhecimento das singularidades na infância quilombola que orienta um sistema conceitual sobre identidades negras a fim de incorporar no mesmo grupo social todas as crianças negras. Assim, entender a visibilidade das crianças quilombolas é o caminho para a 
compreensão das representações e relaçóes sociais criadas no interior das comunidades, em que o sujeito criança pode existir sob concepções distintas e isto impactar na definição das crianças quilombolas nas políticas públicas do Estado. Ao passo que a visibilidade também propóe desconstruir estereótipos enraizados na sociedade e ressignificar o lugar das crianças quilombolas (SILVA, 2011, p. 59).

Compartilhando do pensamento da autora, percebemos que a construçáo dessa invisibilidade vai adquirindo forma quando o Estado, com seus mecanismos de recenseamento e controle, vai uniformizando em primeira instância as crianças e, em seguida, suas identidades, fazendo desaparecer as especificidades culturais e sociais de cada grupo.

A ausência de estudos sobre as crianças negras quilombolas, muito em função da recente entrada da sociologia nos estudos sobre a infância e da própria condição periférica das crianças de quilombos em estudos sociológicos, aliada à homogeneização de identidades híbridas e diversas (SILVA, 2011, p. 59).

Segundo Silva (2011), a homogeneização dos territórios engessa as políticas públicas por não conhecerem a localização exata dos quilombos e incorporam as comunidades como conjunto de comunidades rurais e, nesse processo, não articulam levantamentos a fim de identificar elementos culturais que venham corresponder com políticas a serem implementadas.

Um caminho possível que venha a contrapor essa invisibilidade é compreender que

a construção da visibilidade das crianças de quilombos passa pela necessidade de ter em consideração a relaçáo existente entre solidariedade, respeito e identidades quer seja nas comunidades, quer seja na relaçáo das comunidades com o Estado. Mas também, refere-se à necessidade de se desconstruir os modelos predominantes que historicamente caracterizaram-se, sobretudo, pela imposição e violência simbólica sobre grupos subordinados, em particular, o caso dos negros no Brasil (SILVA, 2011, p. 61).

Dessa forma, é fundamental que a academia, subsidiada pelo Estado, promova pesquisas voltadas às comunidades quilombolas, em especial as 
crianças quilombolas, de modo que essas pesquisas possam servir de base para a implementação de políticas públicas implementadas pelo Estado e direcionadas às comunidades quilombolas, de modo que essas políticas não sejam aleatórias, mas sim planejadas e direcionadas às especificidades de cada comunidade.

Conforme Silva (2011, p. 112), no que concerne a criança quilombola, o fato de ser criança, ser criança negra e ser criança do meio rural é a oportunidade de desenvolvimento de políticas transgressoras, inovadoras e que busquem nas diferenças os elementos necessários para a sua consolidação.

Não queremos que a visibilidade da criança quilombola seja uma dimensão meramente processual, burocrática ou acadêmica. Queremos instrumentos de transformação das relaçóes hegemônicas raciais na sociedade e que essa criança deixe de ser uma "qualquer criança negra" para o ocupar o lugar que por direito lhe é assegurado (SILVA, 2011, p. 112).

Se conseguirmos, enquanto pesquisadores, colocar em relevo esse grupo de crianças que tem um mundo próprio, formas peculiares de ver e sentir o mundo, valorizando as diferenças e as pluralidades tanto sociais quanto culturais, contribuiremos para superar essa invisibilidade na qual a criança quilombola está imersa, invisibilidade esta que vem sendo confirmada e reproduzida pela produção científica nos seus diversos campos.

\section{Consideraçóes finais}

Ao adentramos na temática proposta neste trabalho, qual seja, a de analisar a produção científica sobre a criança quilombola nos espaços escolares, a primeira constatação é a de que as crianças oriundas de comunidades remanescentes de quilombos não têm se constituído como objeto de investigaçôes por parte dos pesquisadores, mesmo dos investigadores da infância e/ou das crianças, seja com aportes da Sociologia, Antropologia ou Psicologia. Mesmo a Sociologia da Infância, muito influente ultimamente no Brasil, com diversos grupos de pesquisas dedicados ao tema, ainda não elegeu as crianças quilombolas como sujeitos importantes do seu programa de investigaçóes. 
Esta negligência se constitui na construção de uma invisibilidade quase que total da infância da criança quilombola, homogeneizando e retirando dela aquilo que a diferencia das demais, aqui compreendidas as especificidades étnicas e culturais. Ao analisarmos o material selecionado na ANPED, constatamos que há poucos trabalhos que se debruçaram sobre esses sujeitos sociais, o que demonstra a necessidade de pesquisas sobre as crianças quilombolas. No estado da Bahia, que apresenta o maior número de comunidades quilombolas reconhecidas e certificadas do Brasil, essa demanda é ainda mais urgente.

\section{Referências}

AMORIM, R.; BAIA COELHO, W.N. Política curricular e relaçóes raciais no Brasil: entre textos e discursos. Teias, vol. 14, p. 122-146, 2014.

SIMPÓSIO LUSO-BRASILEIRO DE ESTUDOS DA CRIANÇA: desafios éticos e metodológicos. 2, 2014, Rio Grande do Sul. Anais... Porto Alegre, 2014. Disponível em: <http://www.estudosdacrianca.com.br/site/ anaiscomplementares>. Acesso em: maio 2016.

BAIA COELHO, W.N.; COELHO, M.C. Os conteúdos étnico-raciais na educação brasileira: práticas em curso. Educar em Revista, v. 47, p. 67-84, 2013.

BAIA COELHO; WILMA, N; SILVA, Rosângela Maria N. Relaçôes raciais e educação: o estado da arte. Educar em Revista, v.47, p.67-84, 2013.

BARDIN, Laurence. Análise de conteúdo. Tradução Luis Antero Reto: Augusto Pinheiro. São Paulo: Ediçôes 70, 2011.

BOURDIEU, Pierre. O campo científico. In: ORTIZ, R. (Org.). Pierre Bourdieu: sociologia. São Paulo: Ática, 1983.

Os usos sociais da ciência: por uma sociologia clínica do campo científico. São Paulo: Ed. Unesp, 2004.

FAZZI, R. C. O drama racial de crianças brasileiras: socialização entre pares e preconceito. Belo Horizonte: Autêntica, 2009.

FERNANDES, Florestan. As trocinhas do bom retiro: contribuiçóes ao estudo folclórico e sociológico da cultura e dos grupos infantis. In: Folclore e mudança social na cidade de Sáo Paulo. Petrópolis: Vozes, 1979. 
FREITAS, Sandra R. Formaçáo continuada de professores da rede estadual do Paraná para o ensino da história e cultura afro-brasileira e africana. Dissertaçāo (Mestrado em Educação). Pontifícia Universidade Católica do Paraná, Curitiba, 2010.

GOMES, N. L. Educação, identidade negra e formação de professores/as: um olhar sobre o corpo negro e o cabelo crespo. Educaçáo e Pesquisa, v. 29, n. 1, p. 167-182, jan./jun. 2003.

Limites e possibilidades da implementaçáo da Lei no 10.639/03 no contexto das políticas públicas em educação. In: HERINGER, Rosana; PAULA, Marilene de. (Orgs.). Caminhos convergentes: estado e sociedade na superação das desigualdades raciais no Brasil. Rio de Janeiro: Henrich Boll Stiftung; Action Aid, 2009.

. Relações étnico-raciais, educação e descolonização dos currículos.

Currículo sem Fronteiras, v. 12, n. 1, p. 98-109, 2012.

MOREIRA, Josinélia S. A formaçáo de professores/as e a educaçáo multicultural no cenário da educaçáo de jovens e adultos. Dissertação (Mestrado em Educação). Universidade do Estado da Bahia, Salvador, 2013.

MOROSINI, Marília Costa. FERNANDES, Cleoni Maria Barboza. Estado do Conhecimento: conceitos, finalidades e interlocuçôes. Educação Por Escrito, Porto Alegre, v. 5, n. 2, p. 154-164, jul./dez., 2014.

PAULA, Benjamin X. de; GUIMARÃES, Selva. 10 anos da Lei Federal 10.639/03 e a formação de professores: uma leitura de pesquisas científicas. Educaçáo e Pesquisa, n. 40, v. 2, p. 435-448, 2014.

SILVA, Beatriz Caitana da. A construçáo da (in)visibilidade da infância quilombola: o papel do Estado e do movimento social. Dissertaçáo (Mestrado em Sociologia). Universidade de Coimbra, Coimbra, 2011.

SILVA, K.E.; SILVA, L.F. As questōes raciais na educação infantil: possibilidades e desafios em uma dimensão pedagógica. Simbiótica, v. 2, n. 1, p. 22-41, 2015.

SILVA, Giselda C. O estudo da história e cultura afro-brasileira no ensino fundamental: currículos, formação e prática docente. Tese (Doutorado em Educação). Universidade Federal de Uberlândia, Uberlândia, 2011.

SILVA, Glênio O. Arcabouço jurídico normativo pedagógico da Lei 10.639/03 na Universidade Federal de Uberlândia: avanços e limites. Dissertaçáo (Mestrado em Educação). Universidade Federal de Uberlândia, Uberlândia, 2013.

THIJM, F.E.A; BAIA COELHO, W.N. Um estudo das relaçóes raciais em teses e dissertaçóes brasileiras no período de 2004 a 2013. Cocar, v. 8, n. 16, p. 167-181, 2014. 


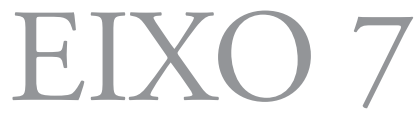

Movimentos sociais, associativismo e sindicalismo docente 


\title{
CONTRIBUTOS DA EDUCAÇÁO DO CAMPO PARA FORMAÇÃO DE SUJEITOS AUTÔNOMOS: UM ESTUDO NO ASSENTAMENTO LUIS INÁCIO LULA DA SILVA ${ }^{1}$
}

\author{
Altemar Felberg ${ }^{2}$ \\ Geovani de Jesus Silva ${ }^{3}$
}

\section{Introduçáo}

Em revisão literária, podemos perceber que o conceito de autonomia - que etimologicamente vem do grego autós (ele mesmo, por si mesmo) e nomos (lei, convenção, regra), que significa o poder de dar a si a própria lei - fora construído historicamente pelas diferentes características culturais, econômicas e políticas que configuraram as sociedades ao longo de sua trajetória, tendo sido refletido inicialmente pelos historiadores e filósofos gregos e ganhado destaque e notoriedade na modernidade com os estudos de Kant (1974).

Posteriormente aos estudos kantianos, diversos outros autores se debruçaram sobre a temática, abordando a autonomia numa perspectiva mais política e sociológica, a partir de um entendimento de que os conceitos de autonomia e participação social possuem tênue relação. Castoriadis (1991), Adorno (1984), Paulo Freire (1986), Marilena Chauí (1990), Bobbio (2000) e Amartya Sen (2008) são apenas alguns destes autores, dentre muitos outros.

1 Artigo elaborado a partir da dissertação de mestrado Autonomia e Desenvolvimento Comunitário no/do Campo: contradiçôes e consensos no Assentamento Luís Inácio Lula da Silva. O referido artigo enquadra-se no Congresso no Eixo Movimentos de luta pela terra e Educação do Campo.

2 Mestre em Ciências da Educação (Universidade Lusófona de Humanidades e Tecnologias - ULHT - Lisboa/PT). Professor da Faculdade Nossa Senhora de Lourdes - FNSL. E-mail: <felberg_imt@hotmail.com>.

3 Doutor em Educação pela Universidade Federal de Minas Gerais - UFMG, Professor adjunto da Universidade do Estado da Bahia - UNEB. E-mail: <geovanideporto@yahoo.com.br>. 
Para Castoriadis (1991), a autonomia conduz diretamente ao problema político e social da humanidade, posto que não se pode almejá-la sem desejá-la a todos, e cuja realização só pode conceber-se plenamente como empreitada coletiva. Esse entendimento é também defendido por Freire (1986) quando nos alerta de que mesmo quando nos sentimos mais livres, mais autônomos, se esta conquista não for utilizada a favor da coletividade, estaremos apenas exercitando uma autonomia individualista, no sentido do empoderamento pessoal.

Nesta mesma linha, Chauí (1990) nos diz que a autonomia é a posição do sujeito sócio-histórico-cultural que, por sua própria ação e vontade ética, é criador das leis e regras da sua existência social e política; o que na perspectiva freiriana tem a ver com o 'ser para si', onde num contexto histórico subdesenvolvido dos oprimidos, a autonomia está intimamente relacionada com a libertação. É justamente sob esta perspectiva que se pretende firmar este texto, reconhecendo a autonomia como defende Pereira, M. (2007), como um recurso capaz de livrar os indivíduos não só da heteronomia de processos opressores sobre as suas liberdades de escolha e de ação, mas também da miséria e do desamparo, da privação do exercício de um dos direitos sociais mais sagrados: a participação ativa e qualificada nos processos de discussão, formulação e usufruto efetivos das políticas de desenvolvimento.

O conceito de autonomia advém do sentido de participação política e social, a qual é considerada como uma das mais importantes medidas na avaliação do desenvolvimento "a liberdade de participação ou dissensão política ou as oportunidades de receber educação básica, são ou não são conducentes ao desenvolvimento" (SEN, 2008, p. 19), ideia corroborada também por Frey (2000), o qual defende que a autonomia apresenta-se como dimensão a ser considerada, seja nos indicadores, seja no ciclo das políticas públicas.

Para os autores, ter mais autonomia e agir com maior liberdade de pensamento e ação melhora o potencial das pessoas para cuidar de si mesmas e para influenciar o mundo - questóes centrais para o processo de desenvolvimento. E como conquistar ou potencializar essa autonomia? Aí que entra o papel da educação.

Na sua obra sobre pedagogia, Kant (1996) fala sobre a importância de a ação educativa seguir a experiência. A educação não deve ser puramente mecânica nem se fundar no raciocínio puro, mas deve apoiar-se em princípios e guiar-se pela experiência. A partir da pedagogia kantiana, 
podemos dizer que uma educação que vise formar sujeitos autônomos deve unir lições da experiência e os projetos da razáo.

Neste sentido, a temática da autonomia, que ganhou centralidade nos pensadores e na educação moderna, especialmente em Paulo Freire (1986) que a atribui um sentido sócio-político-pedagógico: autonomia é a condição sócio-histórica de um povo ou pessoa que tenha se libertado, se emancipado das opressóes que restringem ou anulam sua liberdade de determinação. E conquistar a própria autonomia implica, para Freire, libertação das estruturas opressoras - uma das bandeiras defendidas pelos educadores e educadoras da educaçáo do campo.

Náo é preciso estar no dia a dia das populaçôes que vivem no/do campo para notar o quadro de marginalidade e exclusáo em que se encontram, seja na esfera nacional ou local, delineado a nosso ver, principalmente, dentre outros fatores, pela ineficácia das políticas públicas, principalmente no que tange ao oferecimento de uma educaçáo de qualidade e libertária da dependência e alienação - base primordial para a conquista do poder, em suas várias dimensóes, capaz de promover e transformar a sociedade. Um poder, no sentido usado por Freire (1986), como um aumento da conscientizaçáo e desenvolvimento de uma "faculdade crítica"; um poder de "fazer" e de "ser capaz", bem como de sentir-se com mais capacidade para agir e desempenhar um papel ativo nas iniciativas de desenvolvimento.

Nesse contexto, há perspectivas que apontam que a restrição da autonomia dos atores sociais do meio rural elide as possibilidades desses grupos menos favorecidos em participar ativamente dos processos de discussão, formulação e usufruto efetivos de políticas de desenvolvimento local. Por outro lado, a autonomia construída a partir da expansão das capacidades individuais e coletivas, de refletir e decidir autonomamente sobre aquilo que é significativo e de valor para si e para seu grupo pode ampliar as possibilidades de exercício da cidadania, de luta contra as pressóes externas e de desenvolvimento.

Nossa defesa aqui, para além da educação como um direito e princípio libertador das heteronomias, é que não é mais possível conceber e aceitar o desenvolvimento sem pensá-lo atrelado à ideia de promoção da autonomia dos sujeitos e à ampliação de suas capacidades e liberdades fundamentais; sem a oportunizaçáo a estes da conquista do poder como o conhecimento que possibilita a percepçáo crítica da realidade e a reação frente às injustiças e desigualdades sociais; sem destacar a diversidade 
cultural e o respeito à diferença como importantes medidas de avaliação no processo desenvolvimentista; sem possibilitar que as populaçóes rurais marginalizadas consigam se descobrir e se assumir como capazes de protagonizar suas próprias histórias de desenvolvimento pessoal e social.

\section{$2 \mathrm{O}$ direito à educaçáo como instrumento de inclusão social}

O direito à educação, como um direito humano reconhecido e declarado, é relativamente recente e remonta ao final do século XIX e início do século XX. Historicamente, como nos aponta Cury (2002), o direito à educação, mais do que como uma exigência do mundo contemporâneo ligado aos processos de produçáo de bens de consumo e de inserção qualificada no mundo do trabalho, responde a valores da cidadania social e política, resultante náo da vontade dos governantes, mas da luta dos movimentos sociais.

No Brasil, especificadamente, o direito à educação é reconhecido desde 1934. A Constituição daquele ano o caracterizou como direito subjetivo público:

[...] direito de todos e deve ser ministrada pela família e os poderes públicos, cumprindo a estes proporcionar o acesso a brasileiros e estrangeiros domiciliados no país, de modo que possibilite o desenvolvimento eficiente de valores da vida moral e econômica da Nação, e desenvolva num espírito brasileiro a consciência da solidariedade humana.

Ainda que considerada a matéria nas Constituiçóes subsequentes, a de 1937 (Constituição do Estado Novo), a de 1946 (Constituição pós II Guerra Mundial) e a de 1967 (que acrescentou a unidade nacional e a solidariedade humana), a Carta Magna de 1988 é, dentre as nossas Constituiçóes, a que melhor discorreu e contemplou o reconhecimento de direitos e liberdades fundamentais, bem como a garantia para o seu acesso e exercício.

Desse modo, a partir de 1988, a educação consolidou-se enquanto um dos direitos sociais, de forma subjetiva e inalienável. Sua disciplina específica encontra-se no título relativo à Ordem Social, nos Artigos 205 a 214 da Carta Magna. Todavia, ainda que uma grande conquista, 
a Constituição não foi capaz de traduzir as necessidades e especificidades em educação dos sujeitos do campo. Apesar dos avanços na conquista de direitos, o quadro de exclusão com a consequente marginalização de indivíduos ainda é uma dura realidade brasileira e que precisa ser fortemente combatida. E nesse confronto é que precisa ser intensificada pelas políticas públicas, sociais e educativas, provocada pela Academia e pelos movimentos sociais organizados a prática sociocultural de disseminação dos direitos e das iniciativas de promoção da autonomia - um grito a favor da oportunização de sujeitos com melhores condiçôes de participar, igualitariamente, dos processos de desenvolvimento do nosso país, tal feito somente será possível, se houver a disseminação e a universalização da educação escolar de qualidade como um direito da cidadania, conforme destaca Cury (2002).

Para ter uma ideia, mesmo a Constituição Federal de 1988 tendo declarado o direito à educação como um dos prioritários de todos os brasileiros, independente da sua condição física, mental, étnico-racial, política e territorial, os povos do campo tiveram que, através dos movimentos sociais de luta pela terra, fazer valer tal direito, com ocupação, resistência e muita luta. Se formos comparar mais profundamente dados da educação no campo com a educação das cidades, veremos o quáo grande é o abismo que as separam, refletindo a desigualdade no nosso país.

Por isso, o enfrentamento ao silenciamento e ao esquecimento à questão da educação do campo é justamente a bandeira de luta dos militantes do movimento "Por uma Educação do Campo", conforme Miguel Arroyo, Roseli Caldart e Mônica Molina (2004).

Neste sentido, a privação da educação como um direito inviolável de todo o cidadão, sem qualquer distinção, é resultado, primeiro, da negligência do poder público, responsável pela triste realidade social apresentada no país, que não dá espaço ou oferece alternativas para o crescimento das classes menos favorecidas, ou até impede dessas buscarem e conquistarem a sua autonomia e, consequentemente, o desenvolvimento por meio da educação.

Os autores citados acima corroboram com esse entendimento ao destacar que o direito à educaçáo vem sendo negado à população brasileira do campo, historicamente, desde sempre. Enfatizam que apesar dos movimentos docente e pedagógico progressista do Brasil protagonizarem a história de luta pelo reconhecimento da educaçáo como um direito humano desde a década de 1980, os avanços conquistados até entấo náo repercutiram no 
campo. Afirmam que "[...] os homens e as mulheres, as crianças, os adolescentes, jovens, adultos e idosos do campo não estavam excluídos desse grito, porém não foram incluídos nele com sua especificidade. Consequentemente, ficaram à margem" (ARROYO et. al., 2004, p. 10).

No que tange às organizaçóes da sociedade civil, reivindicadoras da garantia dos direitos constitucionais e cobradoras do Estado no cumprimento de seu papel de provedor das necessidades coletivas, não chegarão a produzir os resultados esperados sem a especial atenção a uma questão maior - a promoção da educação libertária, mesmo auxiliando como partícipe na implementação de políticas públicas. Para tanto, em seus projetos de qualificação, precisam compreender que necessitam ultrapassar a si mesmas e lutarem, de maneira organizada e verdadeiramente ética, pela promoção da autonomia dos indivíduos, não nutrindo inconsequentemente o individualismo como o neoliberalismo requer, mas fomentando a autonomia como um processo de ação coletiva em busca de soluções para a melhoria da qualidade de vida de todos.

Nessa perspectiva, Freire (1996, p. 135) reforça que

mesmo quando você se sente, individualmente, mais livre, se esse sentimento não é um sentimento social, se você não é capaz de usar sua liberdade recente para ajudar os outros a se libertarem através da transformação da sociedade, então você só está exercitando uma atitude individualista no sentido do empowerment ou da liberdade.

Reconhecendo a conquista da autonomia como empreitada coletiva, devendo ser utilizada a favor da coletividade, argumenta-se, entáo, que não se acredita em desenvolvimento real sem autonomia, nem ambos sem a conquista do poder; do conhecimento que possibilita a percepção crítica da realidade e a reação frente às injustiças sociais. E nesse movimento de ruptura, de ação, é que a educação se mostrou, ao longo da história, ser uma importante frente de luta, como já dizia Paulo Freire (1986).

\section{Educação do/no campo: construçáo de uma pedagogia do movimento}

Essa história é muito bem contada pelos estudiosos e militantes da área, Miguel Arroyo, Roseli Caldart e Mônica Molina (2004) dentre 
outros, dando voz e repercutindo o desejo de um grupo que brada um pedido de respeito a uma população historicamente marginalizada; um manifesto por uma educação não periférica a das cidades, que considere a singularidade do modo de vida do homem e mulher do campo; que considere sua história, valores, cultura e identidade; e que desmistifique o campo como lugar atrasado, obsoleto e fadado à extinçáo.

Essa retrovisão histórica começa com a luta dos movimentos sociais e dos educadores e educadoras do campo pelo direito à educação, assim como à reforma agrária. Direito esse, vale destacar, que foi negado e usurpado à população brasileira do campo há décadas, com raízes que remontam o processo de colonização da nação brasileira, como salienta Batista (2011, p. 54-55):

As lutas no campo brasileiro têm início com o processo de invasão e colonização portuguesa. Os movimentos se originam dos conflitos em torno da luta por terra, mas também se rebelam contra as relações sociais de produção marcadas pela exploração, pela dominação e degradação da pessoa humana, como a escravidão, contra a negaçấo da cidadania, pelos direitos sociais e trabalhistas, pelo reconhecimento das diferentes culturas. Essas múltiplas demandas envolveram diferentes sujeitos, índios, negros, caboclos, agricultores, escravos, ferreiros, barqueiros. O que denota que a resistência dos povos oprimidos e despossuídos esteve presente ao longo da história brasileira, nos períodos colonial, monárquico e republicano e é um dos elementos da identidade política do povo.

Nos séculos seguintes à colonização portuguesa, até meados do início do século XIX, ainda segundo a autora, é fato que diversas mudanças socioeconômicas e culturais ocorreram - sobretudo por força dos processos de resistências - sem, contudo, provocarem transformaçôes sociais efetivas e duradouras, especialmente no campo da educação, prevalecendo o método pedagógico jesuítico do Período Colonial, que se estendeu de 1549 a 1759, ressoando nas décadas seguintes até a Independência. Com essa ruptura, daí em diante, algumas iniciativas relativas à educação foram efetivadas, contudo, apesar dos avanços na área, ainda não se tinha um sistema educacional de âmbito nacional, o que só se concretizou no século XX.

Em relaçáo à educação do campo, os militantes e profissionais por uma educação diferenciada do campo declaram que apesar dos movimentos docente 
e pedagógico progressista do Brasil buscarem o reconhecimento da educação como um direito humano desde a década de 1980, as conquistas alcançadas pelo movimento não geraram os frutos esperados no campo. Argumentam que o direito à educação, então, conquistado pelo movimento progressista "ficou vinculado a uma concepção abstrata de cidadania, não traduzindo a concretude humana e social em que os direitos se tornam realidade" (ARROYO et. al., 2004, p. 10). Tal concepção reafirmava o discurso elitista da época, ao considerar cidadáos somente os habitantes da cidade.

Diante desse contexto, fica clara, então, na percepção aguçada dos autores citados, em especial, na releitura do assunto por Roseli Caldart (2009), que a Educação do campo nasceu, essencialmente, como crítica à realidade do sistema educacional no Brasil, particularmente à situação educacional da populaçáo brasileira que trabalha e vive no/do campo. Uma crítica não apenas à educação, mas ao modelo de sistema econômico capitalista e sua injusta distribuição de renda; ao incentivo ao agronegócio e a expropriaçáo de terras tradicionais; à elitizaçáo do acesso à ciência, à tecnologia, à cultura e às suas produçôes; enfim, críticas à não universalização de direitos que garantem a plena cidadania.

Dessa forma, a crítica, ainda na visão da autora, não foi voltada exclusivamente à educação escolar em si, mas como essa educação estava desalinhada à realidade educacional do país, que náo considerava a especificidade dos processos sociais, políticos e culturais pujantes do campo, processos estes que extrapolavam sobremaneira as discussóes para além de uma educação linear, cartesiana e formadora de indivíduos na ótica do capitalismo; e ainda, como essa educação desconsiderava a totalidade do sujeito, sua natureza e condição de agente sócio-histórico-cultural, ou seja, "precisamos considerar na análise que há uma perspectiva de totalidade na constituição originária da Educação do campo" (CALDART, 2009, p. 38). Vale destacar que a crítica náo se deu no campo da epistemologia da educação (ainda que isso ocorresse naturalmente por consequência do processo), pelo contrário, foi fundamentada numa "crítica prática", forjada no calor das reivindicaçóes dos movimentos sociais, que lutavam pelo direito à educação a partir da "realidade da luta pela terra, pelo trabalho, pela igualdade social, por condiçóes de uma vida digna de seres humanos no lugar em que ela aconteça” (Ibid. p. 39). Tratou-se então, de

[...] uma crítica prática que se fez teórica ou se constituiu também como confronto de ideias, de concepçóes, quando 
pelo 'batismo' (nome) assumiu o contraponto: Educação do campo não é Educação rural, com todas as implicaçōes e desdobramentos disso em relação a paradigmas que não dizem respeito e nem se definem somente no âmbito da educaçáo (CALDART, 2009, p. 40).

Retornando à sua origem, sabida e reconhecidamente, os grandes protagonistas do processo de criação da Educação do campo e seu aperfeiçoamento foram os "movimentos sociais camponeses em estado de luta", com destaque aos movimentos sociais de luta pela reforma agrária, particularmente ao Movimento dos Trabalhadores Rurais Sem Terra (MST).

No decorrer da luta, outros movimentos sociais em defesa do povo campesino foram surgindo e aderindo à causa por uma educação do campo, consolidando-a como hoje a conhecemos: o Movimento dos Atingidos por Barragens (MAB), o Movimento das Mulheres Camponesas (MMC), o Movimento dos Pequenos Agricultores (MPA), a Pastoral da Juventude Rural (PJR), a Comissão Pastoral da Terra (CPT) e a Federaçáo dos Estudantes de Agronomia (FEAB). Somaram-se às iniciativas o movimento sindical do campo, especialmente àqueles vinculados à Confederação $\mathrm{Na}$ cional dos Trabalhadores da Agricultura (CONTAG) e à Federação dos Trabalhadores da Agricultura Familiar (FETRAF). Assim,

o vínculo de origem da Educação do campo é com os trabalhadores 'pobres do campo', trabalhadores sem-terra, sem trabalho, mas primeiro com aqueles já dispostos a reagir, a lutar, a se organizar contra 'o estado da coisa', para aos poucos buscar ampliar o olhar para o conjunto dos trabalhadores do campo (CALDART, 2009, p. 41).

Para a autora, talvez seja essa a marca histórica mais incômoda e fascinante da Educação do campo no contexto sócio-histórico-político-econômico e cultural do país: o protagonismo e a autonomia dos sujeitos que vivem do/no campo. Hoje, por todo país, podemos afirmar que

[...] milhares de educadoras e educadoras se mobilizam, se reúnem, debatem, estudam e refazem concepçóes e práticas educativas em escolas de comunidade camponesas, em escolas-família agrícola, em escolas dos reassentamentos do Movimento dos Atingidos pelas Barragens, em escolas de 
assentamentos e de acampamentos do Movimento dos Sem Terra, ou em escolas de comunidades indígenas e quilombolas (ARROYO; CALDART; MOLINA, 2004, p. 9).

Assim, diante o exposto, fica evidente que a Educação do campo surgiu em um determinado momento e contexto histórico brasileiro que não pode ser compreendida e analisada em si mesma, segundo afirma Caldart (2009), tomando unicamente por base os "parâmetros teóricos da pedagogia”. Ela extrapola o campo da ciência da educaçáo e provoca reflexóes em várias outras áreas, como a política, a sociologia e a economia; gerando discussóes no intuito de romper velhos paradigmas e propor novos caminhos para um desenvolvimento mais ético, justo e igualitário.

\section{Educaçáo como prática da liberdade: contributos da Educação do Campo para construçáo da autonomia de homens e mulheres do campo}

Exposto em que contexto a Educação do Campo surgiu e se desenvolveu (a educação do campo como crítica ao sistema e como resultado da luta de classes, protagonizado pelos atores sociais que reivindicavam a educação como um direito), partamos agora para outra frente de compreensão do fenômeno, a educação do campo como práxis pedagógica, como princípio e fundamento da luta e das conquistas dos trabalhadores e trabalhadoras.

Preliminarmente à apresentaçáo dessa outra frente de entendimento da Educação do Campo enquanto fenômeno não apenas educativo, mas social, cabe aqui destacar a realização e os resultados das discussóes e consensos da I Conferência Nacional Por uma Educação Básica do Campo, realizada em Luziânia, Goiás, entre 27 a 31 de julho de 1998, evento que segundo seus participantes e idealizadores é considerado o "batismo coletivo" de toda uma luta pelo direito à educação, na qual, foram discutidas e analisadas várias demandas, dentre elas: a) o tipo de educação que estava sendo ofertada no campo era contrária à proposta de educação proposta pelo movimento, uma educação mais ampla, voltada à formaçáo humana do sujeito; b) revisão do que se entende por educação básica e escolarização, resultando na formulação de uma proposta de escola do campo, que considere experiências exitosas e significativas de educação não formal e de caráter popular; c) a substituição do termo "meio rural" por "campo", a fim de trazer ao termo a essência do conceito de camponês, que representa 
a diversidade de sujeitos que vivem do/no campo; d) a construção de pilares metodológicos para uma educação básica do campo, que representasse seu caráter diferenciado, assumindo a identidade do meio rural e voltado a um projeto nacional de desenvolvimento do campo brasileiro.

Não podemos perder de vista, a riqueza das experiências e aprendizagens adquiridas por Miguel Arroyo, quando da sua participação no $1^{\circ}$ Encontro de Educadores dos Assentamentos de Belo Horizonte, em 1994, e na $1^{\text {a }}$ Conferência Nacional Por uma Educaçáo Básica do Campo, em 1998, o que ele chama de pedagogia dos gestos, pedagogia do fazer, expressando as muitas formas de expressão e linguagens utilizadas pelos educadores e membros dos movimentos sociais do campo, que a todo o momento, formam e educam para a cidadania, uma nova concepção de escola. A grande reflexão e contribuição trazida pelos documentos resultantes desses encontros é o 'movimento social como princípio educativo' e como ferramenta de luta por direitos. Para Arroyo, Caldart e Molina (2004), "[...] o movimento social no campo representa uma nova consciência do direito a terra, ao trabalho, à justiça, à igualdade, ao conhecimento, à cultura, à saúde e à educação" (p. 73).

No início dos anos 2000, Roseli Caldart escreveu o documento intitulado A Escola do Campo em Movimento, o qual retrata a experiência particular das escolas do Movimento Sem Terra (MST) e sua proposta pedagógica de formação para a autonomia, a partir da dinâmica das lutas pela implementação de um projeto de desenvolvimento do campo. $\mathrm{O}$ texto carrega em si três importantes argumentos e pontos de reflexão: o primeiro, de que o campo no Brasil encontra-se em constante movimento e processo de mudança social; o segundo, de que a Educação do Campo está sendo construída na dinâmica social desse processo desenvolvimentista, sendo retroalimentada a todo instante pelos atores sociais que dela participam; terceiro, de que é dinâmico o processo de humanização no campo a partir da educação e da assunção dos sujeitos enquanto sujeitos sócio-histórico-culturais, agentes de transformação, protagonistas de suas próprias histórias de desenvolvimento, pessoal e social.

Em seguida, Bernardo Fernandes redige as Diretrizes de uma Caminhada, documento que se configura como uma grande conquista do Movimento "Por uma Educação do Campo" iniciado em 1998, trazendo uma análise dos significados da aprovação, pelo Conselho Nacional de Educação, das Diretrizes Operacionais para a Educaçáo Básica nas Escolas do Campo. O texto faz menção a uma caminhada que se iniciou em 
1997, quando teve a realização do Encontro Nacional de Educadores e Educadoras da Reforma Agrária (ENERA) - evento em que se começava a materializar as ideias progressistas que mais adiante resultou na criação do Setor de Educaçáo na estrutura organizacional do MST, que, mesmo tendo todo o sistema educacional contra, alimentava o desiderato de uma "nova escola". Em síntese, a aprovação das referidas diretrizes representa a conquista da cidadania no meio rural por meio da luta e a luta traduzida em lei, resgatando o campo como lugar de desenvolvimento humano, como "[...] lugar de vida, onde as pessoas podem morar, trabalhar, estudar com dignidade de quem tem o seu lugar, a sua identidade cultural" (ARROYO; CALDART; MOLINA, 2004, p. 137).

E, por último, o texto que finaliza a retrospectiva histórica do Movimento "Por uma Educação do Campo" é chamado de Por Uma Educação do Campo: traços de uma identidade em construção, escrito por Roseli Caldart a partir de sua exposição no Seminário Nacional Por uma Educação do Campo, realizado em Brasília, no período de 26 a 29 de novembro de 2002. E como o próprio título sugere, propóe reflexóes sobre a identidade dos protagonistas do movimento e daqueles que pretendem disseminar seu ideário. Em resumo, o texto destaca que

na sua origem, o 'do' da Educação do campo tem a ver com esse protagonismo: não é 'para' e nem mesmo 'com': é dos trabalhadores, educação do campo, dos camponeses, pedagogia do oprimido... Um 'do' que não é dado, mas que precisa ser construído pelo processo de formação dos sujeitos coletivos, sujeitos que lutam para tomar parte da dinâmica social, para se constituir como sujeitos políticos, capazes de influir na agenda política da sociedade (CALDART, 2009, p. 41).

Partindo do pressuposto, foi justamente por melhores condiçóes e qualidade de vida nos acampamentos e assentamentos do MST que a luta pelo direito à educaçáo se juntou à luta pela terra, no começo sem muita relaçáo. Todavia, desde o princípio da luta social, os trabalhadores e trabalhadoras do campo já carregavam em si a certeza de que uma transformação mais profunda se daria por meio da educação, conforme sublinha Caldart (2000), mas a instauração e consolidação de um modelo educativo dinâmico, que esteja voltado à formaçáo para a autonomia, para a plenitude, para a formação de sujeitos qualificados à construção de novos paradigmas de educação e desenvolvimento, com mudanças educativas e 
sociais efetivas e duradouras, que inclua e considere o homem e a mulher do campo e suas utopias.

Passados dez anos da inauguração do Assentamento Luís Inácio Lula da Silva, localizado no Sul da Bahia, procuramos desenvolver uma pesquisa no intuito de investigar e compreender de que modo os indicadores de desenvolvimento refletem o grau de autonomia de seus moradores, e qual o papel da educação no processo de formação de sujeitos autônomos.

A pesquisa revela que, em relação ao acesso à educação formal no assentamento, majoritariamente, mulheres (100\%) e homens (93,33\%) pesquisados/as afirmam terem este direito garantido, com igualdade de oportunidade a todos que desejam estudar, bem como respeitando as especificidades dos homens e mulheres do campo.

Já em questôes relacionadas com os processos de luta social como estratégias de formação do sujeito, $100 \%$ das mulheres e $80 \%$ dos homens pesquisados atestam que a luta pela terra, pelo trabalho e por condiçóes de uma vida digna tem relação com a sua educação e a dos seus filhos. Também, 93,33\% das mulheres e $80 \%$ dos sujeitos pesquisados reconhecem que a participação do movimento tem influência positiva no modo como eles e seus filhos aprendem e vivem dentro e fora do Assentamento, comprovando que há uma pedagogia dentro e fora da escola, circunscrita na luta, no movimento.

Tanto nos dados quantitativos trazidos na pesquisa, quanto nos qualitativos representados nas falas dos sujeitos, evidencia-se a importância atribuída à educação para o desenvolvimento sócio-econômico-cultural e ambiental do assentamento, dando grande destaque ao MST como promotor da expansão das liberdades e capacidades do indivíduo, formando-o para o exercício da cidadania. Os resultados reforçam as palavras de Cury (2002, p. 260), quando declara que

o acesso à educação é também um meio de abertura que dá ao indivíduo uma chave de autoconstrução e de se reconhecer como capaz de opçóes. O direito à educação, nesta medida, é uma oportunidade de crescimento cidadão, um caminho de opçóes diferenciadas e uma chave de crescente estima de si.

Nesta percepção de formação para autonomia, Caldart (2009, p. 5) também destaca que "Os Sem Terra se educam, quer dizer, se humanizam e se formam como sujeitos sociais no próprio movimento da luta que 
diretamente desencadeiam". A afirmação da autora corrobora a narrativa de Areca, quando define a educação como instrumento que potencializa a luta, e o conhecimento como um bem inviolável de homens e mulheres.

A educação é a base de tudo né, entáo assim se você não tem educaçáo [...] náo consegue até mesmo lutar né, porque se você não tiver educação, você não tem a capacidade de ir pra luta né, então, o conhecimento né, esse conhecimento vem através da educação [...] não ter dinheiro é uma coisa, agora você enquanto pessoa, você tem os seus direitos né, você tem o direito a estudar, é através do estudo que você vai ter uma vida mais digna né, porque o conhecimento é algo que ninguém tira de você, não é? Entáo é isso que você leva pra sua vida, e o Movimento Sem Terra esclarece muito bem isso, é dizer: oh, você tem direitos né, você é dono do seu próprio destino, não é os outros que vai fazer o seu destino, e sim você mesmo (ARECA, excerto extraído do Grupo Focal no 1 , realizado em maio de 2016).

Areca (2016) também nos chama atenção ao papel do MST frente à construçáo da autonomia dos sujeitos, especialmente ao declarar que cada um é dono do seu próprio destino, contudo, apreendendo o que tem de direito e lutando por ele. Desse modo, como destaca Freire (1983, p. 32), a autonomia é uma conquista e implica libertação das estruturas opressoras. "A libertação a que não chegarão pelo acaso, mas pela práxis de sua busca; pelo conhecimento e reconhecimento da necessidade de lutar por ela".

Outro relato que merece destaque, dentre outros, é o de Aricuri, relembrando umas das místicas do movimento, "o assentamento é a nossa escola e o MST é o nosso principal educador”, vê-se nessa frase que educar não é somente o papel da instituição escolar, mas o território, o movimento, a casa, a terra, que vão se configurando numa grande escola, e vão tecendo currículos que náo estáo preocupados apenas com o seguimento escolar, mas com a vida, o trabalho e a luta, dentre outros elementos. Ainda em relação à frase supracitada, Aricuri (2015) diz que

ela acaba ajudando a todos nessa parte da educação, porque em primeiro lugar, primeiramente em tudo, pra gente buscar tudo, a gente precisa ter a educação, não é a educação que ocorre em quatro paredes, que é uma escola ali que vai formar, 
e sim aquela educação que está presente no buscar, no agir, é aquela educação diferenciada que você precisa compreender que náo é só em quatro paredes que você vai obter essa educaçáo, é nessa conversa que a gente ta tendo aqui, que a gente vai direcionar, que a gente vai buscar esse passo a passo, não precisa a gente está nessa visão da escola de quatro paredes, mas debaixo de um pé de árvore, em uma palestra que a gente tem ali... na busca pela educação, o movimento ele se preocupa muito, em primeira instância ele se preocupa em montar num acampamento, o segundo objetivo dele é a escola, ali junto com a saúde [...] ele procura buscar cada dia mais cursos: às vezes, a gente vai está em uma reunião, em uma assembleia, por exemplo, ali nós achamos que só é uma discussão que está no assentamento, muitos náo conseguem compreender que aquela assembleia tá sendo uma escola, porque aquela assembleia ali, ela tá direcionando, entáo isso que é interessante, que a cada dia me passa a cativar mais pelo movimento, porque você sem perceber acaba, a cada instante, aprendendo, como diz, somos eternos aprendizes né, a cada momento a gente tá ali buscando [...] (Excerto extraído do Grupo Focal no 4, realizado em maio de 2015 - grifos nossos)

Evidencia-se neste discurso a relevância da educação não formal dentro do MST, uma educação para além dos muros da escola; uma educação que se dá na práxis da vida cotidiana, no exercício da cidadania e na participação social; uma educação que se oportuniza na luta por direitos, no enfrentamento às estruturas de poder e opressão; o que Kant (1996, p. 30) bem defende quando diz que "a educação não deve ser puramente mecânica nem se fundar no raciocínio puro, mas deve apoiar-se em princípios e guiar-se pela experiência", por aquilo que nos toca, como bem traduz Aricuri: "uma aprendizagem infinita com os pares, nas reuniôes, nas assembleias, nas conversas, nas ocupações, nos conflitos, na luta".

Formar para a autonomia, tornar consciente e reflexivo este processo de aprendizagem que se dá na trajetória de luta é, para Caldart (2009), um dos grandes desafios pedagógicos do MST na atualidade e uma das principais razões de se valorizar cada vez as estratégias e práticas pedagógicas próprias desencadeadas no interior dos assentamentos e acampamentos do movimento.

Neste sentido, somente nos assumindo como seres sócio-histórico-culturais, como recomenda Freire (2007), nos reconhecendo como sujeitos de ação e ressignificação na/da história, poderemos avançar nesta 
expansão de capacidades e liberdades fundamentais, neste estado de consciência crítica e reflexão a que chamamos de autonomia. Sem isto, conforme Caldart (2009, p. 6), "os novos sujeitos sociais não conseguirão se tornar sujeitos políticos, capazes de efetivamente fazer diferença no desenrolar da luta de classes, e na reconstruçáo de nosso projeto de humanidade".

$\mathrm{Na}$ visão da autora, os sem-terra se educam, se formam, se libertam e, enfim, se humanizam como sujeitos sociais na medida em que participam do próprio movimento da luta pela terra e por direitos, ou seja, como já dizia Freire: "a libertação a que não chegarão pelo acaso, mas pela práxis de sua busca; pelo conhecimento e reconhecimento da necessidade de lutar por ela" (FREIRE, 1983, p. 32).

Os relatos dos sujeitos dessa pesquisa evidenciam, a todo o momento, o quáo educativo é a vivência dos processos de luta pela terra e manutenção e desenvolvimento das áreas de assentamento. A escola se configura como mais uma ferramenta de formação para autonomia dos sujeitos que ali vivem, dentre tantas outras que se desenvolvem na dinâmica da vida em comunidade. A educação, seja formal ou não, tem especial relevância e influência no desenvolvimento sócio-econômico-cultural e ambiental do Assentamento, destacando-se o princípio educativo do próprio MST, como agente promotor da expansáo das liberdades e capacidades dos sem-terra, formando-os para a autonomia e para o exercício da cidadania.

Diante o exposto, a todo o momento, procurou-se despertar para a necessidade urgente de uma mudança de comportamento social, a partir do entendimento de que não se pode alcançar o desenvolvimento à custa da privação do outro de participar, contribuir e usufruir do mesmo; a partir do reconhecimento de que o desenvolvimento é influenciado, inegável e positivamente, pelo acesso às oportunidades econômicas, liberdades políticas, poderes sociais e por condiçóes habilitadoras, com destaque aqui para a educação.

\section{Referências}

ADORNO, T.W. Negative Dialektik. In: ADORNO, T.W. Gesammelte Schriften. v. 6. Frankfurt am Main: Suhrkamp, 1984.

ARROYO Miguel Gonzalez; CALDART Roseli Salete; MOLINA Mônica Castagna (Orgs.). Por uma educaçáo do campo. Petrópolis, RJ: Vozes, 2004. 
BATISTA, Maria do Socorro Xavier (Org.). Movimentos sociais, estado e políticas públicas de educaçáa do campo: pesquisa e práticas pedagógicas. João Pessoa: UFPB, 2011.

BOBBIO, N. O Futuro da democracia. São Paulo: Brasiliense, 2000.

BRASIL. Constituição (1934). Constituiçáo da República dos Estados Unidos do Brasil. Rio de Janeiro, 1934. . Constituição (1937). Constituiçáo da República dos Estados Unidos do Brasil. Rio de Janeiro, 1937. . Constituição (1946). Constituição dos Estados Unidos do Brasil. Rio de Janeiro, 1946.

. Lei de Reforma Agrária (Lei no 4.504/64). Brasília, 1964.

. Constituição (1967). Constituição da República Federativa do Brasil. Brasília, 1967.

. Constituição (1988). Constituiçáo da República Federativa do Brasil. Brasília-DF: Senado Federal: Centro Gráfico, 1988.

. Ministério da Educação. Conselho Nacional de Educação. Diretrizes operacionais para a Educaçáo Básica nas Escolas do Campo. Brasília-DF, 2001.

. Ministério da Educação. Grupo de Trabalho de Educação do Campo. Referências para uma política nacional de educação do campo. Caderno de Subsídios, Brasília-DF, 2003.

CALDART, Roseli Salete. Educaçáo em Movimento: Formação de educadores e educadoras no MST. Petrópolis, RJ: Vozes, 1997.

. A escola do campo em movimento. Contexto e Educaçáo, Ijuí, v.15, 2000.

. Pedagogia do Movimento Sem-Terra. Petrópolis: Vozes, 2000.

. Educação do Campo: notas para uma análise de percurso. Trab. educ. saúde, Rio de Janeiro, v. 7 n. 1, p. 35-64, mar./jun., 2009. Disponível em: < http://www.scielo.br/pdf/tes/v7n1/03.pdf>. Acesso em: out. 2015.

CASTORIADIS, C. A Instituiçáo imaginária da sociedade. Rio de Janeiro: Paz e Terra, 1991. 
CHAUÍ, Marilena de Souza. Cultura e Democracia: o discurso competente e outras falas. 5. ed. São Paulo: Cortez Editora, 1990.

CURY, Carlos Roberto J. Direito à educação: direito à igualdade, direito à diferença, Cadernos de pesquisa, n. 116, p. 245-262, jul./ 2002.

Disponível em: <http://www.scielo.br/scielo.php?script=sci_arttext\&pid =S0100-15742002000200010>. Acesso em: out. 2015 .

FREIRE, Paulo. Pedagogia do Oprimido. 12. ed. Rio de Janeiro: Paz e Terra, 1983.

Pedagogia da autonomia: saberes necessários à prática educativa. São Paulo: Paz e Terra, 1996. (Coleção Leitura)

. Pedagogia da autonomia: saberes necessários à prática educativa. 36 . ed. Rio de Janeiro: Paz e Terra, 2007.

FREIRE, Paulo. SHOR, Ira. Medo e ousadia: o cotidiano do professor. Rio de Janeiro: Paz e Terra, 1986.

FREY, K. Políticas públicas: um debate conceitual e reflexões referentes à prática da análise de políticas públicas no Brasil. Planejamento e Políticas Públicas, Rio de Janeiro, 2000, n. 21, p. 211-259. Disponível em: http://www.ipea.gov.br/ppp/index. php/PPP/article/viewFile/89/158. Acesso em: 12 jul. 2011.

KANT, Immanuel. Fundamentação da metafísica dos costumes. São Paulo: Abril Cultural, 1974. (Coleção Os pensadores)

. Crítica da Razão Pura. Trad. Valério Rohden e Udo Valdur

Moosburger. São Paulo: Nova Cultural, 1996.

ONU - Organização das Nações Unidas. Declaração Universal dos Direitos Humanos, 1948.

1966.

. Pacto Internacional dos Direitos Econômicos, Sociais e Culturais,

PEREIRA, Miguel Ribeiro. A inclusão da autonomia como indicador de desenvolvimento humano diante da formação da social brasileira. Jornada Internacional de Políticas Públicas (JOINPP). III Jornada Internacional de Políticas Públicas. São Luís - MA, 28 a 30 de agosto 2007.

SEN, Amartya Kumar. Desenvolvimento como liberdade. Tradução de Laura Teixeira Motta; revisão técnica Ricardo Doniselli Mendes, São Paulo: Companhia das Letras, 2008. 


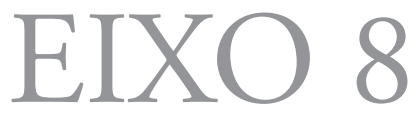

Movimentos sociais, educação e pedagogias alternativas na América Latina - sujeitos e experiências 


\title{
MOVIMENTOS SOCIAIS, EDUCAÇÁO E DIÁLOGO DE SABERES NA AMÉRICA LATINA
}

\author{
Lia Pinheiro Barbosa ${ }^{1}$
}

\section{Introdução}

O presente escrito é uma reflexão apresentada por mim em conferência realizada no I Congresso Internacional e III Nacional Movimentos Sociais e Educação, realizado em 2016, na Universidade Estadual de Santa Cruz (UESC), em Ilhéus-Bahia, e que articula a temática central da Mesa-Redonda sobre Educação na América Latina aos debates realizados no âmbito do Círculo de Diálogo "Movimentos Sociais, Educação e Pedagogias Alternativas na América Latina: sujeitos e experiências", coordenado por minha pessoa, pela Dra. Marcela Sollano, da Universidad Nacional Autónoma de México (UNAM) e pela Dra. Lidia Rodríguez, da Universidad Autónoma de Buenos Aires (UBA). ${ }^{2}$

Para mim, pensar os movimentos sociais e a educação requeria assumir a América Latina como ponto de partida, para evocar a trajetória da Educação Popular no continente e seu papel político em momentos cruciais da história recente de nossa regiáo, marcados por processos de profundo enrijecimento do cenário político, a propósito do que representaram as ditaduras militares para o Cone Sul. Nesse período, a Educação

1 Doutora em Estudos Latino-Americanos pela UNAM. Professora da Faculdade de Educação de Crateús e do Programa de Pós-Graduação em Sociologia da Universidade Estadual do Ceará (UECE). Pesquisadora do Programa Alternativas Pedagógicas y Prospectiva Educativa en América Latina (APPeAL) e líder do Grupo de Pesquisa Pensamento Social e Epistemologias do Conhecimento na América Latina e Caribe. Pesquisadora do Conselho Latino-Americano de Ciências Sociais (CLACSO), no GT Herencias y perspectivas del Marxismo en América Latina e do GT Cuerpos, Territorios y Resistencias. E-mail: <lia.pbarbosa@ gmail.com>.

2 Em ocasião de uma agenda interna da UNAM que requeria a presença imprescindível da Dra. Marcela Sollano, não foi possível sua presença durante o Congresso, a qual foi substituída pela participação da Dra. Lídia Rodríguez, que se vinculou às atividades desenvolvidas durante os dias do evento. 
Popular representou a construção clandestina de uma consciência crítica de base popular, ao mesmo tempo, em que assumia como horizonte utópico ser um projeto educativo-político das organizaçóes populares para a emancipação humana (PUIGGRÓS; SOLLANO, 1986; PUIGGRÓS, 1998; PALUDO, 2001; RIBEIRO, 2008; CABEZAS, 2008; RODRÍGUEZ, 2013).

Nessa direção, a proposição da temática tinha a intencionalidade de recuperar esse caminhar, enlaçando-o com o tempo histórico pós-ditatorial, da democratização política, mas também da instauração da política neoliberal e os novos desafios para a Educaçáo Popular. Mais especificamente, refletir sobre a continuidade desse processo a partir da práxis educativo-política dos movimentos sociais, nas aprendizagens e ensinamentos herdados do acúmulo teórico-político-educativo-pedagógico da Educação Popular, para o nosso momento histórico, isto é, do final do século XX e inícios do século XXI.

Com este recorte temporal, a América Latina apresenta um calendário e uma geografia histórica ${ }^{3}$ que expressa as múltiplas experiências de resistências e rebeldias nascidas da práxis política dos movimentos sociais, especialmente aqueles de caráter indígena, camponês e afrodescendente. $\mathrm{Na}$ dialética da resistência latino-americana, observa-se a emergência de novas semânticas e práticas que destacam um momento histórico particular e peculiar, em que são fortalecidas as lutas históricas para a (re)conformação dos sujeitos histórico-políticos e de novas subjetividades.

A agenda reivindicativa articulada por estes movimentos recupera a memória histórica da resistência latino-americana, ao mesmo tempo em que apresenta novas demandas políticas, a exemplo da construçáo de um projeto autonômico, a defesa do território e dos direitos da natureza, ademais

3 Faço referência à expressão "calendários e geografias" em alusão à análise do Subcomandante Insurgente Marcos, do Exército Zapatista de Libertação Nacional (EZLN), movimento indígena de Chiapas, sul mexicano. A expressáo enfatiza uma crítica à geopolítica do capital, que se demarca em um tempo (calendário) histórico e se legitima geograficamente nos processos históricos de dominação norte-sul. Entretanto, há igualmente uma ênfase nos tempos e calendários das resistências em todo o mundo, os quais dialeticamente interpelam os calendários, a geografia e a teoria hegemônica e demarcam um posicionamento histórico-político dos subalternizados. Nesse sentido, o uso da expressão incorpora este segundo referente, qual seja, aquele relacionado aos calendários e geografias das resistências latino-americanas. A discussão completa encontra-se na publicação resultante do I Colóquio Internacional Andrés Aubry "Planeta Tierra y Movimientos Antisistémicos, realizado em 2007, em São Cristóbal de las Casas, Chiapas - México, referenciada ao final deste escrito. 
de reforçar aquelas demandas de caráter histórico como centro do debate e embate político: a demanda pelos direitos humanos, pelo pleno exercício da cidadania e da democracia, pela realização da reforma agrária, pelo direito à moradia, ao trabalho, à saúde, à educação, entre tantas outras reivindicaçóes que persistiram e seguem em voga desde a voz dos movimentos populares e sociais, seja no contexto rural ou urbano.

Como partícipes de uma complexa trama política, caracterizada por uma difícil disputa social, política e econômica, os movimentos sociais necessitam conformar um sujeito histórico-político que articule um projeto político próprio. No plano educativo-político, tal tarefa pressupóe dois caminhos: primeiramente, um processo contínuo de compreensão e crítica da conformação histórica das relações de dominação e poder em uma sociedade de classe, como a capitalista. Tal empreita é intrínseca à assunção de uma práxis política dialética na disputa de uma nova hegemonia (GRAMSCI, 2011; VÁSQUEZ, 1977). ${ }^{4}$

Em segundo lugar, os movimentos sociais devem ter a capacidade de proposição/criação de outras linguagens políticas que (re)significam os caminhos da resistência e que definem, muito claramente, o anseio em reconstruir, reinventar o político ou, simplesmente, desconstruir os modelos políticos historicamente impostos, por meio de uma outra concepção da política e da educação como práxis política (BARBOSA, 2013).

Inspirados na Educação Popular e em diálogo com o legado teórico-político do pensamento pedagógico latino-americano, da teoria marxista, em especial, os escritos de José Martí, Simón Rodríguez, Makarenko, Pistrak, a Pedagogia do Exemplo (GUEVARA, 2004), a Pedagogia do Oprimido (FREIRE, 1987), ou ainda nutridos de referentes da cosmovisão, cultura e língua materna, os movimentos sociais recuperam o debate político da centralidade da educação para a formação do sujeito revolucionário, e da necessária construção de outra concepção de educação e de pedagogia como projeto político.

4 Recupero a categoria práxis da tradição do pensamento crítico marxista. Adolfo Sánchez Vásquez (1977, p. 185) atenta para o fato de que "toda práxis é atividade, porém nem toda atividade é práxis”. O sentido político que adquire a práxis no marco de um projeto educativo-político se vincula a sua dimensão cognitiva, isto é, de compreensão da práxis como atividade de intervenção no plano da consciência. Por tal razão, a práxis constitui uma ação prefigurativa, ou seja, de pensar a ação humana em virtude de um resultado ideal - produto da consciência - e que se materializa no plano real, concreto da vida. 
Esse processo está atravessado por um giro epistêmico fundamental, sobretudo pela revisão das categorias políticas que se mantiveram por séculos como eixos interpretativos e condutivos dos fenômenos sociais, categorias estas erigidas sob uma lógica teórica e político-ideológica hegemônica, que fincaram profundas raízes a partir dos sistemas educativos modernos. ${ }^{5}$

Com base no exposto, vemos erigirem-se diferentes projetos educativo-políticos articulados pelos movimentos sociais da América Latina, que demarcam uma apropriação política da educação e de Pedagogias Críticas. No cerne dos múltiplos projetos educativo-políticos emergentes no continente se propõe a construção conjunta de saberes que é parte constitutiva das vivências socioculturais destes movimentos e que, portanto, estabelece uma resistência às "verdades" impostas por referentes próprios de uma racionalidade ocidental moderna, comumente presentes nos processos educativos da escola formal. Importante destacar que tais vivências possuem uma dimensão política, uma vez que muitos movimentos sociais (especialmente indígenas, camponeses e afrodescendentes) não dissociam a ação política própria de sua agenda reivindicativa da cotidianidade da vida, seja no âmbito comunitário, comunal, orgânico, ou mesmo, como indivíduos.

5 Vale destacar as análises de Puiggrós (1996), cujo título Presencias y ausências de la historiografia pedagógica latinoamericana se apresenta ilustrativo à temática tratada. Puiggrós afirma que o transcurso de implantaçâo dos sistemas educativos modernos latino-americanos subsidiou uma forma particular de dominaçáo desde um modelo educativo dominante e um processo de consolidação de uma hegemonia baseada na demarcação de um campo simbólico e ideológico que se impóe com vistas a homogeneizar o pensamento social e, assim, manter a supremacia de determinados grupos estabelecidos no poder. Um ponto central nas análises de Puiggrós está relacionado às formas de nomear ao "outro" no campo do discurso historiográfico. A historiografia tradicional estabelece um parâmetro dicotômico para representar o conjunto das relaçóes construídas historicamente na América Latina. Tal abordagem produziu uma perda da especificidade dos vínculos históricos, políticos e, fundamentalmente, socioculturais, servindo à elaboração de uma história latino-americana cujos referentes se reduzem a duas representaçóes aceitáveis: os conquistadores/dominadores e os conquistados/dominados. O resultado imediato desta interpretaçâo dicotômica do nosso continente é a profunda negação da "outredade" e seus referentes diretos, a saber, a multiplicidade, a pluralidade, a multiculturalidade, o heterogêneo, como parte constitutiva da sociedade latino-americana. Esta negação conduziu a diluiçóes das possibilidades de conformação de uma historiografia social que fosse capaz de visibilizar múltiplos sujeitos, dotados de um caráter pluricultural, responsável pela diversidade de experiências e práticas que se mantiveram vivas (apesar da colonização) e que ainda se expressam no âmbito das relações socioculturais, políticas e, especialmente, educativas. 
Exemplares desse processo de construção de projetos educativo-políticos são as experiências educativas do Movimento Sem Terra, no Brasil; o Sistema Educativo Rebelde Autônomo Zapatista de Libertaçáo Nacional (SERAZ-LN), no México; os Bachilleratos Populares, na Argentina; a Universidad Intercultural de los Pueblos y Nacionalidades Indígenas de Ecuador - Amawtay Wasi, no Equador; os Institutos Agroecológicos Latinoamericanos - IALA's: IALA Guarani (Paraguai); IALA Amazônico e Escola Latino-Americana de Agroecologia - ELAA (Brasil); IALA Paulo Freire (Venezuela); IALA María Cano (Colômbia); IALA Mesoamérica (Nicarágua); IALA Mujeres (Chile); além da Universidad Campesina "SURI" (UNICAM SURI), na Argentina; e a Escuela Nacional de Agroecología del Ecuador-ENA, entre outras.

Para o propósito de nossa reflexão no marco do referido evento, não adentrarei em apresentar experiências concretas em curso na América Latina, até porque algumas delas foram apresentadas em outras Mesas-Redondas e nos Círculos de Diálogo. Meu intuito é refletir acerca da relação estabelecida entre a Educação, as Pedagogias Críticas e o Diálogo de Saberes no âmbito de ditas experiências na conformação de sujeitos histórico-políticos e na construçáo de uma teoria política que emana dos movimentos sociais.

Para adentrar nessa reflexão, darei ênfase às experiências educativas do Movimento Zapatista e do MST, sobretudo pelas suas trajetórias políticas de três décadas e o debate hodierno que articulam ante os desafios de inícios de século, a saber, o enfrentamento do capital transnacional e o acirramento dos antagonismos de classe na América Latina.

\section{A Educaçáo e o encontro de pensamentos no enfrentamento da Hidra Capitalista}

Vale recordar que tanto el despojo como la enajenación de nuestro saber, inició una resistencia y una lucha por el reconocimiento, es decir del ich'el ta muk. Xuno López

6 Yo'taninel bajtik, re-ch'ulel-izarnos y revivir lo sagrado desde nuestra propia humanidad como matriz del del fin de la Jow-hidra capitalista, participación de Xuno López el día 8 de mayo del 2015, en el Seminario El Pensamiento Crítico Frente a la Hidra Capitalista. 
O ano do calendário é 2015, a geografia é a Universidad de la Tierra - CIDECI, em San Cristóbal de las Casas, Chiapas, sul mexicano. As palavras de Xuno López ${ }^{7}$ são recuperadas por duas razóes: a primeira, para enfatizar a importância histórica do Seminario El Pensamiento Crítico Frente a la Hidra Capitalista ${ }^{8}$, na perspectiva da confluência de um legítimo diálogo de saberes para pensar chaves interpretativas do capitalismo no nosso tempo histórico e as alternativas para seu enfrentamento desde abaixo e à esquerda, o lugar onde bate o coraçāo ${ }^{9}$. Em segundo lugar, por demarcar uma das marcas mais profundas da colonizaçáo até os nossos dias - a alienação do nosso saber - e por nos lançar uma semente-palavra ${ }^{10}$ fundamental, o ich'el ta muk' que, nas palavras de Xuno López, pode significar em maya-tseltal, justiça, democracia, liberdade, condição imprescindível para a dignidade humana.

O reconhecimento do ich'el ta muk recorre o tempo histórico do que foi a longa noite dos 500 anos $^{11}$, na resistência histórica indígena, negra e camponesa da América Latina, a qual é possuidora de outras sementes- palavras para reivindicar sua dignidade e lançar-se no enfrentamento do Estado e de um modelo de desenvolvimento que prima por despojar seus

7 Maya-tseltal, antropólogo, cofundador do Colectivo Yip Sch'ulel Ko'tantik e da Red de Comunicadores Comunitarios, Artistas y Antropólogos de Chiapas (RACCACH).

8 O Seminário foi convocado pelo Exército Zapatista de Libertação Nacional (EZLN) e realizado em maio de 2015. Constituiu um "encontro de pensamentos", em palavras do próprio EZLN entre diferentes organizaçóes, movimentos sociais e pesquisadores dos cinco continentes.

9 Esta expressão é muito utilizada pelos Zapatistas para reafirmar que seu posicionamento político não é partidário, ou seja, em apoio a algum partido de esquerda. Por outro lado, a referência direta ao coração tem seu sentido na cosmovisão maya, que atribui uma dimensão epistêmica e filosófica a ele, conforme apresentarei ao longo do escrito.

10 Escutei pela primeira vez a expressão semente-palavra (semilla-palabra em espanhol) em 2010, em um diálogo coletivo com os Promotores de Agroecologia do Caracol Oventik, em território Zapatista. Igualmente, é uma expressão usada por Xuno López, na sua exposição no Seminario El Pensamiento Crítico Frente a la Hidra Capitalista. Nesse período (2009-2013), realizava meus estudos de doutorado no México, na UNAM, e tratava de compreender a concepção de educação como projeto educativo-político para os movimentos sociais da América Latina, em particular o MST e o Movimento Zapatista. Claramente, as sementes-palavras representam os conceitos e categorias de análise que emergem a partir do pensamento e a práxis dos movimentos sociais e organizaçóes em resistência.

${ }^{11}$ Metáfora utilizada pelos Zapatistas em alusão aos processos de colonização. 
territórios (HARVEY, 2004), sua língua, sua cultura e, por fim, extirpar suas identidades como povos originários e povos do campo (CUSICANQUI, 2010). Entretanto, conforme enfatiza a palavra zapatista, a rebeldia es parte de una memoria histórica y se hace historia. Mais precisamente (EZLN, 1996, p. 128):

[...] la rebeldía que hoy tiene rostro moreno y lengua verdadera, no se nació ahora. Antes habló con otras lenguas y en otras tierras, muchas montañas y muchas historias, ha caminado la rebeldia contra la injusticia. [...] La rebeldía no es cosa de lengua, es cosa de dignidad y de ser humanos.

Portanto, a insurgência dos povos originários, afrodescendentes e camponesas expressa a busca incessante pela dignidade, justiça e paz... o ich'el ta muk, que seguramente encontrará seu correlato em outras sementes-palavras. Nesse contexto, emerge a denúncia histórica do caráter desumanizador da educação (FREIRE, 1987), pilar do antagonismo de classe (PONCE, 1920), como também dos processos de colonialidade do poder e do saber (QUIJANO, 1999; LANDER, 2005). Daí a necessidade histórica de conceber outra educação, outra(s) pedagogia(s), outra(s) escola(s), caminho fundamental para a conformação do sujeito histórico-politico e na consolidação da emancipação humana como princípio e projeto político.

$\mathrm{Na}$ nossa história recente, observamos como os movimentos sociais têm avançado nesse debate e na elaboração de outra concepçáo de educação e de pedagogias alternativas genuínas, que demarcam a centralidade de um projeto educativo-politico e histórico de conhecimento. Para fins da presente reflexão, gostaria de destacar duas experiências que considero emblemáticas na história recente da nossa região e que muito tem aportado na tessitura de um projeto educativo político: o Sistema Educativo Rebelde Zapatista de Libertaçáo Nacional (SERAZ-LN) e a Educação do Campo, ambas as sínteses do projeto educativo político do Movimento Zapatista e do Movimento Sem Terra (MST), respectivamente. ${ }^{12}$

Dessa maneira, recuperarei alguns eixos que articulam o projeto histórico de conhecimento conduzido por eles, o que implica uma concepção

${ }^{12}$ Em Barbosa (2015), desenvolvo uma análise mais aprofundada do projeto educativo político do MST e do Zapatismo. 
de educação, de pedagogia e de elaboração de conhecimento próprio (BARBOSA, 2016), coração do processo educativo-formativo de ambos os movimentos. A intenção é a de demarcar a centralidade do Diálogo de Saberes na perspectiva da conformação do sujeito histórico-político Zapatista e Sem Terra e de uma teoria coraçonada, teoria revolucionária que nasce desde/ com/para a práxis política dos movimentos.

\section{Da educaçáo como projeto político}

Herdeiros da resistência histórica de seus respectivos países e na perspectiva latino-americana, as e os Zapatistas e os Sem Terra têm compreendido o papel histórico da educaçáo, da pedagogia e da escola na introjeçáo dos signos no campo simbólico-ideológico de uma subordinação cultural e dominação política. Conforme o Ezln (1996, p. 123):

Uno de los pilares fundamentales de la reproducción del sistema politico es la educación, la cual se ha utilizado como instrumento para legitimar la gobernabilidad a través de una dinámica que busca formar una masa de población productiva, pero no reflexiva o critica; que impulsa la homogeneización y anula las diferencias culturales y de género, ignorando absolutamente la idiosincrasia de los medios rurales y las lenguas autóctonas; que fomenta el individualismo y la competencia reforzando el sistema de mercado, la desigualdad y la discriminación; que no respeta, ni considera las necesidades vitales ni el derecho de elección del tipo de vida.

Enfrentar o papel histórico da educação significa elaborar outra concepção de educação e de pedagogia, primeiro passo para conformar o sujeito politico revolucionário responsável pelo seu processo de libertação e emancipação humana. Nessa perspectiva, os dois movimentos sociais mencionados me parecem exemplares, sobretudo porque ao longo de três décadas de maturação do projeto histórico-político da educação, da necessária apropriação de sua concepção, de sua práxis e de sua intencionalidade na trajetória política de ambos os movimentos. No debate educativo representa, para o MST (2005, p. 5-6)

uma relação de origem: a história do MST é a história de uma grande obra educativa. E, de fato, frente a uma ocupaçáo 
de terra, de um acampamento, de um assentamento, de uma Marcha, de uma escola conquistada pelo Movimento, é cada vez mais pertinente perguntar: como cada uma dessas açóes educa as pessoas? Como se forma uma determinada forma de ser humano? Que aprendizagens pessoais e coletivas estáo presentes em cada uma delas?

Dessa maneira, estes dois movimentos sociais têm conseguido consolidar um projeto educativo-político, responsável por inserir-se no campo de disputa de projetos educativos nos seus respectivos países e demonstrado ao mundo que não só é possível conceber outra educação, outra pedagogia e outra escola, mas também construir um conhecimento que demarca/recupera outro paradigma para pensar-se a si mesmos, nos seus calendários e geografias.

Nesse labor, cobra particular importância a dimensão epistêmica da educação, isto é, o saber ou conhecimento da realidade das coisas, que deriva das experiências construídas e vivenciadas no plano individual e coletivo, em um determinado tempo e espaço. A dimensão epistêmica pressupóe um posicionamento pré-teórico ante a realidade, que permita estabelecer uma relaçáo dialética e dialógica entre realidade e conhecimento, proporcionando ao sujeito histórico-político não só interpretá-lo, como também, teorizar sobre o mesmo (BARBOSA; GÓMEZ-SOLLANO, 2014). Esta dimensão pode ser considerada o coração do projeto educativo político do Zapatismo e do MST, na consolidação do SERAZ-LN (EZLN, 1996) ${ }^{13}$ e na concepção da Educação do Campo (ARROYO et. al., 2004).

É fundamental destacar que nos contextos histórico-políticos do Brasil e do México, os processos de colonização e, ulteriormente, de legitimaçáo de um projeto de modernidade se deram sob a destruição de uma

${ }^{13}$ O SERAZ-LN compreende a Educação Primária Rebelde Autônoma Zapatista e a Educação Rebelde Autônoma Zapatista. Como parte do projeto autonômico Zapatista, as escolas autônomas não recebem nenhum financiamento público por parte da Secretaria de Educação Pública de Educação, no México, muito menos são reconhecidas por ela. As Promotoras e Promotores de Educação não recebem um salário pelo seu labor educativo e a mediação pedagógica é de caráter comunal, ou seja, toda a comunidade se faz responsável pelo processo educativo-formativo, da infância e da juventude Zapatista. Nesse sentido, a comunidade, em assembleia, decide o conteúdo abordado nas escolas autônomas e garante a alimentação dos jovens e das/dos Promotores de Educação, durante o período escolar. 
matriz multilíngue e instauração de uma matriz monolíngue, com a substituição forçada das línguas originárias pelas línguas do colonizador, com a incorporação do conjunto dos signos linguísticos e seus referentes de ordem epistêmica. No âmbito educativo, a mediação pedagógica existente no espaço escolar viabilizou a constituição de uma linguagem que legitima a racionalidade dominante, cristalizadora das relaçóes de poder e dominação. Uma linguagem que regula e legitima um discurso histórico de negaçâo do "outro" (CARBONI; MAESTRI, 2012) representado pelos povos originários e camponeses, que culminou no esquecimento, exploração e expropriação históricos, amplamente denunciados pelo EZLN e o MST, no conjunto de documentos e comunicados produzidos por ambos. ${ }^{14}$

Outro elemento a considerar é aquele, predominante no Brasil, da contradição inventada entre "campo-cidade", igualmente debatida e combatida pelo MST. Uma racionalidade que acentua o menosprezo pelo campo, considerado o espaço do atraso político-econômico e cultural; também da mulher e do homem do campo como indivíduos culturalmente inferiores. Uma racionalidade que reforçou, cabalmente, o êxodo rural no Brasil e que encontra seu correlato no México (CALDART, 2004; BARBOSA, 2014; 2015a). ${ }^{15}$

No projeto educativo-político dos Sem Terra e dos Zapatistas, o Diálogo de Saberes expressa a apropriação dos referentes epistêmicos oriundos da matriz cultural, identitária, dos saberes e experiências, como também daqueles provenientes do legado teórico-político que embasa o conjunto de demandas políticas. Portanto, representa um verdadeiro telar em que são tecidos os fios que comporão as matrizes constitutivas do sentir- pensar-saber-ser que dão conta do pensamento e da práxis educativo-pedagógica-política do sujeito coletivo Sem Terra e Zapatista.

${ }^{14}$ Gramsci desenvolveu uma valiosa análise acerca do papel das instituiçôes sociais, a exemplo da Igreja, da Universidade, na legitimação do que ele denominava "gramática normativa”, aquela que consolida, no plano ideológico, uma linguagem que legitima as relaçóes de dominação e poder do Estado (GRAMSCI, 1987).

15 O menosprezo pelos indígenas também é um fato histórico no México. Inclusive, é analisado náo apenas do ponto de vista da historiografia e antropologia mexicana, mas também no âmbito da Literatura, a exemplo da obra literária de Rosario Castellanos (1962). 


\section{O Diálogo de Saberes na práxis educativo-política do Zapatismo e do MST}

O MST e o Movimento Zapatista têm recuperado a memória histórica da resistência para se constituir como sujeito histórico-político, ou seja, se nutrem das sementes-palavras, dos métodos para avançar na consolidação de um projeto histórico de conhecimento e de um pensamento epistêmico dos povos indígenas e dos povos do campo como base do seu pensamento político. Nessa perspectiva, parto da premissa de que o Diálogo de Saberes constitui um seminário no cruzamento do conjunto de aprendizagens históricas, uma vez que constitui

La construcción colectiva de significación emergente, basada en el diálogo establecido entre personas o pueblos cuyas experiencias, cosmovisiones y maneras de conocer son especificas e históricamente diferentes, particularmente cuando se enfrentan a los nuevos desafios colectivos de un mundo cambiante. Dicho diálogo se apoya en el intercambio entre las diferencias y en la reflexión colectiva. A menudo, ello propicia la re-contextualización y la re-significación, lo cual da lugar a saberes y significados emergentes, que se relacionan con historias, tradiciones, territorialidades, experiencias, procesos y acciones de los distintos pueblos. Las nuevas y colectivas comprensiones, significancias y saberes, pueden llegar a constituir la base para acciones de resistencia colectivas y para la construcción de procesos nuevos (MARTÍNEZ-TORRES; ROSSET, 2014, p. 982).

O Diálogo de Saberes incide diretamente em três planos, a saber: na formação do sujeito histórico-político, aqui representado pelo yo-coletivo Zapatista e o eu-coletivo Sem Terra; no projeto histórico de conhecimento que deriva do projeto educativo-político, ao demarcar as raízes teórico-epistêmicas que darão forma e conteúdo ao processo de teorização desde-com-para os movimentos sociais e, por fim, na própria práxis pedagógica articulada pelos movimentos, isto é, nas pedagogias críticas que mediam o processo formativo.

Vejamos alguns referentes epistêmicos centrais para a gênese do yo-coletivo Zapatista ${ }^{16}$ : el Popol Wuj - livro sagrado dos povos k'iche maya da

${ }^{16}$ Utilizarei a palavra "eu” em espanhol - yo - para reforçar essa apropriação epistêmica na perspectiva dos Zapatistas. 
Guatemala, conhecido como Livro dos Conselhos ou Livro da Comunidade - constitui um dos seus principais referentes identitários dos povos indígenas da América Central e do México. Para estes povos, a história oral tem sido a forma de transmissáo dos saberes, das experiências e de todo o conhecimento acerca da vida e de si mesmos como comunidades. Conforme Recinos (1982, p. 9), os povos originários do México e da Guatemala "lograron conservar sus historias y otros escritos por medio de pinturas en lienzos. Había cronistas e historiadores que conocían las historias acerca de los orígenes [...] y que la transmitían por medio de la historia oral o por medio del arte pictográfico". Igualmente havia a contagem do tempo, a forma de nomear as crianças, ademais do papel social dos sonhos, agouros e superstiçôes. A maneira como tem sido apropriado e difundido o legado cultural, linguístico e político do Popol Wuj expressa a conjugação de diferentes elementos na recuperação e fortalecimento da identidade sociocultural e na conformação de um sujeito histórico-político. O Popol Wuj constitui um referente epistêmico, pedagógico e político central no pluralismo das comunidades mayas, e dialoga dialeticamente com outras culturas e resistências políticas da América Latina. ${ }^{17}$

No campo discursivo e literário, o coração místico do Zapatismo se expressa na figura literária do Velho Antônio e seus contos, relatados pelo Subcomandante Insurgente Marcos. A figura metafórica do Velho Antônio remete a duas referências diretas do Popol Wuj: a primeira, de raiz maya-quiché, o "velho" faz referência "à avó e ao avô", o Ixpiyacoc e Ixmucané (que na língua maya significa velho ou velha - ixnuc), os amparadores, protetores, narradores de tudo o que é o princípio da vida e o princípio da história. A segunda, de raiz tolteca-mexicana, reporta a seus equivalentes, os deuses mexicanos Cipactonal e Oxomoco, responsáveis pela invenção da astrologia judiciária e o calendário, com sua própria contagem do tempo. O referente epistêmico do Velho Antônio nos permite adentrar na polissemia cultural e simbologia maya e conhecer as interfaces do encontro de dois mundos: o indígena e o mestiço ou, nas palavras de Fernanda Navarro (2011), do mexicano com sua memória.

Um segundo referente no processo de recuperação do yo-coletivo $\mathrm{Za}$ patista se vincula à cosmovisão, a cultura e a matriz linguística maya, e que

${ }^{17}$ Existe uma série de documentos elaborados pelo movimento de resistência cultural na Guatemala, os quais apresentam princípios ético-filosóficos ancorados no Popol Wuj. Para um aprofundamento, sugiro a tese de doutorado de Almaguer (2015). 
situa o lugar do yo (eu) e do nosotros (nós) na racionalidade indígena. Um exemplo é a palavra maya tseltal p’ij yo'tan - é único teu coração que pressupóe uma autonomia pessoal, do ser como único na sua singularidade, mas também é interpretada como um processo de integração coletiva, de caráter comunal e de capacidade para alcançar consensos (PAOLI, 2003). Um segundo exemplo está conformado pela desinência da língua maya tojolabal tik - nosotros (nós) que expressa uma identidade coletiva e não individual, isto é, uma intersubjetividade comunitária (LENKERSDORF, 2005).

Um terceiro exemplo da recuperação do yo-coletivo, como sujeito coletivo no processo de construção do conhecimento, o articula três concepçóes chaves da língua maya tseltal: o o'tan - coração, o stalel e o ch'ulel - alma-espírito-consciência. López-Intzín (2013) afirma que: "en la cultura maya-tseltal no sólo surge y pasan por la mente las reflexiones, los pensamientos y saberes, también emanan del corazón y éste se vuelve el centro más importante en la cosmovisión y pensamiento nuestros. Portanto, tudo se "coraçona"” ${ }^{18}$. O o'tan constitui um conceito central na cultura e no posicionamento dos povos mayas tzeltales, como núcleo comum de sua cosmovisão. Dele se derivam percepçóes acerca da vida e da nossa forma de ser no mundo que se orienta a partir de uma lógica enraizada no Yajyel-snopel ya'yel-sna'el: sentir-pensar - sentir-saber (LÓPEZ-INTZÍN, 2013).

Por sua parte, o MST recupera seus referentes epistêmicos do legado histórico da resistência negra e das insurgências camponesas no Brasil, no Período Colonial, momento de expropriação de terras sem precedentes e de consolidação do grande latifúndio no Brasil (FERNANDES; STÉDILE, 2004). Também daquelas prévias ao período da Ditadura Militar, como as Ligas Camponesas, todas elas em defesa do território, da terra, da reforma agrária e do ethos identitário com o campo. Uma semente-palavra central para o MST é o conceito de organicidade, "uma palavra

${ }^{18}$ Em Barbosa (2016a), aprofundo essa análise com relação à construção do Paradigma Epistêmico dos povos indígenas e dos povos do campo, que emerge em contraposiçáo à imposição do paradigma moderno ocidental. Nele argumento como os movimentos sociais latino-americanos avançam na elaboração de uma teoria enraizada na relação razão-emoção, sentir-pensar, posicionamento que refuta a afirmativa da supremacia da razão sobre as emoções e sentimentos, base do conhecimento científico moderno. 
que criamos para designar a relação que deve ter uma parte da nossa organização com as demais partes. Entretanto, não pode ser uma relação teórica, mas física, prática e mística” (MST, 2001, p. 30-31).

O sentido epistêmico do conceito de organicidade está presente na narrativa política do MST, no conjunto de documentos e materiais didáticos utilizados na formação educativo-política dos seus quadros. Em um dos documentos utilizados nos cursos de formação política, o MST apresenta a centralidade da organicidade no processo de organizaçáo política do seu eu-orgânico como Movimento (MST, 2001, p. 22):

\begin{abstract}
A organicidade tem, ao mesmo tempo, a função de transformar o movimiento de massa, diminuindo sua espontaneidade e, por outro lado, garantir sua permanência histórica. Por tal razão, a organicidade tem o poder de, em qualquer momento, colocar a massa em movimiento, como também mantê-la agrupada por meio dos núcleos.
\end{abstract}

Por outro lado, o MST e o Zapatismo são inspirados pelos princípios da Teologia da Libertaçáo, da Teologia Indígena, ademais dos aportes teórico-políticos de revoluçóes latino-americanas, como a Revolução Mexicana, Cubana e Sandinista, as duas últimas inspiradas pelo marxismo-leninismo e o maoísmo, matrizes teóricas igualmente presentes na identidade política nas origens do MST (FERNANDES; STÉDILE, 2004) e do EZLN (LEYVA-SOLLANO, 1994; LE BOT, 1997). A consigna a terra é de quem nela trabalha, de Emiliano Zapata, sintetiza o horizonte político comum a ambos os movimentos: terra, liberdade e justiça.

Com base na síntese dos fios que tecem o Diálogo de Saberes na conformação do yo-coletivo Zapatista e do eu-orgânico Sem Terra, podemos inferir que o processo de construção do conhecimento na sua práxis educativo-política prescinde dos mesmos elementos epistêmicos que lhes dá identidade cultural e política. Nas escolas autônomas Zapatistas, por exemplo, é comum serem utilizados como material didático os Contos do Velho Antônio, ademais de outros contos conhecidos nas comunidades e que estão transpassados por referentes epistêmicos do Popol Wuj e da cosmogonia e cosmovisão maya. Os relatos do Velho Antônio tecem a sabedoria maya presente nos seus mitos e lendas com uma racionalidade própria dos povos indígenas daquela região e que dá o tom do ser-estar-sentir no mundo. Um dos livros utilizados, Arte en 
Rebeldia, traz a história dos homens e mulheres verdadeiros, em alusão ao mito fundacional do Popol Wuj, os homens do milho. ${ }^{19}$

Igualmente utiliza das imagens pictográficas pré-colombianas, como as pirâmides mayas, para abordar conteúdos de etnomatemática, da história de seus ancestrais, de geografia, das linguas mayas, da politica. De igual maneira, nas escolas autônomas e nos outros espaços das comunidades Zapatistas estão repletos de murais que evidenciam o Diálogo de Saberes. Para as e os Promotores de Educação responsáveis pela elaboração coletiva do livro, "los murales explican nuestra lucha, nuestro trabajo y nuestra historia. Ellos nos recuerdan nuestra dignidad y son nuestra memoria. Ellos expresan nuestro arte" (EZLN, s/f, p. 10). Para eles, os murais são considerados zapatistas porque "explican y dibujan la lucha, la historia y los símbolos zapatistas" (EZLN, s/f, p. 23).

O livro Arte en Rebeldía aborda a dimensão política da arte e consegue interpelar a histórica separação entre trabalho manual, trabalho intelectual e a dimensão criativa do ser humano, reflexão presente no processo educativo realizado nas escolas autônomas Zapatistas. Nessa direção, expressa uma linguagem atravessada pela dimensão intersubjetiva das línguas mayas e que "[...] atañe a la relación entre pensamiento-lenguaje-mundo y acción” (NAVARRO, 2011, p. 5). Para el Comandante Zebedeo $(2007, \mathrm{~s} / \mathrm{p})^{20}$ :

Los objetivos de la educación zapatista es que fortalezca nuestra cultura, lengua, la educación en nuestra propia familia, el colectivismo, la unidad, la disciplina, el compañerismo, aprender a resolver la necesidad de nuestros pueblos, el respeto a nuestras culturas, a defendernos con dignidad, nos enseñe a trabajar, que una el trabajo a la vida, a nuestra madre naturaleza [...] El objetivo de nuestra educación es que todos entiendan la situación en que vivimos.

${ }_{19} \mathrm{O}$ mito os homens do milho constitui no mito fundacional do Popol Wuj para contar a origem da humanidade. No livro Arte en Rebeldía, encontra-se no "Tema 5 - História del Arte", seguido do nome maíz (milho) em tseltal - ixim - e da citação extraída do Livro dos Conselhos.

${ }^{20}$ Radio insurgente. Programas Especiales. Disponível em: <http://www.radioinsugente. org/index.php?name=prgramas_especiales $>$. 
Por sua vez, o Diálogo de Saberes igualmente se faz presente em toda a práxis educativo-política do MST. Uma primeira expressão é a chamada mística que se realiza a cada dia de jornada educativa e de luta política, compreendida como momento da ritualização dos valores do MST (GONZÁLEZ-CASTELLS, 2002), entre eles, o da identidade do homem e da mulher do campo e o da memória da resistência camponesa e latino-americana. Remete a uma dimensão interpretativa da luta política por meio da sensibilidade e de uma polissemia simbólica para expressar um conjunto de temas e sentimentos que tem uma relação direta ou indireta com a histórica resistência camponesa e a centralidade da luta pela terra e pela reforma agrária popular. Outras duas noçóes nesse processo de interiorização dos valores e princípios do MST são: a consciência social e política própria do marxismo, do latino-americanismo, do internacionalismo e a dimensão da humanidade e da comunhão da história vivida pelo homem e a mulher do campo, tradição política da Teologia da Libertação (GONZÁLEZ CASTELLS, 2002; BARBOSA, 2015b).

O MST tem se dedicado à produçáo de documentos e materiais didáticos próprios para embasar teórica e pedagogicamente suas experiências educativas. Por exemplo, os Boletins de Educação apresentam a concepção de educação, pedagogia e escola para o MST, além da sistematização de suas experiências educativas em acampamentos e assentamentos do Movimento. Com relaçáo a práxis pedagógica, o MST recupera os fundamentos da Pedagogia Socialista e da Educação Popular, sobretudo aquelas elaboradas por Makarenko, Pistrak, Guevara e Paulo Freire.

Uma das grandes colaboraçóes do MST e do conjunto dos movimentos vinculados à Via Campesina Brasil foi a elaboração do Dicionário da Educação do $\mathrm{Campo}^{21}$, que reúne um conjunto de 113 conceitos provenientes de um Diálogo de Saberes entre os aportes da teoria crítica e do conjunto de experiências e saberes socialmente construídos no âmbito da resistência camponesa no Brasil. Os conceitos estão organizados em quatro eixos que dão conta da dimensão política de elaboraçáo do dicionário: campo, educação, políticas públicas e direitos humanos. Um aspecto fundamental do Dicionário de Educação do Campo consiste em que os conceitos são uma elaboração própria dos movimentos sociais. Expressam

${ }^{21}$ Participaram um expressivo número de militantes de movimentos sociais, além de pesquisadores de diferentes universidades brasileiras, num total de 107 autores. 
um olhar teórico-epistêmico e político acerca do fenômeno da Educação do Campo, de seus princípios filosóficos e pedagógicos, ademais de uma série de conceitos e categorias de análise diretamente relacionadas com a luta pela terra, pela reforma agrária e pelo direito à educação para os povos do campo no Brasil.

É vasta a produçáo teórica dos militantes do MST que ocupam o latifúndio do saber representado pela universidade, os cursos de graduação e pós-graduação ${ }^{22}$. Nessa direção, avança a elaboração teórica relacionada à concepção da Educação do Campo, Pedagogia do Movimento, Agroecologia, Diversidade Sexual, Gênero e Comunidade LGBT Sem Terra, Infância e Juventude Sem Terra, Reforma Agrária, para citar algumas temáticas debatidas com profundidade teórica e política pelo Movimento.

Pelo exposto, o MST considera que a educação "não é sinônimo de escola. Ela é muito mais ampla, porque se refere à complexidade do processo de formação humana, que tem nas práticas sociais o principal ambiente de aprendizagem do ser humano. (MST, 2005, p. 233). Para o MST, a construção de um projeto de Reforma Agrária Popular não se consubstanciaria sem a ruptura com o "latifúndio do analfabetismo e da educação burguesa, fazendo a Reforma Agrária também do saber e da cultura” (MST, 2005, p. 31).

\section{Seguir o caminhar... perguntando, escutando, teorizando...}

Afirma o Subcomandante Insurgente Marcos (2007, p. 322-323):

Entender lo que decimos, hacemos y haremos, es imposible se no se siente nuestra palabra. Yo sé que los sentimientos no tienen cabida en la teoría, cuando menos en la que ahora anda a los tropiezos. Que es muy difícil sentir con la cabeza y pensar con el corazón. [...] para nosotros, nosotras las zapatistas, el problema teórico es un problema práctico. No se trata de promover el pragmatismo o de volver a los origenes del empirismo, sino de señalar claramente que las teorias no sólo no deben aislarse de la realidad, sino deben buscar en ellas los mazos que a veces son necesarios cuando se encuentra un callejón sin salida conceptual.

22 Em Barbosa (2015a), apresento a trajetória do MST na demanda pela democratização do acesso à educação superior para os povos do campo no Brasil. 
A crítica realizada na citação destaca as ausências de uma teoria que, ainda, se distancia de pensar a construção do conhecimento em estreito vínculo com a realidade dinâmica, em movimento permanente e que, por tal razão, inova seus marcos reflexivos, o posicionamento do sujeito histórico-político e sua proposta ante as contradiçóes de ordem cultural e político-econômica. Entretanto, o MST e o Zapatismo são exemplos concretos da emergência de uma teoria própria dos movimentos sociais (BARBOSA, 2013) ${ }^{23}$, uma teoria coraçonada, que semeia sementes-palavras como conceituaçáo própria, referendada por um olhar epistêmico que revela um processo de escuta permanente da palavra do yo-coletivo Zapatista, do eu-orgânico Sem Terra, sujeitos coletivos construtores de conhecimento.

No projeto histórico de conhecimento que se anseia edificar com a Educação Zapatista e a Educação do Campo, os sujeitos educativos são a comunidade, as crianças Zapatistas e os Sem Terrinha, a juventude, os anciãos. Cada um deles é parte do processo educativo-político; a partir de sua palavra se amplia o sentido epistêmico-político da teoria coraçonada. Em termos pedagógicos, abre-se caminho para a emergência de saberes que se transformam em conceitos políticos incorporados à identidade política e a sua agenda de luta.

Gostaria de destacar que o processo de construção do conhecimento desdelcom/para os movimentos sociais toma dois elementos importantes: uma resistência linguística, isto é, de fortalecimento da dimensão epistêmica da língua materna e da racionalidade intersubjetiva (para o caso do Zapatismo) e de recuperaçáo da cultura, dos valores e do ethos identitário com a terra e o território. Em segundo lugar, uma geopedagogia do conhecimento (BARBOSA, 2014; 2015a), relação entre a práxis pedagógica e os elementos de ordem sociocultural e do território que conformam o conjunto de saberes e a multiplicidade de elementos constitutivos da práxis política, os quais incidirão na construção do conhecimento no marco da resistência.

Para terminar esta reflexão, considero que a Pedagogia da Milpa ${ }^{24}$ (BARBOSA; GÓMEZ-SOLLANO, 2014; BARBOSA, 2016a) póe em

23 Parece-me importante mencionar a Gunderson (2013) e sua análise acerca das origens intelectuais do Zapatismo e o processo de consolidação de uma teoria revolucionária.

24Faço alusão à milpa, do náhuatl: milli (parcela cultivada) e pan (em cima), agrossistema mesoamericano destinado ao plantio de feijão, jerimum, milho e pimenta. Nas comunidades indígenas sempre tem uma milpa. No SERAZ, a milpa é um dos espaços educativos das crianças e dos jovens. 
movimento dialético as sementes-palavras que brotam do Diálogo de Saberes. Expressa o sentido epistêmico do ato educativo, por articular diferentes elementos na formação educativa e política do sujeito histórico-político, própria de uma cosmovisão, de uma língua, de uma cultura, de outra racionalidade derivada de outras epistemes na elaboração teórica. $\mathrm{Na}$ Pedagogia da Milpa, o processo educativo está atravessado pelos saberes ancestrais, pela identidade cultural, pelas consignas políticas, mas também pela poesia feita canção, pela pintura, a arte cênica e iconográfica, entre outras manifestaçóes da arte insurgente, rebelde, subversiva, que também são seminários na construção e prática de conhecimento.

Um processo de re-apropriação cultural que termina por fortalecer a organização coletiva e política e sua capacidade de forjar um projeto histórico de conhecimento feito sementes-palavras, sempre articulado a um ser-estar, um sentir-pensar, isto é, um posicionar-se de forma coraçonada. $\mathrm{Na}$ nossa caminhada como educadoras e educadores e pesquisadores-ativistas, estejamos atentos ao Diálogo de Saberes que emerge das experiências educativas e das pedagogias alternativas dos movimentos sociais.

\section{Referências}

ALMAGUeR, R. X. R. El Popol Wuj y sus traducciones por mayahablantes. Memoria histórica y resistencia cultural en Guatemala, 1970-2014. Tese (Doutorado)- Programa de Posgrado en Historiografía. Universidad Autónoma Metropolitana - UAM: 2015.

ARROYO, M. et. al. (org). Por uma Educaçáo do Campo. Petrópolis: Vozes, 2004 .

BARBOSA, L. P. Educação do Campo [Education for and by the countryside] as a political project in the context of the struggle for land in Brazil. The Journal of Peasant Studies, p. 1-26, 2016.

Educación, resistencia y conocimiento en América Latina: por una teoría desde los movimientos sociales. Revista De Raíz Diversa, México: UNAM, vol. 3, no 6, p. 45-79, 2016, jul-dic., 2016.

. El principio de la autonomía y la praxis de la libertad en la Educación Rebelde Autónoma Zapatista. Revista del Centro Telúrico de Investigaciones Teóricas - CISMA. no 6. 2015. 
BARBOSA, L. P. "Educação do Campo, movimentos sociais e a luta pela democratização da Educação Superior: os desafios da universidade pública no Brasil”. In: ACOSTA A. et. al. Los desafíos de la universidad pública en América Latina y el Caribe. Buenos Aires: CLACSO, 2015a.

. Educación, resistencia y movimientos sociales: la praxis educativopolítica de los Sin Tierra y de los Zapatistas. Ciudad de México: LIBRUNAM, 2015b.

"Educación y lucha autonómica en la Voz Zapatista: aportes de la Pedagogía del Sentir-Ser, Sentir-Pensar y Sentir-Saber". Dossier Movimientos Sociales y Educación. Revista Educación y Cultura. Colombia: FECODE, no 105, 2014.

Educación, movimientos sociales y Estado en América Latina: estudio analítico de las experiencias de resistencia contra-hegemónica en Brasil y México. Tese (Doutorado) - Programa de Posgrado en estudios latinoamericanos. UNAM. Néxico, 2013.

BARBOSA, L. P.; GÓMEZ-SOLLANO, M. La Educación Autónoma Zapatista en la formación de los sujetos de la educación: otras epistemes, otros horizontes. Revista Intersticios de la Política y de la Cultura. Intervenciones latinoamericanas. Universidad Nacional de Córdoba, v. 3, nº 6, 2014.

CABEZAS, Omar. A montanha é algo mais que uma imensa estepe verde. São Paulo: Expressáo Popular, 2008.

CALDART, R. Pedagogia do Movimento Sem Terra. São Paulo: Expressão Popular, 2004.

CARBONI, F.; MAESTRI, M. A linguagem escravizada: língua, história, poder e luta de classes. São Paulo: Expressão Popular, 2012.

CASTELLANOS, R. Oficio de tinieblas. México: Editorial Planeta, 1962.

CUSICANQUI, S.R. Oprimidos, pero no vencidos. Luchas del campesinato Aymara y Qhechwa (1900-1980). La Paz: La Mirada Salvaje, 2010.

EZLN. Crónicas intergalácticas - EZLN. Primer Encuentro Intercontinental por la Humanidad y contra el Neoliberalismo. Chiapas: Estampas Artes Gráficas, 1996.

FERNANDES, B.M., STÉDILE, J.P. Brava Gente. Historia y lucha del Movimiento de los Sin Tierra en Brasil. La Habana: Editorial Popular, 2004.

FREIRE, P. Pedagogia do Oprimido. Rio de Janeiro: Paz e Terra, 1987. 
GRAMSCI, A. Literatura e vida nacional. Rio de Janeiro: Civilização Brasileira, 1987.

PROA, 2011.

La alternativa pedagógica. Caracas: Editorial Laboratório Educativo.

GONZÁLEZ-CASTELLS, A. N. "A ritualização dos valores do MST". In:

VENDRAMINI, C. (Org.). Educaçáo em Movimento na luta pela terra.

Florianópolis, NUP/CED, Série Pesquisas, 2002.

GUEVARA, E. Obras escogidas. Santiago de Chile: Editora Digital por Resma, 2004.

GUNDERSON, C. The provocative cocktail: intellectual origins of the Zapatista Uprising. Tesis (Doctorado) - Faculty in Sociology, University of de New York, 2013.

KOLLING, E. et. al. Educaçáo do Campo: Identidade e Políticas Públicas - Por uma Educação do Campo. Brasília, 2002.

LANDER, E. A colonialidade do saber: eurocentrismo e Ciências Sociais. Buenos Aires: CLACSO, 2005.

LE BOT, Y. Subcomandante Marcos - el sueńo Zapatista, 1997.

LENKERSDORF, C. Los hombres verdaderos. Voces y testimonios tojolabales. México, Siglo XXI, 2005.

LEYVA-SOLLANO, X. Identidad étnica, política y religión en la región del conflicto", en Chiapas Hoy, Análisis antropológico y social. México, INAH, 1994.

LÓPEZ-INTZÍN, X.. "Ich'el ta muk': la trama en la construcción del Lekil Kuxlejal (vida plena-digna-justa)”. In: MÉNDEZ-TORRES et. al. (coordinación). Senti-pensar el género. Perspectivas desde los pueblos originarios. México: Red-IINPIM/Red Feministas Decoloniales, 2013.

MARTÍNEZ-TORRES, M.E.; ROSSET, P. Diálogo de sabers. In: La Vía Campesina: food sovereignty and agroecology. Journal of Peasant Studies, v. 41, n. 6, 2014.

MST. Escola Itinerante do MST: história, projeto e experiências. Cadernos da Escola Itinerante - MST. Ano VIII, no 1 - abril de 2008. Curitiba: Setor de Educação do MST / Secretaria de Educação do Estado do Paraná / Coordenaçãao da Educação do Campo, 2008.

. "Dossiê MST - Escola. Documentos e estudos 1990 - 2001", em

Caderno de Educação, n. 13, 2. ed., São Paulo: Expressão Popular, 2005. 
MST. Somos Sem Terra. Para soletrar a liberdade, em Caderno do Educando, no 2, Rio Grande do Sul, Veranópolis: ITERRA, 2001.

NAVARRO, F. Prólogo. In: Subcomandante Insurgente Marcos. Relatos del Viejo Antonio. México: Ediciones Rebeldía, 2011.

PALUDO, C. Educação popular em busca de alternativas. Porto Alegre: CAMP, 2001.

PAOLI, A. Educación, autonomía y lekil kuxlejal. Aproximaciones sociolingüísticas a la sabiduría de los tzeltales. México: Siglo XXI, 2003.

PONCE, A. Educación y lucha de clases. Bogotá: Editor Rojo, 1920.

PUIGGRÓS, A. La educación popular en América Latina. Orígenes, polémicas y perspectivas, Buenos Aires: Miño y Dávila Editores, 1998.

. Presencias y ausencias en la historiografía pedagógica latinoamericana. In: CUCUZZA, H. R (Comp.). Historia de la educación en debate. Buenos Aires: Mińo y Dávila, 1996. p. 91-119.

PUIGGRÓS, A; GÓMEZ-SOLLANO, M. La educación Popular en América Latina. México: Ed Caballito, 1986.

QUIJANO, A. "Colonialidad del poder, cultura y conocimiento en América Latina”. In: CASTRO-GÓMEZ, S. et. al. (eds.). Pensar (en) los intersticios. Teoría y práctica de la crítica poscolonial. Bogotá: Instituto de Estudios Sociales "Pensar", Pontificia Universidad Javeriana, 1999.

RECINOS, A. Popol Vuh - las antiguas historias del Quiché. Guatemala: Piedra Santa, 1982.

RIBEIRO, M. Educação Popular: um projeto coletivo dos movimentos sociais populares. Perspectivas, Florianópolis, v. 26, n. 1, p. 41-67, 2008.

RODRIGUEZ, L (Org.). Educación popular en la historia reciente en Argentina y América Latina. Aportes para balance y prospectiva. Buenos Aires: APPeAL, 2013.

SOLLANO, M. G. La Educación Popular en América Latina. México: Ed. El Caballito, 1986.

Subcomandante Insurgente Marcos. "Ni el centro, ni la periferia... Parte VII (y última) - sentir el rojo. El calendario y la geografía de la guerra”, Primero Coloquio Internacional in memoriam Andrés Aubry. San Cristóbal de las Casas: Universidad de la Tierra, Rebeldía, 2007. 


\section{POLÍTICAS PÚBLICAS EDUCATIVAS: ACTORES, TIEMPOS Y CONTEXTOS}

Paulina Elena Villasmil Socorro ${ }^{1}$

Yo no quiero parecerme a los árboles, que echan raices en un lugar, sino al viento, al agua, al sol y a todas las cosas que marchan sin cesar.

(Simón Rodríguez)

\section{Introducción}

Las palabras del maestro Simón Rodríguez, máximo referente de la pedagogía libertaria nuestroamericana, incorpora a la educación, a la pedagogía y al docente el carácter mutable, ese que define Walter Kohan como la errancia contenida en la frase robinsoniana "o inventamos o erramos". Contrario al hecho inmutable de la división social del trabajo que permea a los sistemas escolares, para Simón Rodríguez la educación, en tanto fenómeno político y de carácter estratégico (P. Freire y L. B. Prieto Figueroa) para la construcción social está siempre en movimiento, es un viaje permanente de descubrir, comprender, comunicar y transformar, ese carácter transformable que le da sentido a la pedagogía está enlazado al cambio social.

En el contexto latinoamericano, la construcción de una historia de la educación, necesariamente debe estar articulada a la historia del cambio social como un factor determinante en la arquitectura de esa historia (BIGOTT, 2013). Pero para un análisis sobre el devenir de la educación, como hecho social y proceso que genera cambio social, se hace necesario poner la atención en la cuestión de la influencia del capitalismo financiero mundial y su impacto en las políticas públicas educativas en los países de América Latina.

1 Universidad Nacional Experimental "Rafael María Baralt"; Movimiento Pedagógico Revolucionario, Maracaibo - Venezuela. 


\section{El siglo de la gran ocupación}

Las últimas dos décadas del siglo XX constituyeron la profundización de las políticas neoliberales establecidas por la intervención imperial estadounidense y de la Unión Europea. El discurso que acompañaba las políticas educativas era el mismo que justificaba la prescripción de las responsabilidades del Estado en la salvaguarda de derechos sociales y la emergencia de la privatización bajo la égida de la ineficiencia estadal en la gestión de políticas de empleo, vivienda, salud, educación y servicios públicos. Esta tendencia sólo fue posible gracias al andamiaje político construido en los primeros cincuenta años del siglo que nos antecede, de configuración de repúblicas dependientes, con rupturas inacabadas del sustrato colonial y castigadas por los regímenes dictatoriales que sometieron al continente desde México y el Caribe hasta el Atlántico Sur. Posteriormente, en las últimas dos décadas del siglo $\mathrm{XX}$, los gobiernos democráticos implementaron políticas reformistas subordinadas a los grandes capitales financieros que desplegaron su dominio a través de las organizaciones globales supranacionales (BM, FMI, BID, OCDE, entre otras) las cuales, dejaron la impronta de una desigual estratificación social. $Y$ es que no puede ser de otra manera, con el mismo talante con que se acrecienta el poder del capital, lo hace la barbarie y la exclusión.

\section{Usurpan la tierra, saquean sus recursos, aniquilan la cultura}

El proceso socio-político latinoamericano del siglo XX tuvo sus singularidades pero también sus coincidencias, en tanto que el objetivo de la intervención norteamericana en esta área territorial era el mismo, el del aseguramiento de lo que Karl Haushofer (Alemania 1869 - 1946), denominó el "espacio vital". En el caso venezolano, el modelo capitalista se va definiendo al fragor de la explotación petrolera. La actividad extractivista y rentística petrolera constituyó un proceso de implantación de una cultura de la dependencia que supuso la negación de las raíces culturales originarias a través de la colonización, no sólo económica sino lo que es más grave, ideológica. Este proyecto de conquista que fue tomando cuerpo desde los primeros enclaves desplazó al modelo productivo agropecuario, y con él, al campesinado y su fuerza como grupo social e introdujo manifestaciones culturales diferentes a las autóctonas, Rodolfo Quintero 
(2011, p. 39) explica que la explotación petrolera de inicios del siglo XX generó toda una plataforma cultural a la que denominó "la cultura del petróleo".

La cultura del petróleo deja huellas grandes y profundas; forma «hombres creole» y "hombres Shell», nacidos en territorio venezolano pero que piensan y viven como extranjeros; hombres de las compañías y para las compañías, personas antinacionales. Expresión de un mestizaje repugnante, resultado de una política de «relaciones humanas» aplicada por los colonialistas. Obra de los monopolios internacionales animadores de aquella cultura.

Este proceso de transculturación no sólo tuvo como soportes a las democracias representativas dirigidas por una clase política entreguista y genuflexa a los poderes de las transnacionales norteamericanas y europeas y una oligarquía mercantilista y parasitaria del financiamiento estadal, sino que tuvo un apoyo fundamental en sistemas educativos con sólidos cimientos conceptuales positivistas y conservadores desde el punto de vista ideológico. Las políticas educativas situadas desde este posicionamiento epistemológico - tal como lo explican las teorías de la reproducción en las que se analiza cómo funcionan los dispositivos ideológicos del Estado, cuyo punto de partida son los trabajos de L. Althusser y los que le siguieron como P. Bourdieu y J. C. Passeron y; C. Baudelot y R. Establet, por mencionar algunos - dieron viabilidad a los objetivos de una educación que, además de estar al servicio del desarrollo económico y de la nueva estructura social originada con la explotación petrolera, también causó el vaciamiento de su contenido social, político, histórico - cultural y emancipador, tanto, aquel ideado durante la construcción de la república de base rodrigueana; como, el propuesto por el maestro Luis Beltrán Prieto Figueroa y los precursores de la Escuela Nueva en Venezuela, defensores del Estado Docente, en el marco de las luchas en contra de la dictadura para la consolidación de la democracia y la soberanía.

De la misma forma, en el resto de los países de Latinoamérica el modelo educativo impuesto desde los centros de poder es parte importante del engranaje que estructura el sistema mercantilista neoliberal. La acción expansiva de un capitalismo extractivista de materias primas en todo este vasto territorio que nuestros habitantes originarios llamaron Abya Yala, sirvió para despojarlos de recursos estratégicos (biodiversidad, reservas 
acuíferas, minerales e hidrocarburos) e imprimir una huella de transculturación y marginalidad que asegurase el carácter de territorios vulnerables y dependientes.

\section{Las políticas globalizantes de los organismos internacionales}

Durante los años 80 y 90, se establecen, a través de diversos organismos para la integración regional, una serie de políticas de carácter globalizantes y coordinadas con los acuerdos y tratados económicos internacionales, convenidos por la CAN, el MERCOSUR, ALADI, BID, BM, FMI, OCDE, entre otras. Ovidio Charles Van Glover (2012) explica que en dichos tratados de integración, los fines de la educación están estrechamente vinculados con categorías como desarrollo, subdesarrollo, desarrollo sustentable, competitividad, propias de una semántica de la dominación, así mismo, en los discursos sobre las reformas educativas subyacen conceptos propios de un "colonialismo cultural/semántico que conforman los procesos discursivos y el régimen de verdad impuesto por la dominación” (GLOVER, 2010, p. 205). Por otro lado, las evaluaciones internacionales de calidad educativa, como las que realizan el Laboratorio Latinoamericano de la Calidad de la Educación (LLECE - UNESCO) o el Programa para la Evaluación Internacional de Alumnos (PISA - OCDE), intentan producir información estadística acerca de tópicos, en clave de estándares, que deben caracterizar una educación de calidad que acompañe el desarrollo para todos los países de la región:

PISA es diseñada y puesta en marcha por la OCDE, convirtiéndose su propuesta en el paradigma de la medición y estandarización educativa a nivel global. La direccionalidad estratégica de la política educativa suele ser decidida por el centro de poder del sistema mundo derivado del acuerdo de Bretton Woods (1944) (BONILLA, 2016, p. 10).

En este contexto y con el pretexto de coadyuvar a la consecución de las demandas de calidad, países como España vendieron sus reformas educativas de base neoliberal a los países de América Latina. Las reformas curriculares adoptadas como parte de las políticas públicas educativas giraron en torno a las ideas neoclásicas defensoras del concepto de sociedad 
educadora según el cual las regulaciones y orientaciones de los objetivos educacionales deben plantearlos la sociedad y no el Estado (S. CARVAJAL; P. VILLASMIL, 2014). Desde el plano pedagógico y organizacional se promueven los conceptos del constructivismo pedagógico y los proyectos pedagógicos de centro como forma de vincular a la escuela con su entorno comunitario, en un intento de búsqueda de respuestas a un modelo de escuela ya agotado. Estas reformas adoptadas por los gobiernos, más que reconocer las necesidades de transformación de una escuela vinculada a su comunidad, ocultaban su trasfondo privatizador, a través de lo que Mészáros (2009) denomina la "legitimación constitucional democrática" del Estado capitalista. Las reformas educativas que se sucedieron luego de la reunión de la Comisión Internacional sobre la Educación del Siglo XXI de la UNESCO, en 1996, eran contradictorias con sus propios fines, esta incongruencia entre las propuestas emanadas de los acuerdos internacionales y la práctica ha sido denunciada por Luis Bonilla (2016, p. 92) cuando plantea:

El cambio educativo suele venir en presentaciones de reformas y en algunos casos de revoluciones. A veces las reformas son lo más revolucionario posible en un momento histórico dado; en otros casos las reformas sólo intentan impedir revoluciones y contradicen la propia esencia etimológica de 'acción para volver a formar' reproduciendo las mismas políticas y prácticas que enuncian cambiar.

Las editoriales, organizaciones no gubernamentales, fundaciones y diversos entes benefactores con grandes capitales involucrados en el negocio de las reformas educativas, especialmente los relativos a las nuevas tecnologías para la comunicación e información, ponen los medios para materializar dichas reformas. Según el análisis de I. Mészáros (2008), las reformas educativas poco pueden dar respuestas a las exigencias sociales si están concebidas bajo los principios del capital por la contundente convicción de que este es incorregible.

Procurar márgenes de reforma sistémica dentro del marco del propio sistema del capital constituye una incongruencia. Por eso es necesario romper con la lógica del capital si queremos considerar la creación de una alternativa educativa significativamente diferente (MÉSZÁROS, 2008, p. 220). 


\section{La emergencia de una educación inclusiva}

Como producto de un proceso de luchas de organizaciones y movimientos sociales indoafroamericanos, de obreros, campesinos, de maestros, de mujeres, religiosos (como el de la teología de la liberación) y partidos políticos de izquierda, el siglo XXI se inaugura con la emergencia de gobiernos progresistas y de izquierda en algunos países de América del Sur como Brasil, Ecuador, Argentina, Venezuela, Bolivia y el intento reciente y frustrado de Paraguay, los cuales torcieron el rumbo privatizador y mercantilista de la educación y formularon políticas en favor de una educación pública e inclusiva que permitiesen construir otro orden social.

En Venezuela desde el ańo 1999, con el proceso de refundación del Estado en el marco de la Revolución Bolivariana se inicia también un proceso constituyente en el que todos los docentes del país debaten diversos temas de interés nacional. La Constituyente Educativa puso en discusión temas relativos a la calidad de la educación, el analfabetismo, la repitencia y deserción escolar, la cobertura, la gratuidad, el carácter público, el Estado Docente, la laicidad, la formación de los docentes, las condiciones socioeconómicas de los maestros, los sindicatos y el ejercicio del sindicalismo en educación, entre otros que sirvieron para dar cuerpo al Proyecto Educativo Nacional (PEN).

\section{Políticas Educativas de la Revolución Bolivariana}

El Proyecto Educativo Bolivariano (PEB), surge bajo los principios y normas de la Constitución de la República Bolivariana de Venezuela (CRBV) aprobada en referendo popular en el ańo 1999, en lo concerniente a las garantías del derecho a la educación y el valor de la educación pública. Este nuevo modelo plantea la gratuidad desde la educación inicial (0 años) hasta el nivel universitario y se reconocen los derechos educativos de sectores excluidos de los procesos de escolarización. La educación se asume como un derecho humano y deber social, de carácter público y gratuito, teniendo como principio ético y político la pertinencia y la equidad. En el PEB se expresa:

En este sentido, se concibe la educación desde la articulación de dos grandes mecanismos de innovación transformadora: los 
proyectos bandera y las misiones, cuyo desarrollo permite apreciar los logros que van dando paso al proceso de construcción de la nueva estructura del sistema educativo (MED, 2004, p. 11).

Uno de los principales principios que constituyen este proyecto es alterar la directriz neoliberal de las últimas décadas y recuperar la perspectiva del Estado Docente, tal como se expresa en la CRBV (1999) en el artículo siguiente:

La educación es un derecho humano y un deber social fundamental, es democrática, gratuita y obligatoria. El Estado la asumirá como función indeclinabe y de máximo interés en todos sus niveles y modalidades, y como instrumento de conocimiento científico, humanístico y tecnológico al servicio de la sociedad. La educación es un servicio público y está fundamentada en el respeto a todas las corrientes del pensamiento, con la finalidad de desarrollar el potencial creativo de cada ser humano y el pleno ejercicio de su personalidad en una sociedad democrática basada en la valoración ética del trabajo y la participación activa, consciente y solidaria en los procesos de transformación social, consustanciado con los valores de la identidad nacional y una visión latinoamericana y universal. El Estado con la participación de las familias y la sociedad, promoverá el proceso de educación ciudadana, de acuerdo con los principios contenidos en esta Constitución y en la Ley (Art. 102).

La propuesta de un modelo educativo diferente pretende la transformación de la escuela y del docente como proceso básico para la construcción de una nueva ciudadanía. En este proceso de definiciones participan los movimientos sociales surgidos desde las luchas magisteriales, estudiantiles, campesinas, obreras, indígenas, afrovenezolanas y de los movimientos de la teología de la liberación que datan del siglo XX y otros más recientes que nacen en el contexto de la Revolución Bolivariana, todos ellos con un compromiso claro con el modelo de educación emancipadora.

\section{Las Misiones Educativas: una política de educación para todos y todas}

Las misiones educativas representan una de las políticas de mayor impacto social por la ruptura que ha supuesto con el modelo de educación 
tradicional. Ellas se estructuran en tres tipos para atender diversas problemáticas derivadas de las dinámicas excluyentes del pasado:

Misión Robinson, cuya finalidad es erradicar el analfabetismo y brindar la posibilidad de culminar la educación primaria.

Misión Ribas, dirigida a aquella parte de la población que no pudo culminar sus estudios de educación secundaria.

Misión Sucre, cuya finalidad es la de brindar la posibilidad de profesionalización universitaria.

En todas las misiones educativas el componente del trabajo productivo para el desarrollo endógeno está presente con la finalidad de impulsar una nueva cultura productiva que aprecie los saberes autóctonos y ancestrales, que introduzcan valores de solidaridad y cooperación y potencie la organización comunitaria para la participación en la vida pública y la defensa de la soberanía en todas sus expresiones. El mayor logro alcanzado con la política de misiones educativas ha sido erradicar el analfabetismo y devolver la dignidad a millones de venezolanos excluidos del sistema educativo durante los anteriores cuarenta años de democracia representativa. Para el año 2005, la UNESCO declara a Venezuela territorio libre de analfabetismo. Hasta mayo del 2014, 2.683 .126 personas han sido beneficiarios de la Misión Robinson.

Gráfico 1 - Venezuela. Egresado de la Misión Ribas. Según sexo (2008-2013)

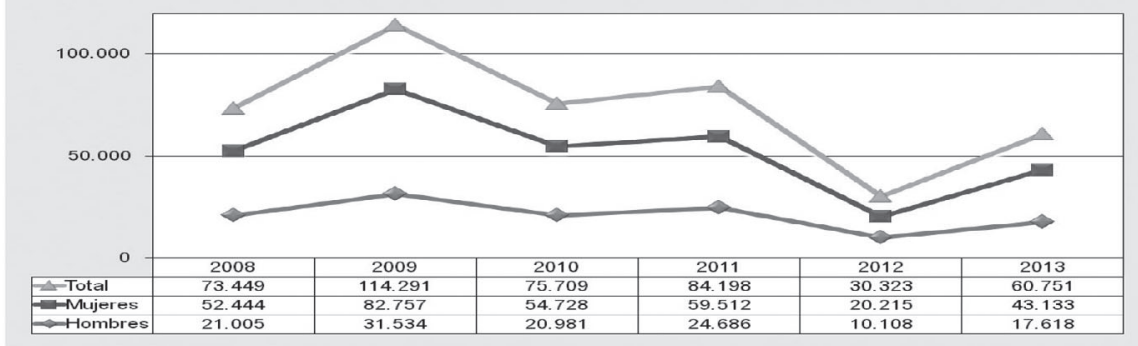

Fuente: Memoria y Cuenta 2012-2013, Ministerio del Poder Popular para la Fducación (MPPE). Proyecciones de Población según Censo 2011 , Instituto Nacional de Estadística (INE).

Realizado por: Coordinación de Estadísticas de Educación, Gerencia de Estadísticas Sociales (INE).

Otro de los logros importantes se muestra en las conquistas de los derechos de las mujeres a una educación sin discriminación de género. Según datos del Instituto Nacional de Estadísticas, en el caso de los egresados de la Misión Ribas, con la que se alcanza la educación secundaria, son las mujeres quienes concentran la mayor cantidad de egresados. 


\section{El trabajo docente}

Rolando Pinto Contreras (2014) al justificar la necesidad de hablar de una pedagogía crítica en América Latina explica que la praxis educativa tiene un tiempo y un espacio que la define, el docente que la hace posible también tiene un posicionamiento epistémico que se manifiesta en la forma de concebir y producir el conocimiento, tal situación le lleva a la toma de decisiones sobre qué enseñar, cómo enseñar y con qué finalidade. De allí que el momento presente que caracteriza la región latinoamericana demande una acción históricamente comprometida y políticamente decidida de los docentes, a la vez que pone nuevamente en el debate social y académico la cuestión del paradigma pedagógico y las relaciones de poder.

Las desgastadas fórmulas del taylorismo - conductismo que acompañaron los diseños curriculares ya no pueden dar respuestas a los complejos problemas sociales. La función pedagógica orientada al desarrollo de competencias para el trabajo es objeto de discusión por su insuficiencia para la formación de un sujeto que entienda y asuma el trabajo como instrumento para el "sumak kawsay", vocablo quichua que traducido al castellano significa el «buen vivir». Tal concepto trasciende el de estado de bienestar y constituye una filosofía de vida que no solo supera la idea de felicidad unida a la acumulación de bienes de capital, sino que impone un nuevo modelo civilizatorio que recupera las prácticas de vida ancestrales de los pueblos indígenas constituyéndose en el quiebre de lo que S. Castro Gómez y R. Grosfoguel (2007) han denominado la "colonialidad del poder". ${ }^{2}$

Según Carlos Lanz (2009), el apoyo que brindó la ciencia conductista al taylorismo y al fordismo, generaron una serie de problemas en los contextos escolares, como el fracaso escolar, que constituyeron verdaderas trampas del sistema educativo con su consecuente secuela de exclusión de las poblaciones estudiantiles más vulnerables desde el punto de vista económico y sociocultural. En este sentido el autor plantea:

2 Vale la pena revisar el artículo que escribe Magdalena León en el que conceptualiza ampliamente el paradigma del buen vivir, como ejemplo se cita el siguiente texto: "El paradigma del 'buen vivir' resulta convergente y se nutre de análisis y propuestas avanza- das ya desde hace décadas por la economía feminista y la ecologista, que han cuestionado las nociones de economía y riqueza en sus formas predominantes clásica y neoclásica, y que postulan la sostenibilidad ambiental y humana como centrales e indisociables" (LÉON; T. MAGDALENA, 2010, p. 105). 
[...] Encontramos que se postula un enfoque psicologista e individualista, el cual ubica las raíces de los problemas educativos en la persona, separada de su contexto sociocultural. De esta manera, el fracaso escolar no puede buscarse en la estructura social, en el Estado, en la escuela, etc., sino que tiene que ver - según este criterio - con la conducta positiva, la motivación al logro, ser proactivo, desarrollando la competitividad como valor (LANZ, 2009, p. 105).

Lanz (2009) explica que en el sistema educativo venezolano pueden constatarse la existencia de tres corrientes bajo las que se diseñaron los currículos y la acción educativa. Ellos son la corriente técnico - instrumental de base positivista, el paradigma interpretativo proveniente de la fenomenología y la corriente transformadora sustentada en la teoría crítica. Estos paradigmas han gravitado de manera simultánea, tanto en las propuestas elaboradas por la administración de la educación, como en la formación universitaria y en la praxis docente, lo cual ha generado verdaderas mezclas incongruentes con sus efectos en el débil anclaje social de la acción educativa, una evidencia de ello es la poca pertinencia de los proyectos educativos tanto institucionales (Proyectos Educativos Integrales Comunitarios - PEIC) como de los proyectos de aprendizaje en el aula.

El momento actual exige la rectificación de estos errores, no sólo de método o aplicación sino conceptuales, errores que tienen que ver con debilidades conceptuales sobre el trasfondo filosófico, político y pedagógico que encierran los paradigmas y los derroteros por donde debe transitar la educación en la realidad actual venezolana y de América Latina.

Tanto el enfoque técnico - instrumental, centrado en la acción de un especialista que elabora objetivos educacionales inamovibles, sujetos a la norma de lo administrativo, que desarrolla la estéril práctica de la tramitación burocrática; como el enfoque interpretativo que a pesar de que intenta fundamentar la acción didáctica en la comprensión del significado de las acciones de los individuos en su contexto social, dejan de lado el análisis de las relaciones de dominación presentes en la escuela y su impacto en las relaciones sociales escolares. Problemáticas de gran calado como la violencia que se presenta en las instituciones educativas no han podido ser explicadas y atendidas en su toda su complejidad bajo estos paradigmas, al contrario, la superficialidad de las interpretaciones sobre el tema de la violencia escolar ha velado temas de fondo relativos a las relaciones de poder intervinientes en la violencia presente en las escuelas. 
Como corolario, se plantea la corriente crítico - emancipadora que rescata el papel del docente como constructor de conocimiento, en oposición a las tendencias que limitan la acción docente a la función de facilitador u orientador, eufemismos con los que se ha pretendido sepultar la importancia de su acción en la transformación social.

Mucho se ha reflexionado sobre la responsabilidad social del trabajo docente para la formación del sujeto - epistémico social en el contexto de América Latina. Hacia lo que apunta el debate es a la formación de un docente que sea capaz de entender la acción pedagógica con una dimensión investigativa y vinculada, dicha acción, a la vida en el entorno más próximo del que hacer comunitario pero también en relación con el contexto nacional y global. Tal binomio investigación - acción, sirva para la comprensión de qué mundo se quiere construir y qué sujetos sociales lo deban preservar. Atilio Borón (2012), al explicar las relaciones de Estados Unidos con los países de América Latina plantea que el capitalismo y su fase superior, el imperialismo, siguen mostrando sus efectos más brutales en su intento por continuar editando su proyecto civilizatorio:

América Latina es una región depositaria de inmensos recursos naturales. Agua, petróleo, gas, minerales estratégicos, biodiversidad, agricultura y ganadería se encuentran altamente representados en nuestra región, frontera entre el Tercer Mundo y la mayor economía del planeta, Estados Unidos, cuya voracidad consumista, convierte a nuestra región en un poderoso imán que suscita el insaciable apetito del imperio (BORÓN, 2012, p. 113).

Pretender direccionar la educación por la ruta propuesta por el proyecto civilizatorio capitalista, de la escuela desvinculada del contexto comunitario, de la tarea y el examen, del libro y el pizarrón - hoy la laptop y el videoproyector -, de asignaturas atomizadas, una escuela sin sentido para los alumnos, porque los niega y los moldea a la medida justa en que los haga casi invisibles, sería insistir torpemente en salvar un modelo que ya no tiene lugar ni tiempo en la realidad actual. La pedagogía crítica emancipadora pone al descubierto tal modelo, al plantear la movilización y agitación de los docentes, su protagonismo en la participación en la vida pública y su capacidad organizativa como motor de transformación social.

En Venezuela, la corriente de la educación crítica emancipadora asumida por colectivos de educadores y organizaciones sociales, aunque 
puede considerarse aún como una propuesta insipiente, tiene experiencias significativas que han tenido su resonancia en políticas educativas, en la construcción curricular y en prácticas pedagógicas, concibiendo en trabajo docente bajo concepciones opuestas a las de corte tradicional. Estas organizaciones se han congregado en lo que hoy se conoce como el Movimiento Pedagógico Revolucionario.

\section{El Movimiento Pedagógico Revolucionario}

En Venezuela, las conquistas por una educación inclusiva tienen el sello de la participación social. El Movimiento Pedagógico Revolucionario (en adelante MPR) tiene su origen en importantes y complejos procesos de construcción educativa, entre ellos pueden mencionarse:

a) Los debates para la comprensión de la realidad educativa venezolana y latinoamericana imperantes hasta la entrada del siglo XXI.

b) Las propuestas de experiencias escolares y de educación popular bajo paradigmas pedagógicos críticos y emancipadores (Simón Rodríguez, Paulo Freire, la corriente marxista, Gramsci, Fals Borda, entre otros).

c) Los procesos de definición, en el contexto de surgimiento y desarrollo de la Revolución Bolivariana, de una educación emancipadora que supere la división social del trabajo, obture la separación de teoría y práctica y promueva la acción social transformadora.

Este movimiento está integrado por educadores, colectivos organizados y sujetos sociales, de toda la geografía nacional, con pluralidad de corrientes de pensamiento pero cuyo tronco común es la ruptura de los dispositivos colonizadores subyacentes en la escuela y en la acción educativa, además de dar impulso a la construcción de la democracia participativa y protagónica (Gutiérrez Sojo, Mirna, 2016).

El MPR ha tenido un gran impacto en la formulación de políticas educativas, en la transformación del sistema doctrinario y la transformación curricular bajo una acción contestataria y contra hegemónica fundamentada en la politización de la pedagogía y la pedagogización de la política. La propuesta político - pedagógica del MPR busca en esencia que las escuelas se conviertan en espacios del quehacer comunitario, una 
escuela que genere conocimiento liberador que permita potenciar la producción para el desarrollo endógeno local.

Uno de los mayores alientos en la transformación de las políticas educativas aportados por el MPR y que a su vez le dan definición y fundamento es el Encuentro de Río Chico. Este encuentro que se realiza en el año 2009, en la ciudad de Río Chico del estado Miranda, congrega a colectivos y sujetos sociales de todo el país para la formulación de propuestas que den paso a la aprobación de una nueva Ley Orgánica de Educación, dichas propuestas se recogen en un documento denominado Declaración de Río Chico. Entre las propuestas más trascendentes de esta declaración se mencionan:

d) La recuperación del Estado Docente, caracterizado por

el tipo de democracia que reivindica, por la naturaleza de la participación que promueve (tal es el caso de los postulados del Art. 62 de la Constitución de la República Bolivariana de Venezuela (CRBV), donde se integran las tareas de formulación, planificación, ejecución y evaluación de políticas públicas), es decir, estamos en un período de transición donde se están creando las bases del ESTADO COMUNAL Y DE CONSEJOS con formas de democracia directa o democracia real: consejos de trabajadores, comunales, de mujeres y hombres, de los y las estudiantes, campesinos y campesinas, etc. En el contexto de la comuna, como nueva geometría del poder, la escuela se constituye en un espacio de construcción del poder popular, democratizando el saber, desarrollando la soberanía cognitiva de los ciudadanos y ciudadanas en el caserío, urbanización o barrio (p. 2).

e) Su incidencia en la gestación de una nueva cultura y organización escolar que diera paso a la constitución de los Consejos Educativos impulsó que en la Ley Orgánica de Educación aprobada, en 2009, se planteara un tipo de gestión educativa fundamentada en el principio de corresponsabilidad social. La propuesta consejista llega a materializarse en la formulación de la resolución ministerial 058, aprobada en 2012, la cual plantea como estructura de gobierno escolar al Consejo Educativo integrado por estudiantes, docentes, trabajadores obreros y administrativos, equipos directivos, consejos comunales y otras organizaciones comunitarias, además de sujetos sociales. 
f) La construcción curricular, entendida como un proceso en permanente desarrollo y con anclaje social debe contemplar la educación para el trabajo pero sin reproducir las condiciones del trabajo bajo concepciones capitalistas. De lo que se trata es de dar una batalla en el marco de la transformación curricular contra la enajenación del trabajo. Ello involucra: "superar la separación del trabajo manual del intelectual, combatir la contradicción entre la teoría y la práctica, lo que en términos curriculares significam enfrentar la fragmentación y atomización del saber expresadas en las disciplinas [...]” (p. 4).

g) Un enfoque educativo que postula la investigación - acción como aspecto fundamental en la formación de los docentes. Se reivindica al maestro - pueblo, como aporte significativo en la construcción de una pedagogía alternativa. Así mismo se propone validar los saberes populares y legitimar los espacios educativos no convencionales.

h) La acción educativa debe ser una acción situada con pertinencia socio- histórica, ello supone el alcance de la soberanía productiva y tecnológica. De allí que se promueva, desde la escuela - comunidad la valoración de los saberes ancestrales, tradicionales, artesanales y las tecnologías intermedias y de punta para la producción que garantice una alimentación sana, segura, sabrosa y soberana (p. 5).

i) Una nueva racionalidad comunicativa a través del fortalecimiento del sistema de comunicación pública, de emisoras y televisoras comunitarias y la constitución de redes de comunicadores populares para el combate de las distorsiones comunicativas y manipulaciones propagandísticas (Ídem).

j) Se propone la educación laica de manera que garantice la libertad de culto y apoya el macro - ecumenismo.

Con la convicción de la necesaria integración y unidad de los pueblos latinoamericanos en sus luchas por un modelo pedagógico emancipador, el 
MPR ha impulsado la Expedición Pedagógica. Este evento reúne a docentes con una militancia comprometida con la pedagogía de la emancipación de Venezuela, Colombia, México, Argentina y Uruguay. La expedición pedagógica representa un espacio en el que los maestros, educadores populares y organizaciones de diferente idiosincrasia, debaten y comparten experiencias que suponen auténticas manifestaciones de resistencia (en términos de Giroux) frente a las prácticas reproductoras de la escuela de tradición conservadora.

Los procesos de transformación de la educación, no pueden pasar de meras reformas si no forman parte integrante de otro proceso de rupturas con el viejo orden económico y sociocultural que involucre al Estado, a la sociedad y al territorio. En este sentido, cobra mayor significación la concepción de la escuela como centro del quehacer comunitario y por ende, otro modelo pedagógico con el que se piense la formación para el trabajo productivo liberador y la participación de las personas en los asuntos públicos, todo ello supone un rico aporte de la escuela en la formación para el desarrollo productivo endógeno local.

Esta trilogía Estado - Sociedad - Territorio, requiere de la inserción de la escuela en el desarrollo productivo local, ahora bien, este encadenamiento será posible por la creación de un sistema de economía comunal a través de la organización de empresas de producción social y de núcleos de desarrollo endógeno a los que la escuela debiera necesariamente vincularse, a través de la educación en y para el trabajo productivo.

\section{Tensiones y contradicciones de la educación venezolana}

Pero la política educativa materializada en la Educación Bolivariana se ha topado con fuertes resistencias de orden político - ideológico. En Venezuela han coexistido dos formas de concebir la educación desde la ascensión al poder de la Revolución Bolivariana. Las tensiones creadas por las fuerzas políticas antagónicas y en franca oposición que perviven a pesar de que la corriente transformadora bolivariana haya prevalecido en el gobierno durante los últimos 16 años han ralentizado su evolución. El proyecto educativo se ha topado, desde sus inicios, con fuertes resistencias de fuerzas políticas, sindicales, académicas, religiosas, con posicionamientos ideológicos neoliberales que luchan por mantener su ya deslustrada hegemonía. Estas tensiones políticas en el sector educativo no son ajenas 
al resto de los conflictos políticos que se han generado en el país desde la propuesta de gobierno de Hugo Chávez ${ }^{3}$. Por otro lado, la burocracia legalista ha producido un retardo en la elaboración del diseño curricular, de leyes y reglamentos que permitan realizar transformaciones en la formación inicial y permanente del profesorado y en la forma de estructuración de la Educación Secundaria. Ejemplo de ello es el caso de la dilación que produjo, para el avance de la nueva propuesta educativa la elaboración de una ley orgánica de educación. Desde 1999 que se elabora el PEN, no es sino hasta el año 2009 que la Asamblea Nacional deroga la vieja ley de 1980 y promulga una nueva.

Algo similar ocurre con las transformaciones curriculares, es cierto que desde el año 2000 se inicia una transformación de la Educación Básica cuyo objetivo principal es hacer frente a la exclusión, garantizando la gratuidad de la educación y proporcionando una serie de programas de atención integral a la infancia y a la familia para hacer posible el acceso real al derecho a la educación. No obstante, el diseño curricular para el nivel de Educación Inicial no se aprueba sino hasta el año 2005. En el caso de la Educación Primaria, se formula un diseño curricular pero nunca fue aprobado, de manera que prevalece el diseño curricular de 1996. En el caso de la Educación Secundaria, la reforma de 1996 nunca elaboró los programas para este nivel, según datos aportados por el estudio documental de Y. Ramírez (2010), los programas de Educación Media fueron revisados en el año 1991, pero su plataforma data del año 1973. Es durante el desarrollo

3 A partir de las primeras acciones de gobierno del presidente Hugo R. Chávez Frías, que mostraron una clara ruptura con los grupos económicos representantes del poder hegemónico durante todo el siglo XX, se evidenció una fuerte división opositora a la propuesta de gobierno chavista. Las primeras reacciones se muestran con la aprobación de la polémica Ley de Tierras, que pretendía eliminar los latifundios, estimular la producción agrícola y pecuaria de sectores campesinos sin tierras, otra de las leyes que generan una fuerte reacción son las leyes habilitantes solicitadas por el presidente para intervenir de manera radical en la reversión de los grandes problemas con los que se inició el siglo XXI: alta desnutrición, pobreza y pobreza crítica, desempleo, deserción escolar, mendicidad, niños, niñas y adolescentes en situación de calle, analfabetismo, mortalidad infantil, entre otros. El nivel de polarización alcanzó su mayor encono en el año 2002 con el golpe de Estado propiciado por un sector de los militares, aliados con la burguesía comercial y petrolera. El otro evento se suscitó en el año 2003 con el mayor sabotaje a la industria petrolera que se haya podido registrar en la historia venezolana. 
del año 2016 que se ha concretado una propuesta curricular que, aunque está aún por salir al debate público, ya tiene fuertes detractores en los grupos de oposición al gobierno bolivariano.

La propuesta de gobierno del presidente Hugo R. Chávez Frías, vertida en la Revolución Bolivariana, va a caracterizarse por el zigzagueante movimiento entre la confluencia de fuerzas hegemónicas nacionales e internacionales, las cuales han generado una enérgica tensión política manifiesta en una férrea oposición de los antiguos sectores de la extinta burguesía petrolera y la cámara de empresarios privados (Fedecámaras), frente al vigoroso apoyo popular que se mantuvo durante sus 14 años de gestión. En cifras puede constatarse este respaldo popular que alcanza el $71 \%$, en el año 2007, y se mantiene siete años después, en el ocaso de su vida, en el $68 \%$.

En la apertura de su nuevo mandato presidencial en el año 2012, Hugo R. Chávez Frías presenta en el primer Consejo de Ministros una serie acciones que se derivan del nuevo plan de la nación Plan de la Patria, las cuales suponen un nuevo ciclo dirigido a profundizar las transformaciones que necesita el país bajo el lema de "eficiencia o nada». Con ello pretende corregir los reveses de la gestión y lanzar una serie de decisiones que bautiza con el nombre de "golpe de timón»". El nuevo plan de la nación contiene 5 objetivos históricos que persiguen la consolidación del Socialismo del Siglo XXI, fortalecer la independencia y garantizar la irreversibilidad de la soberanía nacional, preservar la soberanía de los recursos naturales y en especial los recursos petroleros, lograr la soberanía alimentaria desencadenando el potencial agro - productivo y la consolidación del poder defensivo nacional a través de la unión cívico militar. (Plan de la Patria, 2012). Este plan de gobierno se propone en sus objetivos estratégicos generales la construcción de una sociedad igualitaria y justa, para ello se formulan los objetivos estratégicos que tienen alcances

4 Con este término el entonces mandatario nacional Hugo R. Chávez Frías bautiza el giro que debía suponer la nueva acción de gobierno, de manera que se impulsaran las políticas de transformación expuestas en el plan de gobierno con el conquistó la mayoría electoral en las elecciones de 2012. La primera de las acciones urgentes debía estar orientada a la eficiencia en la gestión pública, la segunda hacia la profundización del poder comunal, a través de la organización de las comunas y la tercera hacia el combate de la corrupción en todos los órdenes y ámbitos de la administración de lo público. 
en diversos ámbitos de la vida social, en el caso de la educación se propone: "Continuar garantizando el derecho a la educación con calidad y pertinencia, a través del mejoramiento de las condiciones de ingreso, prosecución y egreso del sistema educativo" (Ibídem, p. 58).

Este gran objetivo en el área educativa se desglosa en otros específicos enfocados a:

- Desarrollar el Currículo Nacional Bolivariano.

- La extensión de la cobertura de la matrícula escolar por nivel de educación. En este sentido, se realiza un balance de la cobertura desde el año 1999 hasta el 2012 y la proyección hasta el año 2019. Se busca que para el 2019 se eleve la cobertura en educación maternalel del 13\% hasta el 40\%; elevar al 100\% de la cobertura la educación preescolar; al 100\% la educación primaria; de igual forma se espera que el $100 \%$ de la población alcance un nivel promedio de instrucción no menor a la media general o media técnica

- Ampliación de la infraestructura y dotación escolar y deportiva.

- Continuar incorporando a las TIC en el proceso educativo.

- Profundizar la acción educativa comunicacional y de protección al ambiente.

- Desarrollar la educación intercultural bilingüe, promoviendo el rescate y preservación de las lenguas indígenas.

- Desarrollar programas y proyectos de formación - investigación que den respuesta a las necesidades y potencialidades productivas para el proyecto nacional

- Desarrollar programas en educación en los que se incorporen contenidos enfocados a los conocimientos ancestrales y populares.

\section{La propuesta de desarrollo curricular}

A partir del año 2012 se propone el nuevo diseño curricular fundamentado desde el punto de vista legal en el plan de la nación Plan de la Patria (2012 - 2019) el cual adquiere el rango de ley a partir del año 2013, en la CRBV (1999), en la Ley Orgánica de Educación (2009) y el la Ley Orgánica para la Protección de Niños Niñas y Adolescentes (2007). 
Las líneas generales estratégicas del diseño curricular están orientadas al desarrollo de un nuevo modelo pedagógico que desplace la concepción neoliberal de los anteriores y se constituya en el impulso necesario para las transformaciones en el orden social, económico, político y cultural de la nueva república igualitaria, de justicia libre y soberana.

Se propone la correspondencia entre la teoría y la práctica, entre el conocimiento disciplinar y su manifestación en los fenómenos naturales,

\section{Gráfico 2 - Bases Doctrinarias Del Cnb}

ORDENAMIENTO JURÍDICO QUE ATIENDE EL CURRICULO NACIONAL BOLIVARIANO

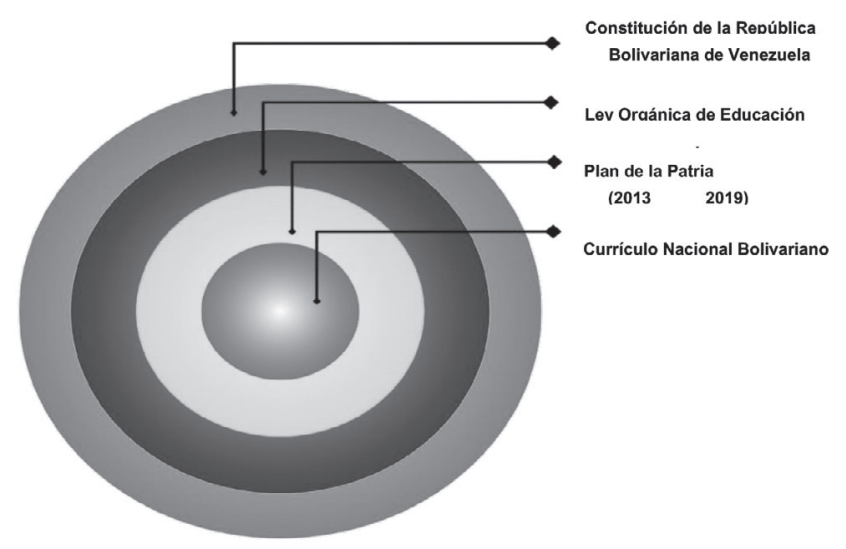

Fuente: Ministerio Del Poder Popular Para La Educación, 2011.

sociales y en los objetos y realidades que nos rodean, así como también reducir la brecha que separa el trabajo intelectual del trabajo manual, nociones que son propias de un modelo educativo capitalista que favorece la división social del trabajo. Esta concepción requiere de una transformación en la idea fragmentada y atomizada de las disciplinas, en el distanciamiento del docente y el alumno y de la escuela y la comunidad. En cambio, se favorece la concepción interdisciplinar y transdisciplinar que permite la contextualización del conocimiento y la ruptura con la organización piramidal de la escuela. Así mismo se postula el modelo didáctico centrado en los procesos que tienen que ver con la creatividad, investigación y la innovación, además de comprender la formación como parte de un continuo humano. 
La educación en y para el trabajo se plantea desde la perspectiva del diálogo de saberes con la finalidad de recuperar los saberes ancestrales, tradicionales, artesanales para combatir el neocolonialismo y la dependencia cognitiva, tecnológica y científica. La acción educativa emancipadora privilegia la educación intercultural cuya finalidad es la de preservar la dignidad y el respeto por las culturas que componen la idiosincrasia venezolana.

\section{Consulta Nacional por la Calidad Educativa}

Durante el año 2014 como parte de la política educativa se realizó la Consulta Nacional por la Calidad Educativa, la cual significó un mecanismo para evaluar los avances alcanzados y ubicar los escollos pendientes por resolver a través de la implementación de políticas públicas. Se consultaron 20.748 instituciones educativas, tanto públicas como privadas y se discutieron 11 ejes temáticos a través de diversas técnicas de recopilación de información. Así mismo se consultaron diversos sectores de la población tales como docentes, estudiantes, familias, consejos educativos, organizaciones comunitarias, cultores populares, deportistas, organizaciones ambientalistas, campesinos, obreros, grupos confesionales religiosos, movimientos de diversidad sexual, colectivos de mujeres, de jóvenes, instituciones de Estado, pescadores, pueblos indígenas, afro-venezolanos, entre otros, en un intento por abarcar toda la diversidad de la sociedad venezolana.

Dentro de los resultados de la Consulta se pueden destacar aquellos relacionados con la inclusión:

De las 8.194.091 personas que integran la matrícula de Educación Básica, la mayoría es responsable directa del sector oficial: $81,39 \%$ en Inicial, $82,05 \%$ en primaria, 78,6 en media [...] Los estudios realizados en el marco de la Consulta apuntan que parte de los resultados de estas políticas de inclusión educativa se observan en la reducción sostenida del abandono escolar (MPPE, 2014).

El abandono escolar en el nivel de Educación Media, para el año 2001 - 2002 era de 17,17\% y para el año 2011-2012 descendió al 7,82\%. Este mismo dato se recoge en el nivel de Educación Primaria; para el año 2001-2002 el abandono escolar era de 3,79\% mientras que para el año 2011-2012 desciende al 0,15\%. 
La repitencia escolar, para el año 2001-2002 en el nivel de Educación Media es de 9,26\%, mientras que para el año 2011-2012 baja al 4,11\%. En el nivel de Educación Primaria, la repitencia escolar para el año 20012002 es de 7,65\% y para el año 2011-2012 desciende al 3,26\%.

Este estudio reveló que aún hay niños que están fuera del sistema escolar:

Tabela 1 - Estudiantes fuera del sistema escolar. Año 2012-2013

\begin{tabular}{|c|c|c|}
\hline NIÑOS, NIÑAS Y AD & $\begin{array}{l}\text { ENTES FUERA DEL SISTEN } \\
\text { POR GRUPOS DE EDAD. } \\
\text { AÑO ESCOLAR 2012-2013 }\end{array}$ & E EDUCACIÓN BÁSICA \\
\hline Grupos Etarios & Dentro del Subsistema & Fuera del Subsistema \\
\hline De 3 a 5 años & 1.276 .067 & 318.472 \\
\hline De 6 a 11 años & 3.129 .173 & 91.855 \\
\hline De 12 a 16 años & 2.068 .530 & 365.324 \\
\hline
\end{tabular}

Fuente: Elaboración propia con datos emanados de la Consulta por la Calidad Educativa (2014).

Los temas discutidos en la consulta mostraron resultados interesantes en áreas que se constituyen como aspectos nucleares de la calidad educativa, tales como el necesario cambio del paradigma tradicional de la formación inicial y permanente de los docentes, en este sentido se constató que del total de las instituciones formadoras en la carrera de Educación, el $54,54 \%$ son universidades y el $45,46 \%$ son institutos y colegios universitarios. En este dato se observa que de las 66 instituciones que ofrecen la carrera de Educación, 36 de ellas son privadas y 30 son públicas. $\mathrm{Al}$ consultar a dichas instituciones sobre la calidad de la formación de los docentes se constató:

Especialmente docentes y universidades reconocen debilidades en la formación inicial de docentes que se expresan en el insuficiente manejo de los contenidos, en métodos de enseńanza poco innovadores, sin uso de recursos didácticos que estimulen al proceso de aprendizaje como un momento creativo y divertido. La formación inicial da poca importancia a las pedagogías del amor y el ejemplo (Ibídem).

Las debilidades en la formación de los docentes fue un dato recurrente en la consulta realizada en las diferentes subregiones del país, tanto en las 
instituciones que prestan el servicio de educación universitaria de manera pública como de prestación privada. Así mismo se criticó la desarticulación existente entre el currículo de formación docente y la oferta de menciones con las necesidades y dinámicas de desarrollo del sistema educativo.

Los estudios revelaron la inexistencia de articulación entre los programas de formación inicial en docencia y el perfil de los estudiantes del subsistema de educación básica y las disposiciones de la LOE. Por lo que se recomienda se vinculen de manera permanente (Ibídem).

El recorrido mostrado hasta hora revela el esfuerzo por un posicionamiento del Estado Docente responsable de dictaminar las políticas públicas que garanticen la inclusión y la calidad educativa de todos los sectores sociales. A su vez, se revelan las dificultades en el avance hacia las transformaciones para superar las prácticas hegemónicas neoliberales, instauradas en el modelo educativo y apoyadas, por el sistema económico y la industria comunicacional y cultural capitalista.

\section{La situación actual. Circunstancias y contingencias}

En los actuales momentos, en los que las democracias legítimamente constituidas, están en franca amenaza por la avanzada, en su expresión más fascista, de las oligarquías asesoradas y financiadas por el departamento de Estado de EEUU, en una empresa perversa de recuperación del poder, la unidad e integración de América Latina cobra una importancia transcendental. En este contexto decisivo, se hace apremiante la acción educativa asumida como militancia, con un posicionamiento político e ideológico en favor del derecho de los pueblos nuestroamericanos a la autodeterminación y a la soberanía.

Los años adversos de configuración de sistemas educativos excluyentes, sin orientación hacia el desarrollo de conocimientos para alcanzar la soberanía productiva en los sectores alimentario, farmacológico, industrial, cultural, han servido de caldo de cultivo para que las fuerzas imperiales, utilizando como instrumento al mercado, ponga en vilo los logros alcanzados por los pueblos en los tres primeros lustros del siglo XXI.

En el caso venezolano, la cultura rentista del petróleo ha sido el talón de Aquiles de la Revolución Bolivariana. Desde el año 2000, en Venezuela, 
se han ensayado innumerables intentos de sabotajes y atentados a la democracia participativa y protagónica impulsada por la Revolución Bolivariana, dos de ellos consumados, uno el 11 de abril del año 2002 con el golpe de Estado al entonces presidente Chávez y el sabotaje petrolero en el año 2003; pero ambos revertidos por la acción organizada del pueblo. Durante los años siguientes se han editado un sinnúmero de golpes suaves en el marco de lo que desde el documento de William Link se ha denominado «la guerra de cuarta generación $(4 \mathrm{GW})$ » en la que el campo de batalla se encubre en la cotidianidad de la vida social.

El agotamiento del modelo rentístico petrolero, aunado al débil desarrollo del sector productivo de rubros agroalimentarios, del sector salud, tecnológico - industrial, han servido de estribo al fuerte bloqueo económico impuesto por las trasnacionales farmacéuticas, de alimentos, de insumos industriales. A esta situación se suman dos fuertes sequías, la de 2010 y la de 2015-2016 que han provocado la erosión de los suelos cultivables. En esta empresa guerrerista para aniquilar la Revolución han colaborado las campañas mediáticas de medios privados internacionales y nacionales, además de organismos internacionales como la OEA y MERCOSUR cuya colaboración no puede tildarse sino de vergonzosa por el tipo de acciones desplegadas que superan los límites de la legalidad internacional.

Los avances por la integración real de los países de América Latina, en un intento de construir un mundo multipolar, materializados en el ALBA - TC, la UNASUR, la CELAC, el CARICOM, lograron detener la avanzada neoliberal, como el acuerdo del ALCA y promover acuerdos comerciales estratégicos bajo principios de cooperación solidaria y respeto por la autodeterminación de los pueblos. Pero era de esperarse la reacción de los grandes lobbies de poder, la estrategia de vuelta al pasado que se ha desplegado en América del Sur con la finalidad de jalonar el retroceso de gobiernos progresistas y de izquierda cierne su amenaza cada vez más violenta. El sociólogo Carlos Lanz ha denunciado en múltiples ocasiones la implementación de la estrategia "Rollback"

que posee como vértice la descomposición o degradación de las fuerzas revolucionarias, a través de una serie de políticas económico-sociales, ético-culturales, asumidas metodológicamente como 'campañas' y 'operaciones encubiertas' (C. LANZ, 2016, p. 23. <https://www.aporrea. org/actualidad/a239518.html>). 
En Venezuela, la guerra de cuarta generación se ha caracterizado por el ataque a la economía a través del desabastecimiento programado, el contrabando, la especulación de precios, la inflación inducida, el ataque a la moneda (dolarización), las operaciones psicológicas que buscan quebrar la emocionalidad, despojando a la población de aquellos elementos materiales y simbólicos con los que construye su cotidianidad. En esta conjura, la participación de los medios de comunicación e información privados nacionales e internacionales han tenido un protagonismo de primer orden. Las últimas amenazas provenientes de la operación Venezuela Freedom - 2 formulada por el Comando Sur de los EEUU tienen su marco de encuadre en la "crisis humanitária", excusa con la que el imperio amenaza permanentemente con una intervención.

En estas circunstancias, la contingencia debe orientarse a pensar en el urgente impulso de una nueva sociedad, un nuevo orden, un nuevo sujeto. José Martí planteaba que: "[...] tendría que declararse por segunda vez la independencia de la América Latina, esta vez para salvarla de los Estados Unidos". De allí que las políticas educativas y la acción de los docentes, si no son para vencer definitivamente la influencia de la pedagogía bancaria como la denominó Paulo Freire en la construcción de ciudadanos pasivos y promover la pedagogía crítica, para la emancipación, seguirán generando escuelas sin sentido y sujetos sin compromiso histórico con su tierra y su cultura.

El tipo de democracia construido en el nuevo siglo en los países de América Latina ha dado un giro hacia el robustecimiento del Estado y la institucionalidad, las balanzas de poder se inclinan cada vez más hacia la participación popular y hacia la visibilidad de los excluidos, en el caso de Venezuela, el modelo democrático es participativo y protagónico, lo cual abre un compás necesario a la articulación de las organizaciones populares y movimientos sociales con las políticas públicas. En este sentido, la historia reciente ha ido develando cómo este modelo democrático es incompatible con el modelo económico que desarrollan las trasnacionales y con los acuerdos comerciales neoliberales. De allí que las políticas educativas en nuestro continente deban orientarse a fortalecer el desarrollo sustentable, ese que promueve el desarrollo desde adentro y que considera la dimensión ambiental y sociocultural como componentes indispensables para la preservación de la vida.

La educación, en términos bolivarianos debe ser un instrumento de emancipación y la escuela, el campo de resistencia (Giroux) y de lucha para alcanzarla. Entendiendo, además la escuela como aquella que trasciende los límites físicos de las aulas de clase, los pasillos y las verjas, 
convirtiéndose en espacios del quehacer comunitario al tiempo que la comunidad se convierta en espacios del quehacer educativo. Para que este fin se materialice es necesario que se fortalezcan los mecanismos participativos en la vida pública de los educadores en una sinergia perfecta con las organizaciones comunitarias.

Walter Benjamín comparó al capitalismo con un tren que viaja inexorable hacia el abismo y a la revolución socialista como el freno. Hoy más que nunca se corrobora el abismo hacia donde conduce la influencia imperial norteamericana sobre los pueblos, no hay un ejemplo en el mundo de pueblo próspero y en paz por el que haya pasado la intervención estadounidense. En América Latina, la educación debe formar parte de la reconducción de ese tren y echar a andar un nuevo trayecto histórico hacia la construcción de un nuevo sujeto para un nuevo orden social.

Uno de los más urgentes retos en Nuestramérica, lo fue hace dos siglos, lo es ahora, es consolidar los mecanismos de integración para materializar la construcción de un bloque cultural e histórico capaz de frenar el tren del capitalismo. Ya lo dijo el Libertador de América Simón Bolívar en su mensaje al Congreso de Colombia "La unidad de nuestros pueblos no es simple quimera de los hombres, sino inexorable decreto del destino".

\section{Referencias}

ALTHUSSER, Louis. Ideología y aparatos ideológicos del Estado. 1988, Disponible en: <https://www.marxists.org/espanol/althusser/1970/iv.htm>.

ARIZA, Gustavo Rosales. Geopolítica y geoestrategia. Liderazgo y poder. Ensayos. Universidad Militar Nueva Granada. Bogotá. D.C. Colombia, 2005.

BIGOTT, Luis Antonio. Redes socioculturales y participación comunitaria. Ministerio del Poder Popular para la Educación. Caracas - Venezuela, 2013.

Boletín de indicadores educativos. Ańos escolares 2003/04 al 2013/14. Instituto Nacional de Estadística. Venezuela, 2014.

BONILLA, Luis. Apagón pedagógico global. Las reformas educativas en clave de resistencia. Revista Viento Sur. no 47, p. 92-101, 2016. Disponible en: <http:// vientosur.info/spip.php?article11627>.

BORÓN, Atilio. América Latina en la geopolítica del imperialismo. Ministerio del Poder Popular para la Cultura. Venezuela, 2012. 
BOUDELOT, C; ESTABLET, R. La escuela capitalista en Francia. Editorial Siglo XXI. Madrid - España, 1987.

BOURDIEU, Pierre; PASSERON Jean-Claude. La reproducción: Elementos para una teoría del sistema de enseñanza. Barcelona - Espańa, 1996.

CARVAJAL, R. Samuel; VILLASMIL, S. Paulina. Apuntes para repensar las políticas públicas dirigidas a la formación docente en Venezuela. En: Políticas para la formación de docentes. Proyectos y experiencias en el contexto Latinoamericano. Compiladores: Meghini Raúl Y María Rosa Misuraca. Jorge Baudino Ediciones, 2014.

CASTRO Gómez, Santiago; GROSFOGUEL, Ramón. El giro decolonial. Reflexiones para una diversidad epistémica más allá del capitalismo global. Bogotá: Siglo del Hombre Editores, 2007.

Constitución de la República Bolivariana de Venezuela. Asamblea Nacional Bolivariana. Venezuela, 1999.

CONTRERAS, Rolando Pinto. Pedagogía crítica para una educación pública y transformadora en América Latina. Vol. II. Perú: Editorial Derrama Magisterial, 2014.

Declaración de Río Chico. Movimiento Pedagógico Revolucionario. Venezuela, 2009.

FIGUEROA, L. B. Prieto La Escuela Nueva en Venezuela. Caracas: Fundacción Editorial El Perro y la Rana, 2007.

FREIRE, P. Papel da educação na humanização. Revista Da Faeeba: Salvador, no 7, jan./jun., 1997.

GIROUX, Henry. Teorías de la reproducción y la resistencia en la nueva sociología de la educación: un análisis crítico. Disponible en: <http://www. pedagogica.edu.co>.

GONZÁLEZ, Alfonso Rumazo. Ideario de Simón Rodríguez. Ministerio del Poder Popular para la Educación. Caracas - Venezuela, 2008.

GLOVER, Ovidio Andrés Charles Van. Educación Básica, Revolución Bolivariana y contexto del MERCOSUR: Debates y perspectivas. En: Trabalho e a formação do professor de Educação Básica no MERCOSUL/CONE SUL. Florianópolis - Brasil, 2012. 
KOHAN, Walter O. El maestro inventor Simón Rodríguez. Miño y Dávila, srl. Argentina, 2013.

LANZ RODRÍGUEZ, Carlos. Memória histórica e innovación pedagógica. Ministerio del Poder Popular para la Educación. Venezuela, 1999.

LÉON, Magdalena T. El 'bien vivir': objetivo y camino para otro modelo. In: LÉON, Irene (Coord.). Sumak kawsay/Bien vivir y cambios civilizatorios. Quito: FEDAEPS, 2010. p. 105-123.

Ley Plan de la Patria. Asamblea Nacional Bolivariana. Venezuela, 2013.

MED. La Educación Bolivariana. Políticas, programas y acciones.

“Cumpliendo las metas del milenio". Caracas, 2004.

MPPE. Obtenido de Consulta Nacional por la Calidad de la Educación.

Diciembre de 2014. Disponible en: <http://www.consultacalidadeducativa. me.gob.ve/>.

MÉSZÁROS, István. El desafío y la carga del tiempo histórico. El socialismo del siglo XXI. Venezuela: Vadell Hermanos Editores C. A, 2008.

Ministerio de Educación, M. Proyecto Educativo Nacional. Versión preliminar de la sistematización de las propuestas regionales. Caracas: Escuela Social Rodriguena Latinoamericana y del Caribe, Oct. de 1999. Disponible en: <http:// www.saber.ula.ve/>.

QUINTERO, Rodolfo. La cultura del petróleo. Biblioteca del pensamiento económico. BCV. Caracas - Venezuela, 2011.

RODRÍGUEZ, Carlos Lanz. Ejecución de la Operación Venezuela Freedom: Estrategia rollback y los planes del Comando Sur contra Venezuela, 2016. Disponible en: <http://www.aporrea.org/actualidad/a230125.html>.

. Memoria histórica e innovación pedagógica. Ministerio del Poder Popular para la Educación. Venezuela, 2009.

SOJO Mirna Elizabeth Gutierréz. Movimientos pedagógicos y políticas educativas. Estudio comparado. Editorial Académica Española, 2016. Disponible en: <http://mirnasojo.webnode.es/presentacion/>

TRUJILLO, Magdalena León. El 'buen vivir': objetivo y camino para otro modelo. In: LEON, Irene (Coord.). Sumak Kawsay/Bien vivir y cambios civilizatorios. Quito: FEDAEPS, 2010. p. 105-123. 


\title{
JOIAS DO ASÉ - UM ESTUDO NA PERSPECTIVA DA ETNOMATEMÁTICA
}

\author{
José Carlos Dias Ferreira ${ }^{1}$ \\ Rachel de Oliveira ${ }^{2}$ \\ Marcos Rogério Neves ${ }^{3}$
}

\section{Introdução}

A formação de professores da educação básica tem sido alvo de discussóes nas questóes concernentes ao sistema educativo, principalmente, após a implementação da Lei de Diretrizes e Bases da Educação Nacional - LDBEN, no 9.394/1996 que atribui ao ensino superior a formaçáo desses profissionais, como espaço adequado para a resolução de inúmeros problemas educacionais.

Nesse cenário, encontram-se as universidades com o grande desafio de formar professores com conhecimentos acadêmicos, compromisso político com vistas nas transformaçôes educacionais e sociais, bem como a adequação às novas tecnologias e, sobretudo, a aplicabilidade dos conhecimentos adquiridos no processo de formaçáo dos educandos em meio às provocaçóes da sociedade contemporânea constituída por distintos padrôes, métodos e práticas educativas. Visando dirimir essas dificuldades, fora instituído o Plano Nacional de Formação de Professores da Educação Básica - PARFOR, cujo objetivo consiste em colaborar com a formação inicial dos professores em exercício que não possuem a graduação específica para sua atuação (BRASIL, 2009a).

No entanto, essa formação apresenta questóes subjetivas que carecem de análise e discussão, uma vez que a formação de professores permite ao docente adequação e atualização de sua prática, cooperando assim para a

\footnotetext{
IFBaiano, Uruçuca, Bahia, Brasil. E-mail: <prof.jcdias@gmail.com>.

2 Departamento de Ciências da Educação. UESC. Ilhéus, Bahia, Brasil.

E-mail: <rakkadeoliveira@gmail.com>.

3 Departamento de Ciências Exatas. UESC. Ilhéus, Bahia, Brasil.

E-mail: <marcos_neves@uesc.br>.
} 
superação dos problemas não apenas educacionais, mas também sociais e a melhoria da qualidade na educação.

Escolheu-se como objeto de estudo desta pesquisa a formação de professor pela necessidade de aprofundar a reflexão sobre o impacto desse processo em andamento no Brasil, oferecida aos professores da Educação Básica, em nível superior nas diversas instituições públicas do Brasil. Dessa forma, foram definidas algumas especificidades do professor em formação na educação superior, fundamentadas nas políticas públicas instituídas para a educaçáo brasileira, sobretudo o PARFOR, com a finalidade de aprofundar os conhecimentos mesclados pelos entraves e conquistas desse Plano em vigor no cenário educacional.

Diante das demandas impostas ao sistema educacional, novas exigências surgem na perspectiva de integrar os professores aos mais distintos paradigmas propulsores do desenvolvimento que são imbricados ora pelas propostas tecnológicas, ora pela apreensão e produção do conhecimento. Ao discutirem sobre a formação do professor, Libâneo e Pimenta (1999, p. 22) já diziam que "não é qualquer um que pode ser professor", visto que o professor necessita ser formado. Nesse contexto, encontram-se os protagonistas desse embate, os profissionais da educação que tentam, na medida do possível, compreender as ocorrências e os desfechos para tantas mazelas sociais e através de suas açôes reforçam suas práticas e contribuem para o desenvolvimento das habilidades e competências de seus educandos, no tocante ao processo de ensino e aprendizagem.

No contexto atual, faz-se necessário assimilar o conhecimento à complexidade do inacabado, visto que o profissional da docência deve vislumbrar o conhecimento como um processo contínuo que se constrói e reconstrói a partir das aspiraçóes presentes em seu exercício (FREIRE, 2006). Portanto, a educação é um compromisso fundamentado em reflexôes e relaçóes pessoais e interpessoais permeadas pelos valores morais, éticos e sociais que envolvem toda a sociedade, sendo a escola um espaço privilegiado para aprimorar esses valores em meio a discussóes e tomada de decisóes voltadas para a supressão dos problemas sociais, que excedem práticas conservadoras firmadas na transmissão de conhecimentos e na memorização de determinados conteúdos, considerados absolutos.

No bojo das discussóes educacionais, emergem necessidades vitais para o desenvolvimento da educação em todo o país e com isso, a LDBEN no 9.394/1996 estabelece em seu Artigo 62 que "A formação de docentes para atuar na educação básica far-se-á em nível superior, em 
curso de licenciatura, de graduação plena, em universidades e institutos superiores de educação [...]", porém, apesar de aceitar como formação mínima para atuação na educação infantil e nas séries iniciais do ensino fundamental, essa mesma Lei determinou em seu parágrafo $4^{\circ}$, Artigo 87, que "Até o fim da Década da Educação somente serão admitidos professores habilitados em nível superior ou formados por treinamento em serviço". No entanto, o prazo estipulado acabou, em 2006, e essa meta ainda não fora cumprida entre os municípios brasileiros (BRASIL, 1996).

Inúmeras mudanças nortearam a trajetória de formação dos professores no Brasil por meio do aprofundamento das políticas implementadas como a LDBEN no 9.394/1996, as várias Diretrizes, os Pareceres e os diversos Programas, entre outros documentos e apontam os processos formativos dos professores como precedentes para melhorar a qualidade da educação básica. O Governo Federal designou a Política Nacional de Formação de Professores do Magistério da Educação Básica, por meio do Decreto no 6.755, de 29 de janeiro de 2009 e com essa política constituiu o PARFOR, em 30 de junho de 2009, com o objetivo de "organizar, em regime de colaboração entre a União, os Estados, o Distrito Federal e os Municípios, a formação inicial e continuada dos profissionais do Magistério para as redes públicas da Educação Básica”. Portanto, esse Plano oferece cursos de licenciatura na modalidade presencial, conferindo à Primeira Licenciatura o maior número de cursos destinados aos professores que não possuem formação de nível superior e à Segunda Licenciatura uma quantidade menor de cursos para os professores que possuem cursos de licenciatura, mas encontram-se atuando fora de sua área de formação (BRASIL, 2009a).

Contudo, as transformaçôes sociais ocorridas em meio à globalização têm proporcionado ao professor uma formação mais desafiadora e estes desafios estão relacionados com a necessidade de atualização de saberes e a habilitação adequada desses profissionais. Nesse viés, compete às Universidades o grande desafio de acompanhar as transformaçóes sociais e o desenvolvimento tecnológico, principalmente nos cursos de Licenciatura, com vistas na formação de professores mais eficientes e preparados para o mundo social do trabalho, que está cada vez mais exigente. E, diante da necessidade de adequar tempo, espaço e movimentos sociais emergentes, as Instituiçóes de Ensino Superior (IES), por conhecerem as legislaçóes educacionais, disponibilizaram mais cursos com a finalidade de formar professores que respondessem aos desafios sociais contemporâneos e, pela 
demanda da profissão docente, o foco da oferta tornou-se mais acentuado e a procura concentrou-se nos cursos de Pedagogia.

Como aporte teórico recorreu-se aos principais documentos legais que definem as políticas nacionais para a formação de professores no cenário brasileiro e como base metodológica, esta pesquisa caracteriza-se como pesquisa qualitativa, que de acordo com Marconi e Lakatos (2010), tem como premissa, analisar e interpretar aspectos mais profundos que delineiam a complexidade da conduta humana, enfatizados, portanto, pelos processos e pelos significados investigados.

\section{As políticas de formação de professores no cenário brasileiro}

As políticas educacionais brasileiras, especialmente as que contemplam os programas especiais, apresentam problemas desde a sua elaboração, visto que tais propostas anseiam retificar os desajustes observados no cenário educacional. No entanto, estes continuam aquém das garantias para o alcance dos resultados de grande impacto e, não obstante a isso, nota-se que a política de formação de professores no Brasil começou a ocorrer de forma tardia, não sendo, portanto, lugar de destaque nas políticas educacionais ao longo de sua história.

Destarte, o Plano de Desenvolvimento da Educaçáo (PDE) apresentado pelo Ministério da Educação (MEC), em abril de 2007, disponibilizou ao Distrito Federal, aos Estados e Municípios instrumentos para avaliação e implementação de políticas que visem à melhoria da qualidade da educação, principalmente da educação básica do sistema público. A partir de então, as transferências voluntárias e a assistência técnica do MEC aos municípios, estados e Distrito Federal estão vinculadas à adesão ao Plano de Metas, intitulado "Compromisso Todos pela Educaçáo" e à elaboração do Plano de Açóes Articuladas (PAR), que são instrumentos essenciais para a melhoria do Índice de Desenvolvimento da Educação Básica (IDEB).

Nesse cenário de implementaçóes políticas, o MEC desenvolveu alguns Programas, como: o Programa de Formação de Professores em Exercício (PROFORMAÇÃO), em 1997, cuja finalidade é habilitar para o magistério, em nível médio, na modalidade Normal, os professores que exercem atividades docentes tanto nas séries iniciais do ensino fundamental, quanto na Educação de Jovens e Adultos (EJA); a Rede Nacional de 
Formação Continuada de Professores (RENAFOR), em 2004, com o intuito de oportunizar aos professores da educação básica dos sistemas públicos de educação uma formação adequada e, consequentemente, contribuir para a melhoria da formação dos professores e alunos; O Programa de Formação Inicial para os Professores em Exercício na Educação Infantil (PROINFANTIL), em 2004, que teve como referência a metodologia adotada no programa PROFORMAÇÃO, porém, destinado aos professores da educação infantil que não possuem a formação mínima exigida pela legislação brasileira; o Programa Nacional de Incentivo à Formação Continuada de Professores do Ensino Médio (PROIFEM), em 2004, que tem como finalidade permitir que o professor se atualize e aprofunde conhecimentos sobre as questóes pedagógicas relativas ao ensino médio; o Programa de Formação Inicial para Professores dos Ensinos Fundamental e Médio (PROLICENCIATURA), em 2005, que oferece formação inicial a distância para os professores em exercício nos anos/séries finais do ensino fundamental ou ensino médio dos sistemas públicos de ensino; o Programa de Formação Continuada de Professores que atuam nos anos/séries iniciais do Ensino Fundamental (PROLETRAMENTO), em 2006, visando a melhoria do ensino e da aprendizagem dos alunos em leitura, escrita e matemática, entre outros que objetivaram o combate do fracasso escolar (BRASIL, 2005).

De acordo com o MEC, em 2013, todos os 26 (vinte e seis) Estados, o Distrito Federal e os 5.563 (cinco mil, quinhentos e sessenta e três) municípios assinaram o Termo de Adesáo ao Plano de Metas Compromisso Todos pela Educação. Esse Plano foi instituído pelo Decreto 6.094, de 24 de abril de 2007, sendo concebido como um programa estratégico do PDE/MEC capaz de implantar um novo regime de colaboração em virtude da atuaçáo dos entes federados sem comprometer a autonomia dos envolvidos, a decisão política, a ação técnica e o atendimento da demanda educacional; tudo isso com a finalidade de melhorar os indicadores educacionais.

O PAR alvitra políticas voltadas para a Primeira Licenciatura que é destinada aos professores em exercício na educação básica e que não possuem nenhuma graduação, a Segunda Licenciatura para aqueles que atuam na educação básica, mas estão fora da sua área de formação específica e a Formação Pedagógica destinada aos bacharéis que exercem a profissão docente na educação básica.

Assim, a formação de professores com vistas à qualidade social, o domínio e a aplicabilidade das tecnologias inovadoras, bem como o compromisso político, cuja finalidade consiste na transformação da sociedade, são 
considerados um dos grandes desafios na busca por respostas às questóes da sociedade contemporânea, pelos quais enfrentam as Universidades nos cursos de Licenciatura no país.

Por fim, no dia 4 de abril de 2013, foi publicada a Lei no 12.796/2013, que ajusta a LDBEN (9.394/96) à Emenda Constitucional (EC) $\mathrm{n}^{\circ}$ 59/2009, tornando obrigatória a oferta gratuita de educação básica a partir dos 4 anos de idade. A Lei no 12.796/2013 dispóe também sobre a formação do profissional da educação básica pública e dá outras providências (BRASIL, 2013).

Percebe-se, portanto, que a União, os Estados e os Municípios têm a obrigação de promover a formaçáo superior dos professores por meio de bolsas de estudo (BRASIL, 1996). No entanto, essa iniciativa apontada na LDBEN é legitimada nessa nova Lei, mas, na verdade, o Governo Federal já dispunha dessa prática, desde 2010, por meio do Programa Institucional de Bolsa de Iniciação à Docência (PIBID), instituído pelo Decreto no 7.219, de 24 de junho de 2010 .

\section{O Plano Nacional de Formação de Professores da Educaçáo Básica (PARFOR)}

Em 2009, uma das açóes do PDE foi regulamentada por meio do Decreto no 6.755, de 29 de janeiro. Este Decreto consolida a Política Nacional de Formação de Professores da Educação Básica e disciplina a atuação da Coordenação de Aperfeiçoamento de Pessoal de Nível Superior (CAPES), no fomento a programas de formaçáo inicial e continuada e institui em seu Art. $1^{\circ}$

[...] a Política Nacional de Formação de Profissionais do Magistério da Educação Básica, com a finalidade de organizar, em regime de colaboração entre a Uniáo, os Estados, o Distrito Federal e os Municípios, a formaçáo inicial e continuada dos profissionais do magistério para as redes públicas da educação básica (BRASIL, 2009a).

Nesse contexto, o PARFOR surge como resultado do PDE e do PAR em parceria com os Estados acerca dos diagnósticos dos sistemas locais e das demandas oriundas da formaçáo de professores, por meio do Decreto 
no 6.755, de janeiro de 2009, que instituiu a Política Nacional de Formação dos Profissionais do Magistério da Educação Básica, com o objetivo de organizar os planos estratégicos da formação inicial e continuada, acordados nos Fóruns Estaduais Permanentes de Apoio à Formação Docente de cada Estado e do Distrito Federal (BRZEZINSKI, 2010 apud ABDALLA, 2012), fundamentado na contribuição das Instituiçốes Públicas de Educação Superior (IPES) e institui a CAPES como responsável pela indução, fomento e avaliação dos cursos.

A Resolução CNE/CP no 1, de 11 de fevereiro de 2009, que estabelece as Diretrizes Operacionais para a implantação do Programa Emergencial de Segunda Licenciatura para Professores em exercício na educação básica pública foi um complemento das ações do PDE, em relação à formação de professores e assegura em seu Art. $2^{\circ}$ que o "[...] programa destina-se aos professores em exercício na educação básica pública há pelo menos três anos em área distinta da sua formação inicial" (BRASIL, 2009b). E, por meio da Portaria Normativa ${ }^{\circ}$ 9, de 30 de junho de 2009, o Plano Nacional de Formaçáo dos Professores da Educação Básica foi instituído no âmbito do Ministério da Educação.

No dia 6 de agosto de 2009, a LDBEN no 9.394/1996 foi alterada, merecendo destaque o Art. 61, que passou a definir o "profissional de educação", incluindo nessa "categoria" os profissionais com habilitação para lecionar da educação infantil ao ensino médio, os pedagogos habilitados em administração, planejamento, supervisão, inspeção e orientação educacional e os "portadores de diploma de curso técnico ou superior em área pedagógica ou afins habilitados" que atuam na área educacional. No dia 13 de outubro de 2009, é sancionada a Lei no 12.056 que acrescenta parágrafos ao Art. 62 da LDBEN, a saber:

$\$ 1^{\circ}$ - A União, o Distrito Federal, os Estados e os Municípios, em regime de colaboração, deverão promover a formação inicial, a continuada e a capacitação dos profissionais de magistério.

$\$ 2^{\circ}$ - A formação continuada e a capacitação dos profissionais de magistério poderão utilizar recursos e tecnologias de educação a distância.

$\$ 3^{\circ}$ - A formação inicial de profissionais de magistério dará preferência ao ensino presencial, subsidiariamente fazendo uso de recursos e tecnologias de educação a distância (BRASIL, 2009c). 
O caput do Art. 62, da Lei no 12.056/2009, refere-se à habilitação necessária para o professor da educação básica que engloba a educação infantil, o ensino fundamental e o ensino médio. A inserção dos três parágrafos pela referida Lei reforça a necessidade de investimento na formação do profissional da educação e obriga as instâncias federativas para a promoção da formação inicial e continuada, bem como a capacitação dos profissionais do magistério. Essa Lei prestigiou a modalidade de educaçáo a distância como ferramenta dessa formaçáo continuada e da capacitação desses professores, sendo que a formação inicial do professor deverá ser realizada, preferencialmente, no ensino presencial, e a educação a distância será como uma complementação e aperfeiçoamento profissional.

No Brasil, a Formação de Professores da Educação Básica é normatizada por meio da organização de documentos legais que se articulam para dar sustentação a uma política nacional que almeja não apenas a formação inicial mínima para o exercício do magistério nos diferentes níveis e modalidades da educação e do ensino, mas também a promoção da formação continuada para os profissionais do Magistério da Educação Básica, numa conjectura que caminha rumo à "equalização de oportunidades educacionais e padrão mínimo de qualidade do ensino" (BRASIL, 2008, grifo nosso).

Para atender a Diretriz XII do Plano de Metas, em 2009, o Governo Federal instituiu através do Decreto no 6.755/2009 a Política Nacional de Formação de Profissionais do Magistério da Educação Básica e disciplina a atuação da CAPES no fomento a programas de formaçáo inicial e continuada, e encaminha outras providências (BRASIL, 2009a). Dessa forma, esse Decreto dispóe em seu Art. $1^{\circ}$, parágrafo único

[...] fica instituída a Política Nacional de Formação de Profissionais do Magistério da Educação Básica, com a finalidade de organizar, em regime de colaboração entre a União, os Estados, o Distrito Federal e os Municípios, a formação inicial e continuada dos profissionais do magistério para as redes públicas da educação básica. $\mathrm{O}$ disposto no caput do Decreto será realizado na forma dos Artigos 61 a 67, da Lei no 9.394, de 20 de dezembro de 1996, e abrangerá as diferentes modalidades da educação básica.

Nesse cenário, as Instituições de Ensino Superior devem propor cursos que atendam às demandas regionais, tendo como suporte os Fóruns Estaduais Permanentes de Apoio à Formação Docente. 
Os Fóruns são órgãos colegiados que têm como finalidade organizar, também em regime de colaboração entre os entes federados, a formação inicial e continuada dos profissionais do magistério para as redes públicas da educação básica. Suas atribuiçōes são: elaborar e acompanhar planos estratégicos com base no diagnóstico e na identificação das necessidades de formação do magistério das redes públicas, apoiado no censo escolar da educação básica: articular ações, otimizar recursos e potencializar esforços em interação com os sistemas de ensino e instituições formadoras sediadas no estado (GATTI, 2011, p. 54).

Portanto, o regime de colaboraçáo previsto no caput do Artigo ora mencionado e, também, no Parágrafo 1º, do Art. 62, da Lei no 12.056/2009, que fora acrescido à Lei no 9.394/1996, o qual estabelece as Diretrizes e Bases da Educação Nacional e que trata especificamente da formação inicial e continuada, bem como da capacitação dos profissionais de Magistério, embasa também a política nacional de formação de professores, em conformidade com o que se encontra prescrito no Art. 2º, Inciso III, do Decreto 6.755/2009:

Art. 20 - São princípios da Política Nacional de Formação de Profissionais do Magistério da Educação Básica:

III - a colaboração constante entre os entes federados na consecução dos objetivos da Política Nacional de Formação de Profissionais do Magistério da Educação Básica, articulada entre o Ministério da Educação, as instituiçôes formadoras e os sistemas e Redes de ensino (BRASIL, 2009a).

$\mathrm{O}$ artigo exposto apresenta como um dos princípios desta política a colaboraçáo, evidenciando que o alcance dos objetivos propostos ocorrerá mediante a permanente articulação entre o Ministério da Educação, as instituiçóes formadoras e os sistemas e redes de ensino.

É inegável, portanto, que a Política Nacional de Formação de Profissionais do Magistério da Educação Básica (BRASIL, 2009a) pode ser considerada como uma alternativa para a correçáo dos desvios pertinentes à formação docente, buscando dirimir as desigualdades dessa área, baseando-se, sobretudo, nos seguintes princípios:

A articulação entre a teoria e a prática no processo de formação docente; a importância do projeto formativo, assegurando organicidade ao trabalho e garantindo sólida base teórica e 
interdisciplinar; e a importância do docente no processo educativo da escola e de sua valorização profissional, traduzida em políticas permanentes de estímulo à profissionalização, entre outros (BRASIL, 2009a, Art. 2o).

Dessa forma, o PARFOR (BRASIL, 2009a), criado pela Portaria Normativa no 9 do MEC, como forma mais visível de operacionalização dessa política, prevê organizar as demandas e ofertas dos cursos de formação inicial e continuada do país.

\section{Consideraçóes finais}

O PARFOR é uma política educacional significativa na formação dos professores, porém o processo burocrático pelo qual passam muitos professores ao se inscreverem na Plataforma Freire promove desânimo em meio à lentidão e a efetivação das matrículas desses profissionais, não lhes restando, muitas vezes, outra alternativa senão assistir a tudo de modo passivo. Inicialmente, os Estados e os Municípios identificam as demandas, em seguida estabelecem as Licenciaturas que seráo oferecidas, depois os Fóruns Estaduais são organizados para discussão quanto à oferta e à procura. Vale lembrar que o Secretário Estadual de Educaçáo, bem como um membro indicado pelo governo, os dirigentes das Instituições Públicas de Educação Superior - IPES, representantes do MEC e das secretarias municipais de Educação e profissionais do Magistério são indicados pela seccional da Confederação Nacional dos Trabalhadores em Educação - CNTE, desses Fóruns. Dessa forma, quando há um consenso, as vagas são disponibilizadas na Plataforma Freire para os professores em exercício optarem pelo curso que desejam, porém, ainda assim, precisam esperar que a Secretaria, seja Municipal ou Estadual, possa validar suas inscriçóes.

Ademais, além do processo burocrático, o PARFOR não apresenta uma logística organizada voltada para as necessidades específicas de determinadas localidades e isso desencadeia na disposiçáo de muitos cursos sem interessados e muitos interessados sem curso. É inegável, portanto, que mesmo com essas discrepâncias, o avanço na qualidade da formação superior no país ocorre por meio dos Programas e pelo esforço dos próprios professores na busca de preparo para o exercício da profissáo, 
que tentam conciliar, na medida do possível, seus respectivos horários de trabalho às suas formaçóes, sem se afastarem de suas funçóes. Afinal, aos estudantes do PARFOR é negada a possibilidade de afastar-se de suas atividades laborais para dedicar-se, exclusivamente, ao rendimento em sala, sem contar que a grande maioria dos participantes é composta por mulheres, significando, muitas vezes, uma tripla jornada imposta pela sociedade, que se desenvolve no âmbito familiar entre marido e filhos, entre outros, na perspectiva de melhor aprimoramento pessoal, profissional que, consequentemente, contribui para a melhoria da qualidade na Educação.

À luz das mudanças ocorridas em resposta aos debates promovidos pelos movimentos sociais, a década de 1990 foi avaliada como um período marcante para vislumbrar os profissionais da educaçáo enquanto referências essenciais para as transformaçôes sociais. Assim, melhorar o nível da educação, sobretudo da educação básica, é uma preocupação retratada nas políticas públicas para a educação brasileira que tem como foco a formaçáo e o desempenho dos professores para a melhoria de seus padrôes e da qualidade em todo sistema educacional, apesar das diferenças regionais serem consideradas marcantes (INEP, 2008).

O PARFOR como Política Nacional de Formação de Professores da rede pública é, portanto, uma iniciativa recente, considerada plausível e relevante para assegurar o que determina a LDBEN 9.394/1996, no tocante à formaçáo dos profissionais da educação, bem como para melhorar a qualidade da educação brasileira, uma vez que a educação é um organismo vivo, e o professor é a peça fundamental para o crescimento cultural, social e econômico da nação. No entanto, essa responsabilidade pelo êxito ou fracasso atribuída ao professor constitui-se como ação delicada e cruel, visto que o Governo lança as propostas de melhoria da educação fundamentadas nas necessidades econômicas vigentes, mas, muitas vezes, não oferece condiçôes favoráveis para a efetivação dessas propostas ou se esquiva de suas responsabilidades frente às demandas sociais.

Nesse viés, a CAPES estabeleceu como meta inicial até o ano de 2014 que o PARFOR deveria certificar 330.000 (trezentos e trinta mil) professores. Porém, apesar de seus esforços, não conseguiu cumprir com essa meta, haja vista que o tempo previsto para a conclusão dos cursos pelo PARFOR é de três anos e isso pode ser considerado como um critério embargador na concretização dessa meta. 
Ademais, pode-se perceber que este Plano, assim como outras políticas públicas voltadas para a educação brasileira que se destinam ao atendimento dos direitos fundamentais de todo cidadáo, apresenta descriçóes e limitaçóes marcantes quanto aos direitos e as garantias que podem contribuir e/ou afetar a qualidade da formaçáo desses profissionais, como as atribuiçóes dos parceiros que não são especificadas no Decreto, no 6.755/2009, dando vazão às várias interpretações e tomada de decisóes omissas e alheias às necessidades vitais dos envolvidos, principalmente, daqueles que precisam se deslocar de suas cidades para o local de destino de sua formação.

Dando continuidade às limitaçóes observadas, é pertinente registrar que as metas estabelecidas inicialmente no Plano divergem do contexto real, pois a lei da oferta e da demanda é solidificada mais como cursos ofertados nem sempre corresponde com os anseios dos profissionais em formação, ou seja, com a própria demanda e, como fora mencionado no parágrafo anterior, também não existem especificidades quanto às unidades articuladoras quanto à função de cada uma, gerando, sobretudo, lacunas ou brechas para que muitas prefeituras se isentem de suas responsabilidades, não oferecendo sequer condiçóes para que os professores possam frequentar as aulas presenciais, propiciando, com isso, transtornos financeiros e descontentamentos por parte dos protagonistas desse processo. Diante do exposto, faz-se necessária a reavaliaçáo dos princípios e dos objetivos propostos nesse Plano, de forma que estes sejam redimensionados e suscetíveis ao sucesso, já que esse Plano faz parte de uma ação inovadora da educação no Brasil.

Nesse contexto, observa-se que tanto a Política quanto o Plano Nacional de Formaçáo de Professores possuem aspectos que podem solidificar a formaçáo dos professores ou mesmo impedir essa solidificaçáo e, apesar de o MEC sinalizar que a Política de Formação de Professores se define como um procedimento que leva em consideração articulaçóes entre as esferas Federal, Estadual e Municipal, na verdade nota-se que suas ações estão fortemente atreladas ao Plano de Metas da Educação ou mais precisamente ao PDE.

Destarte, a Política de Formação de Professores vigente no Brasil é considerada como um canal favorável à formação cultural entre os profissionais da docência. Porém, nota-se a necessidade de estudos mais profundos acerca dessa temática com o propósito de aclarar e investigar se os princípios estabelecidos têm sido cumpridos, na íntegra, entre as instâncias Federal, Estadual e, principalmente, Municipal, pois assim, 
amplia-se a colaboração e o fortalecimento desse Plano tão importante para o professor em formação, enquanto profissional competente, responsável e comprometido com a docência e a transformação social.

Nesse contexto, corrobora-se com as ideias de Gatti e Barreto (2009) que defendem o PARFOR como uma iniciativa recente em pleno desenvolvimento e, apesar dos entraves burocráticos e econômicos erguidos desde a sua implementação, deve-se aguardar um pouco mais tempo para avaliá-lo de forma mais elaborada entre o que fora proposto no Decreto $\mathrm{n}^{\mathrm{o}}$ 6.755/2009 e a realidade observada no decorrer de sua execução. Contudo, não se pode deixar de evidenciar que o PARFOR tem sido uma oportunidade enriquecedora para os professores da rede pública de ensino, que além de apreenderem conhecimentos, também promovem mudanças de postura que contribuem para uma prática pedagógica exitosa, sendo, portanto, um instrumento a favor da educação pública de qualidade da naçâo brasileira.

Conclui-se, portanto, que a temática em questão se encontra num amplo processo de discussão nacional, o que possibilita afirmar o inacabamento deste estudo, visto que essa temática será focalizada e complementada em outros momentos pelas contribuiçóes de muitos pesquisadores.

\section{Referências}

ABDALLA, Maria de Fátima Barbosa. Políticas de formaçáo de professores: desafios e perspectivas. Collatio 11 abr-jun. CEMOrOc-Feusp/IJI - Universidade do Porto, 2012. Disponível em: <www.hottopos.com/collat11/23-32FatAbd.pdf> Acesso em: 13 de jun. 2013.

BRASIL. Lei de Diretrizes e Bases da Educaçáo Nacional. Lei Federal no 9.394/96. Brasília: Congresso Nacional, 1996.

. Rede Nacional de Formaçáo Continuada de Professores da Educaçáo Básica: orientações gerais. Brasília: MEC/SEB, 2005.

Política de Educação Especial na Perspectiva Inclusiva. Brasília: SEESP/MEC, 2008.

. Ministério da Educação. Decreto no 6.755/2009. Institui a Política

Nacional de Formação de Profissionais do Magistério da Educaçáo Básica, disciplina a atuação da Coordenação de Aperfeiçoamento de Pessoal de Nível Superior-CAPES no fomento a programas de formaçâo inicial e continuada, e dá outras providências. Brasília, 2009a. 
BRASIL. Ministério da Educação. Resoluçáo no 1/2009. Estabelece Diretrizes Operacionais para a implantação do Programa Emergencial de Segunda Licenciatura para Professores em exercício na Educação Básica Pública a ser coordenado pelo MEC em regime de colaboraçáo com os sistemas de ensino e realizado por instituições públicas de Educação Superior. Brasília, 2009 b.

. Lei $\mathbf{n}^{\circ} \mathbf{1 2 . 0 5 6}$, de 13 de outubro de 2009. Acrescentou parágrafos ao Art. 62 da Lei n 9.394, de 20 de dezembro de 1996. Brasília, 2009c.

. Lei no 12.796, de 4 de abril de 2013. Altera a Lei no 9.394, de 20 de dezembro de 1996, dispóe sobre a formação dos profissionais da educação e dá outras providências. Brasília, 2013. Disponível em: <http://www.planalto.gov. br/CCIVIL_03/_Ato2011-2014/2013/Lei/L12796.htm> Acesso em: 20 de jul. 2013.

FREIRE, Paulo. Pedagogia da autonomia: saberes necessários à prática educativa. 33. ed. São Paulo: Paz e Terra, 2006.

GATTI, Bernardete Angelina. Políticas docentes no Brasil: um estado da arte / Bernardete Angelina Gatti, Elba Siqueira de Sá Barretto e Marli Eliza Dalmazo de Afonso André. Brasília: UNESCO, 2011.

GATTI, Bernardete Angelina; BARRETO, Elba Siqueira de Sá (Coord.). Professores do Brasil: impasses e desafios. Brasília, DF: UNESCO, 2009.

LIBÂNEO, José Carlos; PIMENTA, Selma Garrido. Formação de profissionais da educação: visão crítica e perspectiva de mudança. In: Revista Educação e Sociedade. [online]. v. 20, no 68, p. 239-277, 1999. ISSN 0101-7330. Disponível em: <http://www.scielo.br/scielo.php?script=sci_pdf\&pid=S0101$73301999000300013 \& \operatorname{lng}=$ en\&nrm=iso\&tlng=pt> Acesso em: 13 de nov. 2013.

MARCONI, Marina de Andrade; LAKATOS, Eva Maria. Fundamentos de metodologia científica. 7. ed. São Paulo: Atlas, 2010. 